\title{
A CONCRETIZAÇÃO DO DIREITO FINANCEIRO: OS EFEITOS DO CONTINGENCIAMENTO NA EXECUÇÃO ORÇAMENTÁRIA
}

Dissertação de mestrado apresentada ao Departamento de Direito Econômico, Financeiro e Tributário da Faculdade de Direito da Universidade de São Paulo como exigência parcial para a obtenção do título de Mestre em Direito.

Área de Concentração: Direito Financeiro

Orientador: Professor Doutor Fernando Facury Scaff 


\section{AGRADECIMENTOS}

Agradeço ao meu orientador, Professor Fernando Facury Scaff, cuja contribuição foi imensa para este trabalho. Agredeço pela dedicada orientação e pelas profundas discussões que fizeram sempre minha visão se ampliar.

Aos demais professores do Departamento de Direito Econômico e Financeiro da Faculdade de Direito da Universidade de São Paulo, em especial ao Professor José Maurício Conti, não só pelas sugestões feitas a este trabalho, mas também pelos reiterados incentivos ao estudo do Direito Financeiro durante toda a pós-graduação.

À Professora Élida Graziane Pinto, pelas enormes contribuições dadas ao trabalho.

Aos demais professores, funcionários e alunos da Faculdade de Direito da Universidade de São Paulo, especialmente aos amigos da pós-graduação em Direito Financeiro, Michel Haber Neto, Gabriel Lochagin, Isabela Morbach, Matheus Carneiro e Alexandre Silveira.

A todos com quem convivi e convivo no Rivitti e Dias, onde me ensinaram os primeiros passos na advocacia, especialmente a Karem, Rivitti e Murilo, pelas enormes contribuições na minha formação como jurista.

Agradeço aos muitos amigos que passaram e ficaram, e que seguramente participaram de algum modo na minha formação. Àqueles que tornaram meu caminho mais fácil ao vir estudar em São Paulo, obrigado aos professores e amigos da DireitoGV. Àqueles que me mostraram que trabalhar em São Paulo também seria divertido, obrigado Uirá, Larissa, Camila, Vini e Gabriel. Àqueles que não me deixam esquecer dos mais importantes valores da vida: Ju, Dante, Ana, Caio, Lu e Javi (ao terreno!). E, por último, àqueles que não importa pra onde vai ou pra onde vorta, esses estão sempre: obrigado William, Leite, Bozo, Gordo, Du, Carlim, Mora, Loba, Mosca, Tim, Trogo, Pipi, Gu e Godoy (Uh! É Falcatrua!).

Agradeço à minha família, principalmente aos primos Bruno, pelos inúmeros finais de semana de companhia; e Tati e Brites, pelo apoio desde os primeiros tempos de São Paulo, obrigado pelo carinho especial que sempre tiveram por mim (espero retribuir um pouco ao Benjamim). À família que me acolheu, Maria Helena, Celso e Gu, obrigado pelo incentivo. Dedico também aos meus avós, vô Agenor (em memória) e Ba Wanda, cujas lições de vida me tornaram uma pessoa mais humana. 
Aos meus pais e à minha irmã, Américo, Regina e Marta, pelo amor e pelo apoio incondicional nas escolhas da vida, o Mestrado foi apenas mais uma etapa das muitas que me ajudaram a superar. Dedico a vocês minhas alegrias e vitórias.

Por último, ainda que as palavras não sejam suficientes, agradeço e dedico o trabalho e todo o meu amor a quem está ao meu lado em todos os momentos, me completando de todas as formas, ajudando inclusive com sugestões acadêmicas e até ouvindo os meus desabafos sobre o contingenciamento. E se eu aprendi bem o que é resiliência, sei que ciclos se encerram e se iniciam, mas o importante é ter você, seja você quem for, seja o que Deus quiser. Deborah, sem você nada disso teria começado. 


\section{RESUMO}

O presente trabalho visa investigar em que medida o contingenciamento (artigo $9^{\circ}$ da Lei de Responsabilidade Fiscal) tem sido aplicado fora de seus parâmetros jurídicos e, consequentemente, representado um obstáculo à concretização do Direito Financeiro. Por trás desse objetivo está a ideia de que, atualmente, o grande desafio do Direito Constitucional Financeiro é a sua concretização. O trabalho está estruturado em cinco capítulos. No primeiro capítulo, são estabelecidas as premissas: o que se entende por concretização do Direito Constitucional Financeiro e quais são os principais obstáculos para esta. Nessa linha, destaca-se, em primeiro lugar, que o Direito Financeiro está inserido em um novo paradigma, no qual o orçamento deve ser encarado como meio de dar efetividade à Constituição, como instrumento de implementação do Estado Democrático de Direito e dos direitos fundamentais. Em segundo lugar, discute-se a prática relativa aos instrumentos de flexibilização orçamentária e como esta representa, em larga medida, um entrave à concretização do Direito Financeiro. No segundo capítulo, adentra-se na análise do instrumento de flexibilização orçamentária objeto de estudo - o contingenciamento -, interpretando-se o artigo $9^{\circ}$ da Lei de Responsabilidade Fiscal. Delineados os principais aspectos da norma que prevê o contingenciamento, no terceiro capítulo passa-se a olhar para sua aplicação. A partir de uma revisão doutrinária e de um levantamento de dados da execução orçamentária federal dos anos de 2010 a 2013, verifica-se em que medida há uma prática relativa ao contingenciamento fora dos parâmetros jurídicos. O quarto capítulo aponta para os efeitos do contingenciamento na execução do orçamento sob quatro perspectivas: (i) da realização de políticas públicas e consolidação de direitos sociais, (ii) do planejamento, (iii) da transparência e (iv) da legitimidade democrática do gasto público. Por meio dessa análise, além de reforçar as considerações do capítulo anterior, é possível configurar que a prática do contingenciamento tem sido um obstáculo à concretização do Direito Financeiro no Brasil. Por último, no quinto capítulo, apresentaram-se algumas propostas para o controle do contingenciamento no âmbito do Tribunal de Contas, do Poder Legislativo e do Poder Judiciário, verificando-se que é possível um controle jurídico do contingenciamento que, consequentemente, permita uma maior concretização do Direito Financeiro.

Palavras-chave: Direito Financeiro. Execução orçamentária. Contingenciamento. 


\begin{abstract}
The present study aims to investigate if the budgetary curtailment (Article 9 of the Fiscal Responsibility Law) has been applied according to its legal rules and if it represents an obstacle to the achievement of the Brazilian Public Finance Law. The thesis is structured in five chapters. The first chapter establishes two premises: the meaning of achieving the Public Finance Law and the main obstacles for it. We assume that the Public Finance Law is inserted into a new paradigm, in which the budget should be seen as a way to give effectiveness to the Constitution and as an instrument for implementing democratic rules and fundamental rights. We also discuss the practice regarding the flexibility instruments and how they can be an obstacle to the Public Finance Law achievement. In the second chapter, we analyse the budgetary curtailment regulation, specifically the article 9 of the Fiscal Responsibility Law. The third chapter looks to the use of the curtailment in the federal budget execution. From a doctrinal review and from a data collection of 2010-2013 federal budget execution, we demonstrate that there is an illegal use of the curtailments. The fourth chapter points out to the effects of curtailment in budget execution from four perspectives: (i) the accomplishment of public policies, (ii) the budget planning, (iii) the fiscal transparency and (iv) the democratic legitimacy of public expenditure. By this analysis, we conclude that the use of the curtailment in the federal budget execution has been an obstacle to the achievement of the Public Finance Law in Brazil. Finally, the fifth chapter presents some proposals for controlling the budget curtailment within the Federal Court of Accounts, the Legislative and the Judiciary. We verify that it is possible a legal control of the budget curtailment to strengthen the achievement of Public Finance Law.
\end{abstract}

Keywords: Public Finance Law. Budget execution. Budgetary curtailment. 


\section{LISTA DE TABELAS}

Tabela 1: Dados comparativos entre os Decretos de Contingenciamento editados no exercício de 2010, contendo, por órgão, (i) as despesas não obrigatórias ("outras despesas”) fixadas na Lei Orçamentária (acrescida de créditos adicionais), (ii) as despesas não obrigatórias ("outras despesas") disponíveis, conforme limites de empenho e movimentação financeira, e (iii) o percentual de disponibilidade das despesas não obrigatórias (“outras despesas”) em relação ao fixado em lei

Tabela 2: Evolução (ampliação ou redução) dos limites de empenho e movimentação financeira indicados para o Executivo pelo Relatório de Avaliação Bimestral em 2010

Tabela 3: Dados da Execução Orçamentária das despesas discricionárias em 2010, contendo, por órgão, (i) percentual executado (metodologia do Siga Brasil); (ii) \% empenhado/liquidado (em relação ao autorizado); (iii) percentual pago em relação ao empenhado/liquidado; e (iv) percentual pago em relação ao autorizado. 103

Tabela 4: Execução de Receitas do exercício de 2010, indicando, por tipo, (i) a receita prevista, (ii) a receita arrecadada, e (iii) o percentual arrecadado em relação ao previsto. 105

Tabela 5: Dados comparativos entre os Decretos de Contingenciamento editados no exercício de 2011, contendo, por órgão, (i) as despesas não obrigatórias (“outras despesas”) fixadas na Lei Orçamentária (acrescida de créditos adicionais), (ii) as despesas não obrigatórias ("outras despesas") disponíveis, conforme limites de empenho e movimentação financeira, e (iii) o percentual de disponibilidade das despesas não obrigatórias ("outras despesas") em relação ao fixado em lei

Tabela 6: Evolução (ampliação ou redução) dos limites de empenho e movimentação financeira indicados para o Executivo pelo Relatório de Avaliação Bimestral em 2011

Tabela 7: Dados da Execução Orçamentária das despesas discricionárias em 2011, contendo, por órgão, (i) percentual executado (metodologia do Siga Brasil); (ii) \% empenhado/liquidado (em relação ao autorizado); (iii) percentual pago em relação ao empenhado/liquidado; e (iv) percentual pago em relação ao autorizado. 
Tabela 8: Execução de Receitas do exercício de 2011, indicando, por tipo, (i) a receita prevista, (ii) a receita arrecadada, e (iii) o percentual arrecadado em relação ao previsto.

Tabela 9: Dados comparativos entre os Decretos de Contingenciamento editados no exercício de 2012, contendo, por órgão, (i) as despesas não obrigatórias (“outras despesas”) fixadas na Lei Orçamentária (acrescida de créditos adicionais), (ii) as despesas não obrigatórias ("outras despesas") disponíveis, conforme limites de empenho e movimentação financeira, e (iii) o percentual de disponibilidade das despesas não obrigatórias (“outras despesas”) em relação ao fixado em lei. 112

Tabela 10: Evolução (ampliação ou redução) dos limites de empenho e movimentação financeira indicados para o Executivo pelo Relatório de Avaliação Bimestral em 2012

Tabela 11: Dados da Execução Orçamentária das despesas discricionárias em 2012, contendo, por órgão, (i) percentual executado (metodologia do Siga Brasil); (ii) \% empenhado/liquidado (em relação ao autorizado); (iii) percentual pago em relação ao empenhado/liquidado; e (iv) percentual pago em relação ao autorizado. 115

Tabela 12: Execução de Receitas do exercício de 2012, indicando, por tipo, (i) a receita prevista, (ii) a receita arrecadada, e (iii) o percentual arrecadado em relação ao previsto.

Tabela 13: Dados comparativos entre os Decretos de Contingenciamento editados no exercício de 2013, contendo, por órgão, (i) as despesas não obrigatórias (“outras despesas”) fixadas na Lei Orçamentária (acrescida de créditos adicionais), (ii) as despesas não obrigatórias ("outras despesas") disponíveis, conforme limites de empenho e movimentação financeira, e (iii) o percentual de disponibilidade das despesas não obrigatórias (“outras despesas”) em relação ao fixado em lei. 118

Tabela 14: Evolução (ampliação ou redução) dos limites de empenho e movimentação financeira indicados para o Executivo pelo Relatório de Avaliação Bimestral em 2013

Tabela 15: Dados da Execução Orçamentária das despesas discricionárias em 2013, contendo, por órgão, (i) percentual executado (metodologia do Siga Brasil); (ii) \% empenhado/liquidado (em relação ao autorizado); (iii) percentual pago em relação ao empenhado/liquidado; e (iv) percentual pago em relação ao autorizado. 
Tabela 16: Execução de Receitas do exercício de 2013, indicando, por tipo, (i) a receita prevista, (ii) a receita arrecadada, e (iii) o percentual arrecadado em relação ao previsto.

Tabela 17. Total de receita arrecadada em relação ao previsto nos anos de 2010 a 2013

Tabela 18. Evolução dos percentuais de execução, empenho e pagamento das despesas discricionárias do Executivo nos anos de 2010 a 2013 


\section{LISTA DE FIGURAS}

Figura 1. Comparação entre percentual total arrecadado de receita e percentual executado e pago das despesas discricionárias do Executivo, nos anos de 2010 a 2013 (elaborada pelo

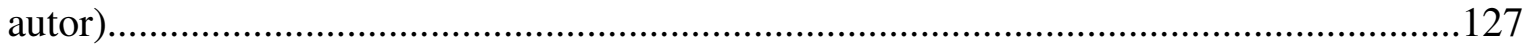




\section{SUMÁRIO}

\section{A CONCRETIZAÇÃO DO DIREITO FINANCEIRO E OS INSTRUMENTOS DE FLEXIBILIZAÇÃO ORÇAMENTÁRIA

1.1. Considerações iniciais sobre a concretização constitucional no âmbito do Direito

Financeiro.

1.2. Um novo paradigma para o Direito Financeiro a partir dos direitos

fundamentais.

1.3. Os conflitos de interesses, paixões e dominação e a concretização do Direito

Financeiro.

1.4. Os instrumentos de flexibilização orçamentária e a concretização do Direito

Financeiro.....

1.4.1. Reserva de contingência .45

1.4.2. Margem de remanejamento 47

1.4.3. Abertura de créditos adicionais 48

1.4.4. Desvinculação de receitas e tredestinação de gastos mínimos obrigatórios. .50

\section{ASPECTOS TEÓRICOS DO CONTINGENCIAMENTO: ANÁLISE DO} ARTIGO 9 DA LEI DE RESPONSABILIDADE FISCAL .56

2.1. Aspectos introdutórios: do planejamento à execução orçamentária .56

2.2. O antigo debate sobre a natureza e os efeitos da lei orçamentária: lei formal vs. lei material e orçamento autorizativo $v s$. orçamento impositivo 60

2.3. O Contingenciamento e seus requisitos: $\operatorname{artigo} 9^{\circ}$ da Lei de Responsabilidade Fiscal

2.3.1. O risco de não realização das receitas: o caput do artigo $9^{\circ}$ da Lei de Responsabilidade Fiscal

2.3.2. O contingenciamento sob a perspectiva do ato administrativo: motivo, motivação e finalidade do ato

2.3.3. Restabelecimento de receita e retomada proporcional da execução: $\S 1^{\circ}$ do artigo $9^{\circ}$ da Lei de Responsabilidade Fiscal 
2.3.4. A proteção das obrigações legais e constitucionais: $\S 2^{\circ}$ do $\operatorname{artigo} 9^{\circ}$ da Lei de

Responsabilidade Fiscal

2.3.5. O contingenciamento e o conflito entre os Poderes: $\S 3^{\circ}$ do artigo $9^{\circ}$ da Lei de

Responsabilidade Fiscal

2.3.6. Avaliação do cumprimento de metas: $\S 4^{\circ}$ e $\S 5^{\circ}$ do artigo $9^{\circ}$ da Lei de

Responsabilidade Fiscal 86

\section{A PRÁTICA DO CONTINGENCIAMENTO: ANÁLISE DE DADOS NO ÂMBITO DO ORÇAMENTO FEDERAL}

3.1. Considerações iniciais sobre a prática do contingenciamento: as críticas da doutrina

e os apontamentos dos meios de comunicação 88

3.2. Metodologia e análise dos dados sobre o contingenciamento .94

3.2.1. Exercício de 2010 99

3.2.2. Exercício de 2011 106

3.2.3. Exercício de 2012 112

3.2.4. Exercício de 2013 117

3.3. Considerações gerais sobre os dados apresentados.

3.4. Execução orçamentária e superavit primário 128

\section{O CONTINGENCIAMENTO E OS EFEITOS NA EXECUÇÃO DO GASTO} PÚBLICO

4.1. Considerações iniciais sobre os efeitos selecionados.

4.2. Os efeitos do contingenciamento na realização das políticas públicas e na consolidação dos direitos sociais

4.3. Os efeitos do contingenciamento no planejamento do gasto público

4.4. Os efeitos do contingenciamento na transparência do gasto público.

4.5 Os efeitos do contingenciamento na legitimidade democrática do gasto público. 
5.2. O Controle pelo Tribunal de Contas

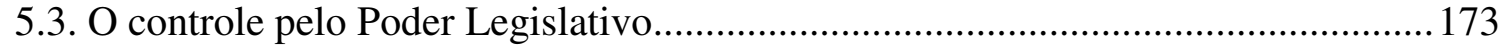

5.4. O Controle pelo Poder Judiciário ........................................................................ 178

5.4.1. Breve revisão da relação entre Judiciário e orçamento .................................... 178

5.4.2. Controle judicial do contingenciamento: análise de casos .............................. 186

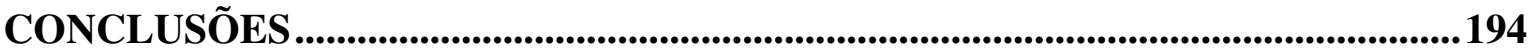

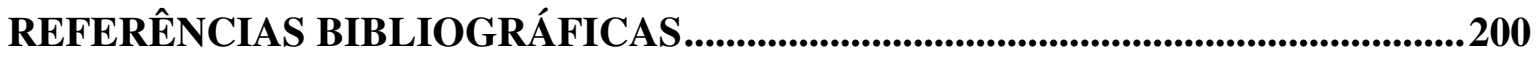




\section{INTRODUÇÃO}

Em um passado recente, a inflação descontrolada, a ausência de mecanismos democráticos e a falta de regulamentação traziam um cenário precário para o desenvolvimento do Direito Financeiro. Discussões sobre execução orçamentária, planejamento, qualidade, transparência, controle e legitimidade do gasto público se mostravam secundárias frente à instabilidade política e econômica.

O retorno da democracia a partir da Constituição de 1988 e a estabilização econômica alcançada a partir do final dos anos 90 foram acompanhados por inovações normativas que buscaram permitir maior acompanhamento e controle do gasto público, além de pretender lhe conferir transparência, planejamento, e legitimidade democrática. A implementação de tais características passou não apenas a ser desejada, mas obrigatória.

Nesse contexto, cresceram os estudos no âmbito do Direito Financeiro e das Finanças Públicas, que agora se encontram diante de novos problemas: desenvolvido o arcabouço institucional (se não de forma suficiente, relativamente avançada), os desafios passam a ser, cada vez mais, implementar os objetivos e as determinações previstas na Constituição e nas leis, aplicar as normas adequadamente, atribuir eficácia ao Direito Financeiro, concretizá-lo.

É diante desses novos desafios que se insere o presente trabalho, o qual pretende analisar um dos mecanismos mais influentes no processo de concretização do Direito Financeiro: o contingenciamento.

O contingenciamento (ou limitação de empenho e de movimentação financeira) é um instrumento de flexibilização orçamentária que, durante o procedimento de execução do orçamento, permite ao gestor público ajustar a arrecadação de receitas à execução das despesas. Embora seja um mecanismo essencial nesse procedimento, sua utilização impede que o gasto público atinja sua fase final, o que, por vezes, ocorre à margem da lei. $\mathrm{O}$ contingenciamento tem sido utilizado de forma bastante frequente pelos governos brasileiros, o que tem levantando suspeitas da doutrina (e também dos meios de comunicação) sobre a sua correta aplicação. A reiterada utilização do contingenciamento nos últimos anos, sua centralidade dentro da execução orçamentária e as críticas doutrinárias sobre os seus efeitos no gasto público indicam a relevância do tema, bem como sua atualidade. 
Nessa linha, pretende-se analisar dados que permitam verificar se a aplicação do contingenciamento tem respeitado seus pressupostos e parâmetros jurídicos, tema que tem gerado preocupação em analistas e estudiosos das finanças públicas. Propõe-se, ainda, verificar os efeitos da utilização do contingenciamento sobre diversos aspectos da execução e da própria elaboração orçamentária, bem como a possibilidade de controle sobre sua aplicação.

Considerando os objetivos apontados, o curso do presente trabalho passa por quatro questões a seguir detalhadas.

Primeiro, é necessário que se faça uma análise da norma, de modo a verificar (01) quais os parâmetros jurídicos do contingenciamento?

Olha-se principalmente para o artigo $9^{\circ}$ da Lei de Responsabilidade Fiscal, que dispõe sobre o contingenciamento.

Delineada a interpretação da norma, questiona-se (02) o contingenciamento, tal como aplicado nos últimos anos, tem respeitado os seus parâmetros jurídicos?

A hipótese adotada é que esse instrumento de flexibilização orçamentária, embora devesse se configurar como mecanismo de exceção, tem se tornado regra e, ademais, tem sido utilizado sem a observância das normas que o regulamentam. Desde já, aponta-se que tal hipótese se fundamenta nas suspeitas da doutrina, adiante apresentadas, as quais serão comprovadas a partir de dados da própria execução orçamentária.

Avançando na análise, e verificados os aspectos quantitativos sobre o contingenciamento, surge a terceira questão: (03) quais os efeitos do contingenciamento na execução do gasto público?

Essas questões estão intrinsecamente relacionadas, vez que a demonstração de que o contingenciamento está sendo aplicado fora de seus parâmetros jurídicos é reforçada pelos efeitos maléficos gerados na execução orçamentária e, também, em alguns aspectos da própria elaboração do orçamento. $\mathrm{Na}$ análise da terceira questão proposta, será necessário um corte metodológico, de modo a eleger alguns dos efeitos causados pelo contingenciamento no gasto público, os quais, conforme justificativas adiante, entende-se como os mais pertinentes às premissas e aos objetivos do trabalho.

Por fim, com o intuito de acrescer um viés propositivo ao trabalho, questiona-se: (04) é possível o controle jurídico do contingenciamento?

Quanto à quarta questão, não se contesta a legalidade ou constitucionalidade da previsão normativa do contingenciamento (da norma em abstrato), ou ainda, da possibilidade de contingenciar. Busca-se, na verdade, questionar a prática relacionada ao 
contingenciamento, ou seja, se os decretos de execução orçamentária e de contingenciamento respeitam os parâmetros legais. Pretende-se, portanto, verificar em que medida os órgãos de controle - Tribunal de Contas, Legislativo e Judiciário -, têm atuado, ou poderiam atuar frente à aplicação do contingenciamento.

Esclarece-se que a análise do contingenciamento e de seus efeitos sobre o gasto público se insere, em última instância, dentro de um novo desafio enfrentado pelo Direito Financeiro a que se referiu inicialmente: sua concretização. Essa concretização está amparada pelo sistema de direitos fundamentais e pelo Estado Democrático de Direito estabelecidos na Constituição Federal de 1988, cujos objetivos, dentre outros, são: melhor planejamento, mais transparência e legitimidade democrática do gasto público; efetiva implementação de políticas públicas, concretização dos direitos fundamentais e da democracia; promoção do desenvolvimento social e institucional.

Se de um lado é relevante verificar os objetivos constitucionais relativos ao Direito Financeiro; de outra parte, cumpre também olhar para os obstáculos enfrentados pela sua concretização, dentro dos quais está inserida a prática do contingenciamento. É preciso investigar se a concretização do Direito Financeiro (e de seus objetivos) tem sido possível ou se, ao contrário, se tais objetivos têm sido submetidos exclusivamente aos fins políticos e econômicos, à manipulação excessiva dos governantes frente a outros valores que não aqueles elencados constitucionalmente. A premissa aqui é a de que uma maior concretização do Direito Financeiro passa também por uma melhor aplicação do contingenciamento, ou seja, uma aplicação dentro de seus limites e parâmetros jurídicos.

Em suma, o trabalho terá como eixo as seguintes grandes questões:

(01) Quais os parâmetros jurídicos do contingenciamento?

(02) O contingenciamento, tal como aplicado nos últimos anos, tem respeitado os seus parâmetros jurídicos?

(03) Quais os efeitos do contingenciamento, aplicado sem observância de parâmetros jurídicos, na execução do gasto público?

(04) É possível um controle jurídico da prática do contingenciamento?

Para cumprir com os objetivos propostos, organiza-se o trabalho em cinco capítulos.

No capítulo 01, serão fixadas duas premissas: primeira, o que se entende por concretização do Direito Financeiro, estabelecido constitucionalmente e inserido em um novo paradigma; segunda, quais são os obstáculos para a concretização do Direito Financeiro. Serão apresentados obstáculos de dois tipos: um relacionado aos conflitos de 
interesses intrínsecos à própria natureza humana e outro relacionado à aplicação dos instrumentos de flexibilização orçamentária. O contingenciamento está inserido nesse segundo obstáculo, e por ele o trabalho prossegue.

Fixadas as premissas, no capítulo 02 se adentra na análise do instrumento de flexibilização orçamentária objeto central do estudo - o contingenciamento -, com o objetivo de defini-lo e apresentar os parâmetros jurídicos a que se submete. No capítulo 02 interpreta-se o artigo $9^{\circ}$ da Lei de Responsabilidade Fiscal, justamente a norma que prevê a hipótese de contingenciamento. Nesse capítulo, traçam-se os limites para a aplicação do instituto (para os decretos de contingenciamento), os quais, se não observados, serão marcados pela ilegalidade e/ou inconstitucionalidade. Aqui se insere a primeira questão proposta: quais os parâmetros jurídicos do contingenciamento? De se esclarecer que a pretensão do estudo não é engessar a discussão orçamentária ao código "pode/não pode", mas traçar alguns contornos jurídicos necessários (e existentes) e do qual a prática do contingenciamento está afastada. Da mesma forma, não se tem por objetivo questionar a constitucionalidade do artigo $9^{\circ}$ da Lei de Responsabilidade Fiscal, ou seja, do contingenciamento em abstrato, mas de sua prática.

No capítulo 03, serão apontadas, primeiramente, as considerações da doutrina e dos meios de comunicação sobre a prática do contingenciamento; e, em segundo lugar, será feita uma análise dos dados acerca da utilização do contingenciamento nos últimos anos, adotando-se uma série de quatro anos - 2010 a 2013. Nesse momento, inicia-se a análise da segunda questão proposta: o contingenciamento, tal como aplicado nos últimos anos, tem respeitado os seus parâmetros jurídicos?

No capítulo 04, pretende-se apreciar os efeitos do contingenciamento na execução do orçamento e no gasto público, sob as seguintes perspectivas: (i) da realização de políticas públicas e consolidação de direitos sociais, (ii) do planejamento, (iii) da transparência e (iv) da legitimidade democrática. Este capítulo tem por base a terceira pergunta: quais os efeitos (especialmente qualitativos) do contingenciamento na execução do gasto público? As análises obtidas nesse capítulo reforçam e confirmam as respostas obtidas no capítulo anterior (primordialmente sobre efeitos quantitativos).

Por último, no capítulo 05, busca-se apresentar propostas para o controle do contingenciamento no âmbito do Tribunal de Contas, do Poder Legislativo e do Poder Judiciário. Propostas não necessariamente voltadas à alteração das normas, mas principalmente sobre a aplicação das normas já existentes. Insere-se aqui a quarta questão: é possível um controle jurídico da prática do contingenciamento? 
Ressalta-se que o trabalho tem por intuito pensar em que medida pode o Direito Financeiro, a partir da melhor aplicação de seus institutos, servir como um vetor de mudança social, em especial, implementando os objetivos fundamentais da República Federativa do Brasil, previstos no artigo $3^{\circ}$ da Constituição de 1988. 


\section{A CONCRETIZAÇÃO DO DIREITO FINANCEIRO E OS INSTRUMENTOS DE FLEXIBILIZAÇÃO ORÇAMENTÁRIA}

\subsection{Considerações iniciais sobre a concretização constitucional no âmbito do Direito Financeiro}

A Constituição Federal de 1988 é classificada pela doutrina como "Constituição diretiva ou programática" ou, ainda, como "Constituição social ou dirigente"2, especialmente porque nela se concebe um extenso rol de direitos sociais (ou direitos fundamentais de $2^{\mathrm{a}}$ geração), a previsão de uma igualdade substancial e a exigência por uma atuação positiva do Estado na implementação de políticas públicas.

Conforme explicita Eros Grau, as Constituições diretivas ou programáticas não são compreendidas como um “"mero instrumento de governo', mas, além disso, enunciam diretrizes, programas e fins a serem pelo Estado e pela sociedade realizados" ${ }^{3}$. Ou, ainda, como esclarece Canotilho, "regras e princípios constitucionais valem como 'lei': o direito constitucional é direito positivo",

A Constituição traz, dentre as disposições de seu texto, um "conteúdo econômico", visando a "implementação de um Estado Democrático de Direito, em conformidade com o artigo $1^{\circ}$ da Constituição de 1988, razão de existir de nossa República”. Incorpora uma concepção do Direito não apenas como garantidor das liberdades individuais, mas também como implementador de políticas públicas nas áreas sociais, educacionais, previdenciárias, ambientais, dentre outras ${ }^{6}$.

\footnotetext{
${ }^{1}$ GRAU, Eros Roberto. A ordem econômica na Constituição de 1988, 10ª ed. São Paulo; Malheiros, 2005, p. 78.

${ }^{2}$ TAVARES, André Ramos. Curso de direito constitucional. São Paulo: Saraiva, 2002, p. 74

${ }^{3}$ GRAU, Eros Roberto. A ordem econômica na Constituição de 1988, 10ª ed. São Paulo; Malheiros, 2005, p. 78.

${ }^{4}$ CAnOtilho, J. J. Gomes. Direito Constitucional e Teoria da Constituição. $7^{a}$ ed. Coimbra: Almedina, 2003, p. 1.176. Essa concepção de Constituição não significa, por certo, de que é dispensável uma "densificação" das normas constitucionais através de leis, como ressalva o próprio Canotilho quando da análise da vinculação do legislador pela Constituição dirigente. O mesmo autor conclui: "a concretização das imposições constitucionais é, no plano jurídico, um processo e não um acto, é uma sequência de actualização e não um estampido isolado; no plano político, ela é uma luta democrática quotidianamente renovada no sentido da realização dos fins e tarefas constitucionais" (CANOTILHO, J. J. Gomes. Constituição Dirigente e vinculação do legislador. $2^{\mathrm{a}}$ ed. Coimbra: Coimbra Editora, 2001, p. 480).

${ }^{5}$ SCAFF, Fernando Facury. Constituição Econômica Brasileira em seus 15 anos. Revista de Direito Público da Economia - RDPE, Belo Horizonte, v. 3, jul / set, 2003, p. 178.

6 “A Constituição Federal surgiu como um instrumento de defesa do cidadão contra o poderio do Estado, mas também como um instrumento construtor de uma nova cidadania, implementadora de políticas públicas que permitissem a realização de diversas finalidades estabelecidas na Carta: sociais, educacionais, previdenciárias, ambientais, de proteção às minorias, etc." (SCAFF, Fernando Facury. Constituição
} 
Nesse contexto, para a implementação dos direitos fundamentais (mormente dos direitos sociais) e dos preceitos do Estado Democrático de Direito, deve-se buscar a concretização das normas constitucionais ${ }^{7}$.

Adota-se aqui o termo concretização que, conforme define Carlos Antonio de Almeida Melo, expressa "a ação de passar ao concreto da vida sensível, isto é, na transição da norma-posição ou do princípio implícito para a realidade social concreta" ${ }^{\Perp}$. Entretanto, diversas são as denominações dadas pela doutrina para o que se expõe: concretização, concreção, aplicabilidade, eficácia normativa, dentre outras.

Canotilho utiliza tanto o termo concretização quanto o termo "realização constitucional". O primeiro quando menciona aa "concretização das imposições constitucionais", dirigidas sobretudo ao legislador e que visam à conformação jurídica de situações de fato, regulamentação de questões específicas, criação de pressupostos para evolução do regime constitucional e adaptação de leis antigas a novos princípios da lei fundamental. Utiliza o último termo (realização constitucional) para indicar o fenômeno de tornar juridicamente eficazes as normas constitucionais, aduzindo ser essa tarefa de todos os órgãos, na atividade legiferante, administrativa e judicial, e também de todos os cidadãos, que fundamentam na Constituição, ainda que indiretamente, seus direitos e deveres 9 .

Paulo Bonavides fala em aplicação constitucional, apontando que "o grande problema do momento constitucional brasileiro é o de aplicar a Constituição"10 , também

Econômica Brasileira em seus 15 anos. Revista de Direito Público da Economia - RDPE, Belo Horizonte, v. 3, jul / set, 2003, p. 62).

${ }^{7}$ SCAFF, Fernando Facury. Constituição Econômica Brasileira em seus 15 anos. Revista de Direito Público da Economia - RDPE, Belo Horizonte, v. 3, jul / set, 2003, p. 195.

${ }^{8}$ MELO, Carlos Antonio de Almeida. Mecanismos de proteção e concretização constitucional: proposta de uma ação de concretização da Constituição. In SCAFF, Fernando Facury (org.). Constitucionalizando Direitos: 15 anos da Constituição Brasileira de 1988. Rio de Janeiro: Renovar, 2003, p. 45.

9 A definição de "concretização constitucional foi extraída de CANOTILHO, J. J. Gomes. Constituição Dirigente e vinculação do legislador. $2^{a}$ ed. Coimbra: Coimbra Editora, 2001, p. 480.

Já a definição de "realização constitucional" foi extraída de CANOTILHO, J. J. Gomes. Direito Constitucional e Teoria da Constituição. $7^{\mathrm{a}}$ ed. Coimbra: Almedina, 2003, pp. 1.200/1.201. Na mesma obra, o autor português afirma que concretizar a constituição significa densificar regras e princípios constitucionais: "a concretização das normas constitucionais implica um processo que vai do texto da norma (do seu enunciado) para uma norma concreta - norma jurídica - que, por sua vez, será apenas um resultado intermédio, pois só com a descoberta da norma de decisão para a solução dos casos jurídico-constitucionais teremos o resultado final da concretização".

${ }^{10}$ BONAVIDES, Paulo. Curso de Direito Constitucional. $25^{\mathrm{a}}$ ed. São Paulo: Malheiros, 2010, p. 381 . Diz o autor: "concretizar o texto, introduzi-lo na realidade nacional, eis um verdadeiro desafio das Constituições brasileiras, desde os primórdios da República (...) Até hoje no Brasil a preocupação maior tem sido, após a queda de cada ditadura, apenas legitimar um chefe de governo, um Presidente da República, um caudilho, um aventureiro político; jamais um sistema de poder, uma pauta de regras e princípios, uma ordem jurídica moderna ou uma nova estrutura da economia. (Curso de Direito Constitucional. 25 a ed. São Paulo: Malheiros, 2010, p. 381). 
fazendo referência às dificuldades de trazer para a realidade as determinações constitucionais. Esse também o problema que se verifica no âmbito do Direito Financeiro e que se discute neste trabalho.

Em sentido semelhante, Fernando Facury Scaff fala em "luta pela concreção da Constituição de 1988", apontando que esta começou bastante cedo, com um ponto a favor daqueles que se posicionaram por sua inaplicabilidade. $\mathrm{O}$ autor exemplifica a falta de concreção da Constituição citando a previsão dos $12 \%$ de juros anuais, que sobreviveu como um fantasma até ser revogada por uma Emenda Constitucional. Cita também a utilização das medidas provisórias, cuja aplicação equivocada e exagerada ajudou a conservar a ordem existente, contrariando assim os próprios objetivos constitucionais ${ }^{11}$.

Encontram-se, ainda, distinções entre os sentidos dos termos eficácia, aplicação e efetividade, como bem relata Ingo Sarlet. O autor aponta uma interessante conclusão, que será seguida no presente trabalho: "as noções de aplicabilidade e eficácia podem ser consideradas, na verdade, duas faces da moeda, na medida em que uma norma será eficaz (no sentido jurídico) por ser aplicável e na medida de sua aplicabilidade”. Ou seja, trata-se a eficácia como fenômeno jurídico e social. Do ponto de vista jurídico, é a aptidão para ser aplicada aos casos concretos e gerar efeitos. Do ponto de vista social, também denominado efetividade, é a decisão pela efetiva aplicação da norma e o resultado concreto decorrente dessa aplicação ${ }^{12}$.

Pensa-se, portanto, na concretização da Constituição como forma de conferir às suas normas maior eficácia, tanto da perspectiva de sua aplicabilidade (aptidão para ser aplicada) a casos concretos, quanto do ponto de vista dos resultados práticos decorrentes dessa aplicação.

Restringindo a análise da concretização da Constituição ao âmbito do Direito Financeiro, essa compreende a utilização do orçamento como mecanismo de implementação dos direitos sociais, como meio de fortalecimento dos preceitos democráticos (garantindo transparência e legitimidade democrática ao gasto público) e também como forma de imprimir maior planejamento ao gasto. Compreende, ainda, a observância da separação de Poderes e o respeito ao federalismo fiscal. Alcançar esses objetivos tem como premissa a concretização do Direito Financeiro, cuja matriz está na

\footnotetext{
${ }^{11}$ SCAFF, Fernando Facury. Constituição Econômica Brasileira em seus 15 anos. Revista de Direito Público da Economia - RDPE, Belo Horizonte, v. 3, jul / set, 2003, p. 196.

12 SARLET, Ingo Wolfgang. A Eficácia dos Direitos Fundamentais. Porto Alegre: Livraria do Advogado, 2001, p. 215.
} 
Constituição. Sobre os renovados desafios do Direito Financeiro, Heleno Taveira Torres indica:

Para o Direito Financeiro convergem renovados desafios. Ele deve propor soluções para as grandes causas nacionais, como é o federalismo, o desenvolvimento equilibrado e a redução das desigualdades regionais e sociais, superar mitos, como ainda persistem aqueles da redução do Estado, integrar-se com os mais elevados temas do constitucionalismo, cada vez mais, assegurar meios para a internacionalização e fortalecimento do Estado, nas questões entre regionalismo e custeio da sua atuação internacional, bem como preocupar-se com o atendimento das demandas intergeracionais, aquelas do porvir, das futuras gerações. Ao mesmo tempo, deve servir como instrumento eficiente para a concretização de direitos e liberdades fundamentais, assistir aos desvalidos, garantir o compromisso nacional com educação e saúde de qualidade, conferir segurança jurídica para permitir que precatórios de pequeno valor ou custeios das necessidades vitais sejam atendidos com a mesma agilidade que os grandes contratos públicos. E que todos os controles financeiros, internos e externos, possam permitir que os princípios da economicidade e eficiência prevaleçam em todos os contratos e na administração dos gastos públicos, com eliminação da corrupção e das gestões perdulárias em todos os níveis de governo. ${ }^{13}$

A partir dessas considerações, é possível inserir o objeto deste trabalho na discussão sobre a concretização do Direito Financeiro. Tem-se como hipótese a ser verificada que o contingenciamento, da forma como utilizado, tem trazido grandes prejuízos à concretização dos objetivos constitucionais. Trata-se de mecanismo cuja aplicação fora dos limites jurídicos (adiante descritos) provoca distorções em diversos âmbitos do Direito Financeiro: prejudica a transparência, distorce o planejamento, reduz a legitimidade democrática e a possibilidade de controle do gasto público. Dito de outro modo, a utilização do contingenciamento sem observância de seus parâmetros jurídicos tem permitido a apropriação do orçamento por valores e interesses que não aqueles determinados pela Constituição. É dizer que as normas de Direito Financeiro têm sido afetadas por objetivos políticos, econômicos e individuais, transformando a "Constituição dirigente e social" em uma "Constituição simbólica".

A prática relativa ao contingenciamento é um possível exemplo de “constitucionalização simbólica", conforme terminologia utilizada por Marcelo Neves ${ }^{14}$. Partindo do pressuposto de que "é função jurídica da Constituição institucionalizar os direitos fundamentais e o Estado de Bem-estar social", sem restrições ao texto

\footnotetext{
${ }^{13}$ TORRES, Heleno Taveira. Teoria da Constituição Financeira. Tese apresentada ao Concurso de Títulos e Provas para o cargo de Professor Titular de Direito Financeiro. Faculdade de Direito da Universidade de São Paulo. São Paulo, 2014, p. 25.

${ }^{14}$ NEVES, Marcelo. A Constitucionalização Simbólica. São Paulo: WMF Martins Fontes, 2007.
} 
constitucional, no qual tanto os direitos individuais, sociais e coletivos quanto os procedimentos para sua prestação são previstos de forma suficientemente abrangente, há um problema no plano da concretização constitucional, uma vez que "a prática política e o contexto social favorecem uma concretização restrita e excludente dos dispositivos constitucionais". Os valores políticos, econômicos e sociais, que não aqueles delineados pelo Direito, impedem uma maior força normativa da Constituição. Nas palavras de Marcelo Neves, o "bloqueio permanente e generalizado do código lícito/ilícito pelos códigos ter/não-ter (economia) e poder/não-poder (política) implica uma prática jurídicopolítica estatal e extra-estatal caracterizada pela ilegalidade" ${ }^{15}$.

É justamente o que se pretende demonstrar com o contingenciamento: na prática política, bloqueiam-se os parâmetros jurídicos, impondo-se o contingenciamento através de critérios unicamente políticos e econômicos, tendo como consequência uma concretização restrita da Constituição, justamente em sua função jurídica de institucionalizar direitos fundamentais e outros preceitos do Estado de Bem-estar social.

Em suma, a hipótese aqui apresentada sugere que várias normas constitucionais de Direito não são concretizadas em razão de justificativas políticas e econômicas, fora dos limites jurídicos impostos pela Constituição e por demais normas infraconstitucionais, o que ocorre de forma bastante frequente e intensa em decorrência da prática do contingenciamento, como inclusive já discute a doutrina que trata do tema, adiante estudada.

Utilizando-se, ainda, de outra denominação, trata-se em última instância de se verificar a "força normativa da Constituição" e demais normas jurídicas no âmbito do Direito Financeiro: qual sua capacidade de modificar a realidade política, econômica e social, e não simplesmente se submeter a ela? Nas palavras de Konrad Hesse, "a Constituição jurídica não configura apenas a expressão de uma dada realidade. Graças ao elemento normativo, ela ordena e conforma a realidade política e social (...) a Constituição

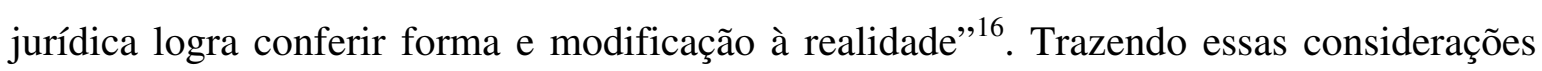
para o objeto de estudo, o entendimento que aqui se toma como premissa é que o Direito Financeiro deve impor rumo a maior concretização dos valores elegidos constitucionalmente, a partir de uma execução orçamentária mais adequada, reduzindo o

\footnotetext{
${ }^{15}$ NEVES, Marcelo. A Constitucionalização Simbólica. São Paulo: WMF Martins Fontes, 2007.

${ }^{16}$ HESSE, Konrad. A força normativa da Constituição. Trad. de Gilmar Ferreira Mendes. Porto Alegre: Sergio Antonio Fabris Editor, 1991 p. 24.
} 
âmbito de aplicação do contingenciamento aos seus limites jurídicos para, então, possibilitar maior conformação à realidade política e social.

De se ressaltar, por fim, que a concretização do Direito Financeiro não se limita à necessidade de se observar os procedimentos formais de elaboração e execução orçamentária. O orçamento não é mera peça contábil, tampouco apenas o instrumento de controle do "parlamento" sobre o "governante". Olha-se para o Direito Financeiro de forma mais ampla, com os renovados objetivos elencados constitucionalmente. Na linha do que escreve Alessandro Octaviani, "o espaço de imaginação institucional nas mãos do jurista comprometido com o direito financeiro para a superação do subdesenvolvimento, como se vê, é enorme: é o próprio espaço para a concretização da Constituição Federal"17.

Assim, para prosseguir na discussão, adota-se aqui a perspectiva de um Direito Financeiro substantivo e constitucional, visto sob um novo paradigma.

\subsection{Um novo paradigma para o Direito Financeiro a partir dos direitos fundamentais}

A partir de uma perspectiva histórica da teoria do Direito Financeiro, Horacio Corti aponta que, em um primeiro momento, prevaleceu uma visão clássica sobre o orçamento, centrada fundamentalmente em seus aspectos formais - competência e procedimentos do ciclo orçamentário, preparação, aprovação, execução, modificação e controle da lei orçamentária. Dentro dessa visão clássica, o orçamento é uma técnica que nasce com o Estado constitucional e liberal de Direito, através do qual se consolida a capacidade de decisão política dos parlamentos sobre os recursos públicos, antes dominados somente pelo "Executivo" (ou pelo monarca absolutista). Nesse sentido, a relação entre Executivo e Legislativo ocupa espaço central na problemática jurídica clássica do orçamento público, uma vez que suas funções principais eram o controle dos recursos públicos pelo Legislativo e a organização e planejamento pelo Executivo ${ }^{18}$.

Os elementos da visão clássica do orçamento, assim como os aspectos formais relativos à sua elaboração e execução, não devem ser abandonados no atual Estado

\footnotetext{
${ }^{17}$ OCTAVIANI. Alessandro. A bênção de Hamilton na semiperiferia: ordem econômico-social e os juros da dívida pública interna. In CONTI, José Maurício; SCAFF, Fernando Facury (coord.). Orçamentos Públicos e Direito Financeiro. São Paulo: Editora Revista dos Tribunais, 2011, p. 1.201.

${ }^{18}$ CORTI, Horacio. Derechos fundamentales y presupuesto publico. In CONTI, José Maurício; SCAFF, Fernando Facury (coord.). Orçamentos Públicos e Direito Financeiro. São Paulo: Editora Revista dos Tribunais, 2011, pp. 140-143.
} 
Democrático de Direito, inclusive são também objeto da presente análise. Porém, há que se reconhecer que essa visão de orçamento, voltada exclusivamente para o controle do Legislativo sobre o Executivo passa a ser insuficiente diante das novas configurações jurídicas, sociais e políticas. É por isso que deve o Direito Financeiro ser encarado dentro de um novo paradigma, com um aspecto inexistente no "paradigma clássico": "a relação entre a lei orçamentária e os direitos fundamentais" ${ }^{\prime 19}$.

Esse novo paradigma do Direito Financeiro tem como uma de suas premissas a constitucionalização das finanças públicas, movimento que é apontado por vários autores, como se demonstra a seguir.

André Castro Carvalho reconhece que "as finanças públicas começaram a ganhar traços constitucionais, mormente com o advento da segunda dimensão das garantias fundamentais e institucionais", momento a partir do qual o Estado passa a ter uma postura ativa na consecução desses direitos ${ }^{20}$. Reconhece o autor a existência de uma zona de intersecção entre Direito Financeiro e Direito Constitucional, denominada "Direito Constitucional Financeiro". Heleno Taveira Torres denomina de Constituição Financeira o resultado da constitucionalização do Direito Financeiro, a qual compreende a "parcela material de normas jurídicas integrantes do texto constitucional, composta pelos princípios fundamentais, as competências e os valores que regem a atividade financeira do Estado $(\ldots), 21$.

No mesmo sentido do que aqui se defende, Eduardo Bastos Furtado de Mendonça aponta como funções constitucionais na seara orçamentária não apenas o estabelecimento de regras formais sobre elaboração e execução, o que estaria inserido no paradigma clássico, mas também a interferência no próprio mérito das decisões orçamentárias - “a ordem constitucional não cuida apenas de disciplinar o exercício do poder político, tendo também a pretensão de limitar as decisões possíveis e impor desde logo outras"22.

O que muda com a constitucionalização do Direito Financeiro é, em primeiro lugar, a atribuição de maior efetividade às obrigações constitucionalmente estabelecidas - daí se

${ }^{19}$ CORTI, Horacio. Derechos fundamentales y presupuesto publico. In CONTI, José Maurício; SCAFF, Fernando Facury (coord.). Orçamentos Públicos e Direito Financeiro. São Paulo: Editora Revista dos Tribunais, 2011, p. 146.

${ }^{20}$ CARVALHO, André Castro. Direito Constitucional Financeiro e Direito Orçamentário Substantivo. In CONTI, José Maurício; SCAFF, Fernando Facury (coord.). Orçamentos Públicos e Direito Financeiro. São Paulo: Editora Revista dos Tribunais, 2011, p. 45.

${ }^{21}$ TORRES, Heleno Taveira. Teoria da Constituição Financeira. Tese apresentada ao Concurso de Títulos e Provas para o cargo de Professor Titular de Direito Financeiro. Faculdade de Direito da Universidade de São Paulo. São Paulo, 2014, p. 102.

${ }_{22}$ MENDONÇA, Eduardo Bastos Furtado de. Constitucionalização das Finanças Públicas no Brasil. Rio de Janeiro: Renovar, 2010, p. 02. 
falar em efetividade financeira ${ }^{23}$, ou, de maneira mais ampla, em concretização de direitos. Em segundo lugar, e intrinsecamente relacionado ao primeiro, é que os direitos fundamentais passam a conferir sentido e objetivo à atividade financeira.

A partir da constitucionalização das finanças públicas, passa-se a pensar que o Direito Financeiro não abarca apenas ritos de elaboração da lei orçamentária (repartição de funções entre Executivo e Legislativo), mas também a destinação de recursos mínimos a determinadas áreas, a vinculação de receitas e a garantia de autonomia financeira a determinados órgãos. Por isso, falar em efetividade financeira significa a viabilização de recursos para a implementação de uma gama de direitos ou para a implementação de um determinado órgão com independência e autonomia. Horacio Corti afirma que a atividade financeira, dentro de uma ordem constitucional, significa obter recursos e realizar gastos visando dar efetividade à Constituição. Deve a Constituição pensar e regular como se financiam os direitos que ela mesma estabelece. É por isso que a existência de direitos e instituições constitucionais condiciona a atividade financeira, cuja finalidade será dar efetividade a esses direitos e instituições ${ }^{24}$.

Seguindo a mesma linha de argumentação, Heleno Taveira Torres afirma que a mudança gerada a partir da constitucionalização do Direito Financeiro (ou o "tratamento do Direito Financeiro pela Teoria da Constituição Financeira material") assume três pressupostos, que merecem ser mencionados: (i) prevalência do princípio do Estado Democrático de Direito, (ii) fins constitucionais como definidores dos objetivos da Constituição $^{25}$, (iii) abertura sistêmica da Constituição Financeira para a realidade mediante os encontros de valores na relação de interconstitucionalidade ${ }^{26}$. Destaca-se aqui

${ }^{23}$ CARVALHO, André Castro. Direito Constitucional Financeiro e Direito Orçamentário Substantivo. In CONTI, José Maurício; SCAFF, Fernando Facury (coord.). Orçamentos Públicos e Direito Financeiro. São Paulo: Editora Revista dos Tribunais, 2011, p. 48.

${ }^{24}$ CORTI, Horacio. Derecho Financiero. Buenos Aires: Alberto Perrot, 1997, p. 259.

25 Segundo o autor, conforme esse segundo pressuposto, "a Constituição Financeira, na sua projeção totalizadora do Estado, não se limita a fins prévios como fins do Estado. Os fins e valores da Constituição foram eleitos pelo poder constituinte ao tempo do exercício da soberania que coloca uma nova Constituição em vigor (...) Não é vedado à política inovar no catálogo de fins, mas caberá sempre às instituições democráticas o atingimento de todos aqueles fins definidos pelo poder constituinte que foram contemplados e afirmados no texto Constitucional" (TORRES, Heleno Taveira. Teoria da Constituição Financeira. Tese apresentada ao Concurso de Títulos e Provas para o cargo de Professor Titular de Direito Financeiro. Faculdade de Direito da Universidade de São Paulo. São Paulo, 2014, pp. 104-105).

${ }^{26} \mathrm{O}$ terceiro pressuposto, de interconstitucionalidade, determina "a convergência, na justaposição imanente das constituições materiais que a integram, para a efetividade da Constituição total. Desse modo, as Constituições Social, Econômica e Tributária interagem com a Constituição Financeira, a compor a atuação do Estado na ordem social e econômica, como forma de concretização dos princípios da força normativa e da unidade da Constituição (TORRES, Heleno Taveira. Teoria da Constituição Financeira. Tese apresentada ao Concurso de Títulos e Provas para o cargo de Professor Titular de Direito Financeiro. Faculdade de Direito da Universidade de São Paulo. São Paulo, 2014, pp. 124-124). 
o primeiro pressuposto, que expressa bem o que se quer marcar com a mudança de paradigma. Com a prevalência do princípio do Estado Democrático de Direito, tem-se uma alteração da relação entre Estado e cidadãos, "com mecanismos de inclusão, maior participação, garantiras formais e materiais, efetividade de direitos e maior equilíbrio entre o exercício de poderes, eficiência administrativa e direito dos particulares". Tal pressuposto indica que "legalidade, direitos fundamentais e democracia são elos inseparáveis no processo de efetividade da Constituição,"27.

Veja-se que a visão apresentada pelos mencionados autores é bastante diferente da perspectiva clássica, essa centrada na relação entre Executivo e Legislativo.

Todas essas considerações apontam que a mudança de paradigma, a partir (principalmente) da constitucionalização das finanças públicas, atribuiu maior efetividade aos fins e valores constitucionais. Porém, não basta pensar apenas em maior efetividade, há que se considerar que a constitucionalização do Direito Financeiro deu também unidade de sentido a seus institutos, sentido este que passa a se concentrar na observância de finalidades constitucionais, dentre as quais a do sistema de direitos fundamentais.

A necessária observância das finalidades constitucionais pelo Direito Financeiro traz à tona o segundo aspecto acima citado, qual seja, os direitos fundamentais passam a ser um fim e um sentido para os institutos financeiros (tanto tributários como orçamentários).

A partir desse raciocínio, encontra-se um dos caminhos de concretização do Direito Financeiro, ou melhor, do Direito Constitucional Financeiro: uma das funções do orçamento é dar efetividade aos direitos fundamentais - "a atividade financeira é por si só um elemento do sistema dos direitos fundamentais e, de outro lado, é também esse sistema que dá sentido à atividade financeira"28.

Essa nova concepção não é limitada ao Direito Financeiro, mas insere-se em uma nova visão acerca dos direitos fundamentais na ordem constitucional.

Canotilho fala em vinculação do legislador (aqui em um sentido amplo envolvendo qualquer produtor de atos normativos) aos direitos fundamentais, cuja dimensão positiva se refere ao dever de estes conformarem as relações entre Estado e cidadãos segundo as medidas diretivas e materiais consubstanciadas nas normas garantidoras de direitos e

\footnotetext{
${ }^{27}$ TORRES, Heleno Taveira. Teoria da Constituição Financeira. Tese apresentada ao Concurso de Títulos e Provas para o cargo de Professor Titular de Direito Financeiro. Faculdade de Direito da Universidade de São Paulo. São Paulo, 2014, pp. 102-105.

${ }^{28}$ CORTI, Horacio. Derechos fundamentales y presupuesto publico. In CONTI, José Maurício; SCAFF, Fernando Facury (coord.). Orçamentos Públicos e Direito Financeiro. São Paulo: Editora Revista dos Tribunais, 2011, pp. 149-150.
} 
liberdades. O mesmo autor fala também em vinculação da administração aos direitos fundamentais, inclusive relativamente aos atos de governo: "a força dirigente dos direitos fundamentais relativamente ao poder executivo impõe-se mesmo perante actos de governo, praticados no exercício de uma função política ou governamental"29.

Ingo Sarlet aponta que os direitos fundamentais passam de sua função originária de instrumentos de defesa de liberdade individual a integrar um "sistema axiológico que atua como fundamento material de todo o ordenamento jurídico" ${ }^{\text {30 }}$. Ou, ainda, os direitos fundamentais passam a se apresentar como um conjunto de valores objetivos básicos e fins diretivos da ação positiva dos poderes públicos ${ }^{31}$. É por isso que se fala em dimensão objetivo-valorativa dos direitos fundamentais ou eficácia dirigente, qual seja, aquela relativa à "ordem dirigida ao Estado no sentido de que a este incumbe a obrigação

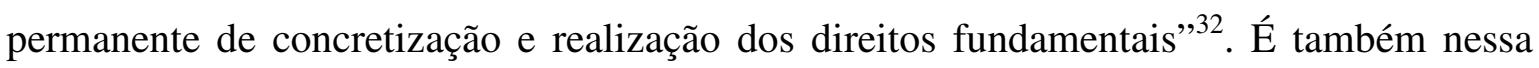
linha que se extrai do artigo $5^{\circ}, \S 1^{\circ}$ da Constituição Federal a tarefa dos órgãos estatais de reconhecer a maior eficácia possível dos direitos fundamentais ${ }^{33}$.

Aqui se encontra um dos grandes desafios do Estado e do Direito Financeiro, dar efetividade aos direitos sociais prestacionais, a exemplo da saúde, educação, assistência social. Diferentemente dos direitos de defesa (que preservam e protegem determinada situação), os direitos prestacionais exigem uma conduta positiva do Estado, estando “intimamente vinculados às tarefas de melhoria, distribuição e redistribuição de recursos existentes, bem como à criação de bens essenciais não disponíveis para todos os que deles

${ }^{29}$ CANOtilho, J. J. Gomes. Direito Constitucional e Teoria da Constituição. $7^{\mathrm{a}}$ ed. Coimbra: Almedina, 2003, p. 441 e p 445. Novamente, ressalva-se que tal vinculação não é absoluta ou livre de problemas. O próprio Canotilho alerta que "a realização dos direitos fundamentais é, neste sentido, um importante problema de competência constitucional: ao legislador compete, dentro das reservas orçamentais, dos planos econômicos e financeiros, das condições sociais e econômicas do país, garantir as prestações integradoras dos direitos sociais, econômicos e culturais. Essas ressalvas não significam cair no "esquema relacional leidireitos" do século passado, vez que "o legislador inativo suporta uma censura jurídico constitucional de violação de direitos fundamentais equivalente à antiga interferência ilícita no âmbito da liberdade e propriedade dos cidadãos" (CANOTILHO, J. J. Gomes. Constituição Dirigente e vinculação do legislador. $2^{\text {a }}$ ed. Coimbra: Coimbra Editora, 2001, p. 369).

${ }^{30}$ SARLET, Ingo Wolfgang. A Eficácia dos Direitos Fundamentais. Porto Alegre: Livraria do Advogado, 2001, p. 63.

${ }^{31}$ Ibidem, p. 143.

32 Ibidem, p. 147.

${ }^{33}$ Tal interpretação não significa que é possível a todos os órgão, a exemplo do Judiciário, viabilizar a fruição dos direitos fundamentais mediante o preenchimento de lacunas. Como ressalta Ingo Sarlet, "especialmente no que concerne aos direitos fundamentais de natureza prestacional, verifica-se que os limites de reserva do possível, da falta de qualificação (e/ou legitimação) dos tribunais para implementação de determinados programas socioeconômicos, bem como a colisão com outros direitos fundamentais podem, dentre outros aspectos, exercer uma influência decisiva (SARLET, Ingo Wolfgang. A Eficácia dos Direitos Fundamentais. Porto Alegre: Livraria do Advogado, 2001, p. 249). 
necessitem"34. Se é intrínseca a relação entre distribuição de recursos e direitos prestacionais, não se pode pensá-la sem considerar o orçamento. O Direito Financeiro é ponto fulcral nesse debate, que será retomado ao longo do presente trabalho.

Em síntese, há um paradigma clássico no Direito Financeiro centrado no controle do Legislativo sobre os recursos e na organização das finanças pelo Executivo (ideia que não pode ser por completo abandonada); e há um novo paradigma, que considera o orçamento como forma de dar efetividade à Constituição, mormente como instrumento de implementação do Estado Democrático de Direito e dos direitos fundamentais. Na visão adotada por este trabalho, a concretização do Direito Constitucional Financeiro envolve não apenas procedimentos formais de elaboração e controle orçamentário, mas impõe que sejam considerados os diversos aspectos com que se iniciou esse capítulo, dentre os quais: alcançar maior efetividade dos direitos fundamentais, garantir maior legitimidade democrática, permitir o máximo de transparência, controle e planejamento do gasto público.

Essa a premissa que lidará o presente trabalho na interpretação de um mecanismo específico: o contingenciamento. Essa premissa será importante para investigar se o contingenciamento tem sido aplicado dentro de seus limites jurídicos e em que medida sua aplicação tem impedido a concretização do Direito Financeiro. E será também importante para propor formas de controle perante a prática do contingenciamento.

Fixados os objetivos do Direito Financeiro, dentro de um novo paradigma, é momento de adentrar nos obstáculos à sua concretização, os quais se pretende apresentar sob duas perspectivas.

Primeiro, por ter uma forte interface com os âmbitos político e econômico, o Direito Financeiro, em especial o orçamento, é objeto de intenso conflito de interesses, de paixões e de dominação. Tais conflitos, decorrentes da própria natureza humana, impedem uma concretização adequada do Direito Financeiro. Esse o tema do item 1.3.

Em segundo lugar, também como possível obstáculo, está a aplicação dos instrumentos de flexibilização orçamentária. Embora sejam mecanismos fundamentais para situações de exceção, seu uso desmedido e, por vezes, fora de seus limites jurídicos, também tem impedido a concretização do Direito Financeiro. Esse o tema a ser tratado no

\footnotetext{
${ }^{34}$ Os direitos sociais prestacionais exigem maior grau de conduta positiva do Estado. Estão usualmente no centro do debate acerca do financiamento de direitos. Isto não quer dizer que os demais tipos direitos (direitos de defesa) não custam ou não exigem atuação do Estado. Para a distinção de direitos de defesa e direitos prestacionais, vide SARLET, Ingo Wolfgang. A Eficácia dos Direitos Fundamentais. Porto Alegre: Livraria do Advogado, 2001, p. 252 e seguintes.
} 
item 1.4. Por ser o contingenciamento um instrumento de flexibilização orçamentária, tais considerações serão importantes para contextualizá-lo e, posteriormente, é por ele que seguirá o presente estudo.

\subsection{Os conflitos de interesses, paixões e dominação e a concretização do Direito Financeiro}

Antes de prosseguir na análise jurídica dos obstáculos à concretização do Direito Financeiro, em especial com o estudo do contingenciamento, propõem-se algumas linhas sobre os conflitos de interesses e de poder existentes na aplicação do direito e aqui voltadas ao gasto público.

A decisão sobre o gasto público é fonte de intensa disputa de poder e ponto central no conflito de interesses: desde os embates entre os Poderes (Legislativo, Executivo e Judiciário), até disputas por diferentes grupos econômicos e políticos presentes na sociedade. Esses conflitos revelam igualmente relações de dominação: através da alocação de recursos perpetuam-se ou revertem-se relações de poder. Como bem coloca Regis Fernandes de Oliveira "o gasto público é, pois, elaborado por quem manda e destinado a quem o mandante desejar, o que inclui todos os seus vícios e eventuais virtudes" ${ }^{\text {}}$.

Embora a análise desses conflitos no âmbito orçamentário não seja decisiva para as conclusões jurídicas acerca do contingenciamento, ela é de extrema relevância para uma melhor compreensão da aplicação do Direito Financeiro, em especial quando sua concretização é por eles influenciada. Ademais, como já se pode observar, o Direito Financeiro está em intrínseco embate com os demais sistemas sociais, como a Política e a Economia, e tem relação muito próxima com os conflitos de poder e de interesses, sejam políticos ou econômicos.

Destaca-se, ainda, que esses conflitos de interesses políticos e econômicos, bem como as mencionadas relações de dominação, são verificados no Direito Financeiro como um todo, mas é através da observação dos instrumentos de flexibilização orçamentária que aparecem de modo mais desvelado, especialmente porque se trata de normas que excepcionam a regra. É o momento em que se torna mais visível a manipulação de recursos para um determinado fim. É o ponto de conflito mais claro entre os campos do Direito, da

\footnotetext{
${ }^{35}$ OLIVEIRA, Regis Fernandes de. Gastos públicos. São Paulo: Editora Revista dos Tribunais, 2012, p. 07.
} 
Política e da Economia, entre os interesses públicos e privados, entre as diferentes visões de poder.

Assim, se, por um lado, os instrumentos de flexibilização orçamentária permitem ao gestor público adaptar a condução do gasto público a variáveis políticas e econômicas surgidas no curto prazo, o que é de fundamental interesse público; de outro lado, a partir de distorções na sua aplicação, tais instrumentos têm se mostrado como mecanismos de condução de interesses que não aqueles delimitados pelas normas jurídicas de Direito Financeiro, impedindo assim sua concretização.

Justifica-se, portanto, essa breve digressão para fora do pensamento jurídico. É o que também fez Regis Fernandes de Oliveira, em sua obra "Gastos Públicos", introduzida a partir de alguns importantes questionamentos:

Quem decide onde gastar? Quem decide o destino dos recursos? Quais as
motivações que levam o ator político a enviar recursos para atender a ou
b? Quais as influências que o agente político recebeu para decidir de tal
forma? Quais seus interesses mais remotos no atendimento de
determinado assunto? Quem está por detrás dele, a municiá-lo de
informações ou pressioná-lo para que se decida de tal maneira? Quais os
sentimentos (ódio, medo ou esperança) que fez com que agisse assim?
Quais as forças subversivas que estão em ação? Tais questões ficam sem
resposta na análise estritamente formal das despesas públicas (....).

São alguns desses questionamentos que inspiram a reflexão do presente item, no qual serão mencionados alguns textos não jurídicos, com o objetivo de caracterizar o orçamento como resultado de paixões, de interesses e de poder e como instrumento de dominação. E além disso, verificar em que medida pode ser o Direito Financeiro um vetor contrário, ou ao menos amenizador, à dominação e aos interesses meramente privados, rumo à mudança social e à concretização das premissas e objetivos de que se tem tratado nesse capítulo.

Cumpre esclarecer que os autores adiante mencionados não tratam diretamente do orçamento. Tratam, porém, de decisões, cujas ideias são aplicáveis às decisões orçamentárias, a exemplo de Freud, Hume e Schopenhauer, autores que possibilitam olhar uma decisão jurídica como resultado desse embate entre paixões e interesses.

Para esse olhar, bastam duas observações iniciais. Primeiro, não há dúvidas que o orçamento é resultado de um conjunto de decisões dos mais variados atores - chefe do executivo, parlamentares, membros de partidos políticos, componentes de conselhos deliberativos e consultivos, técnicos e servidores públicos atuantes nos três Poderes,

${ }^{36}$ Ibidem, p. 15. 
cidadãos participantes de reuniões do orçamento participativo, dentre outros. Em segundo lugar, consequência da primeira, não deve causar estranheza a afirmação de que as escolhas englobadas no orçamento decorrem, direta ou indiretamente, dos valores, objetivos, interesses e paixões de tais atores. Ressalta-se que isso não necessariamente se mostra como algo contrário ao interesse público, mas é apenas algo que decorre da própria natureza humana.

Esse o raciocínio que se obtém a partir de alguma das concepções de Freud sobre o propósito da vida. Para ele, o propósito da vida é a busca incessante pelo prazer: são as “pulsões" que movem o homem ${ }^{37}$. Questiona Freud, em seu livro "O mal-estar na cultura": "o que os próprios seres humanos, através de seu comportamento, revelam ser a finalidade e o propósito de suas vidas?”. E logo responde: “eles aspiram à felicidade, querem se tornar felizes e assim permanecer" ${ }^{\prime 38}$.

Ocorre que essa busca pela felicidade será limitada ("nossas possibilidades de felicidade já são limitadas pela nossa constituição") e por isso o homem experimentará também a infelicidade, decorrente da ameaça do próprio corpo, do mundo externo ("forças superiores") e das relações com os outros seres humanos ${ }^{39}$. Essa última fonte de sofrimento, denominada de social, "constituída pelo próprio homem e que deveria representar sua proteção e benefício", é a que Freud centra sua atenção. Segundo o autor, a partir de um determinado momento da história da humanidade, houve para ele um "passo cultural decisivo": a "substituição do poder do indivíduo pelo poder da comunidade" Nesse momento, o poder da comunidade buscou restringir cada um de seus membros, justamente para possibilitar a busca por satisfações de modo geral. Ou seja, enquanto indivíduo, o homem não conhecia restrições aos seus impulsos. Foi somente a partir dessas restrições que passou a ser possível a vida em sociedade, inclusive como forma de evitar sofrimentos.

No entanto, privar os impulsos e sua satisfação é tarefa árdua aos homens ${ }^{41}$ e por isso que "boa parte da luta da humanidade se concentra em torno da tarefa de encontrar um

${ }^{37}$ FREUD, Sigmund. O mal-estar na cultura. Tradução de Renato Zwick; revisão técnica e prefácio de Márcio Seligmann-Silva; Ensaio Bibliográfico de Paulo Endo e Edson Sousa. Porto Alegre: L\&PM, 2010.

${ }^{38}$ Ibidem, p. 62.

${ }^{39}$ Ibidem, p. 63

${ }^{40}$ Ibidem, p. 97.

41 "Não é tarefa fácil entender como ser torna possível privar um impulso de sua satisfação. Não é exatamente algo isento de perigo; caso não seja compensado economicamente, deve-se estar preparado para sérias perturbações" (FREUD, Sigmund. O mal-estar na cultura. Tradução de Renato Zwick; revisão técnica e prefácio de Márcio Seligmann-Silva; Ensaio Bibliográfico de Paulo Endo e Edson Sousa. Porto Alegre: L\&PM, 2010, p. 102). E mais a frente: "a cultura precisa fazer de tudo para impor limites aos impulsos agressivos do homem, para deter sua manifestações através de formações psíquicas reativas. Daí, portanto, o 
equilíbrio conveniente, ou seja, capaz de proporcionar felicidade, entre essas exigências individuais e as reivindicações culturais das massas" ${ }^{\text {42 }}$. Há um conflito, portanto, entre manutenção das exigências individuais e possibilidade de atendimento do coletivo.

O conflito existe e é tema central para qualquer Estado de Direito. É recorrente o questionamento sobre qual seria o papel do Estado e do Direito dentro desse equilíbrio entre reivindicações da coletividade e manutenção da liberdade individual: deve-se tributar mais, com aumento dos gastos públicos, a fim de melhor atendimento às "reivindicações das massas"? Ou deve-se privilegiar a liberdade individual, permitindo aos homens maior espaço para a satisfação de seus impulsos? Essa perspectiva certamente está por trás de escolhas orçamentárias, no qual se encontrará o desejo de satisfação dos impulsos de um e o desejo de restrição dos impulsos de outros. Daí se pode dizer que, inevitavelmente, as decisões orçamentárias serão também, resultado do conflito dessas pulsões e paixões.

Avançando no raciocínio, mencionam-se as contribuições de David Hume, que tratou da norma (e as decisões orçamentárias resultam em normas) como resultado de paixões, e não da razão. Explica o autor: "a razão sozinha não é motivo para uma ação (...), é incapaz de impedir uma volição ou de disparar nossa preferência com qualquer paixão ou emoção"43. Nessa linha, são as paixões que dominam o homem; são elas, em última instância, que fundamentam suas ações.

Mais uma vez questiona-se qual seria o papel do Direito frente ao argumento de que as normas são resultado da paixão e não da razão: seria possível atingir de alguma forma o interesse público? Em que medida as normas importam?

David Hume possui uma visão bastante pessimista nesse ponto. Para o autor, há uma convenção artificial por meio da qual se define a justiça e o interesse público, não havendo "na mente dos homens uma paixão como o amor à humanidade, concebida meramente enquanto tal, independentemente de qualidades pessoais, de favores ou de uma relação da outra pessoa com vocể,44. Embora o autor assuma a existência de sentimentos afetuosos e de preocupação entre os seres humanos, isso não significa "que haja uma afeição universal pela humanidade, uma vez que essa preocupação se estende para além de

emprego de métodos que têm o propósito de estimular os homens a identificações e relacionamentos amorosos de meta inibida, daí as limitações da vida sexual e daí também o mandamento ideal que ordena amar o próximo como a si mesmo, e que realmente se justifica pelo fato de nenhuma outra coisa se opor tanto à natureza original do homem" (Ibidem, p. 125).

${ }^{42}$ Ibidem, p. 99.

${ }^{43}$ HUME, David. Tratado da natureza humana - uma tentativa de introduzir o método experimental de raciocínio nos assuntos morais. São Paulo: Editora UNESP, 2005, p. 449.

${ }^{44}$ Ibidem, 521. 
sua própria espécie” ${ }^{\Perp 4}$. Ou seja, interesse público e justiça não são decorrentes da razão, tampouco representam uma natureza humana benevolente e de amor à humanidade. Pelo contrário, segundo Hume, a justiça se origina "do egoísmo e da generosidade restrita dos homens, em conjunto com a escassez das provisões que a natureza ofereceu para suas necessidades". Tampouco, ao menos originalmente, o motivo para que os homens observem essa justiça artificial é o "respeito pelo interesse público ou uma benevolência forte e irrestrita", inclusive porque, se assim fosse, e os homens fossem dotados de tal benevolência, as regras de justiça jamais precisariam ter sido imaginadas ${ }^{46}$.

Certamente se trata de uma visão bastante extremada e das mais pessimistas, mas para elas chama-se a atenção para discutir o papel do Direito Financeiro nesse embate de paixões e como fruto das mesmas. Se adotada uma visão pessimista acerca das normas, poder-se-ia parar por aqui, mas entende-se que o Direito apresenta caminhos e perspectivas positivas. Se assim não fosse, o próprio Hume desprezaria as "regras de justiça". Novamente, o que se quer é destacar os problemas advindos das próprias decisões humanas, que resultam em normas, em orçamento.

Não é muito diferente o entendimento de Schopenhauer, para quem o interesse público também não se configura como o motivo original das ações humanas. Os atos podem muito bem ser justificados pelo interesse público, mas a posteriori, porque a decisão já está tomada de antemão pela vontade. O intelecto apenas justifica o que a vontade já decidiu.

Nas palavras de Schopenhauer, “o intelecto aqui pode apenas uma coisa: esclarecer a natureza dos motivos (...); quanto a determinar a vontade em si mesma, é isto o que se passa: a vontade é impenetrável por ele, e ainda mais inacessível" ${ }^{\text {"47 }}$. E o que a vontade (que se reflete nas ações humanas) busca, segundo Schopenhauer, não leva a uma conclusão distinta daquela dada por Freud e Hume: "a vontade, em todos os seus aspectos, está submetida à necessidade"48, “a injustiça é o caráter próprio da ação de um indivíduo que entende a afirmação da vontade enquanto manifestada pelo seu próprio corpo, até negar a vontade manifestada pela pessoa do outro"49. Em função dessa concepção de vontade, Schopenhauer conclui que os Estados só podem ser mais ou menos imperfeitos, já

\footnotetext{
${ }^{45}$ Ibidem, p. 521.

${ }^{46}$ Ibidem, p. 536.

${ }^{47}$ SCHOPENHAUER, Arthur. O mundo como vontade e representação. Trad. M. F. Sá Correia. Rio de Janeiro: Contraponto, 2001, p. 306.

${ }^{48}$ Ibidem, p. 321.

${ }^{49}$ Ibidem, p. 355.
} 
que "para fundar um Estado perfeito, seria preciso começar por fazer seres a que a sua natureza permitisse sacrificar totalmente o seu bem particular ao bem público"50.

Novamente se percebe a dificuldade em se sobrepor interesses públicos sobre privados, mesmo sob a aplicação do direito: na concepção dos citados autores, não seria "natural" ao homem a busca do interesse público, esse não é o motivo original de seus atos, tampouco é ele que move originalmente as ações humanas.

A partir dessas considerações, pode-se fundamentar uma das observações expostas, no sentido de que o orçamento, como resultado das ações humanas, estará no centro dos conflitos, resultará de um embate entre os diferentes impulsos dos homens, resultará das reivindicações dos diversos valores dos sujeitos que decidem. Para citar ainda um último autor, o Direito é a maneira regulamentada de fazer a "guerra",51, e o Direito Financeiro cuidará de um aspecto específico dessa "guerra" entre os homens: a disputa por recursos públicos.

Firmadas essas premissas, o raciocínio deve caminhar para a análise desses conflitos no âmbito do Estado, já que é dentro dele que as decisões dos homens são tomadas, dentre as quais a produção das normas e do orçamento. Sobre esse ponto, não há dúvidas que os aspectos decorrentes da natureza humana, apontadas por Freud, Hume e Schopenhauer, são levados para dentro do Estado. A despeito da previsão de busca pelo interesse público, da existência de procedimentos razoavelmente eficazes, da validade de um sistema jurídico, as paixões e os interesses continuam em conflito dentro do Estado. Podem ser sim amenizados, mas não se extinguem em nome de um princípio abstrato da supremacia do interesse público. É isso que se extrai dos autores que analisaram a formação do Estado, a exemplo de Hobbes.

Hobbes aponta para a necessidade de um "contrato social”, justamente perante o conflito entre os homens ("o homem é o lobo do homem" 52 ). Como explica o filósofo contratualista: "se dois homens desejam a mesma coisa, ao mesmo tempo em que é impossível ela ser gozada por ambos, eles tornam-se inimigos" ${ }^{2}$. Decorrente de sua própria natureza de competir, discordar e buscar a glória, os homens representam ameaça uns aos outros, relativamente ao lucro, à segurança e à reputação. Sem um poder comum, a própria natureza do homem leva a uma condição de guerra, "e uma guerra que é de todos

\footnotetext{
${ }^{50}$ Ibidem, p. 360.

${ }^{51}$ FOUCAULT, Michel. A verdade e as formas jurídicas. Rio de Janeiro: PUC, 2008, p. 56.

${ }^{52}$ Frase presente na obra "Sobre o cidadão".

${ }^{53}$ HOBBES, Thomas. Leviatã. Coleção Os Pensadores. São Paulo: Editora Nova Cultura, 2010, p. 109.
} 
os homens contra todos os homens" ${ }^{\text {54 }}$. Nesse sentido, o Estado é justamente instituído para evitar a guerra de todos contra todos, conter a natureza humana e permitir a convivência. É necessário, portanto, um Estado, o Leviatã ou o "homem artificial".

Nesse raciocínio, interessante notar que Hobbes qualifica o Estado de "homem artificial". Essa denominação vai ao encontro da afirmaçãode que os vícios do homem são também os vícios do Estado: "para descrever a natureza deste homem artificial, examinarei, primeiro, sua matéria, e seu artífice; ambos os quais são o homem" ${ }^{, 55}$. Dessa concepção decorre o argumento de que prevalece que o detentor do poder promova o seu interesse pessoal: "seja quem for que seja portador da pessoa do povo (...) é também portador de sua própria pessoa natural (...), embora tenha cuidado de promover o interesse comum, terá mais ainda (...) o de promover seu próprio bem pessoal, assim como o de sua família, parentes e amigos",56.

Hobbes concluirá o argumento, explicando por que o portador do poder preferirá o interesse pessoal, quando este estiver em conflito com o interesse público. Em sentido bastante próximo aos autores já mencionados, diz: "em geral as paixões humanas são mais fortes que a razão" ${ }^{\text {57 }}$. Muitas vezes até se pode alcançar também o interesse público mas, seguindo nessa linha de argumentação, haverá também contemplação de interesses privados. Pensando em um exemplo no âmbito do gasto público, esse argumento parece bastante factível. Pode-se pensar que a alocação de recursos para uma obra de determinada região representa o atendimento do interesse público. Porém, pode-se identificar interesses do detentor do poder - em contratar uma empresa específica e privilegiar a região que o apoiou nas eleições, por exemplo.

Prosseguindo, a concepção de Estado encontrada em Hobbes, em que sobressaem os interesses privados em detrimento do interesse público (ou muitas vezes interesses privados disfarçados de interesse público), não diverge da descrição marxista de Estado, extraída da Crítica da filosofia do direito de Hegel ${ }^{58}$. Uma das críticas feitas por Marx a Hegel é com relação à separação que este propõe entre Estado e sociedade civil, entre os interesses particulares e o universal. Para Marx, tal abstração não é factível; a relação Estado e Sociedade civil não é algo hierarquizado, justamente porque "o homem não é um

\footnotetext{
${ }^{54}$ Tal condição de guerra não representa necessariamente uma luta real, mas é também a "disposição para tal durante todo o tempo em que não há garantia do contrário". (HOBBES, Thomas. Leviatã. Coleção Os Pensadores. São Paulo: Editora Nova Cultura, 2010, p. 109).

${ }^{55}$ HOBBES, Thomas. Leviatã. Coleção Os Pensadores. São Paulo: Editora Nova Cultura, 2010, p. 27.

${ }^{56}$ Ibidem, p. 154.

${ }^{57}$ Ibidem, p. 154.

${ }^{58}$ MARX, Karl. Crítica da filosofia do direito de Hegel. Trad. de Rubens Enderle e Leonardo de Deus. São Paulo: Boitempo, 2005.
} 
ser abstrato, acocoado fora do mundo. O homem é o mundo do homem, o Estado, a sociedade, ${ }^{, 59}$.

Há aqui uma relação direta da concepção de Marx com o "homem artificial" de Hobbes, tanto assim que, quanto ao conceito abstrato de Estado e de homem, Marx questiona Hegel: "mas quem pode jamais duvidar que o Estado age por intermédio de indivíduos? (...) O monarca é, no Estado, o momento da vontade individual, da autodeterminação sem fundamento, do arbítrio" ${ }^{\text {60 }}$.

Seguindo na crítica, nem mesmo a burocracia do Estado capitalista moderno representa os interesses universais, separados dos interesses privados, como defendia Hegel. A burocracia não é uma abstração, não possui um espírito próprio, separado da sociedade civil, e que agirá no alcance ao interesse público, ao interesse de Estado. Marx toma como pressuposto uma realidade concreta/material (materialismo histórico) para concluir pela interrelação e mesmo pela confusão entre Estado, burocracia e sociedade civil, especialmente em razão de não se encontrar um espírito abstrato, de interesses separados:

As corporações são o materialismo da burocracia e a burocracia é o espiritualismo das corporações. A corporação é a burocracia da sociedade civil; a burocracia é a corporação do Estado. Por isso, na realidade, ela se defronta, na condição de sociedade civil do Estado, com o Estado da sociedade civil, com as corporações (...) O espiritualismo desaparece com o materialismo a ele contraposto. $O$ mesmo espírito que criam na sociedade, a corporação cria, no Estado, a burocracia. Portanto, logo que o espírito corporativo é atacado, é atacado o espírito da burocracia; e, se antes, a burocracia combateu a existência das corporações para criar espaço para sua própria existência, agora ela busca manter à força a existência das corporações para salvar o espírito corporativo, seu próprio espírito. ${ }^{61}$

Se a formação do Estado não foi capaz de impedir que interesses privados continuassem a prevalecer sobre interesses públicos, não é forçoso imaginar o orçamento como ponto central nessa disputa. Sendo um dos principais instrumentos de ação e disputa política, é razoável concluir que servirá como instrumento de dominação. O orçamento contemplará, assim, os interesses desses indivíduos e se voltam para que os mesmos se mantenham no poder. O gasto público é o instrumento de obtenção de apoio político, de

\footnotetext{
${ }^{59}$ Ibidem, p. 145.

${ }^{60}$ Ibidem, 46.

${ }^{61}$ Ibidem, pp. 64-65.
} 
contenção de insatisfações populares, de ataque ao opositor. Será o orçamento, nessa linha de $\operatorname{argumentação,~instrumento~de~dominação~}{ }^{62}$.

Menciona-se, aqui, um dos principais autores a estudar o tema da dominação: Max Weber. O autor definia dominação como "a probabilidade de encontrar obediência para ordens específicas dentro de determinado grupo de pessoas"; na dominação há submissão, há um mínimo de vontade de obedecer, um interesse na obediência ${ }^{63}$. Dentre os tipos de dominação descritos por Weber, predominou na sociedade capitalista a dominação de caráter racional, através de uma administração burocrática impessoal, hierarquizada, calculável, com competências fixas, que age a partir de regras técnicas e de forma racional, o que foi fundamental para seu próprio desenvolvimento. Essas ao menos são as pretensões da dominação legal, segundo Weber.

Ocorre que, mesmo por essa administração burocrática, típica da sociedade moderna, o Estado continua agindo por meio de indivíduos. É impossível essa separação entre Estado e indivíduos de forma integral, como já assinalado. Nesse sentido, esclarece Marilena Chauí: “O Estado aparece como a realização do interesse geral, mas, na realidade, ele é a forma pela qual os interesses da parte mais forte e poderosa da sociedade ganham a aparência de interesses da sociedade" ${ }^{64}$.

Esse Estado não pode realizar sua função reguladora da sociedade se aparecesse como realização dos interesses particulares e é por isso que suas funções serão instrumentalizadas através das leis e do Direito (dominação impessoal). Trata-se justamente da dominação racional (dominação legal) apontada por Weber, a partir da qual o Estado aparece como um poder que não pertence a ninguém e aparece como um poder desligado dos homens. Ao menos há uma pretensão para tal, o que não quer dizer que inexiste a dominação de um ou mais grupo(s) por outro(s). Conforme Regis Fernandes de Oliveira, "o que prepondera é a vontade individual do chefe ou a vontade coletiva de um grupo (...), quem irá decidir sobre o orçamento, então, e sobre o destino dos recursos será este grupo que, em princípio, não estão preocupadas com os outros (...) Estão pensando em si próprias ou no seu grupo" 65 .

O que ocorre é que a origem e a finalidade do poder do Estado dirigido por homens e que dirige os homens permanecem, por vezes, secretas: “como o Estado ganhou

\footnotetext{
${ }^{62}$ Sobre as diversas formas de atuação do orçamento como instrumento de dominação, vide OLIVEIRA, Regis Fernandes de. Gastos públicos. São Paulo: Editora Revista dos Tribunais, 2012, pp. 124-143.

${ }^{63}$ WEBER, Max. Economia e Sociedade. Volume 01. Brasília: Editora UnB, 1991, p. 139.

${ }^{64}$ CHAUÍ, Marilena. O que é ideologia. São Paulo: Brasiliense, 2004, p. 27.

${ }^{65}$ OLIVEIRA, Regis Fernandes de. Gastos públicos. São Paulo: Editora Revista dos Tribunais, 2012, p. 130.
} 
autonomia, ele parece ter sua própria história, suas fases e estágios próprios, sem nenhuma dependência da história social efetiva. Está aberto o caminho para a ideologia política (...) ${ }^{\text {66 }}$. Explica Marilena Chauí que é a ideologia o elemento que permite esconder a origem e a finalidade do Estado. É o conjunto de ideias, valores, normas ou regras que indica e prescreve o modo como a sociedade deve pensar, sentir, valorizar. Faz-se crer que um determinado modo de convivência é melhor do que outros. É o conjunto lógico e sistemático de valores e normas por meio do qual se permite o exercício de uma determinada dominação ${ }^{67}$. Trata-se de uma dominação simbólica, sem violência física, através da persuasão de valores.

Certamente que essa ideologia está em todo o sistema jurídico, está envolta nas decisões orçamentárias. Pode-se dizer, inclusive, que o orçamento é parte do aparelho ideológico do Estado, utilizando a denominação de Althusser ${ }^{68}$. É, por exemplo, por meio da distribuição de recursos pelo Executivo para o Legislativo (ou para os entes subnacionais) que o Estado, e os dirigentes que nele se encontram, mantém a dominação.

É também através de uma determinada forma de "orçamentação", que se impedem mudanças nas relações de poder e se reforçam as práticas clientelistas. É o que ocorre, como defende Nazaré da Costa Cabral, com o incrementalismo orçamentário, prática na qual o "orçamento de cada ano corresponde globalmente a uma mera revisão do orçamento anterior, contendo apenas alterações marginais" ${ }^{\text {, }}$. Essa forma de orçamentação tem

${ }^{66}$ CHAUÍ, Marilena. O que é ideologia. São Paulo: Brasiliense, 2004, p. 28

${ }^{67}$ Partindo de uma concepção marxista, Marilena Chauí define a função da ideologia na sociedade capitalista: "dar aos membros da sociedade dividida em classes uma explicação racional para as diferenças sociais, políticas e culturais, sem jamais atribuir tais diferenças à divisão da sociedade em classes, a partir das divisões na esfera de produção (...) a função da ideologia é apagar as diferenças, como de classes, e de fornecer aos membros da sociedade o sentimento da identidade social, encontrando certos referenciais identificadores de todos e para todos, como, por exemplo, a Humanidade, a Liberdade, a igualdade, a Nação ou o Estado" (CHAUÍ, Marilena. O que é ideologia. São Paulo: Brasiliense, 2004, pp. 43-44).

${ }^{68}$ ALTHUSSER, Louis. Ideologia e aparelhos ideológicos do Estado. $3^{\mathrm{a}}$ ed. Lisboa: Presenca, 1980.

Althusser aponta para dois aparelhos por meio dos quais o Estado exerce a dominação: o aparelho repressivo do Estado e o aparelho ideológico do Estado. Descrevendo o conceito marxista, Althusser aponta que o Estado (mais especificamente o aparelho repressivo de Estado) "é uma máquina de repressão que permite às classes dominantes assegurar a sua dominação sobre a classe operária”. A esse conceito, Althusser acrescenta (segundo o autor, apenas explicita algo que já se encontrava na teoria marxista) o conceito de aparelhos ideológicos de Estado: "um certo número de realidades que se apresentam ao observador sob a forma de instituições distintas e especializadas", a exemplo das escolas, das igrejas, da família, dos sindicatos, do sistema jurídico (este é ao mesmo tempo aparelho repressivo e aparelho ideológico) (p. 43). Esses dois aparelhos que compõem o Estado se distinguem pelo modo como funcionam (ao menos majoritariamente), o repressivo pela violência, o ideológico pela ideologia (p. 46). Segundo o autor, uma determinada classe dominante apenas consegue se manter no poder e impor suas condições e interesses se exerce a hegemonia sobre os aparelhos ideológicos.

${ }^{69}$ Segundo a autora, o incrementalismo orçamental é caracterizado, em suma, pelos seguintes elementos: a) orçamentação ligada à base, que consiste na expectativa geral de que a despesa irá manter-se; b) orçamentação é consensual, ou seja, formado por acordos mínimos sobre as políticas públicas; c) a orçamentação é histórica, pois há uma herança do passado; d) a orçamentação é fragmentada, não incide 
produzido dois efeitos essenciais, intrinsecamente relacionados ao tema da dominação aqui tratado.

O primeiro efeito é o de enfatizar que o processo de elaboração orçamentária é uma tarefa administrativa que envolve "um conjunto de atores que constituem a máquina burocrática do Estado (burocratas), ou que com eles se relacionam de forma directa (governantes e políticos em geral) ou indirecta (lobbies e grupos de interesses)". Desse efeito denota-se que os conflitos de interesses vão se acomodando no orçamento, de forma a salvaguardar o poder. Decorre também a ideia de que "o orçamento é um instrumento de preservação desse poder e que a forma mais sensata de o assegurar consiste em ir satisfazendo em pequenas doses, um pouco, os interesses de todos”. A conclusão da autora sobre o efeito causado pelo orçamento incremental não poderia ser outra: ao atender essa "clientela", "o orçamento parece assumir-se como um instrumento de perpetuação do status quo; é conservador, é tradicionalista; não é revolucionário" ${ }^{\text {,70. }}$.

O segundo efeito, relacionado ao primeiro, é o de que se nega a funcionalidade das Finanças Públicas, rejeita-se a discricionariedade orçamental e a pretensão de ativismo financeiro: "só uma pequena parte do Orçamento se traduz em verdadeiras alterações, ou seja, em decisões de mutação política"71. Ou seja, o orçamento não consegue se valer como vetor de mudanças.

Feitas todas essas considerações sobre a atuação dos indivíduos sobre as decisões orçamentárias e sobre essa atuação no âmbito do Estado, reformulam-se os questionamentos que se têm feito: frente aos conflitos de interesses e as relações de dominação, também presentes nas decisões orçamentárias, como pode o Direito Financeiro intervir, influenciar ou mediá-los, rumo a aproximação ao interesse público e rumo a transformações sociais $?^{72}$. Seguramente, pode-se dizer que, de um lado, não está no Direito

sobre a globalidade das rubricas, mas com os pedidos de cada serviço; e) a orçamentação é simplificada, á que a análise recai sobre itens específicos, sem estimar gastos com grandes programas; f) a orçamentação é social, no sentido de que para a aceitação da despesa é decisiva a personalidade de que a propõe; g) a orçamentação é satisfatória, dado que se preocupa com o suficiente (evitar o pior e não buscar o melhor); h) a orçamentação é tratada como se não fosse programática, ou seja, desenvolvem-se os programas sob a forma de ajustamentos monetários marginais ao programas existentes; i) a orçamentação é repetitiva, vez que não se busca resolver os problemas de uma vez por todas, havendo apenas sucessão de problemas; j) a orçamentação é sequencial, porque não se atacam os problemas de uma vez por todas, apenas adia-se, sem uma solução definitiva. (CABRAL, Nazaré da Costa. Programa e decisão orçamental: da racionalidade das decisões orçamentais à racionalidade econômica. Coimbra: Almedina, 2008, pp. 371-373).

${ }^{70}$ CABRAL, Nazaré da Costa. Programa e decisão orçamental: da racionalidade das decisões orçamentais à racionalidade econômica. Coimbra: Almedina, 2008, pp. 373-374.

${ }^{71}$ Ibidem, p. 375.

72 Após as críticas ao orçamento incremental, Nazaré da Costa Cabral também faz questionamento semelhante: "se não é possível no processo de decisão orçamental encontrar qualquer critério racionalizador que permita uma boa orçamentação, se, com ele, nada fica definido, então o que resta ao Orçamento?" 
a solução para todos os problemas advindos desses conflitos; de outro lado, segue-se confiando que através do sistema jurídico é possível alcançar melhores soluções para tais embates. Se não resolvê-los, amenizar os conflitos e as pulsões inerentes à própria natureza humana e que se transpõe ao Estado.

Nessa linha de argumentação, voltando o olhar para os instrumentos de flexibilização orçamentária e o contingenciamento, sugere-se que se a aplicação desses estiver dentro dos limites jurídicos, haverá maior possibilidade de controle, maior transparência e previsibilidade, o que é essencial para uma tentativa de aproximação do gasto público ao interesse público, mesmo que siga havendo interesses privados em jogo. Para que o Direito Financeiro tenha maiores possibilidades de concretização e papel central nas transformações das relações sociais, é fundamental que haja uma aplicação juridicamente mais adequada do contingenciamento (e dos demais instrumentos de flexibilização orçamentária).

Não se pode admitir uma total ineficácia do Direito e sua submissão em relação aos demais sistemas sociais. Até mesmo em uma concepção marxista, na qual a economia (infraestrutura) é o ponto de partida para compreender as demais estruturas sociais (superestrutura), o Direito tinha também sua relevância e influência. Marx e Engels não ignoram a influência dos demais sistemas sociais (sistema jurídico, político e as formas de consciência social) sobre a economia; da superestrutura sobre a infraestrutura ${ }^{73}$.

Segue-se, assim, por uma crença de que o Direito é capaz de promover transformações sociais, ainda que tenha seu espaço limitado. Para tal, não são necessárias aguardar profundas revoluções ou "supercriações" normativas. O caminho, mormente no âmbito do Direito Financeiro, é buscar a concretização da própria Constituição. Conforme afirma Ernesto Garzón Valdés, antes de considerar o direito como um obstáculo às mudanças sociais, deve-se levar as constituições a sério. Antes de se pensar em grandes mudanças nos ordenamentos jurídicos, devemos buscar a vigência plena das normas

(CABRAL, Nazaré da Costa. Programa e decisão orçamental: da racionalidade das decisões orçamentais à racionalidade econômica. Coimbra: Almedina, 2008, pp. 375.)

${ }^{73}$ É importante considerarmos o momento histórico em que os autores escreviam, no qual "havia uma forte corrente idealista que atribuía à vontade e ao pensamento dos homens a causa dos fenômenos sociais, desprezando o papel da vida material" e para contestá-la, muitas vezes caíam no extremo oposto (HARNECKER, Marta. Os conceitos elementais do materialismo histórico. Apresentação de Louis Althusser. Santiago, 1973. p. 93). Por isso que diversas vezes Marx e Engels focalizam e enfatizam ser a economia a estrutura determinante para compreender a sociedade, o que não significa que os elementos da superestrutura não intervêm na infraestrutura. Conforme afirma Engels, "o desenvolvimento político, jurídico, filosófico, religioso, literário, artístico, etc, descansa no desenvolvimento econômico (...) mas todos eles também repercutem uns sobre os outros e sobre a base da necessidade econômica que se impõe sempre, em última instância" (ENGELS, Friedrich. Carta a Starkenburg, de 2 de janeiro de 1984. Disponível em http://www.scientific-socialism.de/FundamentosCartasMarxEngels250194.htm. Acesso em 07/12/2012). 
constitucionais já existentes ${ }^{74}$. Ainda dentro dessa perspectiva, e nas palavras de Regis Fernandes de Oliveira, "o Direito Financeiro pode ser poderosíssimo instrumento de limitação do governante", de diminuição das desigualdades, e propiciar "a amplitude das manifestações da liberdade, esta grande dimensão do ser humano"75.

\subsection{Os instrumentos de flexibilização orçamentária e a concretização do Direito Financeiro}

Além da influência dos interesses e das relações de dominação, os instrumentos de flexibilização orçamentária (em verdade, sua prática) também podem representar um entrave na concretização do Direito Financeiro. De se esclarecer mais uma vez que não se defende a ausência de flexibilidade na condução do gasto público. A flexibilidade é em certa medida essencial. Ocorre que, por suas próprias características, os instrumentos de flexibilização orçamentária são aplicáveis em situações de exceção, em momentos nos quais é necessário flexibilidade. Quando se perde essa premissa, surgem problemas na sua aplicação.

O contingenciamento, instrumento em que se aprofundará este estudo, é enquadrado na categoria de instrumentos ou mecanismos de flexibilização orçamentária. Assim, inclusive para fins de contextualizá-lo, justifica-se adentrar ao tema, sendo necessário primeiramente defini-los.

Os instrumentos de flexibilização orçamentária correspondem a institutos jurídicos que permitem alterações durante a execução do orçamento, seja na previsão de receitas, seja na efetivação das despesas. Pode-se considerar também aqueles mecanismos que permitem excepcionar as regras gerais de Direito Financeiro previstas na Constituição, na Lei de Responsabilidade Fiscal e na Lei $n^{\circ}$ 4.320/64. Trata-se de um conceito que compreende diversos institutos que permitem a remodelação do orçamento, da arrecadação e dos gastos, frente a situações de excepcionalidade, que fogem à regra e à previsibilidade.

Nesse sentido, menciona-se a concepção de José Maurício Conti, segundo o qual o "processo de execução orçamentária é dotado de mecanismos que permitem adaptação da Lei Orçamentária às alterações surgidas ao longo do exercício financeiro, mantendo os

${ }^{74}$ VALDÉS, Ernesto Garzón. Introdución. In: El derecho como objeto e instrumento de transformación. Seminario en Latinoamerica de Teoria Constitucional e Politica (SELA 2002). Buenos Aires: Editores del Puerto, 2003, p. VII.

${ }^{75}$ OLIVEIRA, Regis Fernandes de. Gastos públicos. São Paulo: Editora Revista dos Tribunais, 2012, p. 23. 
objetivos e os programas fixados pelo Poder Público"76. A existência e aplicação de tais mecanismos decorrem, inclusive, do princípio da flexibilidade. O mesmo autor cita, dentre os instrumentos de flexibilização orçamentária, os créditos adicionais, o contingenciamento, a reserva de contingência e a margem de remanejamento.

Adota-se, aqui, um conceito um pouco mais amplo que, além dos mencionados instrumentos, inclui também a desvinculação de receitas. Embora este último não esteja diretamente relacionado à execução orçamentária, também flexibiliza o orçamento, pois excepcionam uma regra geral relativa ao orçamento. Pretende-se aqui uma definição que não esteja relacionada apenas à execução orçamentária, mas também à elaboração orçamentária, razão pela qual é possível a inclusão das desvinculações de receitas.

Nessa linha, também pode ser considerado como instrumento de flexibilização orçamentária o sigilo de despesas. Tem-se como regra a divulgação de dados pelos órgãos públicos. A exceção, ou seja, o sigilo, diz respeito a dados que interferem na segurança da sociedade e do Estado ${ }^{77}$. Nessa linha, atribuir sigilo a uma despesa é constitucional e legalmente possível, mas deve ser encarada como uma exceção à regra do acesso à informação e da transparência ${ }^{78}$.

A pretensão dessa classificação mais ampla é permitir olhar para todos esses instrumentos de flexibilização orçamentária como institutos jurídicos que permitem abertura cognitiva aos sistemas político e econômico ${ }^{79}$, possibilitando, assim, que as

\footnotetext{
${ }^{76}$ CONTI, José Maurício. A autonomia Financeira do Poder Judiciário. São Paulo: MP Editora, 2006, p. 96.

${ }^{77}$ É o que decorre da própria disposição do artigo 5', XXXIII, da Constituição Federal: "todos têm direito a receber dos órgãos públicos informações de seu interesse particular, ou de interesse coletivo ou geral, que serão prestadas no prazo da lei, sob pena de responsabilidade, ressalvadas aquelas cujo sigilo seja imprescindível à segurança da sociedade e do Estado;".

${ }^{78}$ Sobre a parte final do artigo $5^{\circ}$, XXXIII da Constituição Federal e o sigilo das despesas, Fernando Facury Scaff afirma se tratar de uma exceção ao direito à verdade, que não pode ser utilizada de forma indiscriminada, sendo que a classificação de despesas como sigilosas deve ser objeto de análise e julgamento pelo Tribunal de Contas e pelo Parlamento (SCAFF, Fernando Facury. Direitos Fundamentais e Orçamento: despesas sigilosas e o direito à verdade. In CONTI, J. Maurício; SCAFF, Fernando F. (coords.). Orçamentos públicos e direito financeiro. São Paulo: Revista dos Tribunais, 2011, p. 231).

${ }^{79}$ Adota-se aqui o conceito de que o direito, a política e a economia são sistemas sociais operacionalmente autônomos, reproduzidos com base nos seus próprios códigos e critérios, embora condicionados pelos seus meios ambientes respectivos. Tais sistemas seriam dotados, portanto, de fechamento operacional e abertura cognitiva, ou seja, o sistema constitui ele mesmo os elementos de que é composto, diferenciando-se do ambiente em que está inserido, porém, sem se isolar desse ambiente. O direito, como um subsistema social, é dotado de autonomia, proporcionada por sua positivação, o que implica o controle do "código-diferença lícito/ilícito" exclusivamente pelo sistema jurídico, permitindo então seu fechamento operativo. Tal fechamento não significa um isolamento, ao contrário, é o fechamento que permite a abertura cognitiva ao ambiente, ou seja, o sistema jurídico pode assimilar, de acordo com seus critérios, os fatores do ambiente, não sendo diretamente influenciado por esses fatores - "a heterorreferência cognitiva é pressuposto da autoreferência operacional e vice-versa". (Conforme NEVES, Marcelo. Luhmann, Habermas e o Estado de Direito. In: Revista de Cultura e Política, no 37, 1996 e NEVES, Marcelo. A Constitucionalização Simbólica. São Paulo: WMF Martins Fontes, 2007).
} 
finanças públicas alcancem objetivos de política fiscal e econômica, bem como atendam ao programa do governo democraticamente eleito.

Neste passo, não se propõe que o orçamento seja engessado, que não possa ser adaptado a diferentes situações políticas e econômicas. Por outro lado, não se defende que a elaboração e a execução orçamentária sejam feitas fora do Direito. Deve o Direito atuar nesses dois momentos, ao menos estabelecendo seus contornos. O orçamento e os instrumentos de flexibilização, embora possuam também conteúdos político e econômico, não deixam de ser institutos jurídicos. Há, portanto, limites entre os quais os sistemas político e econômico podem influir.

Apresentada uma definição para os instrumentos de flexibilização orçamentária, o que se objetiva é propor uma melhor aplicação dos mesmos, dentro de seus limites jurídicos, o que pode representar significativos avanços na concretização do Direito Financeiro.

Não se pretende adotar uma postura exageradamente formalista (ou positivista) do Direito na interpretação da norma. Ao contrário, se adotada uma visão estritamente positivista do Direito, seria fácil permitir que se criassem instrumentos de flexibilização tanto quanto fosse necessário. Em uma visão estritamente positivista, poder-se-ia ampliar seu âmbito de aplicação quanto fosse desejado, tirando-lhe até seu caráter de exceção.

De outra parte, certamente não se pode abandonar a norma como um elemento relevante dentro do campo jurídico. Deve-se tomá-la dentro do amplo contexto jurídico no qual se encontra, que incluem avaliação de objetivos constitucionais, assim como a busca por um conceito substantivo de justiça, igualmente relevantes. Analisar quais são os espaços deixados a escolhas políticas e econômicas, especialmente no âmbito das Finanças Públicas, são também essenciais ${ }^{80}$. Pretende-se, portanto, na análise e interpretação das normas, relacioná-las com esses demais aspectos.

Nesse sentido, cita-se a proposta de Eros Grau" de utilizar cinco "pautas" essenciais para a análise da Constituição, que podem ser assim resumidas: (i) não se

\footnotetext{
${ }^{80}$ Conforme critica Antônio Alberto Machado "as contradições e carências de uma cultura jurídica impregnada de dogmatismos racionalistas, calcada num positivismo estreito que tende a desconsiderar qualquer indagações a respeito das determinantes socioeconômicas do direito. Portanto, uma cultura jurídica dogmática e autoritária, que forja o saber do jurista a partir de uma ideologia normativo-positivista, sem dúvida hegemônica, baseada apenas numa ordem jurídica confinada em si mesma, a partir daquilo que Kelsen chamou de norma hipotética fundamental, e que não permite qualquer tipo de questionamento sobre a sua legitimidade ou fundamento sócio-histórico". (MACHADO, Antônio Alberto. Ensino jurídico e mudança social. $2^{a}$ ed. São Paulo: Expressão Popular, 2009, p. 27).

${ }^{81}$ GRAU, Eros Roberto. A ordem econômica na Constituição de 1988, 10 a ed. São Paulo; Malheiros, 2005 , pp. 166-169.
} 
interpreta a Constituição em tiras, aos pedaços; (ii) importância das normas-objetivo, que surgem a partir do momento em que os textos normativos passam a ser dinamizados como instrumentos de governo; (iii) importância dos princípios, já que a interpretação da Constituição é dominada pela força dos princípios; (iv) o direito existe em função da sociedade e não a sociedade em função dele; (v) o direito - e, muito especialmente, a Constituição - é não apenas ideologia, mas também nível no qual se opera a cristalização de mensagens ideológicas, razão pela qual as soluções tidas como corretas devem ser adequadas e coerentes com a ideologia constitucionalmente adotada.

Aplicando o raciocínio ao Direito Financeiro, tem-se o seguinte: o âmbito da Constituição (além das leis) que trata da atividade financeira, não pode ser interpretado desconsiderando os fundamentos e objetivos fundamentais da República Federativa do Brasil (artigos $1^{\circ}$ e $3^{\circ}$ da Constituição Federal de 1988), tampouco as garantias e direitos fundamentais (artigos $5^{\circ}$ e $6^{\circ}$ da Constituição Federal). Esses mesmos fundamentos e objetivos devem ser "dinamizados" quando da aplicação das normas de Direito Financeiro: a atividade financeira deve buscar concretizá-los, inclusive pela consideração de princípios, como o da transparência, da motivação dos atos administrativos ou da máxima concretização dos direitos fundamentais, e que condizem com os valores adotados constitucionalmente. E não só, inserem-se no atual paradigma do Direito Financeiro que se tem buscado caracterizar.

A partir dessa concepção, é possível retomar com mais força algumas considerações já feitas no presente capítulo: a concretização do Direito Constitucional Financeiro envolve alcançar maior efetividade dos direitos fundamentais, garantir maior legitimidade democrática, transparência, controle e planejamento do gasto. Reafirma-se: a atividade financeira, dentro de uma ordem constitucional, significa obter recursos e realizar gastos visando dar efetividade à Constituição. Esse contexto deve ser levado em conta na interpretação e aplicação dos instrumentos de flexibilização orçamentária.

Prosseguindo, adentra-se na descrição de cada um dos institutos mencionados, o que permitirá entender as razões pelas quais os instrumentos de flexibilização orçamentária impõem dificuldades na concretização do Direito Financeiro, mormente quando fora de limites e parâmetros jurídicos.

Ressalta-se que o contingenciamento ${ }^{82}$ (mecanismo que permite a limitação de empenho e de movimentação financeira para que se atendam às metas de resultado

82 “Art. 9o. Se verificado, ao final de um bimestre, que a realização da receita poderá não comportar o cumprimento das metas de resultado primário ou nominal estabelecidas no Anexo de Metas Fiscais, os 
estabelecidas pela Lei de Diretrizes Orçamentárias, quando se verificar que a realização de receitas não ocorrerá como prevista) será aprofundado no decorrer do trabalho, por ser justamente o objeto central de análise.

De qualquer modo, importante destacar, desde logo, que esse deve ser utilizado em situação específica, a qual se entende ser excepcional: a não realização das receitas previstas (devido a crises econômicas, por exemplo), permite que o orçamento seja flexibilizado, não sendo executada a despesa estabelecida até que se retorne à situação de "normalidade". Trata-se, por essa razão, de um instrumento de flexibilidade ${ }^{83}$, assim como os demais que passam a ser brevemente descritos.

\subsubsection{Reserva de contingência}

A reserva de contingência representa um montante da lei orçamentária anual destinado ao atendimento de passivos contingentes, riscos e eventos fiscais imprevistos. Como o próprio nome diz, reserva-se uma quantidade de recursos para eventuais contingências que ocorram ao longo do exercício. Sua forma de utilização e os respectivos montantes são previamente determinados pela Lei de Diretrizes Orçamentárias ${ }^{84}$.

Trata-se de uma exceção ao princípio da universalidade e da especificidade, segundo os quais todas as receitas e despesas devem estar previstas em lei (universalidade) e de maneira específica (especificidade). É pressuposto da despesa o detalhamento da fonte e o fim para a qual é destinada. A reserva de contingência, por constar na Lei Orçamentária Anual, é autorizada pelo Legislativo, porém, refere-se a uma autorização genérica, já que o fim a que se destinam aqueles recursos não está previamente determinado. Isto não quer

Poderes e o Ministério Público promoverão, por ato próprio e nos montantes necessários, nos trinta dias subsequentes, limitação de empenho e movimentação financeira, segundo os critérios fixados pela lei de diretrizes orçamentárias.

$\S 1^{\underline{0}}$ No caso de restabelecimento da receita prevista, ainda que parcial, a recomposição das dotações cujos empenhos foram limitados dar-se-á de forma proporcional às reduções efetivadas.

$\S 2^{\underline{0}}$ Não serão objeto de limitação as despesas que constituam obrigações constitucionais e legais do ente, inclusive aquelas destinadas ao pagamento do serviço da dívida, e as ressalvadas pela lei de diretrizes orçamentárias. (...)"

${ }^{83}$ Sobre este aspecto, Alexsandra Katia Dallaverde aponta: "verifica-se que o contingenciamento é um importante instrumento de flexibilização orçamentária nas mãos do Poder Executivo. Nesse aspecto, torna-se de extrema relevância a verificação do método de previsão de receitas adotada, na medida em que se a arrecadação prevista for muito superior àquela efetivamente arrecadada, tal situação irá conferir um poder de flexibilidade orçamentária bastante grande nas mãos do Poder Executivo, que terá ampla margem para o contingenciamento das despesas cuja implementação não seja de seu interesse". (DALLAVERDE, Alexandra Katia. As relações entre os poderes na gestão das Finanças Públicas. Porto Alegre: Nuria Fabris Editora, 2013, p. 140).

${ }^{84}$ Artigo $5^{\circ}$, inciso III, da Lei de Responsabilidade Fiscal. 
dizer que não haja limites: sabe-se que tais recursos devem ser utilizados para dar conta de algum risco fiscal, a exemplo de uma condenação judicial de montante elevado ou a declaração de inconstitucionalidade ou ilegalidade de um determinado tributo.

A própria Lei de Diretrizes Orçamentárias traz um anexo de Riscos Fiscais, cujo objetivo é prever possíveis variações de receitas e despesas, riscos em relação à dívida e riscos relativos a passivos contingentes. Os impactos desses riscos seriam amenizados justamente pela existência da reserva de contingência. Por tal razão, o mecanismo pode ser associado também ao princípio do equilíbrio orçamentário e ao princípio da prudência, norteadores do planejamento.

Interessante notar que, embora a reserva de contingência deva garantir o "atendimento de passivos contingentes, riscos e eventos fiscais imprevistos", parte da reserva de contingência constante do projeto de lei de orçamentária por vezes serve para apropriação em programas incluídos por emenda individual, o que contraria sua própria função, prevista pela Lei de Responsabilidade Fiscal.

O direcionamento da reserva de contingência para emendas parlamentares individuais constou, por exemplo, de forma expressa na Lei de Diretrizes Orçamentárias de $2014^{85}$. A prática relativa à reserva de contingência pode ser extraída também das justificativas constantes na PEC $\mathrm{n}^{\circ}$ 565-A, de 2006, que pretendia incluí-la na Constituição:

Em decorrência do princípio da prudência que deve nortear o planejamento governamental, reafirmado pela LRF em seu art. $5^{\circ}$, quando estabeleceu a necessidade de a Lei Orçamentária Anual - LOA constituir reserva de contingência definida com base na Receita Corrente Líquida RCL, a LDO tem consignado anualmente que o projeto da LOA deva ser encaminhado pelo Poder Executivo ao Congresso Nacional contendo reserva de contingência composta de $2 \%$ (dois por cento) da RCL, o qual deve ser devolvido à sanção presidencial com $1 \%$ (um por cento), significando que a metade da reserva de recursos primários do Orçamento Fiscal encaminhada no projeto dará suporte à intervenção promovida pelo Poder Legislativo quando da aprovação de emendas de iniciativa dos parlamentares, individual ou coletivamente. ${ }^{86}$

\footnotetext{
${ }^{85}$ Lei de Diretrizes Orçamentárias para elaboração da LOA 2014 (Lei no 12.919, de 24/12/2013):

“Art. 13, $\S 3^{\circ}$ A parcela primária da reserva de que trata o caput, equivalente a $1 \%$ da Receita Corrente Líquida, será destinada exclusivamente para apropriação em programações incluídas por emenda individual."

${ }^{86}$ Proposta de Emenda à Constituição no 565-A, de 2006 (do Senado Federal). "Emenda Substitutiva Global (Do Sr. Domingo Sávio e Outros). Justificativa. Disponível em http://www.camara.gov.br/proposicoesWeb/prop_mostrarintegra;jsessionid=3E2ADA80F8FF4F0E660BD61 1B6DF14EE.node1? codteor=1096674\&filename=EMC+18/2013+PEC56506+\%3D\%3E+PEC+565/2006. Acesso em 24/03/2014.
} 
Portanto, embora se configure como mecanismo de flexibilidade orçamentária, essencial para a amenização de "imprevistos" fiscais ocorridos ao longo da execução do orçamento bem como para a preservação de seu equilíbrio, a reserva de contingência tem sido utilizada para garantir a inclusão de emendas parlamentares no orçamento. Abre-se juridicamente um espaço para que motivos econômicos e políticos sejam considerados na condução do gasto público, o que é desejável, mas, na prática, verifica-se uma grave distorção na utilização do mecanismo.

Diante desse quadro, tem-se aqui um exemplo da dificuldade na concretização do Direito Financeiro frente à indevida aplicação de um instrumento de flexibilização orçamentária: como esperar uma adequada execução orçamentária se a reserva de contingência, que deveria ser criada para prevenir impactos fiscais, é utilizada como elemento de negociação entre Executivo e Legislativo? Como esperar uma efetiva participação de um Legislativo que centra sua força na negociação dos recursos da reserva de contingência? Perde-se em planejamento, em legitimidade e em controle.

Trata-se de questão cuja solução não é simples e tampouco é o foco do presente trabalho. Aqui está mencionada apenas a título de exemplo, para demonstrar que a utilização dos instrumentos de flexibilização fora de seus parâmetros jurídicos provoca consequências indesejadas na condução do gasto público.

\subsubsection{Margem de remanejamento}

A margem de remanejamento representa a possibilidade de que um percentual da despesa fixada possa ser remanejado pelo Executivo por decreto, sem necessidade de aprovação específica do Legislativo ${ }^{87}$. Em verdade, trata-se de uma aprovação prévia. Assim, é um mecanismo que flexibiliza a necessidade de que toda alteração orçamentária seja autorizada pelo Legislativo.

Pode-se considerar razoável a fixação de percentuais baixos e que permitam, com urgência e celeridade, que o Executivo faça remanejamentos sem precisar de autorização legislativa. Entretanto, o estabelecimento de percentuais altos de remanejamento seguramente afetam a legitimidade democrática do orçamento, como se verifica em alguns exemplos.

\footnotetext{
${ }^{87}$ Lei ${ }^{\circ}$ 4.320/64:

"Art. $7^{\circ}$ A Lei de Orçamento poderá conter autorização ao Executivo para:

I - Abrir créditos suplementares até determinada importância obedecidas as disposições do artigo 43; (...)"
} 
No Município de São Paulo, houve margem fixada em 15\% nas Leis Orçamentárias Anuais de 2010, 2011 e 2012 ${ }^{88}$, percentual esse que já seria questionável. Entretanto, há relatos de municípios cujo percentual foi fixado em 100\%, distorcendo completamente a função do Legislativo na elaboração do Orçamento ${ }^{89}$. Trata-se de exemplo de abuso na utilização de um instrumento de flexibilização, sem observância de quaisquer parâmetros legais e constitucionais.

Pensar qual o percentual legítimo ou razoável levaria a um amplo debate e, novamente, não é a pretensão deste estudo. Os exemplos servem para levantar questões relativas à concretização do Direito Financeiro: como esperar controle democrático de um orçamento que pode ser (quase) totalmente remanejado pelo Poder Executivo? Por isso que é preciso cautela na utilização da margem de remanejamento, reservando-a a situações limitadas e excepcionais.

\subsubsection{Abertura de créditos adicionais}

Os créditos adicionais são autorizações de despesas ao longo da execução orçamentária, cujos montantes não haviam sido considerados no orçamento inicialmente aprovado (créditos especiais e extraordinários) ou haviam sido dotados de forma insuficiente (créditos suplementares) ${ }^{90}$. Os créditos adicionais são instrumentos de flexibilização porque permitem que sejam fixadas despesas após a edição da Lei Orçamentária, durante o exercício financeiro e, portanto, além do que por ela prevista.

De se esclarecer que os créditos suplementares e especiais são autorizados por lei, tendo, portanto, a anuência do Poder Legislativo. De outra parte, os créditos extraordinários, por se destinarem "a despesas urgentes e imprevistas, em caso de guerra,

\footnotetext{
${ }^{88}$ Conforme informação da Câmara de São Paulo e da Prefeitura de São Paulo (PEREIRA, Juvenal. Entenda como funciona o orçamento municipal. Portal da Câmara Municipal. Disponível em http://www.camara.sp.gov.br/index.php?option=com_content $\&$ view=article \&id=2670:conheca-o-orcamentomunicipal-\&catid=65:materias-especiais\&Itemid=160. Acesso em 08/12/2012), bem como da Lei $\mathrm{n}^{\circ} 15.520$, de 05 de janeiro de 2012 (Lei Orçamentária do Município de São Paulo para o exercício 2012).

89 A exemplo dos Municípios de São Caetano para 2013 (DIÁRIO REGIONAL. Câmara de São Caetano aprova Orçamento para 2013 de R\$ 1,035 bi. Portal do Diário Regional. Disponível em: http://www.diarioregional.com.br/2012/11/28/sua-regiao/politica-abc/politica-sao-caetano-do-sul/camara-desao-caetano-aprova-orcamento-para-2013-de-r-1035-bi/. Acesso em 08/12/2012) e Pindamonhangaba nos anos 90 (FERREIRA, João Sette Whitaker. Apostila didática: alguns elementos de reflexão sobre conceitos básicos de planejamento urbano e urbano-regional. Disponível em: http://www.fau.usp.br/docentes/depprojeto/j_whitaker/aposplan.html. Acesso em 08/12/2012).

90 Artigos 40 a 46 da Lei no $4.320 / 64$.
} 
comoção interna ou calamidade pública", podem ser abertos por medida provisória (ou decreto no caso de Estados e Municípios).

Embora no âmbito federal o Poder Executivo não tenha enfrentado dificuldades para aprovação de créditos especiais e suplementares no Congresso ${ }^{91}$, o problema principal em relação a este mecanismo de flexibilização orçamentária estava centrado nos créditos extraordinários abertos via Medida Provisória, o que afasta o controle pelo Legislativo do manejo orçamentário. Aqui se reiteram as questões já feitas para os demais instrumentos: como esperar legitimidade e controle se é possível ao Executivo abrir créditos extraordinários via Medida Provisória, sem observância dos critérios constitucionais?

Levantamentos demonstram de que entre 2004 e 2007, foram editadas 252 medidas provisórias, sendo que 73 foram editadas para abertura de créditos extraordinários ${ }^{92}$. Os números permitem questionar se, durante esse período, houve tantos casos de comoção interna e calamidade pública (já que guerra não houve).

Diante do constante uso de créditos extraordinários, a (in)constitucionalidade na utilização desse mecanismo foi questionada no Supremo Tribunal Federal, por meio da Ação Direta de Inconstitucionalidade $n^{\circ} 4.048^{93}$, julgada em 2008.

O Supremo Tribunal Federal decidiu, no caso, primeiramente, acerca da possibilidade de o Tribunal "exercer sua função precípua de fiscalização da constitucionalidade das leis e dos atos normativos quando houver um tema ou uma controvérsia constitucional suscitada em abstrato". Esse tema será aprofundado no capítulo seguinte. O segundo aspecto importante se refere ao deferimento da medida cautelar ${ }^{94}$, por considerar inconstitucional a abertura de créditos extraordinários por medida provisória. No caso analisado, os recursos estavam sendo "destinados a prover despesas correntes, que não estão qualificadas pela imprevisibilidade ou pela urgência”, configurando, assim, "um patente desvirtuamento dos parâmetros constitucionais que permitem a edição de medidas provisórias para a abertura de créditos extraordinários", conforme trechos da própria ementa.

\footnotetext{
${ }^{91}$ Conforme DALlAVERDE, Alexandra Katia. As relações entre os poderes na gestão das Finanças Públicas. Porto Alegre: Nuria Fabris Editora, 2013.

${ }^{2}$ Conf. GOMES, Claudia Cristina Aires. O impacto da edição de medidas provisórias no orçamento público. Monografia (especialização). Instituto Serzedello Corrêa, do Tribunal de Contas da União, Centro de Formação, Treinamento e Aperfeiçoamento (Cefor), da Câmara dos Deputados e Universidade do Legislativo Brasileiro (Unilegis), do Senado Federal, Curso de Especialização em Orçamento Público, 2008.

${ }^{93}$ BRASIL. Supremo Tribunal Federal. Pleno. ADI 4.048/DF. Relatora Ministro Gilmar Mendes. Julgamento em 14/05/2008.

${ }^{94}$ Não houve posterior resolução definitiva do mérito, por superveniente perda de objeto.
} 
No citado julgamento, restou demonstrado que, ao menos até aquele momento, havia uma utilização inconstitucional também desse mecanismo de flexibilização orçamentária, também dificultando a concretização do Direito Financeiro, especialmente em relação à participação do Legislativo no controle do gasto público.

De se mencionar, ainda, a indesejada prática de utilização dos créditos adicionais, aliado à reserva de contingência, para aumentar desmedidamente a possibilidade de livre manejo de recursos pelo Executivo. Conforme aponta José Maurício Conti, a partir de exemplo do Estado de São Paulo, "normalmente, atribui-se ao Poder Executivo autorização para abrir créditos suplementares utilizando-se os recursos consignados na dotação a título de reserva de contingência (...), evidenciando um privilégio do Poder Executivo em relação aos demais poderes" ${ }^{\prime 9}$.

1.4.4. Desvinculação de receitas e tredestinação de gastos mínimos obrigatórios

Por último, antes da análise do contingenciamento, apresenta-se mais um importante exemplo sobre o problema na utilização excessiva dos instrumentos de flexibilidade orçamentária. Trata-se da desvinculação de receitas e tredestinação de gastos mínimos obrigatórios, seja por Emenda Constitucional (caso da Desvinculação das Receitas da União - DRU), seja por leis ordinárias (caso da CPMF e CIDE-combustíveis). Explica-se.

Para algumas finalidades constitucionalmente previstas, há normas determinando a realização de gastos mínimos obrigatórios, em percentuais fixados pela própria Constituição ou por leis ordinárias, a exemplo dos gastos mínimos com educação e saúde. Há também tributos cuja característica é a destinação do produto de sua arrecadação a determinadas áreas, a exemplo das contribuições sociais e de intervenção no domínio econômico ${ }^{96}$.

Desta forma, normas que permitam ou determinem a desvinculação dessas receitas ou a não concretização de um gasto mínimo obrigatório representam um instrumento de

\footnotetext{
${ }^{95}$ CONTI, José Maurício. A autonomia Financeira do Poder Judiciário. São Paulo: MP Editora, 2006, p. 97.

${ }^{96} \mathrm{O}$ próprio fundamento para a instituição dessa modalidade de tributo é o financiamento de determinada área para a qual a receita dele arrecada deve ser destinada, do qual são exemplos as contribuições sociais e de intervenção no domínio econômico.
} 
flexibilização orçamentária ${ }^{97}$. Isto porque, os recursos que deveriam ser gastos com uma determinada área são, a partir de uma norma de flexibilização, remanejados para outras áreas e outras finalidades. Se a regra para aquelas receitas é a destinação específica, a sua desvinculação ou tredestinação representa excepcioná-la. Na linha dos demais exemplos, tem-se mais uma vez a abertura do sistema jurídico para que elementos econômicos e políticos fundamentem uma exceção à regra. $\mathrm{O}$ raciocínio ficará mais evidente a partir da análise da Desvinculação das Receitas da União (DRU), instituída e prorrogada via seguidas Emendas Constitucionais e que servirá de exemplo para esta análise.

As “desvinculações" se originaram no âmbito constitucional com a Emenda nº 01 , de 1 de março de 1994, com o nome de Fundo Social de Emergência (FSE), criado com o objetivo de "sanear financeiramente a Fazenda Pública Federal e manter a estabilidade econômica”. Destaque para os motivos econômicos de sua instituição.

Com vigência nos exercícios financeiros de 1994 e 1995, o Fundo possuía, dentre outras fontes de recursos, "vinte por cento do produto da arrecadação de todos os impostos e contribuições da União". Ou seja, vinte por cento da arrecadação, inclusive de contribuições, iria para o Fundo, tredestinando receitas vinculadas. Findo o prazo do FSE, a Emenda Constitucional $n^{\circ}$ 10, de 04 de março de 1996, estabeleceu uma prorrogação, com o nome de Fundo de Estabilização Fiscal (FEF), com vigência até 31 de dezembro de 1997, mantendo a "desvinculação" de $20 \%$.

Por sua vez, a Emenda Constitucional n ${ }^{\circ}$ 17, de 22 de novembro de 1997, prorrogou novamente o fundo, estabelecendo vigência até 31 de dezembro de 1999. Ressalta-se que as prorrogações foram retroativas, de modo que a desvinculação tivesse continuidade de 1994 até 1999.

Em 2000, pela primeira vez com o nome de Desvinculação das Receitas da União (DRU), com o mesmo patamar de $20 \%$, as desvinculações vigeriam pelo período de 2000 a 2003, conforme disposição da Emenda Constitucional no 27 , de 21 de março de $2000^{98}$.

Finalmente, na última década, a DRU foi prorrogada pelas Emendas Constitucionais $n^{\circ}$ 42, de 19 de dezembro de 2003 (vigência da DRU de 2003 a 2007) e pela Emenda Constitucional no 56, de 20 de dezembro de 2007 (vigência de 2008 a 2011).

\footnotetext{
${ }^{97}$ Para uma distinção precisa entre gastos mínimos obrigatórios e receitas vinculadas, vide CARVALHO, André Castro. Vinculação de Receitas Públicas. São Paulo: Quartier Latin, 2010, p. 118.

98 SCAFF, Fernando Facury. Direitos Humanos e a Desvinculação das Receitas da União - DRU. In: Octávio Campos Fischer. (Org.). Tributos e Direitos Fundamentais. $1^{\text {a }}$ ed. São Paulo: Dialética, 2004, p. 6379.
} 
E mais recentemente, a Emenda Constitucional $n^{\circ}$ 68, de 21 de dezembro de 2011 prorrogou sua vigência até 2015 .

A atual redação dada ao artigo 76 do ADCT pela Emenda Constitucional $n^{\circ}$ 68/2011 determina que "são desvinculados de órgão, fundo ou despesa, até 31 de dezembro de 2015, 20\% (vinte por cento) da arrecadação da União de impostos, contribuições sociais e de intervenção no domínio econômico, já instituídos ou que vierem a ser criados até a referida data, seus adicionais e respectivos acréscimos legais".

Importante esclarecer que os parágrafos do referido artigo "protegeram" as transferências a Estados, Distrito Federal e Municípios, a arrecadação da contribuição social do salário-educação e os recursos mínimos obrigatórios para manutenção e desenvolvimento do ensino, excetuando-os dos efeitos da DRU ${ }^{99}$.

As justificativas para a DRU, atualmente dadas pelo Ministério do Planejamento, Orçamento e Gestão, apontam para o seguinte:

O excesso de vinculações no Orçamento Geral da União cresceu nos últimos anos, o que levou a União a se endividar no mercado para pagamento de despesas obrigatórias quando dispunha de recursos sobrando em outros itens. (...) A DRU objetiva tão somente dar uma maior flexibilidade à alocação dos recursos públicos e não significa elevação das receitas disponíveis para o governo federal. Além disso, não afeta as transferências constitucionais para Estados e municípios, cuja principal fonte de receita é o IPI e o Imposto de Renda, uma vez que a desvinculação é feita após os cálculos das transferências ${ }^{100}$.

Em suma, as principais razões para criação e prorrogações da DRU são, portanto, a sobra de recursos em alguns itens e o suposto "engessamento" do orçamento. Veja-se que a DRU visa reduzir o referido "engessamento", daí também decorrer sua classificação como um instrumento de flexibilização orçamentária.

Sobre as funções do referido mecanismo, Marcos José Mendes aponta que o engessamento do orçamento culmina na "virtual impossibilidade de se fazer grandes ajustes orçamentários de curto-prazo", tendo a DRU uma "função fundamental de permitir

\footnotetext{
99 "Art. 76. (...)

$\S 1^{\circ} \mathrm{O}$ disposto no caput não reduzirá a base de cálculo das transferências a Estados, Distrito Federal e Municípios, na forma do $\S 5^{\circ}$ do art. 153, do inciso I do art. 157, dos incisos I e II do art. 158 e das alíneas $a, b$ e $d$ do inciso I e do inciso II do art. 159 da Constituição Federal, nem a base de cálculo das destinações a que se refere a alínea $c$ do inciso I do art. 159 da Constituição Federal.

$\S 2^{\circ}$ Excetua-se da desvinculação de que trata o caput a arrecadação da contribuição social do salárioeducação a que se refere o $\S 5^{\circ}$ do art. 212 da Constituição Federal.

$\S 3^{\circ}$ Para efeito do cálculo dos recursos para manutenção e desenvolvimento do ensino de que trata o art. 212 da Constituição Federal, o percentual referido no caput será nulo."

${ }^{100}$ BRASIL. Ministério do Planejamento, Orçamento em Gestão. Informações Orçamentárias. Desvinculação das Receitas da União. Disponível em http://www.planejamento.gov.br/editoria.asp?p=imprensa\&ler=t478. Acesso em 24/03/2014.
} 
o uso de contribuições sociais e econômicas (que deveriam ser aplicadas em despesas às quais estão vinculadas) no pagamento da dívida pública e no financiamento de outras despesas" ${ }^{\prime 101}$.

A utilização de recursos vinculados a finalidades constitucionalmente previstas para o pagamento da dívida pública também é constatado por Fernando Facury Scaff, razão pela qual este autor entende inclusive ser a DRU um mecanismo inconstitucional ${ }^{102}$.

Igualmente aos demais instrumentos de flexibilização, tem-se a retirada do objetivo geral estabelecido pelo Direito e pela Constituição Federal (destinação de recursos a áreas específicas) por uma razão primordialmente de política econômica (no caso o pagamento dos juros da dívida). Para esse exemplo, entretanto, há uma diferença para os demais instrumentos citados que, por si só (abstratamente), não se mostram inconstitucionais. Não é o caso da DRU, especialmente de suas seguidas prorrogações, conforme as razões abaixo descritas.

Em primeiro lugar, o fato de ter sido instituída por Emenda Constitucional não impede considerá-la inconstitucional. Há que se partir da premissa, já adotada pelo Supremo Tribunal Federal, de que as emendas à Constituição podem ser objeto de controle de constitucionalidade ${ }^{103}$. Deve-se afastar, portanto, o argumento de que por ter sido introduzida por uma Emenda Constitucional, a DRU não poderia ser considerada inconstitucional, na linha do que já decidiu o Supremo.

Quanto ao mérito da medida, verifica-se que as desvinculações acabaram por retirar parte dos recursos cuja Constituição obrigatoriamente destinava a determinadas áreas determinadas, especialmente sociais, como saúde, educação, seguridade social, etc. Tratase de recursos mínimos (e receitas vinculadas) que, na lógica constitucional, deveriam ser garantidos para financiar o extenso rol de direitos sociais fundamentais. Ao permitir a não aplicação dos recursos vinculados a essas áreas e possibilitar sua utilização para fins que não os constitucionalmente previstos, as seguidas desvinculações não apenas subverteram a lógica constitucional, mas também, conforme defende Fernando Facury Scaff, "afastaram vastamente a concretização dos direitos humanos (ou, como deseja parte da doutrina, dos

\footnotetext{
101 MENDES, Marcos J. Sistema orçamentário brasileiro: planejamento, equilíbrio fiscal e qualidade do gasto público. Texto para discussão 39. Brasília: Consultoria Legislativa do Senado Federal, 2008, p. 32-34.

102 SCAFF, Fernando facury. Direitos Humanos e a Desvinculação das Receitas da União - DRU. In: Octávio Campos Fischer. (Org.). Tributos e Direitos Fundamentais. $1^{\mathrm{a}}$ ed. São Paulo: Dialética, 2004.

${ }^{103}$ Dentre outros julgados, menciona-se o seguinte: BRASIL. Supremo Tribunal Federal. Pleno. Ação Direta de Inconstitucionalidade no 939/DF. Relator Ministro Sydney Sanches. Julgamento em 15/12/1993. Na mencionada ação, o Tribunal entendeu que "uma emenda constitucional emanada, portanto, do constituinte derivado, incidindo em violação à Constituição originária, pode ser declarada inconstitucional, pelo Supremo Tribunal Federal, cuja função precípua é de guarda da Constituição.
} 
direitos fundamentais sociais) por falta de recursos para sua implementação, destinados a outras finalidades"

A posição não é unânime na doutrina. Cita-se, por exemplo, o raciocínio proposto por Marcelo Guerra Martins ${ }^{105}$, que buscou defender a constitucionalidade de DRU, a partir de um teste de proporcionalidade. Segundo o autor, a medida (i) é adequada, uma vez que as receitas estão "vinculadas" por força de norma constitucional, e a alteração via Emenda mostra-se adequada, por ser norma de igual hierarquia; (ii) é necessária, pois o resultado advindo com a desvinculação dificilmente seria alcançado por outro meio (reforma fiscal ampla é o ideal mas é faticamente inviável); (iii) atende à proporcionalidade em sentido estrito (“custo-benefício"), já que é preciso gerar superavit primário e manter regularidade nos pagamentos aos credores da dívida pública, sob pena de risco de recessão econômica, além de que uma parcela das receitas continua sendo aplicada com saúde e educação (a "desvinculação" não seria total).

Discorda-se dessa posição. Em breves linhas, entende-se que (i) por se tratar de modificação constitucional que atinge especialmente direitos fundamentais sociais, a alteração não se mostra adequada, sequer via emenda à Constituição; (ii) a supressão de direitos fundamentais (especialmente sociais) não pode ser justificada pela dificuldade fática de se realizar reformas profundas no sistema fiscal; (iii) a geração de superavit primário e o pagamento de credores, embora economicamente importante, não pode subverter a imposição constitucional de proteção e implementação dos direitos fundamentais sociais - o benefício gerado pela regularidade nos pagamentos dos credores não podem compensar o custo da não implementação dos direitos sociais - a Constituição atribuiu pesos distintos a tais objetivos.

Ademais, de se acrescentar que o alegado problema da rigidez orçamentária é apenas resolvido parcial e transitoriamente. Neste passo, Fernando Facury Scaff explica que a 'flexibilização' do orçamento, quando necessária, pode não implicar em uma violação constitucional, "podendo ser feita através da desvinculação estabelecida nas leis ordinárias, ou mesmo através de outras normas que possibilitem o uso de eventuais saldos (desde que não contingenciados de maneira irregular)" ${ }^{\text {106. }}$.

104 SCAFF, Fernando facury. Direitos Humanos e a Desvinculação das Receitas da União - DRU. In: Octávio Campos Fischer. (Org.). Tributos e Direitos Fundamentais. $1^{a}$ ed. São Paulo: Dialética, 2004, p. 77.

${ }^{105}$ MARTINS, Marcelo Guerra. As vinculações das receitas públicas no orçamento. A Desvinculação das Receitas da União (DRU). As contribuições e a referibilidade. In CONTI, J. Maurício; SCAFF, Fernando F. (coords.). Orçamentos públicos e direito financeiro. São Paulo: Revista dos Tribunais, 2011, pp. 821-845.

106 SCAFF, Fernando facury. Direitos Humanos e a Desvinculação das Receitas da União - DRU. In: Octávio Campos Fischer. (Org.). Tributos e Direitos Fundamentais. 1ª ed. São Paulo: Dialética, 2004, p. 77. 
Em suma, a Desvinculação das Receitas da União tem sido utilizada como um instrumento de flexibilização orçamentária quase desde a vigência da Constituição. Tornou-se regra e não mais exceção. Subverte os objetivos constitucionais desde o início ou, como bem aponta Fernando Facury Scaff, sob o escudo da tese da ingovernabilidade financeira, "ameaça à concretização constitucional desde a promulgação"107.

Por fim, merecem menção as desvinculações veiculadas não através da DRU, mas mediante normas infraconstitucionais (inclusive orçamentárias) que tredestinam receitas de contribuições. São os casos, por exemplo, da $\mathrm{CPMF}^{108}$ e da CIDE-combustíveis. Essa última foi objeto de apreciação pelo Supremo Tribunal Federal, na Ação Direta de Inconstitucionalidade $2.925^{109}$, adiante aprofundada. Nesse julgamento, entendeu-se ser inconstitucional a interpretação da lei orçamentária que permite a abertura de crédito suplementar em rubrica estranha à destinação específica da CIDE-combustíveis prevista na Constituição Federal (artigo 177, §4º , da Constituição Federal).

Portanto, mesmo com o entendimento sobre a inconstitucionalidade dessa potencial tredestinação, fato é que outras desvinculações prosseguem sendo instituídas. Nessa linha, reitera-se o que já concluído para os demais instrumentos de flexibilização orçamentária: ainda que remanejamentos e adaptações orçamentárias sejam importantes para a política fiscal e econômica, não se pode aceitar como juridicamente válido um instrumento, criado para ser "provisório", mas reeditado há mais de quinze anos, que tredestina recursos para os quais a própria Constituição fixa finalidade específica. Impede-se a concretização constitucional do Direito Financeiro, mormente na finalidade de implementação dos direitos fundamentais.

\footnotetext{
${ }^{107}$ Ibidem, p. 79.

108 Conforme estudo de SANTI, Eurico Marcos Diniz De; PISCITELLI, Tathiane dos Santos. Análise da destinação dos recursos da CPMF no período de 2001 a 2006. p. 09-31.

${ }^{109}$ BRASIL. Supremo Tribunal Federal. Pleno. ADI 2.925/DF. Relatora Ministra Ellen Gracie. Relator para acórdão Ministro Marco Aurélio. Julgamento 19/12/2003.
} 


\section{ASPECTOS TEÓRICOS DO CONTINGENCIAMENTO: ANÁLISE DO ARTIGO 9 DA LEI DE RESPONSABILIDADE FISCAL}

\subsection{Aspectos introdutórios: do planejamento à execução orçamentária}

No presente capítulo, adentra-se no estudo do mecanismo de flexibilização orçamentária objeto do presente trabalho - o contingenciamento. Busca-se uma análise pormenorizada da norma que o prevê: o artigo $9^{\circ}$ da Lei da Responsabilidade Fiscal. Porteriormente, fazem-se alguns apontamentos sobre a ilegalidade e inconstitucionalidade de sua prática ${ }^{110}$.

É preciso dizer que o contingenciamento está inserido na execução do orçamento, nele interferindo, razão pela qual é importante que se façam algumas notas sobre o processo orçamentário, visando contextualizar o instrumento objeto de estudo.

Desde a Constituição Federal de 1988, o processo orçamentário é integrado por três espécies de "leis" ou por três fases: o Plano Plurianual (PPA), a Lei de Diretrizes Orçamentárias (LDO) e a Lei Orçamentária Anual (LOA).

O Plano Plurianual (PPA) é o instrumento mediante o qual será estabelecido, “de forma regionalizada, as diretrizes, objetivos e metas da administração pública federal para as despesas de capital e outras delas decorrentes e para as relativas aos programas de duração continuada"111. O plano plurianual envolve a delimitação dos investimentos, inversões financeiras e transferências de capital ("despesas de capital") ${ }^{112}$, bem como dos gastos cuja execução ultrapassa o exercício financeiro ${ }^{113}$. Trata-se, ao menos em parte, do

\footnotetext{
${ }^{110}$ Reitera-se que não se pretende questionar a norma em abstrato, mas a aplicação desta norma, ou seja, os decretos de contingenciamento.

${ }_{111}$ Artigo $165, \S 1^{\circ}$ da Constituição Federal.

${ }^{112}$ Lei ${ }^{\circ} 4.320 / 64$ :

“Artigo 12 (...)

$\S 4^{\circ}$ Classificam-se como investimentos as dotações para o planejamento e a execução de obras, inclusive as destinadas à aquisição de imóveis considerados necessários à realização destas últimas, bem como para os programas especiais de trabalho, aquisição de instalações, equipamentos e material permanente e constituição ou aumento do capital de emprêsas que não sejam de caráter comercial ou financeiro.

$\S 5^{\circ}$ Classificam-se como Inversões Financeiras as dotações destinadas a:

I - aquisição de imóveis, ou de bens de capital já em utilização;

II - aquisição de títulos representativos do capital de emprêsas ou entidades de qualquer espécie, já constituídas, quando a operação não importe aumento do capital;

III - constituição ou aumento do capital de entidades ou emprêsas que visem a objetivos comerciais ou financeiros, inclusive operações bancárias ou de seguros.

$\S 6^{\circ}$ São Transferências de Capital as dotações para investimentos ou inversões financeiras que outras pessoas de direito público ou privado devam realizar, independentemente de contraprestação direta em bens ou serviços, constituindo essas transferências auxílios ou contribuições, segundo derivem diretamente da Lei de Orçamento ou de lei especialmente anterior, bem como as dotações para amortização da dívida pública."

${ }^{113}$ Artigo 167, $\S 1^{\circ}$ da Constituição Federal.
} 
"desdobramento do orçamento-programa"114; da lei que prevê as despesas de mais longo prazo e, por decorrência, "baliza para os planos e programas nacionais, regionais e setoriais $\left(\mathrm{CF}\right.$, art. $\left.165, \S 4^{\circ}\right)$, exercendo papel fundamental no planejamento das políticas públicas que visem reduzir as desigualdades sociais e regionais, em cumprimento a um dos objetivos fundamentais previstos no art. $3^{\circ}$ da Constituição (inciso III)" ${ }^{\prime 115}$.

Concretizando o planejamento apresentado no PPA, a Lei de Diretrizes Orçamentárias (LDO) estabelecerá as "metas e prioridades da administração pública federal, incluindo as despesas de capital para o exercício financeiro subsequente, orientará a elaboração da lei orçamentária anual, disporá sobre as alterações na legislação tributária (...)"116. A LDO é essencial para a execução orçamentária, já que especifica quais objetivos do Plano Plurianual serão efetuados no exercício seguinte. Ademais, prevê os Anexos de Metas e de Riscos Fiscais, fundamentais para a manutenção do equilíbrio orçamentário.

O Anexo de Metas Fiscais é de grande relevância para a análise do contingenciamento. É nele que se fixam os resultados nominal e primário, cujo cumprimento, se ameaçado, permite a utilização do contingenciamento. Cabem aqui algumas definições.

O resultado nominal é a diferença de todas as receitas e despesas; ao passo que o resultado primário representa a diferença entre receita e despesa, excluídos os juros e o principal da dívida (pago e recebido). Para o resultado primário, "apura-se o quanto ingressou de receita, a qualquer título, e abatem-se eventuais operações de crédito, restos a pagar, receitas obtidas com aplicações financeiras e despesas empenhadas"117. Se o saldo é positivo, haverá superavit primário, elemento da política fiscal e econômica de intensa discussão e que influencia diretamente o contingenciamento, o que será tratado na análise dos dados.

Na Lei de Diretrizes Orçamentárias são trazidos também os “critérios e formas de limitação de empenho", ou seja, é também fonte de limite para o contingenciamento no exercício a que se refere ${ }^{118}$.

\footnotetext{
${ }^{114}$ OLIVEIRA, Regis Fernandes de. Curso de direito financeiro. $4^{\mathrm{a}}$ ed., ver., atual e ampliada. São Paulo: Revista dos Tribunais, 2011, p. 386.

${ }^{115}$ CONTI, José Maurício. Planejamento e Responsabilidade Fiscal. In SCAFF, Fernando Facury; CONTI, José Maurício. Lei de Responsabilidade Fiscal - 10 anos de Vigência - Questões Atuais. Florianópolis: Conceito Editorial, 2010, p. 45).

${ }_{116}$ Artigo 165, § $2^{\circ}$ da Constituição Federal.

${ }^{117}$ OLIVEIRA, Regis Fernandes de. Curso de direito financeiro. $4^{\mathrm{a}}$ ed., ver., atual e ampliada. São Paulo: Revista dos Tribunais, 2011, p. 390.

${ }^{118}$ Artigo $4^{\circ}$, I, b, da Lei de Responsabilidade Fiscal.
} 
Cita-se, ainda, que a Lei de Diretrizes Orçamentárias é relevante por estabelecer "normas relativas ao controle de custos e à avaliação dos resultados dos programas financiados com recursos orçamentários", conforme disposto no artigo $4^{\circ}, \mathrm{I}, e$, da Lei de Responsabilidade Fiscal, aspectos essenciais para a execução orçamentária.

Em suma, as disposições que devem ser trazidas pela Lei de Diretrizes Orçamentárias estão intimamente relacionadas ao contingenciamento, seja por trazer critérios para sua aplicação no exercício, seja por trazer as metas que, em parte, nortearão sua aplicação.

Finalmente, concretizando o planejamento do PPA e da LDO, tem-se a Lei Orçamentária Anual (LOA), que é o instrumento de maior especificidade e trará a previsão de receitas e a fixação de despesas para o exercício financeiro seguinte. Consolidado o planejamento com a LOA, finda-se a fase de elaboração orçamentária e, com o início do exercício, começa-se a execução orçamentária.

A execução do orçamento, ao menos no tocante às despesas contratuais, dá-se em quatro fases: (i) empenho, (ii) liquidação, (iii) ordem de pagamento e (iv) pagamento.

Nos termos do artigo 58 da Lei $n^{\circ} 4.320 / 64$, o empenho é o ato emanado da autoridade competente que cria para o Estado a obrigação de pagamento, pendente ou não de implemento de condição. A despeito de a lei falar em "obrigação de pagamento", há ainda três etapas a serem seguidas e requisitos a serem cumpridos até que a despesa empenhada se converta no efetivo pagamento. De qualquer modo, o empenho representa o ato por meio do qual se enquadra a despesa em determinado crédito orçamentário, deduzindo-a do montante total. Ademais, o empenho funciona também como uma garantia ao credor de que os valores contratados tenham previsão orçamentária.

O empenho será diretamente afetado pelo contingenciamento, razão pela qual este é também denominado de "limitação de empenho". Embora prevista a despesa, não ocorre o empenho e não se executa o orçamento.

Efetuado o empenho, a fase seguinte da execução da despesa é a liquidação, a qual consiste na verificação do direito adquirido pelo credor tendo por base os títulos e documentos comprobatórios do respectivo crédito. Na liquidação, verifica-se a origem e o objeto do pagamento, o montante e o sujeito a quem deve ser pago. Na liquidação, pode-se fazer não apenas uma conferência formal, sendo possível a verificação física do 
cumprimento do que foi contratado - se o serviço foi efetivamente prestado ou o material entregue, por exemplo ${ }^{119}$.

Após o empenho e a liquidação da despesa, é expedida, via despacho, a ordem de pagamento, que determina que a despesa seja paga. A ordem de pagamento somente poderá ser exarada em documentos processados pelos serviços de contabilidade, conforme prevê o artigo 64, parágrafo único, da Lei $n^{\circ}$ 4.320/64. Por fim, emitida a ordem, é efetuado o pagamento, seja por ordem bancária ou por cheque nominativo contabilizado pelo órgão competente. O pagamento é obrigatoriamente assinado pelo ordenador da despesa e pelo encarregado do setor financeiro ${ }^{120}$.

O contingenciamento influirá também nesses outros momentos da execução, já que além da limitação de empenho, tal mecanismo pode limitar a "movimentação financeira". Impedem-se, assim, as outras etapas da execução orçamentária, gerando o que se denomina restos a pagar: despesas empenhadas mas não pagas até o final do exercício ${ }^{121}$.

De se esclarecer que limitar o empenho ou a movimentação financeira não significa cancelamento das despesas contratadas, mas apenas adiamento do seu pagamento. Como observa Regis Fernandes de Oliveira, a partir do empenho gera-se uma justa expectativa de recebimento do montante devido, razão pela qual este apenas pode ser cancelado se houver nulidade superveniente - "se o empenho ocorreu de forma legal, não há como se efetuar seu cancelamento" $" 122$.

Além do rito estabelecido pela Lei $n^{\circ} 4.320 / 64$, o gasto público segue também uma programação financeira durante o exercício. Conforme estabelecido pelo artigo $8^{\circ}$ da Lei de Responsabilidade Fiscal ${ }^{123}$, após a elaboração e publicação da Lei Orçamentária Anual, deve o Poder Executivo, em até 30 dias, estabelecer a programação financeira e o cronograma de execução mensal de desembolso. A programação financeira é implementada via decreto e "justifica-se até mesmo pelo fato de a receita ser apurada gradualmente ao longo do exercício, em patamares variáveis, criando a necessidade inafastável de que também a despesa seja escalonada" ${ }^{\prime 24}$. Isto é, como a receita é prevista,

\footnotetext{
119 Artigo 63 da Lei $n^{\circ} 4.320 / 64$.

${ }^{120}$ Artigo 74, do Decreto-Lei 200/67.

${ }^{121}$ Artigo 36 da da Lei no 4.320/64.

122 OLIVEIRA, Regis Fernandes de. Curso de direito financeiro. $4^{\mathrm{a}}$ ed., ver., atual e ampliada. São Paulo: Revista dos Tribunais, 2011, p. 327.

123 “Art. $8^{-}$Até trinta dias após a publicação dos orçamentos, nos termos em que dispuser a lei de diretrizes orçamentárias e observado o disposto na alínea $c$ do inciso I do art. 4º , o Poder Executivo estabelecerá a programação financeira e o cronograma de execução mensal de desembolso."

${ }^{124}$ MENDONÇA, Eduardo Bastos Furtado de. Constitucionalização das Finanças Públicas no Brasil. Rio de Janeiro: Renovar, 2010, p. 91
} 
e não é arrecadada toda em janeiro, é preciso que o gasto seja ajustado conforme vão ocorrendo os ingressos. Nos termos do artigo 17 do Decreto-Lei n ${ }^{0}$ 200/67, a programação tem por função "ajustar o ritmo de execução do orçamento-programa ao fluxo provável de recursos".

Ressalta-se que essa previsão de receitas que se pretende arrecadar durante o exercício (não é a receita arrecada) trazida no orçamento anual é calculada conforme variáveis econômicas, políticas e jurídicas futuras. Envolve, por exemplo, a previsão da arrecadação de tributos, cujo montante é diretamente influenciado por indicadores de mercado, tais como juros, inflação, crescimento, nível de endividamento, além de conjunturas políticas $^{125}$. Ainda, durante a execução, deve o gestor público respeitar as já referidas metas fiscais da Lei de Diretrizes Orçamentárias, imputando ainda mais relevância ao decreto de programação financeira.

É exatamente nesse contexto que se insere a possibilidade de contingenciamento, ou seja, de limitar o empenho e a movimentação financeira. Essa possibilidade de contingenciar as despesas fixadas e o próprio fato de as receitas serem previstas no orçamento (e não já arrecadadas) traz à tona a questão se é a lei orçamentária meramente autorizativa? Ou, ainda, se se trata de lei meramente formal, por não conter uma efetiva obrigação jurídica? Responder essas perguntas é fundamental para entender o contingenciamento. É o que se faz no item seguinte.

\subsection{O antigo debate sobre a natureza e os efeitos da lei orçamentária: lei formal vs. lei material e orçamento autorizativo vs. orçamento impositivo}

Há muito se discute sobre a natureza e os efeitos da lei orçamentária. De um lado, há o entendimento de que o orçamento é uma lei formal, com conteúdo de mero ato administrativo, sendo as despesas nele fixadas apenas autorizativas. Essa corrente fundamenta seu ponto de vista na necessidade de haver liberdade na gestão de recursos, bem como nas características específicas e temporais da lei orçamentária. Envolve, ainda, uma argumentação histórica, adiante apresentada.

De outro lado, está a concepção de que a lei orçamentária é lei em sentido material e formal, com a execução necessária das despesas fixadas, ressalvadas situações excepcionais. Essa última corrente se justifica, em primeiro lugar, pela ausência de

${ }^{125}$ CONTI, José Maurício. A autonomia Financeira do Poder Judiciário. São Paulo: MP Editora, 2006, p. 79. 
elementos no ordenamento jurídico que fundamentem a distinção entre lei formal e lei material - não há previsão normativa de lei formal ou lei material, mas lei como lei. Em segundo lugar, porque a lei orçamentária, por ser como as demais leis, é impositiva, ressalvadas as permissões legais para a sua inexecução e para que seja excepcionada.

No presente trabalho, adere-se a esta segunda concepção: o orçamento é lei (em sentido material e formal) e de execução impositiva. Sem essa premissa, toda a argumentação que se segue careceria de sentido lógico.

Antes de contrapor de forma mais profunda os argumentos de cada corrente, é preciso fazer a seguinte ressalva, muito bem observada por Eduardo Furtado Bastos de Mendonça: a associação entre lei formal e orçamento autorizativo, de um lado, e, de outro lado, lei material e orçamento impositivo, "costumam ser apresentadas como se houvesse necessária implicação lógica entre eles”. Para o mencionado autor, entretanto, tal associação não parece correta, uma vez que, ainda que se admita que o orçamento tenha "conteúdo materialmente administrativo, não há motivos para presumir que se trata de mera autorização", inclusive porque os atos administrativos são de observância obrigatória $^{126}$. No presente item, para que os argumentos sejam adequadamente contrapostos, será explicitado, primeiro, que a lei orçamentária é lei material (e não mera lei formal) e, segundo, que é impositiva (e não autorizativa).

A caracterização do orçamento como lei formal remonta ao jurista Paul Laband, a quem coube influência decisiva na controvérsia da natureza do orçamento - em debate que ocorria na Alemanha no final do século XIX e que se estendeu ao início do século XX. Conforme resume Francisco Campos, "a doutrina de Laband consiste em despir o orçamento de qualquer significação jurídica, considerando-o tão somente como um expediente de ordem prática, destinado a pôr ordem na Administração" ${ }^{127}$.

Alvaro Bereijo explica que Laband possuía um método positivista e formalista, livre dos aspectos históricos, políticos e filosóficos, que para ele não importavam para a dogmática do Direito. Para Laband, o Direito se esgota nas normas jurídicas, devendo o jurista se ocupar somente delas. Nessa linha, conclui Bereijo sobre a doutrina de Laband: "na ideia de Estado de Direito da doutrina alemã estava implícito o propósito de fazer do

\footnotetext{
${ }^{126}$ MENDONÇA, Eduardo Bastos Furtado de. Constitucionalização das Finanças Públicas no Brasil. Rio de Janeiro: Renovar, 2010, p. 74, nota de rodapé 128.

${ }^{127}$ CAMPOS, Francisco. Orçamento - Natureza jurídica. In: Revista de Direito Administrativo 71/324.
} 
Direito uma realidade autônoma, separada da política (...) apartando do Estado de Direito todo elemento que não seja estritamente jurídico"128.

Essa concepção foi decisiva para a teoria jurídica sobre o orçamento elaborada por Laband, desenvolvida em torno de uma questão-chave: era a lei orçamentária quem dava ao governo o direito constitucional e obrigatório de arrecadar e realizar os gastos? Ou, ainda, na ausência da lei orçamentária, a continuidade da Administração se tornaria ilegal? ${ }^{129}$

Para responder à questão, Laband parte da mencionada distinção entre lei em sentido material, que contém efetivamente uma norma jurídica (declara uma regra de direito, aplicável a uma situação de fato) e lei em sentido formal, aquela que expressa uma mera constatação de acordo de vontades entre Rei e Parlamento (Executivo e Legislativo), mas que não contém nenhuma manifestação de vontade do Estado em declarar ou estabelecer uma regra de direito ${ }^{130}$.

Para a teoria de Laband, o orçamento é caracterizado como uma lei formal, ou ainda, um ato da administração que a Constituição determina que assuma a forma e a solenidade de lei. Essa lei, porém, não traz regra jurídica, proibição ou preceito jurídico. Ao contrário, o orçamento simplesmente estabelece uma relação política entre Governo e parlamento. Dessa concepção decorrem as seguintes consequências: (i) o orçamento não é uma autorização para recolher as receitas e efetuar as despesas, já que pode o Governo fazê-lo, ainda que estas não constem do orçamento; (ii) as derrogações ao orçamento não constituem infrações jurídicas; e (iii) o orçamento é apenas um plano de gestão, um programa de administração, com sentido meramente político ${ }^{131}$.

O entendimento de Laband sobre a natureza do orçamento influenciou doutrinas em todo o mundo e foi, inclusive, a concepção adotada pelo Supremo Tribunal Federal em alguns julgamentos.

Cita-se, por exemplo, o julgamento da Ação Direta de Inconstitucionalidade $\mathrm{n}^{\circ}$ $1.640^{132}$, em 1998, no qual o Supremo Tribunal Federal decidiu ser a lei orçamentária uma "lei formal, de natureza e efeitos político-administrativos concretos". Na referida ação, discutia-se a não destinação de recursos oriundos da CMPF para ações de saúde, conforme

\footnotetext{
${ }^{128}$ BEREIJO, Alvaro R. Estudio preliminar. In LABAND, Paul. Derecho presupuestario. Madrid: Instituto de Estudios Fiscales, 1979, pp. XLII/XLIII.

${ }^{129}$ Ibidem, p. L.

${ }^{130}$ Ibidem, p. LII.

131 CAMPOS, Francisco. Orçamento - Natureza jurídica. In: Revista de Direito Administrativo 71/324, jan./mar. 1963. p. 326.

${ }^{132}$ BRASIL. Supremo Tribunal Federal. Pleno. ADI 1640 QO. Relator Ministro Sydney Sanches. Julgamento em 12/02/1998.
} 
se previa na Constituição (artigo 74, $\S 3^{\circ}$ do ADCT, com redação da Emenda Constitucional $n^{\circ}$ 12/96). Veja-se que não somente houve a classificação do orçamento como lei formal, mas, em decorrência, a impossibilidade de se exercer o controle de constitucionalidade.

Essa posição do Supremo Tribunal Federal sobre o controle de constitucionalidade começou a ser modificada em 2003, a partir do julgamento da Ação Direta de Inconstitucionalidade $\mathrm{n}^{\mathrm{o}} 2.925^{133}$. No caso, foi admitido o controle concentrado de lei orçamentária, a partir do seguinte fundamento: “(...) mostra-se adequado o controle concentrado de constitucionalidade quando a lei orçamentária revela contornos abstratos e autônomos, em abandono ao campo da eficácia concreta".

Percebe-se que não se tratava exatamente de uma mudança de perspectiva sobre a natureza da lei orçamentária, mas somente do papel do Tribunal, que poderia exercer o controle a depender dos efeitos questionados no caso em questão. Na ADI $n^{\circ} 2.295$, a discussão cingia-se à possibilidade de se aplicar recursos da CIDE-combustíveis para finalidade distinta daquela prevista constitucionalmente. A decisão, já mencionada neste trabalho, foi no sentido de que é inconstitucional a interpretação da lei orçamentária que permite a abertura de crédito suplementar em rubrica estranha à destinação da CIDEcombustíveis, prevista na Constituição Federal (artigo 177, §4º da Constituição Federal).

Por fïm, a Ação Direta de Inconstitucionalidade $n^{\circ} 4.048^{134}$, julgada em 2008, parece de fato modificar os rumos da jurisprudência do Supremo Tribunal Federal. No caso, decidiu-se que deve o Tribunal "exercer sua função precípua de fiscalização da constitucionalidade das leis e dos atos normativos quando houver um tema ou uma controvérsia constitucional suscitada em abstrato, independente do caráter geral ou específico, concreto ou abstrato de seu objeto". Apesar de não haver um claro abandono da caracterização da lei orçamentária como lei formal, ao menos se concluiu pela "possibilidade de submissão das normas orçamentárias ao controle abstrato de constitucionalidade", o que representa um avanço.

Essa também a conclusão de Basile Christopoulos que, após pesquisa sobre o controle de constitucionalidade no STF, entende não ser possível dizer que o STF abandonou por completo a "distinção ultrapassada entre lei formal e lei material". De qualquer modo, indica o mesmo autor que "o precedente no direito brasileiro, isto é, a

${ }^{133}$ BRASIL. Supremo Tribunal Federal. Pleno. ADI 2.925/DF. Relatora Ministra Ellen Gracie. Relator para acórdão Ministro Marco Aurélio. Julgamento 19/12/2003.

${ }^{134}$ BRASIL. Supremo Tribunal Federal. Pleno. ADI 4.048/DF. Relator Ministro Gilmar Mendes. Julgamento em 14/05/2008. 
decisão que deve orientar a produção das demais, inclusive, principalmente, as próximas decisões do Supremo Tribunal Federal, é a ADI 4.048"135.

Assim, os efeitos (concretos ou individuais) da lei passam a não ser mais determinantes para escapar ao controle de constitucionalidade. Adiciona-se que não há elementos no ordenamento jurídico nacional para que se distingua lei formal e lei material - a Constituição não faz tal distinção, tampouco o faz qualquer norma infralegal. Por esses motivos, a distinção torna-se cada vez mais histórica, sem fundamento no ordenamento jurídico atual.

De qualquer modo, mais importante do que discutir a dicotomia entre lei formal e lei material, é discutir os efeitos da lei orçamentária. Entende-se que a posição mais coerente é no sentido de que sendo o orçamento lei, formalmente e materialmente lei, pressupõe-se que sua observância é necessária para os Poderes Públicos e para os indivíduos. Daí se falar que o orçamento é impositivo, e não meramente autorizativo.

Nessa linha, o autor português Antonio Lobo Xavier afirma que sendo lei, aprovada pelo Legislativo portanto, "o orçamento vincula o Executivo, em maior ou menor medida, no sentido de que a actividade financeira há-de ficar subordinada à execução daquele

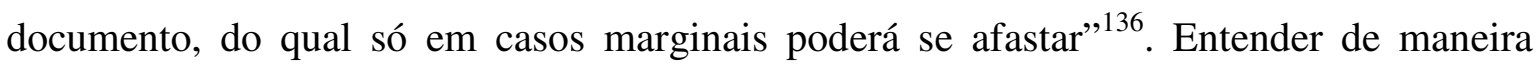
distinta, seria transformar a aprovação da lei orçamentária pelo Parlamento como mera formalidade, como defendia Laband.

Observa Tiago Duarte que "ou se aceita a parlamentarização do Orçamento, e, nesse contexto, reconhece-se uma natureza imperativa das determinações orçamentais, assim se subordinando o Governo (...), ou então torna-se ilusório pensar que a aprovação parlamentar do Orçamento cumpre uma função de determinação das premissas financeiras do Estado". O citado autor critica a opinião daqueles que consideram meramente autorizativas as verbas orçamentárias e, consequentemente, a preponderância do Executivo (“Governo") na apresentação da proposta e nas modificações durante a execução orçamentária $^{137}$.

${ }^{135}$ CHRISTOPOULOS, Basile. Controle de constitucionalidade de normas orçamentárias: o uso de argumentos consequencialistas nas decisões do Supremo Tribunal Federal. Tese de Doutorado. Faculdade de Direito da Universidade de São Paulo. São Paulo, 2014.

136 XAVIER. Antonio Lobo. Orçamento como lei: contributo para a compreensão de algumas especificidades do Direito Orçamental Português. Coimbra, 1990, p. 88. Chama atenção, ainda, a afirmação do autor que, ao menos na Europa, tal afirmação vale para qualquer dos Estados de Direito nesse contexto.

${ }^{137}$ Segundo Tiago Duarte, tratando do ordenamento jurídico português, "por detrás da proposta de aprovação da lei do Orçamento por acto legislativo do Governo econtra-se a conviç̧ão de que a aprovação parlamentar do Orçamento é, hoje em dia, um enorme tigre de papel, sendo claro que a (teórica) competência detalhada do Parlamento sobre o Orçamento, servindo para criar uma ilusão de controlo parlamentar do Governo e do Orçamento, acaba por, na realidade, se afirmar mais como um factor que acentua a desresponsabilização do 
De se mencionar, ainda, Hely Lopes Meirelles para quem "a execução do orçamento há de ser feita com fiel atendimento do que ele dispõe, quer quanto à arrecadação, quer quanto à despesa (...) executar é cumprir o determinado" ${ }^{\text {"138 }}$. E também Regis Fernandes de Oliveira, que afirma não ser a discussão sobre lei formal ou lei material exatamente o que determina a obrigação de executar o orçamento, mas as particularidades de cada caso concreto: "não se pode, objetivamente, sem considerar a realidade dos fatos, obrigar o administrador a cumprir cegamente a lei orçamentária, nem deixar a seu arbítrio eleger o que pode ou não ser efetivado"139.

Tais considerações levam ao seguinte questionamento: em que sentido há vinculação do Executivo ou obrigatoriedade no cumprimento da lei orçamentária, especialmente quanto às despesas? A questão é relevante na medida em que o orçamento traz uma previsão de receitas, cujo ingresso nos cofres públicos ocorre ao longo do exercício de execução.

A resposta mais adequada é no sentido de que devem os Governos buscar arrecadar a receita prevista e executar as despesas fixadas, aproximando-se ao máximo do que foi estabelecido na lei orçamentária. Diz-se "buscar" porque, embora lei, o cumprimento do orçamento está sujeito a diversas variáveis econômicas e políticas, as quais devem ser, e são, consideradas pelo Direito.

Quando Regis Fernandes de Oliveira menciona que há que se observar o caso concreto, bem como que não deve haver arbítrio do administrador na inexecução das despesas, isso quer dizer que há parâmetros jurídicos, hipóteses específicas para o não cumprimento das despesas previstas na lei orçamentária. Há uma flexibilidade orçamentária, mas juridicamente moldada. Essa flexibilidade advém justamente dos instrumentos de flexibilização orçamentária.

Assim, é possível que sejam feitas alterações da lei aprovada pelo Poder Legislativo ao longo da execução orçamentária, porém, estas devem seguir os parâmetros constitucionais e infraconstitucionais, especialmente os da Lei de Responsabilidade Fiscal. É importante observar que o ordenamento prevê requisitos para que sejam feitas mudanças na lei orçamentária, assim como há hipóteses e critérios para a sua não execução.

executivo, do que um factor de credibilização do Parlamento" (DUARTE, Tiago. A lei por detrás do orçamento: a questão constitucional da Lei do Orçamento. Coimbra: Almedina, 2007, pp. 632-633 e p. 645). ${ }^{138}$ MEIRELLES, Hely Lopes. Direito administrativo municipal brasileiro. São Paulo: RT, 1989.

${ }^{139}$ OLIVEIRA, Regis Fernandes de. Curso de direito financeiro. $4^{\mathrm{a}}$ ed., ver., atual e ampliada. São Paulo: Revista dos Tribunais, 2011, p. 375. 
A existência de parâmetros reforça o argumento acerca da impositividade do orçamento. A própria existência do contingenciamento, objeto desse trabalho, confirma que há impositividade na lei orçamentária. Esse argumento será aprofundado ao longo do trabalho, mas desde logo se esclarece que se há uma norma (artigo $9^{\circ}$ da Lei de Responsabilidade Fiscal) prevendo um requisito específico para que o orçamento aprovado não seja executado (cumprido), então, em regra, ele é impositivo. Considerar que o orçamento é "lei autorizativa", é dizer também que o artigo $9^{\circ}$ da Lei de Responsabilidade Fiscal não é de observância necessária. Para que prever requisitos específicos e regras para a flexibilização, se a lei não é impositiva? Não parece plausível defender que uma norma dessa natureza, vigente e eficaz no ordenamento jurídico, não seja de observância obrigatória.

Concordando com a obrigatoriedade do orçamento, pode-se citar a opinião de Adilson Abreu Dallari, que conclui, frente ao conjunto de normas do ordenamento, estar superado o antigo debate entre caráter autorizativo e impositivo do orçamento: "o sistema de orçamentos é, na verdade, um subsistema do conjunto articulado de projetos e

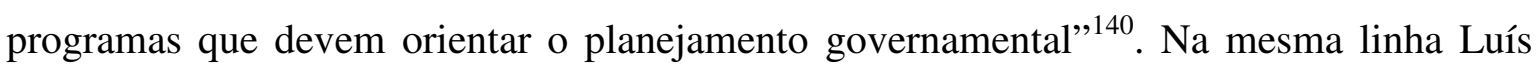
Felipe Valerim Pinheiro afirma, sobre a impositividade do orçamento, que : "não há, assim, margem de liberdade para o administrador público decidir se executa ou não a ação administrativa prevista na LOA". Não nega o autor, tal como se acabou de afirmar, que é necessário um grau de flexibilidade, mas “o ordenamento jurídico confere condições de mutabilidade aos comandos contidos na LOA para adaptá-la às circunstâncias supervenientes" ${ }^{141}$. Tal adaptação será nos limites da lei, a exemplo das condições para o contingenciamento.

A despeito dos argumentos expostos, o Executivo Federal continua encarando o orçamento brasileiro como "meramente autorizativo", o que se extrai da própria definição do termo "contingenciamento", obtida no Glossário do Ministério do Planejamento:

\section{(...) Considerando que no ordenamento jurídico brasileiro a lei orçamentária tem mantido o seu caráter autorizativo, na questão da despesa, o Poder Executivo tem se valido desse expediente para a consecução de metas de ajuste fiscal, sob o pretexto de adequar a execução da despesa ao fluxo de caixa do Tesouro. ${ }^{142}$}

\footnotetext{
${ }^{140}$ DALLARI. Adilson Abreu. Orçamento Impositivo. In CONTI, José Maurício; SCAFF, Fernando Facury (coord.). Orçamentos Públicos e Direito Financeiro. São Paulo: Editora Revista dos Tribunais, 2011, p. 327.

141 PINHEIRO. Luis Felipe Valerim. Rumo ao Orçamento Impositivo: a delimitação das ações administrativas pelas leis orçamentárias. In CONTI, José Maurício; SCAFF, Fernando Facury (coord.). Orçamentos Públicos e Direito Financeiro. São Paulo: Editora Revista dos Tribunais, 2011, p. 429.

${ }^{142}$ BRASIL. Ministério do Planejamento, Orçamento e Gestão. Glossário. Contingenciamento. Disponível em http://www.orcamentofederal.gov.br/glossario. Acesso em 24/03/2014.
} 
Não se entende, pelas razões apresentadas, que essa é a interpretação mais adequada do ordenamento jurídico. Neste passo, partindo da conclusão de que a lei orçamentária é obrigatória, a discussão sobre sua impositividade deveria ser colocada de outra forma, juridicamente mais precisa, a partir do seguinte questionamento: o que é ou não contingenciável? Essa é, inclusive, a discussão que foi retomada no Brasil com a Proposta de Emenda Constitucional que pretende "tornar impositivo" o orçamento no tocante às emendas parlamentares. O projeto, tal como aprovado no Senado Federal, traz diversas alterações ao artigo 166 da Constituição Federal. Dentre outras disposições, estabelece que "é obrigatória a execução orçamentária e financeira das programações" das emendas individuais ao projeto de lei orçamentária ${ }^{143}$. O que significa tornar uma despesa de execução obrigatória? É o mesmo que torná-la não sujeita ao contingenciamento?

Há uma indicação da resposta na disposição do $\S 17$ do artigo 166: "se for verificado que a reestimativa da receita e da despesa poderá resultar no não cumprimento da meta de resultado fiscal estabelecida na lei de diretrizes orçamentárias, o montante previsto no $\S 11$ deste artigo poderá ser reduzido em até a mesma proporção da limitação incidente sobre o conjunto das despesas discricionárias".

Do que se extrai da leitura do dispositivo, é possível o contingenciamento, desde que justificado e desde que siga a proporção das limitações das demais despesas discricionárias. Dito de outro modo, as emendas parlamentares não podem ser mais sacrificadas pelo contingenciamento do que as demais despesas do Executivo.

Algumas dificuldades acerca dessa aplicação serão aprofundadas adiante: pelos dados dos últimos anos, será difícil encontrar uma proporção na limitação das despesas discricionárias, ao menos internamente ao Poder Executivo. Isto porque, alguns grupos de despesas são, usualmente, extremamente sacrificados pelo contingenciamento, enquanto outros são pouco afetados.

\footnotetext{
${ }^{143}$ Redação, para o segundo turno, da Proposta de Emenda à Constituição nº 22A, de 2000 (nº 565, de 2006, na Câmara dos Deputados). Alteração do artigo 166 da Constituição Federal:

"§ $9^{\circ}$ As emendas individuais ao projeto de lei orçamentária serão aprovadas no limite de um inteiro e dois décimos por cento da receita corrente líquida prevista no projeto encaminhado pelo Poder Executivo, sendo que a metade deste percentual será destinada a ações e serviços públicos de saúde.

$\S 11$. É obrigatória a execução orçamentária e financeira das programações a que se refere o $\S 9^{\circ}$ deste artigo, em montante correspondente a um inteiro e dois décimos por cento da receita corrente líquida realizada no exercício anterior, conforme os critérios para a execução equitativa da programação definidos na lei complementar prevista no $\S 9^{\circ}$ do art. 165."

(Disponível em http://legis.senado.leg.br/mateweb/arquivos/mate-pdf/140049.pdf. Acesso em 25/11/2013).
} 
Em resumo, ao que parece o projeto em questão visa fazer com que a aplicação do contingenciamento se aproxime do que prevê a própria Lei de Responsabilidade Fiscal: limita-se a execução quando efetivamente há risco de não cumprimento das metas fiscais pela não arrecadação da receita prevista; quando não há risco, executa-se obrigatoriamente a despesa. A inovação do projeto é, então, inserir na Constituição o contingenciamento, mas apenas no tocante às emendas parlamentares ${ }^{144}$.

Analisando as disposições da proposta, a Consultoria de Orçamento e Fiscalização Financeira da Câmara dos Deputados bem conclui que "a grande inovação do 'orçamento impositivo' é que o contingenciamento das programações decorrentes de emenda individual deve ser proporcional ao contingenciamento aplicável às demais despesas discricionárias do Governo Federal" ${ }^{\prime 45}$. Ou seja, nada mais se faz do que reforçar uma exigência que já está na Lei de Responsabilidade Fiscal.

Enquanto não aprovada e sancionada a proposta de emenda constitucional, previsão muito semelhante foi trazida na Lei de Diretrizes Orçamentário de $2014^{146}$.

Essas disposições seriam desnecessárias se cumpridos os preceitos jurídicos da lei orçamentária, que já deveria ser entendida como impositiva, e também da Lei de Responsabilidade Fiscal, que prevê requisitos e medidas para a inexecução do orçamento aprovado.

A proposta de alteração constitucional só deixa claro que o descumprimento das regras sobre execução orçamentária está institucionalizado pela prática política. Encontrase o Direito Financeiro, nesse caso, sem força perante as práticas políticas e econômicas, tanto assim que se busca uma alteração normativa para retirar dessa prática um grupo específico de despesa: "salve-se o que puder". Tal inovação pode, entretanto, ter o efeito

\footnotetext{
${ }^{144}$ Para o governo federal, a alteração que torna o orçamento impositivo seria inconstitucional, por violar a separação de poderes: o Executivo é responsável pela execução e pela gestão das metas fiscais, não sendo essa interferência do Legislativo. Não se concorda com tal afirmação: além da concepção adotada de que o orçamento já é impositivo, entende-se ser da competência do Legislativo fiscalizar e interferir na execução orçamentária, desde que nos limites da própria lei orçamentária aprovada. Sobre esse ponto, vide JUNQUEIRA, Caio. Governo prepara ação no STF contra orçamento impositivo. Valor Econômico. Disponível em http://www.valor.com.br/brasil/3166018/governo-prepara-acao-no-stf-contra-orcamentoimpositivo. Acesso em 25/03/2014. Vide, também, LUGULO, Marise. Adoção do orçamento impositivo não é inconstitucional, afirma juiz. Portal da Câmara dos Deputados. Disponível em http://www2.camara.leg.br/camaranoticias/noticias/ADMINISTRACAO-PUBLICA/444230-ADOCAO-DOORCAMENTO-IMPOSITIVO-NAO-E-INCONSTITUCIONAL,-AFIRMA-JUIZ.html. Acesso em 25/03/2014.

${ }^{145}$ BRASIL. Câmara dos Deputados. Consultoria de Orçamento e Fiscalização Financeira. Estudo Técnico no 01/2014: Possível conflito entre as "travas" e limites da LRF e o orçamento impositivo. Disponível em http://www2.camara.leg.br/atividade-

legislativa/orcamentobrasil/estudos/2014/ET012014OramentoImpositivo.pdf. Acesso em 04/06/2014.

${ }^{146}$ Conforme artigo 52 da Lei no $12.919 / 2013$.
} 
maléfico de legitimar a prática de contingenciamento já existente ou, ainda, criar suborçamentos, cada um com um grau de execução distinto.

\subsection{O Contingenciamento e seus requisitos: $\operatorname{artigo} 9^{\circ}$ da Lei de Responsabilidade Fiscal}

2.3.1. O risco de não realização das receitas: o caput do artigo $9^{\circ}$ da Lei de Responsabilidade Fiscal

O contexto em que está inserido o contingenciamento tem por principais premissas: o fato de a lei orçamentária anual dispor sobre a previsão de receitas (e não as receitas arrecadadas), a necessidade de ajustar o fluxo das despesas conforme a arrecadação dessas receitas ao longo do exercício e a necessidade de cumprimento de metas físcais.

Assim, considerando que tais premissas estão sujeitas a variações ao longo do exercício, já que influenciadas por fatores econômicos e políticos, a Lei de Responsabilidade Fiscal trouxe a possibilidade de que o Poder Público procedesse à limitação de empenho e de movimentação financeira (contingenciamento), caso "a realização de receitas não comportar o cumprimento das metas fiscais de resultado primário ou nominal estabelecidas no Anexo de Metas Fiscais". Vale aqui transcrever o teor do artigo $9^{\circ}$ da Lei de Responsabilidade Fiscal:

Art. $9^{\circ}$. Se verificado, ao final de um bimestre, que a realização da receita poderá não comportar o cumprimento das metas de resultado primário ou nominal estabelecidas no Anexo de Metas Fiscais, os Poderes e o Ministério Público promoverão, por ato próprio e nos montantes necessários, nos trinta dias subsequentes, limitação de empenho e movimentação financeira, segundo os critérios fixados pela lei de diretrizes orçamentárias.

Pela leitura da norma, obviamente considerando o contexto em que se insere, extrai-se que a limitação de empenho e movimentação financeira (contingenciamento) apenas será feita caso implementada a condição prevista em lei, qual seja, de que realização da receita poderá não comportar o cumprimento das metas físcais. Nota-se, inclusive, que a redação do artigo começa com a utilização da conjunção condicionante “se”, a qual exprime, por óbvio, condição, hipótese ${ }^{147}$. Insiste-se nesse ponto para deixar claro que o ato de limitação de empenho e de movimentação financeira (ato de

147 Michaelis - Moderno Dicionário da Língua Portuguesa. Disponível em http://michaelis.uol.com.br/. Acesso em 23/05/2014. 
contingenciamento) só é praticado na hipótese de (sob a condição de) ser verificado que a realização de receita pode não comportar o cumprimento das metas fiscais.

Colocando uma lupa sobre a condição do contingenciamento, é possível observar que as metas fiscais são fixadas pela Lei de Diretrizes Orçamentárias (mais especificamente no Anexo de Metas Fiscais) para o exercício seguinte. Por essa razão, essa meta certamente deve influenciar a elaboração da Lei Orçamentária Anual, especialmente quanto à fixação das despesas. É dizer, a despesa deve ser fixada em um montante tal que possa ser suportado pelas receitas a serem arrecadadas, considerando também a meta fiscal a ser alcançada (basicamente o superavit primário, cuja repercussão será aprofundada no capítulo seguinte).

Todos esses elementos devem conversar entre si, ao menos no início do exercício. Entretanto, como a receita é uma previsão que depende de variáveis econômico-políticas, sua não realização pode provocar um desajuste entre esses elementos: ou não será alcançada a meta fiscal de superavit primário ou não se executará a despesa. A Lei de Responsabilidade Fiscal determina que seja limitada a execução da despesa, a despeito de, na prática, também possa ocorrar, por vezes, uma reavaliação do superavit primário.

Em outras palavras, o que se tem como fundamento do contingenciamento, portanto, é a não realização das receitas previstas ou, ao menos, um risco de não realização dessas receitas. Fala-se em risco, já que a redação é "poderá não comportar" as metas.

Assim, a utilização do contingenciamento não está sujeita à mera discricionariedade do administrador público. A norma traz explicitamente um requisito para a limitação de empenho e movimentação financeira, razão pela qual não é medida a ser tomada em qualquer circunstância, mas tão somente se verificado o mencionado requisito. Essa é a interpretação de grande parte da doutrina.

Para Regis Fernandes de Oliveira, é defeituosa e não factível a interpretação que afirma haver a possibilidade permanente do contingenciamento, em quaisquer circunstâncias. Afirma o autor: "é obrigatória, em verdade, uma vez que ocorridos os pressupostos de sua emanação, deve advir o ato de restrição à despesa" ${ }^{\text {"148. Desse }}$ raciocínio, extrai-se a conclusão de que "não se pode efetuar o contingenciamento a qualquer hora e indistintamente, sem razões hábeis e fundamentação adequada". Tal atitude por parte dos governantes "foge aos bons princípios da gestão pública" 149 .

\footnotetext{
${ }^{148}$ OLIVEIRA, Regis Fernandes de. Curso de direito financeiro. $4^{a}$ ed., ver., atual e ampliada. São Paulo: Revista dos Tribunais, 2011, p. 324.

${ }^{149}$ Ibidem, p. 325
} 
No mesmo sentido, Gabriel Lochagin aponta que não se justifica a decisão imotivada de o Executivo "deixar de cumprir os objetivos orçamentários sem que se tenha evidenciado algum risco à instabilidade econômica"150.

Ainda, Élida Graziane Pinto, discorrendo sobre o artigo $9^{\circ}$ da Lei de Responsabilidade Fiscal, aponta que há "pressupostos de direito que devem ser explicitados diante do quadro concreto, para que a inexecução de políticas públicas previstas no orçamento não decorra apenas da ineficiência alocativa do Estado, ou de omissão deliberada do gestor público no cumprimento de seus deveres constitucionais"151.

Cita-se, também, Maurício Barros, para quem "o ato de contingenciar uma determinada despesa prevista na LOA não se encontra, a priori, dentro da esfera de liberdade do administrador, eis que a possibilidade ou não de efetuar o gasto será pautada pelo caso concreto e pela finalidade". No caso do contingenciamento, as situações deveriam ser afigurar como absolutamente excepcionais, como classifica o mesmo autor ${ }^{152}$.

Para finalizar a análise do caput do artigo $9^{\circ}$, há ainda um último ponto. A redação estabelece que a limitação de empenho e de movimentação financeira será feita "por ato próprio e nos montantes necessários (...) segundo os critérios fixados pela lei de diretrizes orçamentárias".

$\mathrm{O}$ ato próprio, no âmbito federal, foco da análise, é feita a partir de decreto do Executivo. Trata-se, usualmente, de decreto que dispõe também sobre a programação orçamentária e financeira e estabelece o cronograma mensal de desembolso. É, portanto, um decreto de execução orçamentária, no qual estão incluídos os limites de empenho e movimentação financeira (contingenciamento). Nos últimos anos, essas informações têm sido trazidas no Anexo I dos decretos.

Quanto aos critérios fixados pela lei de diretrizes orçamentárias, já se mencionou o artigo $4^{\text {o }}$, I, 'b', da Lei de Responsabilidade Fiscal. A norma determina que a LDO disponha sobre os critérios e a forma de limitação de empenho. Tomando como exemplo a Lei de Diretrizes Orçamentárias para 2014 (Lei n 12.919/2013), verificam-se em seu artigo 51 diversas disposições a serem seguidas caso necessária a limitação de empenho. Cita-se que o Poder Executivo apurará o montante necessário e informará cada órgão

${ }^{150}$ LOCHAGIN, Gabriel Loretto. A flexibilidade da execução orçamentária. Dissertação de Mestrado em Direito. Faculdade de Direito da Universidade de São Paulo. São Paulo, 2012.

151 PINTO, Élida Graziane. Financiamento de Direitos Fundamentais: políticas públicas vinculadas, estabilização monetária e conflito distributivo no orçamento da União do pós-Plano Real. Belo Horizonte: Editora O Lutador, 2010, p. 135.

${ }^{152}$ BARROS, Maurício. Orçamento e Discricionariedade. In CONTI, José Maurício; SCAFF, Fernando Facury (coord.). Orçamentos Públicos e Direito Financeiro. São Paulo: Editora Revista dos Tribunais, 2011, p. 1003. 
orçamentário dos demais Poderes ${ }^{153}$ (caput do artigo 51); que a limitação pelos Poderes será estabelecido de forma proporcional à participação de cada um no conjunto das dotações orçamentárias iniciais classificadas como despesas primárias discricionárias $\left(\S^{\circ}\right.$ do artigo 51); algumas despesas que não serão afetadas pela limitação ( $\$ 1^{\circ}$ do artigo 51) e a necessidade de o Poder Executivo divulgar na internet e encaminhar ao Congresso Nacional cálculos e considerações sobre a execução orçamentária ( $4^{\circ}$ do artigo 51).

Dado um panorama geral sobre os elementos do caput do artigo $9^{\circ}$ da Lei de Responsabilidade Fiscal, passa-se a enquadrar o contingenciamento dentro de uma determinada figura jurídica, de modo a melhor visualizar possíveis ilegalidades na sua prática.

2.3.2. O contingenciamento sob a perspectiva do ato administrativo: motivo, motivação e finalidade do ato

Seguindo na análise do caput, adota-se uma perspectiva que pressupõe o ato de contingenciamento como um ato administrativo e cujos elementos devem, por certo, respeitar as condições legais.

$\mathrm{O}$ ato de contingenciamento pode ser qualificado como ato administrativo, pois: (i) constitui uma declaração do Estado, mais especificamente, uma declaração do Executivo; (ii) está sujeito ao regime jurídico administrativo (não é ato da Administração Pública sujeita ao direito privado); (iii) produz efeitos jurídicos imediatos sobre a execução do orçamento, pela limitação de empenho e de movimentação financeira; (iv) está sujeito à lei, mais especificamente aos requisitos da Lei de Responsabilidade Fiscal (mas também às leis orçamentárias); (v) tendo requisitos legais, está sujeito ao controle judicial ${ }^{154}$. Em suma, o contingenciamento pode ser configurado como uma declaração de vontade do Poder Executivo, manifestada por decreto, que visa dar cumprimento às leis orçamentárias

\footnotetext{
${ }^{153}$ A relação do contingenciamento com os demais Poderes será tratada item próprio, a partir das disposições do $\S 3^{\circ}$ do artigo $9^{\circ}$ da Lei de Responsabilidade Fiscal.

${ }^{154}$ São inúmeros os autores que definem ato administrativo. Mencionaram-se os requisitos apontados em DI PIETRO. Maria Sylvia Zanell. Direito Administrativo. 23a ed. São Paulo: Atlas, 2010, p. 195. Definição semelhante é a de Celso Antônio Bandeira de Mello: "a declaração do Estado (...), no exercício de prerrogativas públicas, manifestada mediante providências jurídicas complementares da lei a título de lhe dar cumprimento, e sujeita a controle de legitimidade por órgão jurisdicional" (BANDEIRA DE MELLO, Celso Antônio. Curso de Direito Administrativo. 20ª edição. São Paulo: Malheiros, 2006, p. 358).
} 
e à Lei de Responsabilidade Fiscal, cujos efeitos envolvem a limitação de empenho e de movimentação financeira ${ }^{155}$.

Assim como sua definição, os elementos e requisitos/pressupostos do ato administrativo são tratados das mais diversas formas pela doutrina: o que para alguns autores são os elementos, para outros são os requisitos ou pressupostos.

Celso Antônio Bandeira de Mello, por exemplo, entende que são elementos do ato administrativo apenas o que é intrínseco a ele, portanto, o conteúdo e a forma, sendo o objeto e a pertinência, os pressupostos de existência; e o sujeito, o motivo, a finalidade, a causa e a formalização, os pressupostos de validade. De modo distinto, Diógenes Gasparini analisa o ato administrativo a partir de seus requisitos, os quais entende ser: agente competente, finalidade, forma, motivo, conteúdo, objeto e causa ${ }^{156}$. Já Maria Sylvia Zanella Di Pietro elabora seu estudo com base nos elementos do ato administrativo, sendo eles: sujeito, objeto, forma, finalidade e motivo ${ }^{157}$.

Poder-se-ia apontar inúmeras nomenclaturas dadas pelos diversos doutrinadores de Direito Administrativo. Entretanto, como diz Celso Antônio Bandeira de Mello, não há grande relevância na discussão sobre os nomes, se causas, requisitos ou pressupostos, mas importa adotar um modelo para análise das condições de validade e de produção do ato $\operatorname{administrativo~}^{158}$.

São justamente as condições/elementos/requisitos de validade que importam para verificar se o ato administrativo atende a seus requisitos legais, inclusive para que seja possível exercer controle sobre ele. Não se preocupará, por ora, com o sujeito (considerando o contingenciamento a partir do Executivo ${ }^{159}$ ). Quanto à formalização do ato (através de decreto), não se vislumbram maiores discussões. Tampouco quanto ao conteúdo ou objeto (impedir a execução de determinadas despesas), exceto nos casos de contingenciamento de despesas não contingenciáveis (por previsão da LDO, por exemplo, abordadas em item próprio). A maior preocupação nesse momento está focada na análise do motivo e da finalidade do ato. Esses os principais focos de problema perante a disposição do artigo $9^{\circ}$ da Lei de Responsabilidade Fiscal.

\footnotetext{
155 Ainda que se discorde dessa definição, é igualmente possível chegar, por outros caminhos, na conclusão da ilegalidade de algumas práticas relativas ao contingenciamento. Utiliza-se do referencial teórico do ato administrativo para auxiliar o raciocínio.

${ }^{156}$ GASPARINI, Diogenes. Direito Administrativo. 12a edição. São Paulo: Saraiva, 2007, p. 62

${ }_{157}^{15}$ DI PIETRO. Maria Sylvia Zanella. Direito Administrativo. $18^{a}$ edição. São Paulo: Atlas, 2005, p. 195.

158 BANDEIRA DE MELlO, Celso Antônio. Curso de Direito Administrativo. 20 a edição. São Paulo: Malheiros, 2006, p. 365, nota de rodapé 21.

${ }^{159}$ Há discussões sobre os efeitos do contingenciamento "determinado" pelo Executivo sobre os demais Poderes, tema será abordado em item próprio.
} 
Quanto ao motivo, Celso Antônio Bandeira de Mello o descreve como o "pressuposto de fato que autoriza ou exige a prática do ato", devendo haver, se não previsão legal, ao menos suportes fáticos idôneos que comportem a prática do ato específico $^{160}$. Em sentido semelhante, Maria Sylvia Zanella Di Pietro define motivo como pressuposto de direito (dispositivo legal) e o pressuposto de fato (conjunto de circunstâncias e acontecimentos que levam à prática do ato) ${ }^{161}$.

Transpondo às definições para o caso do contingenciamento, tem-se que o motivo legal ou pressuposto de direito é a Lei de Responsabilidade Fiscal (artigo $9^{\circ}$ ) e o motivo fático ou pressuposto fático é a possibilidade de que a (não) realização da receita não comporte o cumprimento das metas fiscais. Pode-se falar em risco de descumprimento das metas fiscais por não realização da receita prevista.

Em um primeiro momento, aparenta o contingenciamento se tratar de ato vinculado, ou seja, diante de uma situação de fato, a lei estabelece uma única solução: verificado o risco de não cumprimento das metas pela não realização de receitas, é necessário o contingenciamento. No entanto, conforme expõe novamente Maria Sylvia Zanella Di Pietro, o motivo pode ser considerado discricionário quando a lei define noções vagas ou utiliza conceitos jurídicos indeterminados, "que deixam à Administração a possibilidade de apreciação segundo critérios de oportunidade e conveniência"162.

Veja-se que o motivo para o contingenciamento não é de identificação precisa, já que envolve uma avaliação de risco (variáveis, cálculos e previsões). Adotando a corrente que entende haver discricionariedade nesses casos, pode-se afirmar que o contingenciamento é ato discricionário, ao menos na avaliação desse risco. Acrescenta-se, ainda, a existência de flexibilidade na alteração de previsões orçamentárias (ainda que sujeita a regras específicas), o que permite em alguma medida juízos de conveniência e oportunidade, a despeito dos limites nas metas impostas pela Lei de Diretrizes Orçamentárias.

De qualquer modo, entendendo-se o ato como vinculado ou como discricionário na avaliação quanto ao motivo, é inescapável a conclusão de que se o ato é praticado, o motivo deve estar configurado. Ao invés de se alongar no debate entre ato vinculado e

160 BANDEIRA DE MELLO, Celso Antônio. Curso de Direito Administrativo. 20 a edição. São Paulo: Malheiros, 2006. O autor distingue, ainda, o motivo do ato e o motivo legal, sendo este a situação fática material e empírica e aquele a previsão abstrata da situação.

${ }_{161}^{161}$ DI PIETRO. Marya Sylvia Zanella. Direito Administrativo. $18^{\mathrm{a}}$ edição. São Paulo: Atlas, 2005, p. 210.

${ }^{162}$ Segundo a autora, trata-se de entendimento de corrente majoritária, mas há uma corrente que entende que conceitos indeterminados não conferem discricionariedade à Administração, já que deve ela fazer uma interpretação do conceito que leva a uma única solução válida possível (DI PIETRO. Marya Sylvia Zanella. Direito Administrativo. 18 edição. São Paulo: Atlas, 2005, p. 215). 
discricionário, importa concluir que é preciso a existência do motivo, a observância do pressuposto fático para o ato.

Ademais, não só deve estar presente o motivo, mas deve ele estar demonstrado, já que a motivação (exposição dos motivos) é também elemento do ato administrativo, essencial, inclusive, para seu controle. A motivação tem função, segundo Antônio Carlos Araújo Cintra, de forçar um cuidado maior do agente público no exame de questões de legalidade e de conveniência e oportunidade, reduz a prática de arbitrariedades, facilita o controle e serve como elemento empregado na interpretação do real alcance dos atos administrativos ${ }^{163}$. É nesse sentido a teoria dos motivos determinantes, segundo a qual "a validade do ato se vincula aos motivos indicados como seu fundamento, de tal modo que, se inexistentes ou falsos, implicam a sua nulidade"164.

Em suma, será ilegal o contingenciamento se inexistentes ou equivocados os motivos ou, ainda, se não puderem ser aferidos, controlados (ausência de motivação). As críticas quanto à prática do contingenciamento serão apresentadas nos capítulos seguintes. Apenas para ilustrar o raciocínio desenvolvido, pode-se mencionar, por exemplo, que os “contingenciamentos preventivos", feitos logo no início do ano, em período no qual não é possível (ou pouco provável) que se verifique riscos de não realização de receitas que afetem as metas fiscais, contêm deficiência nos motivos. Como se verá, é ampla a doutrina que crítica o motivo e a motivação do contingenciamento.

Como se disse anteriormente, os problemas referentes ao contingenciamento não se limitam apenas ao motivo e motivação do ato, mas alcançam também sua finalidade.

Segundo Maria Sylvia Zanella Di Pietro, a finalidade é o resultado que a Administração quer alcançar com a prática do ato, podendo esta ser, em sentido amplo, o interesse público e, em sentido estrito, resultado específico conforme definido em lei ${ }^{165}$. No caso do contingenciamento, além do necessário atendimento ao interesse público, a finalidade específica é o bloqueio de parte da execução orçamentária com vistas ao cumprimento das metas fiscais. Neste passo, o contingenciamento que serve a outra finalidade que não a prevista em lei, será ilegal, em razão do que se denomina em Direito Administrativo de desvio de finalidade ou desvio de poder.

Nos capítulos seguintes serão mencionados casos acerca da utilização do contingenciamento com o intuito de controle de poder no Legislativo, o que se demonstra

163 CINTRA, Antônio Carlos de Araújo. Motivo e Motivação do Ato Administrativo. São Paulo: Editora Revista dos Tribunais, 1979, p. 113

${ }^{164}$ DI PIETRO. Marya Sylvia Zanella. Direito Administrativo. $18^{\text {a }}$ edição. São Paulo: Atlas, 2005, p. 210.

${ }^{165}$ Ibidem, p. 209. 
principalmente a partir do "descontingenciamento", da liberação dos recursos. Uma vez que não existem critérios transparentes relativos à liberação de recursos, bem como que não se cumpre retomada proporcional da execução, há sérias suspeitas de que haja recorrentes desvios de finalidade na aplicação do contingenciamento. Certamente que o uso do contingenciamento como mecanismo de controle do Legislativo pelo Executivo não atende o interesse público, inclusive por violar o planejamento do gasto público (legalmente fixado), a transparência e a moralidade administrativa.

Cumpre ainda observar que os problemas relativos ao motivo, moticação e finalidade do contingenciamento podem igualmente se traduzir em inconstitucionalidades, se confrontadas com as disposições do artigo 37 da Constituição Federal, em especial em face dos princípios da legalidade (decorrente da própria violação dos requisitos artigo $9^{\circ}$ da Lei de Responsabilidade Fiscal), da impessoalidade (utilização do contingenciamento com finalidades exclusivamente políticas) e da moralidade e publicidade (ausência de motivo e motivação na prática do ato).

Ademais, pode também haver violação da Constituição Federal se os decretos de contingenciamento impedem que o orçamento mínimo das áreas da educação e da saúde, por exemplo, seja executado. Ou seja, se a aplicação do contingenciamento impede que se realizem os gastos mínimos com saúde e educação, haverá violação, respectivamente, dos artigos 198 e 212 da Constituição Federal ${ }^{166}$.

Finaliza-se esse tópico esclarecendo que, sem o intuito de analisar cada um dos decretos de contingenciamento, pretendeu-se desenvolver um raciocínio jurídico que permita o controle de legalidade (e, por decorrência, de constitucionalidade) da aplicação desse instrumento, especialmente por meio da apreciação do motivo, da motivação e da finalidade do ato. A análise dos dados e das críticas doutrinárias demonstrará que existem problemas na aplicação do contingenciamento, os quais se traduzem juridicamente por vícios no motivo, na motivação e na finalidade, os quais devem ser submetidos a controle.

2.3.3. Restabelecimento de receita e retomada proporcional da execução: $\S 1^{\circ}$ do artigo $9^{\circ}$ da Lei de Responsabilidade Fiscal

\footnotetext{
${ }^{166}$ É bem verdade que essa hipótese não ocorrerá caso observado o $\S 2^{\circ}$ do artigo $9^{\circ}$,que estabelece que "não serão objeto de limitação as despesas que constituam obrigações constitucionais e legais do ente". Maiores apontamentos sobre o tema serão feitos no item relativo aos efeitos do contingenciamento sobre a realização de políticas públicas.
} 
Conforme exposto, a aplicação do contingenciamento tem como pressuposto fático o risco de não realização de receitas que ameace o cumprimento das metas fiscais. Como se observa, decorre de evento(s) verificado(s) ao longo da execução orçamentária e que contraria as previsões feitas quando da elaboração da lei orçamentária anual.

Ocorre que, ainda dentro da execução orçamentária, é possível que tal risco desapareça e haja uma retomada da realização da receita prevista, ainda que parcialmente. Nesse caso, determina o $\S 1^{\circ}$ do artigo $9^{\circ}$ da Lei de Responsabilidade Fiscal que deve haver a recomposição dos empenhos limitados pelo decreto de contingenciamento. Ou seja, deve-se prosseguir a execução orçamentária prevista originalmente na lei para aquele exercício. E não só, essa retomada da execução deve ser proporcional às reduções que haviam sido efetivadas. Veja-se o teor da norma:

$\S 1^{\circ}$ No caso de restabelecimento da receita prevista, ainda que parcial, a recomposição das dotações cujos empenhos foram limitados dar-se-á de forma proporcional às reduções efetivadas.

A determinação do $\S 1^{\circ}$ do artigo $9^{\circ}$ confirma que o contingenciamento deve se comportar como uma norma de excepcionalidade. Em eventos não levados em conta na elaboração da Lei Orçamentária Anual, deve atuar a limitação de empenho e movimentação financeira. Passados esses eventos, restabelece-se a receita prevista, retomase a "normalidade", prossegue-se na execução inicialmente prevista, recompondo as dotações de forma proporcional.

Sobre a referida norma cabem algumas observações. Em primeiro lugar, a determinação reforça a necessidade de que o contingenciamento de recursos seja motivado e, mais, que a manutenção, ampliação ou redução do contingenciamento também o seja. Isto porque, deve ser possível aferir se a não realização de receitas está ocorrendo para que se retome ou, por outro lado, amplie-se o contingenciamento.

Em segundo lugar, para a "liberação" dos recursos contingenciados ou recomposição das dotações, não há total liberdade do gestor público, já que essa deve se dar "de forma proporcional às reduções efetivadas". Assim, os órgãos mais atingidos pela limitação de empenho e movimentação financeira devem ser os mais contemplados pela retomada da execução. Do contrário, não se tem proporcionalidade. Se a lei não previu expressamente que o contingenciamento de recursos deve atingir igualmente cada órgão, de outra parte, previu que o descontingenciamento deve ser proporcional à redução efetivada. Entende-se que a proporcionalidade deve respeitar tanto a relação entre os 
Poderes (Executivo, Legislativo e Judiciário), quanto a relação dentro de cada Poder (entre os Ministérios do Executivo, por exemplo).

É importante ressaltar que a determinação do $\S^{\circ}$ do $\operatorname{artigo} 9^{\circ}$ da Lei de Responsabilidade Fiscal é plenamente justificável do ponto de vista da legalidade e da legitimidade democrática da lei orçamentária. O orçamento é lei, aprovada portanto pelo Legislativo, elemento que que lhe confere tal legitimidade e permite controle. Se por meio do contingenciamento (veiculado via decreto, ou seja, ato unilateral do Executivo), há plena liberdade na recomposição das dotações, há grave risco de descaracterização do orçamento aprovado. Por isso é adequada a limitação da discricionariedade do gestor público trazida pela norma.

A despeito de não haver, portanto, plena liberdade ao administrador público para escolha das dotações a serem retomadas, por outro lado, deve-se aceitar uma margem de "desproporcionalidade", ou melhor, não se deve considerar uma proporcionalidade "estrita", a fim de se adequar a execução aos tipos de despesas e às situações fáticas específicas. Explica-se a partir de um exemplo hipotético.

Imagina-se que o contingenciamento efetivado foi de \$ 100 para o Executivo e foram limitados \$50 do Ministério da Defesa e \$50 do Ministério da Ciência e Tecnologia. Houve, ao longo do mesmo exercício, a retomada da realização de receitas, porém, apenas de forma parcial. Será possível, conforme previsões e cálculos do governo, uma retomada das dotações de apenas $\$ 50$, ou seja, metade do contingenciado inicialmente. Como a retomada deve ser proporcional, nos termos do $\S 1^{\circ}$ do artigo $9^{\circ}$, deveria ser recomposto \$ 25 da dotação do Ministério da Defesa e \$ 25 para o Ministério da Ciência e Tecnologia.

Ocorre que retomar as dotações dessa forma (atendendo a uma proporcionalidade rígida) pode ser inadequado no caso concreto. Por exemplo, se o Ministério da Ciência e Tecnologia utilizará a recomposição para a compra de computadores, a depender do valor retomado comprará mais ou menos computadores. De outra parte, o Ministério da Defesa precisa finalizar a construção de uma obra, o que só seria feito se for liberado \$30 (\$25 não permitiria finalizar a obra). Assim, considerando a complexidade orçamentária e abandonando uma proporcionalidade rígida, seria mais adequado liberar $\$ 30$ para o Ministério da Defesa concluir a obra e \$ 20 para o Ministério da Ciência e Tecnologia comprar computadorees até esse montante. O governo deixará de comprar $\$ 5$ em computadores, mas finalizará uma obra (que incompleta não teria sentido). 
Portanto, a complexidade da execução deve permitir uma margem na recomposição das dotações que não leve em conta uma proporcionalidade rígida. Isso não significa que não deve haver nenhuma proporcionalidade. Assim, no exemplo dado, se os $\$ 50$ da recomposição forem direcionados unicamente para o Ministério da Defesa, e \$ 0 para o Ministério da Ciência e Tecnologia, haverá, nessa hipótese, forte indício de que a proporcionalidade do artigo $9^{\circ}, \S 1^{\circ}$ da Lei de Responsabilidade Fiscal não foi observada.

Desta forma, é fundamental que o gestor público esclareça os critérios acerca das limitações que estão sendo feitas para que, quando retomada a execução, seja possível verificar as proporções necessárias. Algumas outras notas sobre a desproporcionalidade na retomada da execução e sua utilização como mecanismo de controle político serão trazidas a partir da análise dos dados ${ }^{167}$.

2.3.4. A proteção das obrigações legais e constitucionais: $\S 2^{\circ}$ do $\operatorname{artigo} 9^{\circ}$ da Lei de Responsabilidade Fiscal

O artigo $9^{\circ}$ da Lei de Responsabilidade Fiscal faz, em seu $\S 2^{\circ}$, elenca as despesas que não podem ser contingenciadas. Dispõe que não serão objeto de limitação (i) as obrigações constitucionais e legais do ente, inclusive o pagamento do serviço da dívida e (ii) as despesas ressalvadas pela lei de diretrizes orçamentárias. Veja-se o teor da norma:

$\S 2^{\circ}$. Não serão objeto de limitação as despesas que constituam obrigações constitucionais e legais do ente, inclusive aquelas destinadas ao pagamento do serviço da dívida, e as ressalvadas pela lei de diretrizes orçamentárias.

A norma veiculada pelo $\S 2^{\circ}$ do artigo $9^{\circ}$ impede que o contingenciamento recaia, portanto, sobre dois tipos de despesas: as denominadas "obrigatórias" e as ressalvadas pela Lei de Diretrizes Orçamentárias.

Quanto às despesas obrigatórias (ou decorrentes de obrigações legais e constitucionais), trata-se daquelas para as quais há uma obrigação prevista em lei ou na Constituição antes mesmo da lei orçamentária ${ }^{168}$. Trata-se de despesas cuja execução é

\footnotetext{
${ }^{167}$ Conforme aprofundado adiante, a retomada da execução a partir de descontingenciamentos apenas tem observado uma proporcionalidade entre os Poderes (em referência ao orçamento aprovado), mas não internamente aos Poderes. Não é possível verificar proporcionalidade entre os órgãos do Executivo.

${ }^{168}$ Conforme CARVALHO, André Castro. Vinculação de Receitas Públicas. São Paulo: Quartier Latin, 2010, p. 118. O autor diferencia as despesas obrigatórias, cuja execução é mandatória no exercício, das vinculações de receitas. Para estas, não há uma obrigatoriedade de gasto anual dos recursos, mas estabelecese um elo entre receita e uma finalidade, de forma que se esses recursos forem aplicados, seja naquele ano,
} 
obrigatória naquele exercício e, justamente por isso, não podem ser objeto de contingenciamento.

Regis Fernandes de Oliveira menciona como obrigações constitucionais os gastos mínimos obrigatórios com educação (artigo 212) e saúde ( $\S 2^{\circ}$ e $\S 3^{\circ}$ do artigo 198); e como obrigações legais as despesas com servidores públicos (decorrente da lei dos servidores públicos) e o serviço da dívida (classificado como obrigatório pelo próprio artigo $9^{\circ}$ da Lei de Responsabilidade Fiscal). Pode-se dizer que, se a restrição não pode alcançar esses gastos obrigatórios, somente pode recair sobre despesas discricionárias ${ }^{169}$.

Aliás, a própria definição de contingenciamento dada pela Secretaria de Orçamento Federal (vinculada ao Ministério do Planejamento) reafirma que só há possibilidade de contingenciar despesas discricionárias ou não legalmente obrigatórias:

O contingenciamento consiste no retardamento ou, ainda, na inexecução de parte da programação de despesa prevista na Lei Orçamentária em função da insuficiência de receitas. Normalmente, no início de cada ano, o Governo Federal emite um Decreto limitando os valores autorizados na LOA, relativos às despesas discricionárias ou não legalmente obrigatórias (investimentos e custeio em geral). ${ }^{170}$

É por isso que, conforme esclarece Vander Gontijo, a discussão sobre a impositividade do orçamento recai apenas sobre as despesas discricionárias, cuja maioria é constituída por outras despesas correntes e investimentos. Os gastos com pessoal ativo e inativo e demais obrigações legais e constitucionais são despesas obrigatórias, ou seja, não são contingenciáveis ${ }^{171}$.

Seguindo o mesmo raciocínio, Onildo Rodrigues Soares, analisando o artigo $9^{\circ}, \S$ $2^{\mathrm{o}}$ da Lei de Responsabilidade Fiscal, define o contingenciamento como o "bloqueio de parte dos valores autorizados na Lei Orçamentária, relativos às despesas discricionárias ou não-legalmente obrigatórias (investimentos e custeio em geral)" ${ }^{\prime 172}$.

De se esclarecer que os autores mencionados mesclam duas formas de classificação: primeira, que opõe despesas obrigatórias e despesas discricionárias; e

seja em anos posteriores, devem ser naquela finalidade. Trata-se, inclusive, de interpretação que decorre do artigo $8^{\circ}$, parágrafo único da Lei de Responsabilidade Fiscal.

169 OLIVEIRA, Regis Fernandes de. Curso de direito financeiro. $4^{\mathrm{a}}$ ed., ver., atual e ampliada. São Paulo: Revista dos Tribunais, 2011, p. 326.

${ }^{170}$ BRASIL. Ministérios do Planejamento, Orçamento e Gestão. Secretaria do Orçamento Federal. Perguntas Frequentes. $O \quad$ que é contingenciamento?. http://www.orcamentofederal.gov.br/perguntasfrequentes/4.como-faco-para-me-cadastrar-no-curso-deorcamento-publico-da-escola-virtual-sof. Acesso em 24/03/2014.

${ }^{171}$ GONTIJO, Vander. Orçamento impositivo, contingenciamento e transparência. In: Cadernos Aslegis, n.39, p. 61-72, jan/abr 2010, p. 63.

172 SOARES, Onildo Rodrigues. Os Impactos que decretos de contingenciamento causam ao desempenho das agências reguladoras federais. Trabalho de Pós-Gradução. PPGA. Universidade de Brasília. 2009, p. 08. 
segunda, que divide as despesas em correntes e de capital. A primeira classificação é a que parece ter sido incorporada pelo artigo $9^{\circ}, \S 2^{\circ}$, da Lei de Responsabilidade Fiscal, acima tratada. A segunda classificação é a utilizada pela Lei n ${ }^{\circ}$ 4.320/64 (artigos 12 e 13), a partir de um critério econômico e conforme a consequência produzida: as despesas correntes não agregam ativos para o ente que as realiza, enquanto as despesas de capital tem essa finalidade ${ }^{173}$. É certo que grande parte das despesas correntes são também obrigatórias, pois englobam as despesas com pessoal, enquanto que as despesas de capital são em boa parte discricionárias, e englobam os investimentos. Nessa linha, justifica-se as observações dos autores citados de que o contingenciamento atinge os investimentos.

Retornando ao artigo $9^{\circ}, \S 2^{\circ}$, além das denominadas “despesas obrigatórias", também não podem ser contingenciadas as despesas protegidas pela própria Lei de Diretrizes Orçamentárias. A fim de orientar a execução do ano seguinte, a LDO pode elencar despesas discricionárias (de programas específicos) como não contingenciáveis, deixando-as fora da possibilidade de limitação de empenho e movimentação financeira. Via de regra, as despesas que não estão sujeitas à limitação de empenho durante a execução orçamentária são trazidas em um dos anexos dessa lei.

Neste Anexo consta a lista das "Despesas que não serão objeto de limitação de empenho, nos termos do artigo $9^{\circ}, \S 2^{\circ}$ da Lei de Responsabilidade Fiscal”. Usualmente, esse anexo trazia duas categorias de despesas: I) Despesas que constituem obrigações legais e constitucionais da União e II) Demais despesas ressalvadas. Trata-se justamente das duas categorias do $\S 2^{\circ}$ do artigo $9^{\circ}$.

Veja-se, como exemplo, a Lei de Diretrizes Orçamentárias para 2011 (Lei no 12.309/10). O Anexo IV da lei trouxe, além da lista de "despesas obrigatórias", as despesas discricionárias ressalvadas do contingenciamento, que incluíam despesas relativas à aquisição e distribuição de alimentos destinados ao combate à fome no âmbito do Ministério do Desenvolvimento Social e Combate à Fome; ao programa Segurança de Voo e Controle do Espaço Aéreo Brasileiro; ao Plano Integrado de Enfrentamento ao Crack e outras Drogas; à atuação das Forças Armadas no Haiti no âmbito do programa Preparo e Emprego Combinado das Forças Armadas, dentre outras.

Interessante notar, entretanto, que nas últimas Leis de Diretrizes Orçamentárias (para os exercícios de 2012, 2013 e 2014), não constou a segunda categoria de despesas (“demais despesas ressalvadas”), tanto assim que o anexo nessas leis foi denominado

173 Conforme ZANCHIM, Kleber Luiz. Arts. 12 a 21. In CONTI, José Maurício (coord.). Orçamentos Públicos. A Lei $n^{\circ}$ 4.320/64 comentada. $2^{\text {a }}$ ed. São Paulo: Editora Revista dos Tribunais, 2010. 
“Despesas que não serão objeto de limitação de empenho, nos termos do artigo $9^{\circ}$, $\S 2^{\circ}$ da Lei de Responsabilidade Fiscal, por constituírem obrigações legais ou constitucionais da União".

$\mathrm{Na}$ LDO 2014 (Lei $\mathrm{n}^{\mathrm{o}}$ 12.919/2013) e LDO 2012 (Lei $\mathrm{n}^{\mathrm{o}}$ 12.465/2011), a presidência vetou a inclusão no Anexo das "demais despesas ressalvadas". O fundamento para o veto foi o seguinte:

\begin{abstract}
A exclusão de quaisquer dotações orçamentárias do cálculo da base contingenciável traz rigidez excessiva para o gerenciamento das finanças públicas, especialmente no tocante ao alcance da meta de resultado do superávit primário. Além disso, à medida que se reduzem, nessa base, as despesas discricionárias do Poder Executivo, aumenta proporcionalmente a participação dos Poderes Legislativo e Judiciário, do Ministério Público da União e da Defensoria Pública da União na limitação de empenho, o que poderá prejudicar o desempenho de suas funções, uma vez que, de forma geral, suas dotações destinam-se ao custeio de ações administrativas. ${ }^{174}$
\end{abstract}

Na LDO 2012, houve fundamento semelhante, com a adição de que "a não exclusão de determinada despesa da limitação de empenho não inviabiliza a sua execução, mas, ao contrário, cria condições para que o gestor possa otimizar os recursos disponíveis" $" 175$.

A despeito do veto e/ou não inclusão de demais despesas ressalvadas do contingenciamento, a LDO 2014 trouxe, na Seção em que trata da limitação orçamentária e financeira, disposição que determina ser "obrigatória a execução orçamentária e financeira, de forma equitativa, da programação incluída por emendas individuais em lei orçamentária", ao menos, "em montante correspondente a 1,2\% da receita corrente líquida realizada no exercício anterior" (artigo 52 da LDO 2014). Apesar da qualificação de obrigatória no caput, o $\S 2^{\circ}$ do artigo 52 faz uma ressalva, no sentido de que "não serão de execução obrigatória nos casos dos impedimentos de ordem técnica". Nesse caso, entretanto, não basta o mero contingenciamento por ato unilateral do Poder Executivo, é preciso enviar justificativa ao Poder Legislativo ou, caso o impedimento seja insuperável, enviar proposta de remanejamento.

A norma trazida pela LDO 2014 nada mais faz do que reforçar, com algumas especificações, o que o ordenamento jurídico, em linhas gerais, já determina, conforme

174 Mensagem de veto $\mathrm{n}^{\mathrm{o}}$ 595, de 24 de dezembro de 2013. Disponível em http://www.camara.gov.br/internet/comissao/index/mista/orca/ldo/ldo2014/Mensagem_Veto.pdf. Acesso em 27/05/2014.

175 Mensagem $\mathrm{n}^{\mathbf{o}}$ 312, de 12 de agosto de 2011. Disponível em http://www.camara.gov.br/internet/comissao/index/mista/orca/ldo/ldo2012/Mensagem_Veto.pdf. Acesso em 27/05/2014. 
visão apresentada neste capítulo. Ou seja, uma dotação apenas não será executada se houver uma impossibilidade justificada: não realização de receitas (pressuposto do contingenciamento). Ademais, é certo que deve o Poder Legislativo exercer controle sobre a (in)execução de todo o orçamento, e não apenas sobre o que lhe é de "interesse" direto, as emendas individuais.

A prática do contingenciamento tem, nesse sentido, forçado a criação de "suborçamentos", conforme interesses específicos e conforme níveis diferentes de execução. Ou seja, há uma disputa por ressalvar do contingenciamento (incluindo na Lei de Diretrizes Orçamentárias) algumas categorias de despesas, para que sejam de fato executadas. A prática demonstra que as despesas não ressalvadas na LDO terão menor possibilidade de serem realizadas.

Assim, poder-se-ia identificar categorias diferentes conforme a possibilidade de execução: o orçamento das despesas obrigatórias (obrigações legais e constitucionais), o orçamento das demais despesas ressalvadas (se a LDO assim fixar e não houver veto), o orçamento das despesas decorrentes de emendas individuais e, finalmente, o orçamento sujeito ao contingenciamento. Essas distinções fazem parecer que, para esse último "orçamento", o contingenciamento e a inexecução nem precisasse ser justificada, o que não configura a interpretação mais adequada das normas de Direito Financeiro.

Em resumo, o $\S 2^{\circ}$ do artigo $9^{\circ}$ da Lei de Responsabilidade Fiscal demonstra que não há apenas um limite para as hipóteses de aplicação do contingenciamento, há também limites relativos a quais despesas atingirá. Permite-se, de um lado, vedar a inexecução de despesas constitucionalmente (ou legalmente) protegidas; e, de outro lado, possibilita a criação de "sub-orçamentos" (com níveis de execução distintos), conforme interesses específicos e momentâneos.

2.3.5. O contingenciamento e o conflito entre os Poderes: $\S 3^{\circ}$ do artigo $9^{\circ}$ da Lei de Responsabilidade Fiscal

Conforme estabelece o caput do artigo $9^{\circ}$, o contingenciamento, a despeito de ser determinado pelo Poder Executivo, deve ser seguido pelos demais Poderes (Legislativo e Judiciário) e pelo Ministério Público. 
O Poder Executivo, responsável pela realização das receitas e pelo cumprimento das metas fiscais, aponta o montante necessário que deve ser contingenciado, o que é proporcionalizado para cada Poder, de acordo com o orçamento fixado para aquele ano.

Pretendendo regulamentar a relação do contingenciamento com os demais Poderes, o $\S 3^{\circ}$ do artigo $9^{\circ}$ da Lei de Responsabilidade Fiscal estabeleceu que, caso os Poderes Legislativo e Judiciário, além do Ministério Público, não promovam a limitação “indicada", o próprio Executivo poderia efetuar a limitação dos valores orçamentários dos demais Poderes. Eis o teor da norma:

$\S 3^{\circ}$. No caso de os Poderes Legislativo e Judiciário e o Ministério Público não promoverem a limitação no prazo estabelecido no caput, é o Poder Executivo autorizado a limitar os valores financeiros segundo os critérios fixados pela lei de diretrizes orçamentárias.

A justificativa para a intervenção está relacionada à competência do Executivo na gestão das finanças públicas e à sua responsabilidade para atingir as metas fiscais. Assim, segundo o que se extrai da norma, esses atributos do Executivo não poderiam ficar sujeitos a possíveis desmandos dos demais Poderes.

Ocorre que a constitucionalidade do $\S 3^{\circ}$ do artigo $9^{\circ}$ foi questionada no Supremo Tribunal Federal, sob o fundamento de violar a separação de poderes. Argumentou-se que a norma tornaria o Executivo um "superpoder", com a competência de intervir nos demais Poderes para suprir administrativamente o que estes deixaram de fazer. O Supremo Tribunal Federal, na Medida Cautelar na Ação Direta de Inconstitucionalidade $n^{\circ} 2.238^{176}$, reconheceu a inconstitucionalidade, em razão da possibilidade de interferência indevida do Poder Executivo sobre os demais. Assim, o referido parágrafo não está produzindo efeitos, já que houve deferimento da medida cautelar.

Cabe, aqui, uma breve do conflito que coloca, de um lado, a separação de poderes (incluindo nela a autonomia administrativa) e, de outro lado, a necessidade de que os Poderes contribuam para atingir as metas fiscais previstas e manter o "equilíbrio orçamentário".

De fato, há um problema na possibilidade de interferência do Executivo sobre os demais Poderes, limitando os valores indicados para contingenciamento. Conforme escreve José Maurício Conti, há razoabilidade na limitação de despesas para manter o equilíbrio orçamentário, entretanto, "em face da autonomia financeira do Poder Judiciário,

\footnotetext{
${ }^{176}$ BRASIL. Supremo Tribunal Federal. Pleno. Medida Cautelar na Ação Direta de Inconstitucionalidade $n^{\circ}$ 2.238-5/DF. Relator Ministro Ilmar Galvão. Relator para Acórdão Ministro Carlos Britto. Julgamento em 09/08/2007. Apenas houve apreciação em sede cautelar.
} 
claramente estabelecida no art. 99 da CF, não é aceitável atribuir competência ao Poder Executivo para efetivar a redução das suas despesas" ${ }^{177}$.

Ocorre que também haverá um problema se os Poderes não promoverem a limitação de empenho indicada pelo Executivo. Em caso de inobservância do contingenciamento, pode-se ter não apenas um conflito político entre os Poderes, mas também o descumprimento do próprio caput do artigo $9^{\circ}$ da Lei de Responsabilidade Fiscal, que determina que cada um dos Poderes deve promover sua limitação. Se a ferramenta do $\S 3^{\circ}$ não é passível de utilização (pela suspensão de seus efeitos), então como se faria cumprir a determinação do artigo $9^{\circ}$, caput da Lei de Reponsabilidade Fiscal? Como conciliar o "equilíbrio orçamentário", a gestão das finanças e a separação de poderes?

Esse debate foi travado, ainda que brevemente, durante a apreciação da constitucionalidade do $\S 3^{\circ}$ do artigo $9^{\circ}$ da Lei de Responsabilidade Fiscal ${ }^{178}$. Questionou o Ministro Nelson Jobim, diante da determinação do caput do mesmo artigo: “(...) se os Poderes e o Ministério Público, por ato próprio fixam os montantes nos trinta dias, mas mesmo assim não cumprem, como é que faz?".

Em resposta, o Ministro Sepúlveda Pertence aponta: “Não sei. E se o Poder Executivo não cumprir, Ministro, como é que faz? Isso se chama autonomia financeira, onde se podem cometer ilegalidades. Nenhum Poder será juiz do outro.”

Considerando que é o Executivo o Poder que sofreria o ônus (ao menos político e econômico) pela inobservância do contingenciamento pelos demais Poderes e possível descumprimento das metas fiscais, diante dessa situação, deveria ele acionar o Judiciário para fazer cumprir a limitação indicada, ou seja, para fazer com que os demais Poderes cumpram o artigo $9^{\circ}$, caput da Lei de Responsabilidade Fiscal? Ao mencionar outro caso, o Ministro Sepúlveda Pertence parece entender que essa seria a solução:

(...) Lembro-me de um caso que relatei, em que o Governador, salvo engano o do Estado de Tocantins, baixara um ato normativo segundo o qual, quando o vencimento dos Desembargadores superasse os do Supremo Tribunal Federal, o Executivo limitaria os repasses. E a nossa tese foi que não se discutia a constitucionalidade do conteúdo do decreto; mas o Governador jamais poderia ser o julgador e o executor de uma eventual ilegalidade cometida por outro Poder, que tem vias

\footnotetext{
${ }^{177}$ CONTI, José Maurício. A autonomia Financeira do Poder Judiciário. São Paulo: MP Editora, 2006, p. 100.

${ }^{178}$ Vide página 170 do acórdão da Medida Cautelar na Ação Direta de Inconstitucionalidade $\mathrm{n}^{\mathbf{0}} 2.238$ (BRASIL. Supremo Tribunal Federal. Pleno. Medida Cautelar na Ação Direta de Inconstitucionalidade $n^{\circ}$ 2.238-5/DF. Relator Ministro Ilmar Galvão. Relator para Acórdão Ministro Carlos Britto. Julgamento em 09/08/2007).
} 
constitucionais próprias, de impugnação (ADIn MC 691, 22.04.92, RTJ 140/797). ${ }^{179}$

Desta forma, para que se faça cumprir o contingenciamento pelos demais Poderes, deveria o ente interessado (Executivo) questionar a omissão do outro ente pelas vias constitucionais próprias (Judiciário), não sendo permitindo uma interferência administrativa direta do Executivo ${ }^{180}$. Embora não seja livre de problemas, parece ser esta a solução mais adequada para o problema.

2.3.6. Avaliação do cumprimento de metas: $\S 4^{\circ}$ e $\S 5^{\circ}$ do artigo $9^{\circ}$ da Lei de Responsabilidade Fiscal

Por último, analisa-se o $\S 4^{\circ}$ e o $\S 5^{\circ}$ do artigo $9^{\circ}$ da Lei de Responsabilidade Fiscal, os quais determinam que haja avaliação do cumprimento das metas fiscais e dos objetivos de política monetária, creditícia e cambial:

$\S 4^{\circ}$. Até o final dos meses de maio, setembro e fevereiro, o Poder Executivo demonstrará e avaliará o cumprimento das metas fiscais de cada quadrimestre, em audiência pública na comissão referida no $\S 10$ do art. 166 da Constituição ou equivalente nas Casas Legislativas estaduais e municipais.

$\S 5^{\circ}$. No prazo de noventa dias após o encerramento de cada semestre, o Banco Central do Brasil apresentará, em reunião conjunta das comissões temáticas pertinentes do Congresso Nacional, avaliação do cumprimento dos objetivos e metas das políticas monetária, creditícia e cambial, evidenciando o impacto e o custo fiscal de suas operações e os resultados demonstrados nos balanços.

\footnotetext{
${ }^{179}$ Ao observar um trecho da ementa do julgado mencionado pelo Ministro Sepúlveda Pertence, de fato o caminho proposto é o ingresso no Judiciário contra os abusos e ilegalidades na sua administração financeira: “(...) A administração financeira do Judiciário não esta imune ao controle, na forma da Constituição, da legalidade dos dispêndios dos recursos públicos; sujeita-se, não apenas a fiscalização do Tribunal de Contas e do Legislativo, mas também as vias judiciais de prevenção e repressão de abusos, abertas não só aos governantes, mas a qualquer do povo, incluídas as que dão acesso a jurisdição do Supremo Tribunal (CF, art. 102, I, n). O que não admite transigências e a defesa da independência de cada um dos Poderes do Estado, na área que lhe seja constitucionalmente reservada, em relação aos demais, sem prejuízo, obviamente, da responsabilidade dos respectivos dirigentes pelas ilegalidades, abusos ou excessos cometidos. (...)" (BRASIL. Supremo Tribunal Federal. Pleno. ADI 691 MC/TO. Relator Ministro Sepúlveda Pertence. Julgamento em 22/04/1992).

${ }^{180}$ De se mencionar, ainda, a existência de diversas ações judiciais ajuizadas pelos demais Poderes em face do Executivo, decorrente de "cortes" em seus orçamentos na consolidação da proposta orçamentária. Nesse sentido, vide, por exemplo BRASIL. Supremo Tribunal Federal. Decisão Monocrática na ADPF 240/DF. Relator Ministro Roberto Barroso. Julgamento em 14/10/2013). Vide, ainda, notícia veiculada pelo site do Supremo Tribunal Federal sobre o tema: "Ações questionam corte no orçamento do Judiciário e do MPU”, que menciona, além da ADPF 240, também o MS 30.896 (Disponível em http://www.stf.jus.br/portal/cms/verNoticiaDetalhe.asp?idConteudo=189790. Acesso em 11/08/2014). Nas ações mencionadas, houve inicialmente a concessão de liminar para que o Legislativo apreciasse as propostas originais de orçamento do Ministério Público e do Judiciário. Porém, houve perda superveniente do objeto, sem ter análise do mérito.
} 
Para fins do presente trabalho, importa destacar a preocupação da Lei de Responsabilidade no controle de metas fiscais, monetárias, creditícias e cambiais, bem como o papel central do contingenciamento como instrumento de seu cumprimento. $\mathrm{Ou}$ seja, o artigo $9^{\circ}$, caput e parágrafos, busca não apenas regular o contingenciamento, como também impor uma avaliação de seus resultados, em especial pela determinação de seu $\$ 4^{\circ}$.

No tocante ao $\S 5^{\circ}$, importa consignar, ainda, que ele também foi objeto de controle de constitucionalidade (em sede cautelar), sob o fundamento de que trataria de competência do Banco Central por lei complementar não específica, o que era vedado pela Constituição Federal $^{181}$. Entendeu o Plenário do Supremo Tribunal Federal que, no caso da norma em questão, agiria o Banco Central como executor da política econômica e não como órgão central do Sistema Financeiro Nacional, não havendo, portanto, inconstitucionalidade nesse ponto ${ }^{182}$.

Partindo dessas considerações, verifica-se que o contingenciamento (ou limitação de empenho e movimentação financeira) constitui um mecanismo fundamental para se alcançar o equilíbrio orçamentário, um dos objetivos estabelecidos pela Lei de Responsabilidade Fiscal, além de adequar o planejamento à execução. A necessidade de programação financeira para execução de despesas e a possibilidade de contingenciamento representam uma maior preocupação da legislação brasileira com o controle sobre os gastos públicos, demonstrando, ao menos em teoria, preocupação com o equilíbrio orçamentário e com a dívida pública. A Lei de Responsabilidade Fiscal, ao mesmo tempo em que exigiu a observância de metas de resultado fiscal na execução do orçamento, trouxe também mecanismos para que tais objetivos fossem alcançados, sendo o contingenciamento o principal deles. Exatamente por ser o principal mecanismo de alcance a essas metas, é que sua prática traz tantos problemas, o que se passa a ser analisado.

\footnotetext{
${ }^{181}$ Conforme interpretação do STF ao artigo 192 da Constituição Federal, em redação anterior à Emenda Constitucional $n^{\circ} 40 / 2003$.

${ }^{182}$ BRASIL. Supremo Tribunal Federal. Pleno. Medida Cautelar na Ação Direta de Inconstitucionalidade $\mathrm{n}^{\circ}$ 2.238-5/DF. Relator Ministro Ilmar Galvão. Relator para Acórdão Ministro Carlos Britto. Julgamento em $09 / 08 / 2007$.
} 


\section{A PRÁTICA DO CONTINGENCIAMENTO: ANÁLISE DE DADOS NO ÂMBITO DO ORÇAMENTO FEDERAL}

\subsection{Considerações iniciais sobre a prática do contingenciamento: as críticas da doutrina e os apontamentos dos meios de comunicação}

Restou verificado que o pressuposto para a aplicação do contingenciamento é que a realização de receita pode não comportar o cumprimento das metas fiscais. Ressalvou-se que, por envolver previsões, com base em uma série de variáveis complexas, não é tarefa fácil aferir a legalidade da utilização do mecanismo. Entretanto, é tarefa possível. Poderse-ia imaginar um cenário em que qualquer contingenciamento seria justificável, devido à própria abstração de seu requisito. Se fosse aceita tal premissa, seriam inúteis as disposições do artigo $9^{\circ}$ da Lei de Responsabilidade Fiscal. Tornam-se inúteis as próprias previsões de receita e fixação de despesas no orçamento. Não é essa a premissa mais adequada.

Nesse sentido, entende-se ser possível, com base na comparação de alguns dados, criticar a utilização do contingenciamento em face de seus parâmetros legais. Por exemplo, se a execução de despesa é significativamente mais afetada do que a arrecadação ou, ainda, se a inexecução não é devidamente motivada, sugere-se que a aplicação do contingenciamento não está observando os limites da Lei de Responsabilidade Fiscal.

Ademais, alguns comportamentos dos gestores também permitem aferir que o contingenciamento está distante de seus requisitos. Por exemplo, um contingenciamento logo no início do ano (preventivo) ou, ainda, a limitação e liberação de recursos destinados a conquistar apoio do Legislativo também indicam aplicação ilegal e distorcida do instituto. Outra hipótese é a de retomada do gasto sem qualquer relação de proporcionalidade com as restrições efetuadas, o que indica descumprimento do que determina a Lei de Responsabilidade Fiscal. Ainda, se o contingenciamento afetar os gastos mínimos obrigatórios, a exemplo do orçamento mínimo para saúde e educação, haverá inobservância de parâmetros legais e constitucionais.

A partir dessas considerações, pretende-se aqui verificar se, no âmbito federal, há uma relação mínima entre as condições para o contingenciamento e sua aplicação ou, ao contrário, se é possível identificar elementos que indiquem a inobservância das normas que o regulamentam.

Busca-se esse objetivo tanto a partir da análise de dados, quanto da análise da doutrina. Aliás, a pertinência da questão é justificada através das diversas críticas feitas 
pela doutrina, além das observações dos meios de comunicação acerca do contingenciamento no âmbito federal. Citam-se algumas dessas críticas e constatações acerca do funcionamento do contingenciamento, antes da análise de dados.

Observando a prática da execução orçamentária, Regis Fernandes de Oliveira verifica que, "após aprovado o orçamento, depois de tantas e prolongadas discussões, o governo baixa decreto estabelecendo, meses após, o contingenciamento de tantos bilhões". O que se vê, conforme constata o mencionado autor é o uso desmedido e genérico da previsão, com graves danos para a correta aplicação dos recursos: "se a lei definiu em que circunstância pode ocorrer e fixou o momento adequado para que ocorra, óbvio que trabalhar de outra forma é agredir o ordenamento jurídico" ${ }^{\text {183 }}$.

Com conclusão semelhante, Eduardo Bastos Furtado de Mendonça constata que o decreto competente por estabelecer a programação financeira e o cronograma mensal de desembolso tem servido para determinar o contingenciamento das previsões orçamentárias, dias após sua aprovação, além de outros contingenciamentos feitos ao longo do exercício fiscal, mediante novos decretos. A crítica apontada pelo autor é a de que muitas vezes a "liberação" dos recursos públicos acontece fora dos períodos previstos, dificultando a realização de um planejamento. Ainda, o mesmo autor ressalta a dificuldade no acompanhamento da execução orçamentária, embora haja muitas informações disponíveis nos sites da Presidência e do Senado: "a doutrina não fornece dados sistemáticos a respeito, o que certamente seria desejável”. Mesmo assim, considera que a informação sobre os excessivos contingenciamentos é de "conhecimento notório", havendo diversos exemplos que confirmam tal hipótese ${ }^{184}$.

Também segue essa linha Selene Peres Nunes. Ao analisar os efeitos do contingenciamento sobre a qualidade do gasto público, sugere a autora que não deveria ser o contingenciamento preventivo, mormente no âmbito do Governo Federal que, "ao invés de cortar na margem, corta-se tudo no início e, depois, vai-se liberando os limites aos poucos". Em sua opinião, tal mecanismo “trava a gestão, o que é ruim e não corresponde à interpretação original da LRF",185.

${ }^{183}$ OLIVEIRA, Regis Fernandes de. Curso de direito financeiro. $4^{\text {a }}$ ed., ver., atual e ampliada. São Paulo: Revista dos Tribunais, 2011, pp. 325-327.

${ }^{184}$ MENDONÇA, Eduardo Bastos Furtado de. Constitucionalização das Finanças Públicas no Brasil. Rio de Janeiro: Renovar, 2010, p. 92.

${ }^{185}$ NUNES, Selene Peres. Os 10 anos da LRF e o Projeto de Lei da Qualidade Fiscal. In Cadernos da Controladoria, Ano X, $\mathrm{n}^{\circ}$ 02. Rio de Janeiro, 2010, p. 40. Disponível em http://www7.rio.rj.gov.br/cgm/comunicacao/publicacoes/cadernos/edicoes/2010_09/anexos/caderno_09_201 0.pdf. Acesso em 04/06/2013. 
Vander Gontijo considera que, apesar de um instrumento necessário na execução orçamentária, o "processo utilizado pelo Poder Executivo para promover o contingenciamento apresenta falhas e os respectivos decretos presidenciais excedem aos termos dispostos na LRF"186. Segundo o autor, o uso do contingenciamento deve ser limitado à eventual frustração de receitas ${ }^{187}$. Se tal hipótese não ocorrer, não pode haver contingenciamento.

Destaca o mesmo autor que, na prática, o Executivo tem feito um contingenciamento com falhas e os montantes contingenciados têm sido inflados, por diversos motivos, dentre os quais, aponta: aumentos imprevistos nas despesas obrigatórias, créditos extraordinários abertos sem a correspondente fonte financiadora, pagamento de restos a pagar de exercícios anteriores, aumento do superavit primário após a aprovação do orçamento pelo Congresso $^{188}$. Veja-se que os motivos citados pelo autor são consequência de uma política orçamentária inadequada e da falta de planejamento do próprio Executivo. Há um ciclo perverso estimulado pelo próprio Executivo e a consequência é que "o governo faz contingenciamento mesmo quando não tem informação certa de que realmente houve arrecadação insuficiente" e "transforma um instrumento técnico em instrumento de negociação" 189 .

Decorrente desse ciclo, muitos estudiosos têm apontado para a existência de um "contingenciamento preventivo", ou seja, realizado antes de mesmo de haver informações suficientes sobre a não realização das receitas, mas decorrente, principalmente, pela política de geração de superavit primários:

Essa necessidade de geração de superávits primários, maiores até do que os especificados na Lei de Diretrizes Orçamentárias - LDO, e a priorização de pagamento de juros da dívida em detrimento da execução das políticas sociais, tem levado o governo a adotar o contingenciamento preventivo. No começo do exercício fiscal, são limitados os gastos de

\footnotetext{
186 GONTIJO, Vander. Orçamento impositivo, contingenciamento e transparência. In: Cadernos Aslegis, n.39, p. 61-72, jan/abr 2010, p. 61.

${ }^{187} \mathrm{Na}$ mesma linha, Carlos Otávio Ferreira de Almeida menciona relatório do TCU para atestar que a programação de gastos tem sido significativamente prejudicada pela aplicação do contingenciamento. E observa: "Pela letra da LRF, todavia, não deveria ser assim. O contingenciamento das despesas, isto é, a limitação de empenhos e movimentação financeira, deveria ocorrer apenas em caso de ameaça às metas de resultado primário ou nominal, por eventual insuficiência de receitas apurada bimestralmente, considerando a programação financeira e o cronograma de desembolso, a cargo do executivo" (ALMEIDA, Carlos Otávio Ferreira de. Planejamento Financeiro Responsável. In CONTI, José Maurício; SCAFF, Fernando Facury (coord.). Orçamentos Públicos e Direito Financeiro. São Paulo: Editora Revista dos Tribunais, 2011, p. 587). ${ }^{188}$ GONTIJO, Vander. Orçamento impositivo, contingenciamento e transparência. In: Cadernos Aslegis, n.39, p. 61-72, jan/abr 2010, p. 65.

${ }^{189}$ Ibidem, p. 69.
} 
diversos órgãos da administração direta. A liberação dos mesmos ocorre no decorrer do ano ${ }^{190}$.

Analisando a gestão orçamentária, Élida Graziane Pinto afirma que, apesar dos requisitos impostos pela LRF para justificar a limitação da despesa, "o administrador tem expandido as possibilidades de contingenciamento para atender, entre outras finalidades não evidenciadas perante o Legislativo, à necessidade de crescentes superavits primários”, que muitas vezes superam o previsto nas metas fiscais ${ }^{191}$. A mesma autora verifica, assim, uma prática de contingenciamentos sem comprovação de frustração de receitas e dos riscos de afetação das metas fiscais, incentivada pela majoração ou superação da meta. Se a meta alcançada for superior, "certamente terá havido contingenciamento de empenhos ou inexecução de políticas públicas sem correlação com o previsto no art. $9^{\circ}$ da LRF"192 ${ }^{\text {É o }}$ caso, portanto, de inexistência no motivo do ato administrativo de contingenciamento.

Embora a geração de superávit primário e o pagamento dos juros da dívida possa ser um dos objetivos da política fiscal e orçamentária do governo, não se justifica a utilização de um instrumento técnico sem vínculo com seus limites legais, a fim de alcançar esses objetivos de forma desmedida. Inevitável aqui dizer que a finalidade, ainda que possa ser economicamente desejável (em certa medida), não justifica a aplicação ilegal do contingenciamento. Isso sem considerar que há outros princípios e valores em jogo, assegurados constitucionalmente e que são suprimidos em razão desse objetivo primordialmente econômico.

Tratando do motivo e da motivação dos decretos de contingenciamento, os economistas do IPEA Mansueto Almeida, Alexandre Manoel e Helder Rebouças entendem que, "se houver desconformidade entre a realidade e o motivo declarado, torna-se possível a declaração de nulidade do ato pelo Poder Judiciário". E, após algumas considerações sobre as inconsistências dos contingenciamentos em 2011 e 2012, concluem que, no Brasil, há amplo espaço para a revisão da prática de contingenciamento de despesa, sendo que, na esfera jurídica, "exige-se que os decretos tenham motivação consistente e maior

\footnotetext{
${ }^{190}$ SADECK, Francisco; GERIN, Alvaro; VALLE, Bruno. Contingenciamento: necessidade tributária ou instrumento da política econômica. Nota Tecnica $\mathrm{n}^{\circ}$ 98. INESC, Maio/2005. Disponível em: http://www.inesc.org.br. Acesso em 10/03/2014.

${ }^{191}$ PINTO, Élida. Discricionariedade, contingenciamento e controle orçamentário. In: Revista de Gestão e Tecnologia. V. 6, $\mathrm{n}^{\circ}$ 2. 2006. Disponível em http://revistagt.fpl.edu.br/get/search/authors/view?firstName $=\%$ C3\%89lida\%20Graziane\&middleName=\&las tName $=$ Pinto\&affiliation=\&country $=$. Acesso em 05/05/2013

192 PINTO, Élida Graziane. Financiamento de Direitos Fundamentais: políticas públicas vinculadas, estabilização monetária e conflito distributivo no orçamento da União do pós-Plano Real. Belo Horizonte: Editora O Lutador, 2010, p. 308.
} 
legitimidade democrática, já que o contingenciamento transformou-se em poderoso instrumento de política fiscal, sem, no entanto, submeter-se aos crivos de deliberação pública ou parlamentar" ${ }^{\prime 193}$.

Prosseguindo nas constatações acerca da prática do contingenciamento, embora muitas vezes utilizando termos imprecisos, os meios de comunicação também têm demonstrado preocupação com o mecanismo (por vezes de denominado de "bloqueios, “cortes" ou "congelamentos") e a consequentemente liberação de recursos. Vejam-se alguns exemplos.

Em reportagem de 24/05/2012, a Folha de São Paulo relata a ocorrência de liberação atípica de recursos do orçamento destinados a atender emendas parlamentares no dia de "celebração de acordo que esvaziou as investigações da CPI do Cachoeira" "194. A liberação de recursos contingenciados para "controle" do Legislativo é uma suspeita recorrente, apontada também pela doutrina ${ }^{195}$, conforme se demonstrará no capítulo seguinte, em item que relaciona os efeitos do contingenciamento à legitimidade do gasto público.

Constatações dos meios de comunicação ajudam a identificar que o uso reiterado do contingenciamento no âmbito federal não é novidade do atual governo. Em Editorial de 31/05/2005, denominado "Contingenciamento Fatal”, a Folha de São Paulo aponta que tal mecanismo, "largamente utilizado pela administração Fernando Henrique Cardoso (...) adotado e ampliado no atual governo [Governo Lula], tem afetado demasiadamente os recursos que deveriam ser destinados para a educação de motoristas e prevenção de acidentes, impedindo a redução de acidentes no trânsito"196.

Problemas dessa natureza, relativos às dificuldades na implementação de políticas públicas e aos altos índices de inexecução, é tema recorrente no portal da associação

193 ALMEIDA, Mansueto; MANOEL, Alexandre; REBOUÇAS, Helder. "Os impasses do contingenciamento". Valor Econômico. São Paulo, 02 de março de 2012. Disponível em http://www.senado.gov.br/noticias/opiniaopublica/inc/senamidia/notSenamidia.asp?ud=20120302\&datNotici $\mathrm{a}=20120302 \& \operatorname{codNoticia}=663311 \&$ nomeOrgao $=\&$ nomeJornal $=$ Valor + Econ $\% \mathrm{C3} \% \mathrm{~B} 4 \mathrm{mico} \& \operatorname{codOrga0}=272$ 9\&tipPagina=1. Acesso em 12/03/2014.

${ }^{194}$ PATU, Gustavo; COLON, Leandro. Folha de São Paulo. Governo faz liberação atípica de verna no dia de acordão na CPI. Disponível em http://www1.folha.uol.com.br/fsp/poder/44658-governo-fez-liberacaoatipica-de-verba-no-dia-de-acordao-na-cpi.shtml. Acesso em 05/05/2013.

${ }_{195}$ Vide, por exemplo, CONTI, José Maurício. Emendas ao Orçamento e o Desequilíbrio de poderes. Disponível em http://www.conjur.com.br/2012-jul-03/contas-vista-emendas-orcamento-desequilibriopoderes. Acesso em 07/05/2013; MENDES, Marcos J. Sistema orçamentário brasileiro: planejamento, equilíbrio fiscal e qualidade do gasto público. Texto para discussão 39. Brasília: Consultoria Legislativa do Senado Federal, 2008; SABBAG. Cesar de Moraes. Breves Considerações sobre deficiências estruturais do sistema orçamentário brasileiro. In CONTI, José Maurício; SCAFF, Fernando Facury (coord.). Orçamentos Públicos e Direito Financeiro. São Paulo: Editora Revista dos Tribunais, 2011.

${ }_{196}$ FOLHA DE S PAULO. Contingenciamento Fatal. Disponível em http://www1.folha.uol.com.br/fsp/opiniao/fz3105200503.htm. Acesso em 05/05/2013. 
“Contas Abertas”, especializado em orçamento. São exemplos, no qual o contingenciamento é apontado como um dos, senão o principal responsável pela inexecução de políticas públicas: "Secretaria das Mulheres executou apenas $40 \%$ dos recursos em 2013" "197; "Programa de violência contra mulher aplica apenas $31 \%$ dos recursos de 2013"198; "Contingenciamento na Agricultura prejudica 'Defesa Agropecuária",199; "Dinheiro da Saúde só no papel - Ministério desembolsou apenas R\$ 1,9 bilhão do montante de $\mathrm{R} \$ 10$ bilhões previsto no Orçamento deste ano [2013]. Situação se repete em outras pastas da área social do governo"200; "Contingenciamento afeta programa para combate ao uso de drogas" "201; "Manifestações 'cobram' 160 bilhões que deixaram de ser investidos em $10 \operatorname{anos}^{202}$. Muitos outros exemplos poderiam ser mencionados, nas mais diversas áreas, bastando uma pesquisa no referido portal com o termo contingenciamento, para verificar os profundos efeitos desse mecanismo sobre as políticas públicas.

A bibliografia mencionada mostra que há graves problemas na prática relativa ao contingenciamento. São diversos os aspectos que demonstram haver uma utilização do mecanismo desvinculada de seus parâmetros legais. Pretende-se, no presente trabalho, dar mais um passo nas críticas doutrinárias, a partir da apresentação e análise de dados da execução orçamentária. Entende-se, aliás, que é esse o objetivo de um trabalho acadêmico no âmbito do Direito Financeiro: permitir que sejam dados mais alguns passos rumo à melhor compreensão de suas normas, à sua melhor aplicação e à sua concretização.

Esse o objetivo da revisão bibliográfica e também dos dados a seguir apresentados, os quais, se não encerram o assunto (esse nem poderia ser o objetivo), permitem uma melhor compreensão do uso inadequado do contingenciamento, desvinculado dos parâmetros da Constituição Federal e da Lei de Responsabilidade Fiscal. Analisados os

\footnotetext{
${ }^{197}$ MENEZES, Dielle. Secretaria de Políticas para Mulheres executou apenas 40\% dos recursos de 2013. Portal Contas Abertas. Disponível em http://www.contasabertas.com.br/website/arquivos/7931. Acesso em 25/03/2014.

${ }^{198}$ BELAT, Thaís. Programa de violência contra mulher aplica apenas $31 \%$ dos recursos de 2013. Portal Contas Abertas. Disponível em http://www.contasabertas.com.br/website/arquivos/7796. Acesso em 24/03/2014.

199 DUTRA, Marina. Contingenciamento na Agricultura prejudica "Defesa Agropecuária". Portal Contas Abertas. Disponível em http://www.contasabertas.com.br/website/arquivos/6599. Acesso em 24/03/2014.

200 ESTADO DE MINAS. Dinheiro da saúde só no papel. Portal Contas Abertas. Disponível em http://www.contasabertas.com.br/website/arquivos/sobrecontas/dinheiro-da-saude-so-no-papel. Acesso em 24/03/2014.

${ }^{201}$ MENEZES, Dielle. Contingenciamento afeta programa para combate ao uso de drogas. Portal Contas Abertas. Disponível em http://www.contasabertas.com.br/website/arquivos/520. Acesso em 24/03/2014.

${ }^{202}$ MENEZES, Dielle; DUTRA, Marina. Manifestações “cobram” R\$ 160 bilhões que deixaram de ser investidos em 10 anos. Portal Contas Abertas. Disponível em http://www.contasabertas.com.br/website/arquivos/552. Acesso em 24/03/2014.
} 
dados, serão discutidos os impactos na execução do gasto público, bem como as possibilidades de controle.

Passa-se, portanto, a analisar os decretos de contingenciamento dos últimos quatro $\operatorname{anos}(2010$ a 2013).

\subsection{Metodologia e análise dos dados sobre o contingenciamento}

Com o avanço da tecnologia e a consolidação do princípio da transparência, cada vez mais dados sobre a execução orçamentária passam a ser disponibilizados pelo Poder Público. Nem sempre, porém, tais dados permitem uma leitura precisa sobre os caminhos seguidos pela execução orçamentária. Em parte, pois, a precisão envolve cruzar um vasto número informações de diferentes fontes e que nem sempre adotam as mesmas categorias para designar receita, despesa, execução, empenho, liquidação, pagamento, restos a pagar, dentre outros. Em outra medida, pela própria influência dos mecanismos de flexibilização orçamentária, especialmente do contingenciamento (mas também dos créditos adicionais e dos remanejamentos), que tornam sinuoso o caminho do gasto público.

Feitas essas considerações, faz-se aqui uma análise de dados do orçamento federal que, além de ser o principal do país, estão disponíveis para consulta, com informações sobre o contingenciamento e sobre a execução orçamentária.

Neste capítulo, portanto, pretende-se apresentar um panorama geral da relação entre o contingenciamento e a execução orçamentária, razão pela qual se opta por apresentar os dados por órgão ${ }^{203}$.

Os dados foram retirados do Siga Brasil ou Portal do Orçamento ${ }^{204}$. O Siga Brasil consiste em um sistema de informações sobre elaboração e execução do orçamento público, sendo composto pela base de dados do SIAFI (Sistema Integrado de Administração Financeira do Governo Federal) ${ }^{205}$, organizados de forma distinta, com acesso por meio de uma única ferramenta de consulta. Dentre os dados que se encontram

\footnotetext{
${ }^{203}$ Nas tabelas, manteve-se a denominação utilizada no Siga Brasil. Assim, verifica-se que de um ano para outro pode haver algumas alterações na lista de órgãos. Por exemplo, no ano de 2013, estão na lista a Secretaria de Direitos Humanos, a Secretaria de Política para as mulheres e a Secretaria de Políticas de Promoção de Igualdade Racial, órgãos que não estavam nas planilhas dos anos anteriores.

${ }^{204}$ Disponível no endereço eletrônico http://www12.senado.gov.br/orcamento/sigabrasil (último acesso em 28/05/2014) ou no endereço eletrônico http://www12.senado.gov.br/orcamento/loa (último acesso em 28/05/2014).

205 O SIAFI "consiste no principal instrumento utilizado para registro, acompanhamento e controle da execução orçamentária, financeira e patrimonial do Governo Federal”. (https://www.tesouro.fazenda.gov.br/pt/siafi).
} 
disponíveis no Siga Brasil, o que interessa ao presente trabalho diz respeito àqueles da execução orçamentária. Os dados utilizados podem ser encontrados no endereço do Portal, mais especificamente a partir do item "Execução", referente a cada orçamento anual, no subitem "Programação Financeira/ Contingenciamento". Serão quatro tabelas para cada exercício, a seguir descritas.

Primeiro, para demonstrar os montantes contingenciados ao longo do exercício, utilizam-se os dados do Anexo I de cada "decreto de contingenciamento", que traz os "limites de movimentação e empenho". Esse anexo mostra o montante de despesa fixada em lei em comparação com aquela disponível para empenho/movimentação. No anexo em referência constam três tipos de informações de despesas, separadas em três conjuntos de colunas: "despesas obrigatórias", "outras despesas" e "despesa total". Para cada tipo, o anexo traz o valor orçamentário aprovado em lei (atualizado por créditos adicionais) e o valor disponível para execução.

Conforme exposto no capítulo anterior, o contingenciamento recai sobre despesas não obrigatórias ou "despesas discricionárias", e não deve atingir as despesas obrigatórias. É o que determina o $\S 2^{\circ}$ do artigo $9^{\circ}$ da Lei de Responsabilidade Fiscal ${ }^{206}$. O que se constata do Anexo I dos decretos de contingenciamento é justamente que na coluna de “despesas obrigatórias" o montante aprovado em lei é, via de regra, cem por cento disponibilizado. Por essa razão, para verificar os efeitos do contingenciamento, despreza-se esse valor ${ }^{207}$.

Para fins do presente trabalho, será elaborada tabela com os valores da coluna “demais despesas", ou seja, a coluna que contém as despesas não obrigatórias (ou “despesas discricionárias”). Se as despesas obrigatórias são totalmente disponibilizadas

\footnotetext{
${ }^{206} \mathrm{O} \quad \S 2^{\circ}$ do artigo $9^{\circ}$ da LRF dispõe que "não serão objeto de limitação as despesas que constituam obrigações constitucionais e legais do ente (...)". Conforme esclarecido no capítulo anterior, as despesas obrigatórias (ou decorrentes de obrigações legais e constitucionais), como o próprio nome diz, são aquelas para as quais há uma obrigação prevista em lei ou na Constituição (estabelecida antes mesmo da lei orçamentária). De se lembrar que as Leis de Diretrizes Orçamentárias trazem sempre um anexo no qual estão listadas as despesas obrigatórias não contingenciáveis, com a indicação da norma legal ou constitucional que a qualifica como obrigatória.

${ }^{207}$ De se apontar, entretanto, que já houve casos de contingenciamento de despesas obrigatórias, vedadas pela Lei de Responsabilidade Fiscal. Tanto assim que, em 2005, o Tribunal de Contas da União, proferiu acórdão para "9.2 recomendar aos Ministérios da Fazenda e do Planejamento, Orçamento e Gestão que adotem as providências cabíveis com vistas à não-inclusão nos futuros decretos de contingenciamento de despesas obrigatórias nos limites de movimentação e empenho fixados (...)" (BRASIL. Tribunal de Contas da União. Plenário. Processo no 012.781/2004-2. Acórdão n 183/2005. Relator Ministro Benjamin Zymler. Julgamento em 02/03/2005).
} 
para gastos, então é porque não são contingenciadas, em atendimento, portanto, $\S 2^{\circ}$ do artigo $9^{\circ}$ da Lei de Responsabilidade Fiscal ${ }^{208}$.

Nas tabelas elaboradas para a análise do contingenciamento, organizam-se tais dados de forma que se possam comparar os Decretos de Contingenciamento editados em cada exercício, indicando as despesas não obrigatórias (“outras despesas”) fixadas na Lei Orçamentária e atualizadas por créditos adicionais e/ou cancelamentos, o montante disponibilizado de tais despesas (conforme limites de empenho e movimentação financeira), e o percentual de disponibilidade dessas mesmas despesas em relação ao fixado em lei. De se esclarecer que serão desprezados os decretos de contingenciamento que não alteraram os limites de empenho e movimentação, ou seja, não alteraram o Anexo I do decreto original $^{209}$.

Em segundo lugar, para verificar a origem dos montantes contingenciados, utilizam-se os dados dos Relatórios de Avaliação Bimestral, também disponíveis no Portal do Orçamento ${ }^{210}$. Tais relatórios atendem ao disposto no artigo $165, \S 3^{\circ}$ da Constituição Federal de $1988^{211}$, regulamentado pelos artigos 52 e 53 da Lei de Responsabilidade Fiscal. Os relatórios amparam, ainda, o artigo $8^{\circ}$ da LRF, que determina o estabelecimento do cronograma mensal de desembolso, e também o artigo $9^{\circ}$ da mesma lei, referente ao contingenciamento. Trata-se, portanto, de relatório fundamental para a execução orçamentária.

Dentre as informações trazidas no Relatório de Avaliação Bimestral, utiliza-se o limite de empenho e movimentação financeira nele indicado. Além desse limite, o Relatório aponta para a distribuição deste para cada um dos Poderes ${ }^{212}$. Como o foco é a

\footnotetext{
${ }^{208}$ Se essas despesas obrigatórias são posteriormente e efetivamente executadas, não há como verificar pelo decreto de contingenciamento. O que se verifica no decreto, é que ele, via de regra, não pretende atingir essas despesas obrigatórias.

${ }^{209}$ Os decretos a que se faz referência no presente capítulo dispõem sobre a programação orçamentária e financeira e também estabelecem o cronograma mensal de desembolso do Poder Executivo. Assim, são de maneira geral decretos de execução orçamentária (e não apenas de contingenciamento). Trazem não apenas os limites de empenho e movimentação financeira (contingenciamento), mas também diversas outras disposições, a exemplo da "arrecadação e previsão de receitas", "resultado primário de empresas estatais federais", "limites para pagamento de restos a pagar", dentre outras disposições. Portanto, são editados decretos ao longo do ano que alteram outras disposições que não aquelas relativas ao Anexo I ("Limites de movimentação e empenho").

${ }^{210}$ Podem ser encontrados também no link "Relatórios de Avaliação Fiscal e de Cumprimento de Metas" do endereço: http://www.orcamentofederal.gov.br/informacoes-orcamentarias.

211 “Art. 165. (...)

$\S 3^{\circ}$ - O Poder Executivo publicará, até trinta dias após o encerramento de cada bimestre, relatório resumido da execução orçamentária."

${ }^{212}$ Conforme descrito no capítulo anterior, o $\S 3^{\circ}$ do artigo $9^{\circ}$ da Lei de Responsabilidade Fiscal está com eficácia suspensa em razão da cautelar deferida na Ação Direta de Inconstitucionalidade $n^{\circ}$ 2.238/DF. Em razão disso, não pode o Poder Executivo interferir diretamente nos demais Poderes (e no Ministério Público) para efetuar a limitação de empenho e movimentação financeira, caso estes não o façam por ato próprio.
} 
análise dos dados do Executivo, utilizou-se apenas o montante indicado para esse Poder. Via de regra, essa informação vem apontada em um item separado do Relatório, denominado "Montante da Limitação e Distribuição entre os Poderes" (ou "Redução/Ampliação/Manutenção dos Limites de Empenho e Movimentação Financeira”). Nesse item, já aparece qual o montante sugerido para o contingenciamento da execução orçamentária do Poder Executivo ${ }^{213}$. Na tabela elaborada, busca-se mostrar a evolução desses limites ao longo do exercício, para que seja possível compará-los com aqueles efetivamente determinados no Decreto.

De se esclarecer que os Relatórios publicados ao longo do ano, com exceção do primeiro, não trazem o valor específico do limite, mas a necessidade de reduzir, manter ou ampliá-lo. Por essa razão, na tabela, haverá uma linha com o montante a ser reduzido/ampliado e o total, considerando o limite de empenho e movimentação originalmente determinado. Verifica-se que o valor será negativo sempre que houver "ampliação dos limites", ou seja, diminui-se o montante contingenciado e aumenta-se o disponível. De outra parte, o valor será positivo, sempre que se indicar "redução do limite", ou seja, aumenta-se o contingenciado, reduzindo-se o disponível.

Em terceiro lugar, para verificar os efeitos do contingenciamento sobre a execução orçamentária, elabora-se tabela que mostra, por órgão, a execução das despesas discricionárias (constante no item "execução orçamentária"). Algumas considerações se mostram relevantes nesse ponto.

Os dados sobre execução de despesas são disponibilizados de diversas formas (por programas, por função, por subfunção, por unidade federativa, etc.). Selecionou-se a execução de despesas "por órgão", a fim de traçar um panorama geral. Selecionou-se, ainda, aquela que contém somente a "despesa discricionária", justamente em razão de que essa é a categoria sujeita ao contingenciamento. Não foi selecionada a planilha que apresenta a "despesa total", incluindo, portanto, despesas discricionárias e também despesas obrigatórias, porque as despesas obrigatórias são de execução obrigatória, e não poderiam ser objeto de contingenciamento. Como explicitado, nos decretos de

\footnotetext{
${ }^{213}$ Ressalta-se que o Relatório apenas sugere o montante que deve ser observado pelos demais Poderes, já que, atualmente, não é possível uma intervenção do Executivo (decorrente da suspensão dos efeitos do artigo $9^{\circ}, \S 3^{\circ}$ da Lei de Responsabilidade Fiscal).
} 
contingenciamento as ditas "despesas obrigatórias" não aparecem como limitadas para empenho e movimentação financeira ${ }^{214}$.

Ainda sobre a execução das despesas discricionárias, de se esclarecer que consta na planilha do Siga Brasil/Portal do Orçamento o denominado "percentual executado", obtido segundo os critérios oficiais, que é o resultado da seguinte equação:

$\%$ Executado = Total Pagamento/(Autorizado $+R P P a g o+R P$ a Pagar $)$

Ou seja, o total do pagamento é, no caso, a soma dos valores efetivamente pagos nos exercícios, considerando os restos a pagar dos exercícios anteriores pagos no exercício corrente ( $R P$ pago) e dos valores já inscritos em restos a pagar ( $R P$ a pagar).

De fato se trata de um percentual relevante para fins de análise da execução orçamentária. Mantém-se esse dado na tabela que se apresenta aqui. Entretanto, mostra-se relevante, para verificar os efeitos do contingenciamento sobre o que foi aprovado, apresentar o percentual empenhado/liquidado e o percentual pago, sem considerar os restos a pagar. Esclarece-se que o montante liquidado, segundo os demonstrativos de execução de despesa constantes no Portal Siga Brasil, equivale ao empenhado. Assim, na tabela a ser elaborada, constará (i) \% executado (metodologia do Portal Siga Brasil acima explicitada); (ii) \% empenhado/liquidado (cálculo do montante liquidado sobre o total autorizado); (iii) \% pago em relação ao empenhado/liquidado (cálculo do montante pago, sem considerar restos a pagar, sobre o que foi empenhado/liquidado); e (iv) \% pago em relação ao autorizado (cálculo do montante pago, sem considerar restos a pagar, sobre o que foi autorizado).

Por fim, e em quarto lugar, para comparar o comportamento da inexecução de despesas frente à arrecadação de receitas, apresenta-se tabela com os dados da "execução de receitas", que demonstra as receitas previstas em contraponto às receitas arrecadadas, indicando-se o percentual de arrecadação em face do previsto. Desta forma, verifica-se em que medida houve frustação na arrecadação.

Todas essas quatro tabelas serão apresentadas nos exercícios analisados, quais sejam, 2010, 2011, 2012 e 2013. Ao longo do texto, destacam-se alguns dados e são feitos alguns comentários para ressaltar os objetivos que se pretendem com as tabelas. Por fim,

\footnotetext{
${ }^{214}$ Reitera-se a determinação do artigo $9^{\circ}, \S 2^{\circ}$ da Lei de Responsabilidade Fiscal, bem como a observação já feita de que o Anexo I dos decretos de execução orçamentária, via de regra, não limitam a despesa obrigatória.

“§ $2^{\underline{0}}$ Não serão objeto de limitação as despesas que constituam obrigações constitucionais e legais do ente, inclusive aquelas destinadas ao pagamento do serviço da dívida, e as ressalvadas pela lei de diretrizes orçamentárias."
} 
apresentam-se algumas observações gerais sobre os efeitos do contingenciamento na execução orçamentária a partir dos dados.

Em suma, para cada exercício, seguir-se-á esta ordem:

- Primeira tabela: Dados comparativos entre os Decretos de Contingenciamento editados no exercício, contendo, por órgão, (i) as despesas não obrigatórias (“outras despesas") fixadas na Lei Orçamentária (atualizada pelos créditos adicionais e possíveis cancelamentos), (ii) as despesas não obrigatórias (“outras despesas”) disponíveis, conforme limites de empenho e movimentação financeira, e (iii) o percentual de disponibilidade das despesas não obrigatórias (“outras despesas") em relação ao fixado em lei.

- Segunda Tabela: Evolução (ampliação ou redução) dos limites de empenho e movimentação financeira indicados para o Executivo pelo Relatório de Avaliação Bimestral.

- Terceira Tabela: Dados da Execução Orçamentária das despesas discricionárias, contendo, por órgão, (i) percentual executado (metodologia do Siga Brasil); (ii) percentual empenhado/liquidado (em relação ao autorizado); (iii) percentual pago em relação ao empenhado/liquidado; e (iv) percentual pago em relação ao autorizado.

- Quarta Tabela: Execução de Receitas do exercício, indicando, por tipo, (i) a receita prevista, (ii) a receita arrecadada, e (iii) o percentual arrecadado em relação ao previsto.

\subsubsection{Exercício de 2010}

A fim de regulamentar a execução financeira da Lei Orçamentária de 2010 (Lei no 12.214, de 26/01/2010), foi editado, em 03 de fevereiro de 2010, o Decreto $n^{\circ}$ 7.094/10, trazendo em seu Anexo I os limites para empenho (contingenciamento) para o ano. $\mathrm{O}$ Anexo I foi alterado três vezes ao longo do exercício, pelo Decreto $\mathrm{n}^{\mathrm{o}}$ 7.144, de

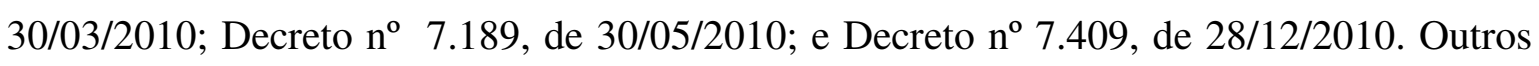
decretos foram editados ao longo do ano, mas não alteraram o Anexo I (alteraram outras previsões) e por isso não estão sendo considerados.

Quanto ao primeiro decreto de contingenciamento de 2010 (Decreto $\mathrm{n}^{\mathrm{o}}$ 7.094/10), necessário esclarecer que, em seu Anexo I, a norma traz duas limitações de empenho, uma que seria válida até março e outra válida até dezembro. O que se pode extrair é que a limitação até março parece provisória, tanto que no próprio mês de março já adveio outro 
decreto alterando os limites. Ainda, a limitação até dezembro disponibilizava $100 \%$ das despesas previstas, ou seja, de março até o final do ano, todos os recursos previstos seriam gastos, segundo o referido decreto. Desta feita, considerar-se-ão apenas os três decretos que a ele se seguiram. Conforme já explicitado, a planilha a seguir apresenta os valores extraídos da coluna "demais despesas" (despesas não obrigatórias), uma vez que para as despesas obrigatórias o disponibilizado é de cem por cento.

Tabela 1. Dados comparativos entre os Decretos de Contingenciamento editados no exercício de 2010, contendo, por órgão, (i) as despesas não obrigatórias ("outras despesas") fixadas na Lei Orçamentária (acrescida de créditos adicionais), (ii) as despesas não obrigatórias ("outras despesas") disponíveis, conforme limites de empenho e movimentação financeira, e (iii) o percentual de disponibilidade das despesas não obrigatórias ("outras despesas") em relação ao fixado em lei.

\begin{tabular}{|c|c|c|c|c|c|c|c|c|c|}
\hline \multirow[b]{2}{*}{ Órgão } & \multicolumn{3}{|c|}{ Decreto 7.144 (Março/2010) } & \multicolumn{3}{|c|}{ Decreto 7.189 (Maio/2010) } & \multicolumn{3}{|c|}{ Decreto 7.409 (Dezembro/2010) } \\
\hline & $\begin{array}{l}\text { Despesa } \\
\text { em Lei }\end{array}$ & $\begin{array}{c}\text { Despesa } \\
\text { Disponível }\end{array}$ & $\%$ & $\begin{array}{l}\text { Despesa } \\
\text { em Lei }\end{array}$ & $\begin{array}{c}\text { Despesa } \\
\text { Disponível }\end{array}$ & $\%$ & $\begin{array}{l}\text { Despesa em } \\
\text { Lei }\end{array}$ & $\begin{array}{c}\text { Despesa } \\
\text { Disponível }\end{array}$ & $\%$ \\
\hline $\begin{array}{l}\text { PRESIDENCIA DA } \\
\text { REPUBLICA }\end{array}$ & 3.728 .724 & 3.247 .421 & $87 \%$ & 3.737 .424 & 3.001 .302 & $80 \%$ & 3.794 .809 & 3.240 .133 & $85 \%$ \\
\hline $\begin{array}{c}\text { VICE- } \\
\text { PRESIDÊNCIA DA } \\
\text { REPÚBLICA }\end{array}$ & 3.729 & 2.500 & $67 \%$ & 3.729 & 2.474 & $66 \%$ & 3.729 & 2.787 & $75 \%$ \\
\hline $\begin{array}{c}\text { ADVOCACIA } \\
\text { GERAL DA UNIÃO }\end{array}$ & 277.917 & 194.000 & $70 \%$ & 277.917 & 140.685 & $51 \%$ & 277.917 & 238.645 & $86 \%$ \\
\hline $\begin{array}{l}\text { MINISTERIO DA } \\
\text { AGRICULTURA, } \\
\text { PECUARIA E } \\
\text { ABASTECIMENTO }\end{array}$ & 2.606 .860 & 1.222 .503 & $47 \%$ & 2.606 .860 & 1.429 .488 & $55 \%$ & 2.734 .460 & 2.065 .062 & $76 \%$ \\
\hline $\begin{array}{c}\text { MINISTERIO DA } \\
\text { CIENCIA E } \\
\text { TECNOLOGIA }\end{array}$ & 6.055 .464 & 5.720 .593 & $94 \%$ & 6.055 .464 & 5.670 .497 & $94 \%$ & 6.122 .935 & 5.709 .100 & $93 \%$ \\
\hline $\begin{array}{l}\text { MINISTERIO DA } \\
\text { FAZENDA }\end{array}$ & 3.420 .456 & 2.899 .619 & $85 \%$ & 3.420 .456 & 2.066 .866 & $60 \%$ & 3.406 .055 & 2.882 .260 & $85 \%$ \\
\hline $\begin{array}{l}\text { MINISTERIO DA } \\
\text { EDUCACAO }\end{array}$ & 17.092 .239 & 15.974 .882 & $93 \%$ & 17.092.239 & 14.332 .423 & $84 \%$ & 17.824 .893 & 14.850 .910 & $83 \%$ \\
\hline $\begin{array}{l}\text { MINISTERIO DO } \\
\text { DESENVOLVIMEN } \\
\text { TO, INDÚSTRIA E } \\
\text { COMERCIO } \\
\text { EXTERIOR }\end{array}$ & 1.013 .250 & 550.001 & $54 \%$ & 1.013 .250 & 568.352 & $56 \%$ & 1.038 .160 & 684.216 & $66 \%$ \\
\hline $\begin{array}{l}\text { MINISTERIO DA } \\
\text { JUSTICA }\end{array}$ & 3.729 .811 & 2.662 .479 & $71 \%$ & 3.729 .811 & 2.628 .083 & $70 \%$ & 3.798 .911 & 2.881 .629 & $76 \%$ \\
\hline $\begin{array}{l}\text { MINISTERIO DE } \\
\text { MINAS E ENERGIA }\end{array}$ & 1.059 .820 & 786.423 & $74 \%$ & 1.059 .820 & 707.435 & $67 \%$ & 1.070 .114 & 610.524 & $57 \%$ \\
\hline $\begin{array}{l}\text { MINISTERIO DA } \\
\text { PREVIDENCIA } \\
\text { SOCIAL }\end{array}$ & 1.743 .723 & 1.300 .000 & $75 \%$ & 1.743 .723 & 1.234 .919 & $71 \%$ & 1.829 .862 & 1.647 .121 & $90 \%$ \\
\hline $\begin{array}{l}\text { MINISTERIO DAS } \\
\text { RELACOES } \\
\text { EXTERIORES }\end{array}$ & 1.224 .785 & 812.000 & $66 \%$ & 1.224 .785 & 809.216 & $66 \%$ & 1.224 .785 & 962.356 & $79 \%$ \\
\hline
\end{tabular}




\begin{tabular}{|c|c|c|c|c|c|c|c|c|c|}
\hline $\begin{array}{l}\text { MINISTERIO DA } \\
\text { SAUDE }\end{array}$ & 12.132 .637 & 11.146 .425 & $92 \%$ & 12.132 .637 & 10.627 .057 & $\mathbf{8 8 \%}$ & 12.152 .954 & 9.897 .276 & $81 \%$ \\
\hline $\begin{array}{l}\text { MINISTERIO DO } \\
\text { TRABALHO E } \\
\text { EMPREGO }\end{array}$ & 1.349 .180 & 755.000 & $56 \%$ & 1.349 .180 & 749.058 & $56 \%$ & 1.361 .780 & 934.228 & $69 \%$ \\
\hline $\begin{array}{l}\text { MINISTERIO DOS } \\
\text { TRANSPORTES }\end{array}$ & 14.608 .633 & 13.228 .329 & $91 \%$ & 14.608 .633 & 12.308 .954 & $84 \%$ & 17.186 .149 & 15.099 .028 & $88 \%$ \\
\hline $\begin{array}{l}\text { MINISTERIO DAS } \\
\text { COMUNICACOES }\end{array}$ & 472.164 & 275.000 & $\mathbf{5 8 \%}$ & 472.164 & 195.191 & $41 \%$ & 506.678 & 301.905 & $60 \%$ \\
\hline $\begin{array}{l}\text { MINISTERIO DA } \\
\text { CULTURA }\end{array}$ & 1.806 .140 & 780.000 & $43 \%$ & 1.806 .140 & 623.478 & $35 \%$ & 1.816 .140 & 1.088 .343 & $60 \%$ \\
\hline $\begin{array}{l}\text { MINISTERIO DO } \\
\text { MEIO AMBIENTE }\end{array}$ & 824.779 & 530.000 & $64 \%$ & 824.779 & 432.649 & $52 \%$ & 867.268 & 598.060 & $69 \%$ \\
\hline $\begin{array}{l}\text { MINISTERIO DO } \\
\text { PLANEJAMENTO, } \\
\text { ORCAMENTO E } \\
\text { GESTAO }\end{array}$ & 2.452 .064 & 2.000 .000 & $82 \%$ & 2.452 .064 & 1.721 .855 & $70 \%$ & 2.452 .714 & 2.262 .884 & $92 \%$ \\
\hline $\begin{array}{l}\text { MINISTERIO DO } \\
\text { DESENVOLVIMEN } \\
\text { TO AGRARIO }\end{array}$ & 3.183 .279 & 2.000 .000 & $63 \%$ & 3.183 .279 & 2.029 .006 & $64 \%$ & 3.187 .679 & 2.190 .295 & $69 \%$ \\
\hline $\begin{array}{l}\text { MINISTERIO DO } \\
\text { ESPORTE }\end{array}$ & 1.523 .897 & 300.000 & $20 \%$ & 1.523 .897 & 477.030 & $31 \%$ & 2.099 .597 & 992.038 & $47 \%$ \\
\hline $\begin{array}{l}\text { MINISTERIO DA } \\
\text { DEFESA }\end{array}$ & 14.165 .582 & 8.261 .173 & $\mathbf{5 8 \%}$ & 14.165 .582 & 8.753 .621 & $62 \%$ & 14.003 .636 & 12.635 .735 & $90 \%$ \\
\hline $\begin{array}{l}\text { MINISTERIO DA } \\
\text { INTEGRACAO } \\
\text { NACIONAL }\end{array}$ & 5.161 .286 & 3.324 .347 & $64 \%$ & 5.161 .286 & 3.478 .557 & $67 \%$ & 5.232 .709 & 3.549 .868 & $68 \%$ \\
\hline $\begin{array}{l}\text { MINISTERIO DO } \\
\text { TURISMO }\end{array}$ & 4.181 .620 & 621.795 & $15 \%$ & 4.204 .950 & 1.188 .448 & $28 \%$ & 4.267 .150 & 2.193 .945 & $51 \%$ \\
\hline $\begin{array}{c}\text { MINISTERIO DO } \\
\text { DESENVOLVIMEN } \\
\text { TO SOCIAL E } \\
\text { COMBATE À FOME }\end{array}$ & 3.388 .470 & 3.183 .529 & $94 \%$ & 3.441 .470 & 3.030 .297 & $88 \%$ & 3.516 .903 & 3.218 .497 & $92 \%$ \\
\hline $\begin{array}{l}\text { MINISTERIO DAS } \\
\text { CIDADES }\end{array}$ & 14.755 .078 & 11.883 .458 & $81 \%$ & 14.822 .478 & 11.827 .320 & $80 \%$ & 15.507.917 & 12.423 .842 & $80 \%$ \\
\hline $\begin{array}{l}\text { MINISTERIO DA } \\
\text { PESCA E } \\
\text { AQÜICULTURA }\end{array}$ & 780.459 & 180.000 & $23 \%$ & 780.459 & 177.769 & $23 \%$ & 788.859 & 285.160 & $36 \%$ \\
\hline $\begin{array}{c}\text { ENCARGOS } \\
\text { FINANCEIROS DA } \\
\text { UNIAO }\end{array}$ & 1.278 .728 & 1.223 .585 & $96 \%$ & 1.278 .728 & 1.207 .584 & $94 \%$ & 1.278 .108 & 611.761 & $48 \%$ \\
\hline $\begin{array}{c}\text { TRANSFERENCIAS } \\
\text { A ESTADOS, } \\
\text { DISTRITO } \\
\text { FEDERAL E } \\
\text { MUNICIPIOS }\end{array}$ & 172.757 & 11.380 & $7 \%$ & 172.757 & 11.380 & $7 \%$ & 172.757 & 9.880 & $6 \%$ \\
\hline TOTAL OFICIAL & 124.320 .771 & 95.196 .442 & $77 \%$ & 124.473 .201 & 91.514 .994 & $74 \%$ & 129.652 .867 & 104.189 .026 & $80 \%$ \\
\hline
\end{tabular}

Fonte: Anexo I do Decreto $\mathrm{n}^{\circ}$ 7.144/2010, e alterações procedidas pelo Decreto 7.189/2010 e pelo Decreto 7.409/2010 (foram considerados apenas os Decretos que alteraram a limitação de empenho e movimentação financeira) (elaborada pelo autor).

Desde o primeiro decreto já se verificam limitações consideráveis, destacando-se órgãos com mais de 50\% indisponibilizado (Ministérios da Cultura, Esporte, Turismo, por 
exemplo). Embora do primeiro para o último Decreto, aumentou-se a despesa total disponível, cada órgão sofreu um impacto distinto: alguns com relevante aumento dos limites, outros com manutenção e outros com relevante redução. Vejam-se alguns exemplos: o Ministério da Educação tinha 93\% disponível, percentual que caiu para 84\% e depois para $83 \%$. O Ministério do Esporte seguiu um aumento de 20\%, para 31\%, e depois para $47 \%$ de despesas disponíveis. Já o Ministério das Cidades manteve percentuais estáveis, foi de $81 \%$ para $80 \%$, mantendo-se em $80 \%$ no último período. O Ministério da Fazenda sofreu uma limitação drástica do primeiro para o segundo decreto, de $85 \%$ para $60 \%$, mas depois retornou aos $85 \%$ no último decreto (parece ter ocorrido também um cancelamento de dotação prevista em lei inicialmente). Tal comportamento demonstra uma dificuldade em acompanhar o gasto, bem como de realizar minimamente um planejamento adequado para a execução orçamentária.

É certo que não há a retomada proporcional prevista no artigo $9^{\circ}, \S 1^{\circ}$, da Lei de Responsabilidade Fiscal. Essa proporcionalidade é considerada apenas entre os Poderes, mas não internamente ao Poder. Ou seja, quando houve redução ou ampliação dos limites, fez-se proporcionalmente ao orçamento de cada Poder, mas não considerando os órgãos internos de cada um.

Seguindo na análise, verifica-se que os montantes a serem contingenciados foram determinados, e alterados ao longo do ano, pelas indicações dos Relatórios Bimestrais de Avaliação, conforme tabela abaixo:

Tabela 2. Evolução (ampliação ou redução) dos limites de empenho e movimentação financeira indicados para o Executivo pelo Relatório de Avaliação Bimestral em 2010. Em milhões.

\begin{tabular}{lccccc}
\hline & $\mathbf{1}^{\mathbf{0}}$ Bimestre & $\mathbf{2}^{\mathbf{0}}$ Bimestre & $\mathbf{3}^{\mathbf{0}}$ Bimestre & $\mathbf{4}^{\mathbf{0}}$ Bimestre & $\mathbf{5}^{\mathbf{0}}$ Bimestre \\
\hline $\begin{array}{c}\text { Ampliação/Redução } \\
\text { sugerido para a } \\
\begin{array}{c}\text { limitação de empenho } \\
\text { e movimentação } \\
\text { financeira do } \\
\text { Executivo }\end{array}\end{array}$ & $\mathrm{R} \$ 21.459,80$ & $\mathrm{R} \$ 7.488,90$ & $-\mathrm{R} \$ 2.506,50$ & $-\mathrm{R} \$ 1.701,00$ & $-\mathrm{R} \$ 8.319,10$ \\
\hline & $\mathrm{R} \$ 21.459,80$ & $\mathrm{R} \$ 28.948,70$ & $\mathrm{R} \$ 26.442,20$ & $\mathrm{R} \$ 24.741,20$ & $\mathrm{R} \$ 16.422,10$ \\
\hline
\end{tabular}

Fonte: Relatórios de Avaliação Bimestral do exercício de 2010 (elaborado pelo autor).

Depreende-se que os montantes a serem limitados são maiores nos decretos do que o que efetivamente indicado pelos Relatórios de Avaliação. Em março, enquanto o Relatório do $1^{\circ}$ Bimestre indicava a limitação de $\mathrm{R}$ \$21.459,8 milhões para o Executivo, o 
Decreto $\mathrm{n}^{\mathrm{o}} 7.144$, de março, limitou 29.124,00 milhões, ou seja quase oito bilhões a mais. O Relatório do $2^{\circ}$ Bimestre determinou que fosse reduzido o disponível, totalizando uma limitação de R\$ 28.948,00 milhões. O Decreto editado em Maio de 2010 limitou em 32 bilhões, quase 4 bilhões a mais. Os relatórios seguintes determinaram ampliação do disponível, sendo certo que no $5^{\circ}$ bimestre o valor a ser limitado deveria ser de 16 bilhões. Porém, no decreto editado em dezembro, o limite ficou em $\mathrm{R} \$ 25.463,00$ bilhões, praticamente 9 bilhões de diferença. Com relação ao exercício de 2010, é possível concluir que os decretos não acompanharam os indicativos dos Relatórios Bimestrais.

Ainda, os significativos montantes contingenciados se refletem nos baixos percentuais de execução das despesas discricionárias do Executivo no ano em questão, com destaque especial para alguns órgãos, conforme se verifica da planilha abaixo, que contém as despesas discricionárias de 2010:

Tabela 3. Dados da Execução Orçamentária das despesas discricionárias em 2010, contendo, por órgão, (i) percentual executado (metodologia do Siga Brasil); (ii) \% empenhado/liquidado (em relação ao autorizado); (iii) percentual pago em relação ao empenhado/liquidado; e (iv) percentual pago em relação ao autorizado.

\begin{tabular}{|c|c|c|c|c|}
\hline Órgão (Cod/Desc) & \% Executado & \% Liquidado & $\begin{array}{c}\text { \% Pago (sobre } \\
\text { liquidado) }\end{array}$ & $\begin{array}{c}\% \text { Pago (sobre } \\
\text { autorizado) }\end{array}$ \\
\hline $\begin{array}{l}\text { PRESIDENCIA DA } \\
\text { REPUBLICA }\end{array}$ & $49,38 \%$ & $83 \%$ & $51 \%$ & $43 \%$ \\
\hline $\begin{array}{l}\text { MINISTERIO DA } \\
\text { AGRICULTURA, } \\
\text { PECUARIA E } \\
\text { ABASTECIMENTO }\end{array}$ & $42,54 \%$ & $80 \%$ & $40 \%$ & $32 \%$ \\
\hline $\begin{array}{l}\text { MINISTERIO DA CIENCIA } \\
\text { E TECNOLOGIA }\end{array}$ & $60,06 \%$ & $94 \%$ & $63 \%$ & $59 \%$ \\
\hline $\begin{array}{l}\text { MINISTERIO DA } \\
\text { FAZENDA }\end{array}$ & $68,08 \%$ & $88 \%$ & $75 \%$ & $66 \%$ \\
\hline $\begin{array}{l}\text { MINISTERIO DA } \\
\text { EDUCACAO }\end{array}$ & $64,00 \%$ & $87 \%$ & $74 \%$ & $64 \%$ \\
\hline $\begin{array}{c}\text { MINISTERIO DO } \\
\text { DESENVOLVIMENTO, } \\
\text { INDÚSTRIA E COMERCIO } \\
\text { EXTERIOR }\end{array}$ & $60,18 \%$ & $70 \%$ & $85 \%$ & $60 \%$ \\
\hline MINISTERIO DA JUSTICA & $56,23 \%$ & $75 \%$ & $71 \%$ & $53 \%$ \\
\hline $\begin{array}{l}\text { MINISTERIO DE MINAS E } \\
\text { ENERGIA }\end{array}$ & $38,97 \%$ & $56 \%$ & $60 \%$ & $34 \%$ \\
\hline $\begin{array}{c}\text { MINISTERIO DA } \\
\text { PREVIDENCIA SOCIAL }\end{array}$ & $78,10 \%$ & $91 \%$ & $84 \%$ & $77 \%$ \\
\hline $\begin{array}{c}\text { MINISTERIO DAS } \\
\text { RELACOES EXTERIORES }\end{array}$ & $76,10 \%$ & $79 \%$ & $96 \%$ & $76 \%$ \\
\hline MINISTERIO DA SAUDE & $79,73 \%$ & $96 \%$ & $89 \%$ & $85 \%$ \\
\hline $\begin{array}{c}\text { MINISTERIO DO } \\
\text { TRABALHO E EMPREGO }\end{array}$ & $49,47 \%$ & $70 \%$ & $64 \%$ & $45 \%$ \\
\hline
\end{tabular}




\begin{tabular}{|c|c|c|c|c|}
\hline $\begin{array}{l}\text { MINISTERIO DOS } \\
\text { TRANSPORTES }\end{array}$ & $47,15 \%$ & $88 \%$ & $47 \%$ & $41 \%$ \\
\hline $\begin{array}{l}\text { MINISTERIO DAS } \\
\text { COMUNICACOES }\end{array}$ & $26,83 \%$ & $74 \%$ & $30 \%$ & $22 \%$ \\
\hline $\begin{array}{l}\text { MINISTERIO DA } \\
\text { CULTURA }\end{array}$ & $37,11 \%$ & $57 \%$ & $51 \%$ & $29 \%$ \\
\hline $\begin{array}{c}\text { MINISTERIO DO MEIO } \\
\text { AMBIENTE }\end{array}$ & $54,49 \%$ & $63 \%$ & $86 \%$ & $54 \%$ \\
\hline $\begin{array}{c}\text { MINISTERIO DO } \\
\text { PLANEJAMENTO, } \\
\text { ORCAMENTO E GESTAO }\end{array}$ & $61,59 \%$ & $81 \%$ & $76 \%$ & $61 \%$ \\
\hline $\begin{array}{c}\text { MINISTERIO DO } \\
\text { DESENVOLVIMENTO } \\
\text { AGRARIO }\end{array}$ & $44,40 \%$ & $65 \%$ & $59 \%$ & $38 \%$ \\
\hline MINISTERIO DO ESPORTE & $17,98 \%$ & $49 \%$ & $23 \%$ & $11 \%$ \\
\hline MINISTERIO DA DEFESA & $63,43 \%$ & $88 \%$ & $70 \%$ & $61 \%$ \\
\hline $\begin{array}{c}\text { MINISTERIO DA } \\
\text { INTEGRACAO NACIONAL }\end{array}$ & $39,86 \%$ & $78 \%$ & $46 \%$ & $36 \%$ \\
\hline MINISTERIO DO TURISMO & $19,01 \%$ & $55 \%$ & $25 \%$ & $14 \%$ \\
\hline $\begin{array}{c}\text { MINISTERIO DO } \\
\text { DESENVOLVIMENTO } \\
\text { SOCIAL E COMBATE À } \\
\text { FOME }\end{array}$ & $94,05 \%$ & $98 \%$ & $98 \%$ & $96 \%$ \\
\hline $\begin{array}{l}\text { MINISTERIO DAS } \\
\text { CIDADES }\end{array}$ & $20,81 \%$ & $81 \%$ & $16 \%$ & $13 \%$ \\
\hline $\begin{array}{l}\text { MINISTERIO DA PESCA E } \\
\text { AQÜICULTURA }\end{array}$ & $19,35 \%$ & $39 \%$ & $50 \%$ & $19 \%$ \\
\hline $\begin{array}{c}\text { ENCARGOS FINANCEIROS } \\
\text { DA UNIAO }\end{array}$ & $42,90 \%$ & $44 \%$ & $96 \%$ & $43 \%$ \\
\hline $\begin{array}{c}\text { TRANSFERENCIAS A } \\
\text { ESTADOS, DISTRITO } \\
\text { FEDERAL E MUNICIPIOS }\end{array}$ & $64,19 \%$ & $96 \%$ & $100 \%$ & $96 \%$ \\
\hline $\begin{array}{l}\text { OPERACOES OFICIAIS DE } \\
\text { CREDITO }\end{array}$ & $45,25 \%$ & $98 \%$ & $0 \%$ & $55 \%$ \\
\hline $\begin{array}{l}\text { RESERVA DE } \\
\text { CONTINGENCIA }\end{array}$ & $0 \%$ & $0 \%$ & $0 \%$ & $0 \%$ \\
\hline TOTAL & $59,28 \%$ & $86 \%$ & $71 \%$ & $61 \%$ \\
\hline
\end{tabular}

Fonte: Portal Siga Brasil - Link: Execução Orçamentária - Subitem: Programação Financeira/ Contingenciamento - Planilha: "Despesa Discricionária Executivo - Fiscal e Seguridade - 2010”. (adaptada pelo autor).

Embora o percentual de empenho/liquidação tenha tido um percentual relativamente alto, ainda que bem abaixo do total aprovado, os percentuais de pagamentos foram significativamente menores, demonstrando que o Executivo tem empenhado mais recursos do que efetivamente planeja ou consegue pagar no exercício.

Demonstra-se, novamente, que cada órgão tem um comportamento específico, sendo que alguns órgãos ficam com percentuais muito baixos, seja em montante 
empenhado, seja em montante pago. Em outros órgãos, os percentuais são altos, em disparidade inclusive com a execução de receitas. Por exemplo, o Ministério do Desenvolvimento Social e Combate à Fome alcançou 98\% de empenho/liquidação e 96\% de pago em relação ao autorizado ${ }^{215}$. Porém, os Ministérios de Minas e Energia (com 56\% de empenhado e $34 \%$ pago) e da Cultura (com 57\% empenhado e $29 \%$ pago) ficaram com percentuais bastante baixos. Assim, olhando para o percentual de execução (conforme metodologia oficial) treze órgãos ficaram abaixo de 50\%, o que demonstra um grave equívoco de planejamento.

Quando se olha para a execução das receitas, o quadro que se tem é razoavelmente distinto do que se vê nas despesas, com $84 \%$ da receita total prevista sendo arrecadada. $\mathrm{Ou}$ seja, há uma distinção entre o comportamento da arrecadação (receita) e o da execução (despesa):

Tabela 4. Execução de Receitas do exercício de 2010, indicando, por tipo, (i) a receita prevista, (ii) a receita arrecadada, e (iii) o percentual arrecadado em relação ao previsto.

\begin{tabular}{cccc}
\hline Discriminação & Receita Prevista & $\begin{array}{c}\text { Receita Arrecadada } \\
\text { Líquida }\end{array}$ & $\begin{array}{c}\text { Percentual de } \\
\text { arrecadação }\end{array}$ \\
\hline $\begin{array}{c}\text { RECEITA } \\
\text { TOTAL }\end{array}$ & $\mathbf{1 . 7 6 6 . 0 2 1 . 7 9 4 . 3 5 2 , 0 0}$ & $\mathbf{1 . 4 8 2 . 7 2 8 . 5 7 1 . 5 4 3 , 4 8}$ & $\mathbf{8 4 \%}$ \\
$\begin{array}{c}\text { RECEITA } \\
\text { ADMINISTRADA }\end{array}$ & $561.533 .077 .474,00$ & $523.167 .803 .311,93$ & $93 \%$ \\
$\begin{array}{c}\text { ARRECADAÇÃO } \\
\text { LÍQUIDA INSS }\end{array}$ & $202.139 .400 .670,00$ & $211.267 .367 .490,76$ & $105 \%$ \\
RECEITAS NÃO & $98.329 .225 .036,00$ & $96.918 .654 .673,18$ & $99 \%$ \\
ADMINISTRADAS & & & \\
RECEITA & $874.669 .625 .606,00$ & $618.984 .055 .987,95$ & $71 \%$ \\
FINANCEIRA & $29.350 .465 .566,00$ & $32.390 .690 .079,67$ & $110 \%$ \\
NÃO INFORMADO & &
\end{tabular}

Fonte: Portal Siga Brasil - Link: Execução Orçamentária - Subitem: Receita - Planilha: Execução da Receita 2010 (adaptada pelo autor).

\footnotetext{
${ }^{215}$ Esse efeito no Ministério do Desenvolvimento Social e Combate à Fome ocorreu muito provavelmente em razão da ressalva feita na Lei de Diretrizes Orçamentárias para 2010 (Lei no 12.017/2009). Foram excluídas do contingenciamento pelo item II (Demais despesas ressalvadas) do Anexo V (Despesas que não serão objeto de limitação de empenho, nos termos do artigo $9^{\circ}$, $\S 2^{\circ}$ da LRF). Algumas despesas do Ministério da Ciência e Tecnologia também foram ressalvadas pela LDO 2010, o que certamente contribuiu para que o percentual liquidado fosse de 94\%. Vide anexo $\mathrm{V}$ em http://www.camara.gov.br/internet/comissao/index/mista/orca/ldo/ldo2010/Lei12017/ANL12017-09-

Anexo\%20IV.6-VII.pdf. (Acesso em 28/05/2014). Essas ressalvas que pode ser feitas pela Lei de Diretrizes Orçamentárias reforçam a hipótese de que, através delas, cria-se um "sub-orçamento", com possibilidade de execução bem maior que as demais despesas.
} 
Ressalva-se que a comparação não é em termos absolutos, mas, de qualquer modo, se a expectativa de arrecadação chegou a $84 \%$ do previsto, é bastante criticável o planejamento das despesas discricionárias, cuja execução fica próxima a 50\%, sendo que alguns Ministérios executaram apenas $20 \%$ do orçamento inicialmente previsto. Esse comportamento se repetirá nos anos seguintes.

\subsubsection{Exercício de 2011}

No exercício de 2011, a programação financeira e os limites para empenho (contingenciamento) foram determinados inicialmente pelo Decreto $\mathrm{n}^{\mathrm{o}} 7.425$, de 05 de janeiro de 2011. Em verdade, naquele momento o orçamento do ano em questão não havia sido aprovado. Por isso que, em seu artigo $1^{\circ}$, dispõe o decreto que "até a publicação da Lei Orçamentária de 2011, e nos termos do art. 68 da Lei n ${ }^{\circ}$ 12.309, de 9 de agosto de 2010 [Lei de Diretrizes Orçamentárias], os órgãos, os fundos e as entidades do Poder Executivo que integram os Orçamentos Fiscal e da Seguridade Social da União somente poderão empenhar as dotações orçamentárias destinadas ao atendimento de (...)". Já no primeiro decreto e ainda sem o orçamento aprovado, o Anexo I trouxe os limites dos valores a serem empenhados.

O orçamento de 2011 foi aprovado pela Lei $\mathrm{n}^{\circ}$ 12.381, de 09 de fevereiro de 2011. Assim, foi o Decreto $\mathrm{n}^{\mathrm{o}} 7.445$, de 01 de março de 2011 que passou a estabelecer a programação orçamentária e financeira. Como de costume, em seu Anexo I, foram trazidos os limites de movimentação e empenho. Os valores se mantiveram até o último bimestre do exercício de 2011, tendo sido alterado somente em 22 de novembro de 2011, pela edição do Decreto $n^{\circ} 7.662 / 11$. Ao longo do exercício financeiro, vários decretos foram editados com alterações de metas e receitas, porém, os valores totais do Anexo I do primeiro Decreto, que consolida os "limites de movimentação e empenho" só foram alterados pelo Decreto $\mathrm{n}^{\mathbf{0}}$ 7.662/11. Por isso, para verificar os efeitos do contingenciamento, utilizam-se os dados do Anexo I do Decreto $\mathrm{n}^{\circ}$ 7.445/11, fixados originalmente, e depois alterados pelo Decerto $\mathrm{n}^{\circ}$ 7.662/11. Com dados da coluna "demais despesas" (despesas não obrigatórias), elabora-se a primeira tabela: 
Tabela 5. Dados comparativos entre os Decretos de Contingenciamento editados no exercício de 2011, contendo, por órgão, (i) as despesas não obrigatórias ("outras despesas") fixadas na Lei Orçamentária (acrescida de créditos adicionais), (ii) as despesas não obrigatórias ("outras despesas") disponíveis, conforme limites de empenho e movimentação financeira, e (iii) o percentual de disponibilidade das despesas não obrigatórias ("outras despesas") em relação ao fixado em lei.

\begin{tabular}{|c|c|c|c|c|c|c|}
\hline \multirow[b]{2}{*}{ Órgão } & \multicolumn{3}{|c|}{ Decreto 7.455 (Março/2011) } & \multicolumn{3}{|c|}{ Decreto 7.622 (Novembro/2011) } \\
\hline & $\begin{array}{l}\text { Despesa em } \\
\text { Lei }\end{array}$ & $\begin{array}{c}\text { Despesa } \\
\text { Disponível }\end{array}$ & $\begin{array}{c}\% \\
\text { Disponível }\end{array}$ & $\begin{array}{l}\text { Despesa em } \\
\text { Lei }\end{array}$ & $\begin{array}{c}\text { Despesa } \\
\text { Disponível }\end{array}$ & \% Disponível \\
\hline $\begin{array}{l}\text { PRESIDENCIA DA } \\
\text { REPUBLICA }\end{array}$ & 3.226 .030 & 2.544 .314 & $79 \%$ & 3.550 .819 & 2.627 .815 & $74 \%$ \\
\hline $\begin{array}{l}\text { VICE-PRESIDÊNCIA } \\
\text { DA REPÚBLICA }\end{array}$ & 3.500 & 3.223 & $92 \%$ & 3.500 & 3.498 & $100 \%$ \\
\hline $\begin{array}{l}\text { ADVOCACIA GERAL } \\
\text { DA UNIÂO }\end{array}$ & 269.083 & 228.000 & $85 \%$ & 269.083 & 248.000 & $92 \%$ \\
\hline $\begin{array}{l}\text { MINISTERIO DA } \\
\text { AGRICULTURA, } \\
\text { PECUARIA E } \\
\text { ABASTECIMENTO }\end{array}$ & 2.666 .865 & 1.198 .713 & $45 \%$ & 2.666 .865 & 1.492 .773 & $56 \%$ \\
\hline $\begin{array}{l}\text { MINISTERIO DA } \\
\text { CIENCIA E } \\
\text { TECNOLOGIA }\end{array}$ & 5.675 .484 & 4.721 .885 & $83 \%$ & 5.674 .339 & 4.770 .735 & $84 \%$ \\
\hline $\begin{array}{l}\text { MINISTERIO DA } \\
\text { FAZENDA }\end{array}$ & 3.443 .252 & 2.640 .000 & $77 \%$ & 3.443 .252 & 3.400 .137 & $99 \%$ \\
\hline $\begin{array}{l}\text { MINISTERIO DA } \\
\text { EDUCACAO }\end{array}$ & 21.299 .484 & 18.197 .590 & $85 \%$ & 21.881 .834 & 18.222 .652 & $83 \%$ \\
\hline $\begin{array}{l}\text { MINISTERIO DO } \\
\text { DESENVOLVIMENTO, } \\
\text { INDÚSTRIA E } \\
\text { COMERCIO } \\
\text { EXTERIOR }\end{array}$ & 827.891 & 622.493 & $75 \%$ & 898.608 & 776.293 & $86 \%$ \\
\hline $\begin{array}{l}\text { MINISTERIO DA } \\
\text { JUSTICA }\end{array}$ & 4.500 .667 & 2.974 .300 & $66 \%$ & 4.749 .118 & 3.193 .426 & $67 \%$ \\
\hline $\begin{array}{l}\text { MINISTERIO DE } \\
\text { MINAS E ENERGIA }\end{array}$ & 938.702 & 701.831 & $75 \%$ & 968.041 & 719.831 & $74 \%$ \\
\hline $\begin{array}{c}\text { MINISTERIO DA } \\
\text { PREVIDENCIA } \\
\text { SOCIAL }\end{array}$ & 1.855 .286 & 1.500 .000 & $81 \%$ & 1.885 .286 & 1.732 .000 & $92 \%$ \\
\hline $\begin{array}{c}\text { MINISTERIO DAS } \\
\text { RELACOES } \\
\text { EXTERIORES }\end{array}$ & 1.151 .332 & 876.000 & $76 \%$ & 1.151 .332 & 892.150 & $77 \%$ \\
\hline $\begin{array}{l}\text { MINISTERIO DA } \\
\text { SAUDE }\end{array}$ & 12.782 .795 & 12.204 .092 & $95 \%$ & 13.454 .959 & 12.720 .002 & $95 \%$ \\
\hline $\begin{array}{l}\text { MINISTERIO DO } \\
\text { TRABALHO E } \\
\text { EMPREGO }\end{array}$ & 1.395 .860 & 900.000 & $64 \%$ & 1.395 .860 & 980.720 & $70 \%$ \\
\hline $\begin{array}{l}\text { MINISTERIO DOS } \\
\text { TRANSPORTES }\end{array}$ & 18.209 .860 & 15.816 .414 & $87 \%$ & 18.506 .443 & 15.916 .415 & $86 \%$ \\
\hline $\begin{array}{l}\text { MINISTERIO DAS } \\
\text { COMUNICACOES }\end{array}$ & 1.028 .203 & 425.000 & $41 \%$ & 1.049 .500 & 469.000 & $45 \%$ \\
\hline $\begin{array}{l}\text { MINISTERIO DA } \\
\text { CULTURA }\end{array}$ & 1.307 .376 & 778.006 & $60 \%$ & 1.537 .814 & 1.035 .856 & $67 \%$ \\
\hline $\begin{array}{l}\text { MINISTERIO DO } \\
\text { MEIO AMBIENTE }\end{array}$ & 1.031 .882 & 633.727 & $61 \%$ & 982.900 & 748.980 & $76 \%$ \\
\hline
\end{tabular}




\begin{tabular}{|c|c|c|c|c|c|c|}
\hline $\begin{array}{l}\text { MINISTERIO DO } \\
\text { PLANEJAMENTO, } \\
\text { ORCAMENTO E } \\
\text { GESTAO }\end{array}$ & 962.924 & 775.550 & $81 \%$ & 714.347 & 700.029 & $\mathbf{9 8 \%}$ \\
\hline $\begin{array}{c}\text { MINISTERIO DO } \\
\text { DESENVOLVIMENTO } \\
\text { AGRARIO }\end{array}$ & 3.087 .777 & 2.158 .402 & $70 \%$ & 3.104 .297 & 2.649 .515 & $85 \%$ \\
\hline $\begin{array}{l}\text { MINISTERIO DO } \\
\text { ESPORTE }\end{array}$ & 2.371 .508 & 850.000 & $36 \%$ & 2.732 .796 & 1.026 .355 & $38 \%$ \\
\hline $\begin{array}{l}\text { MINISTERIO DA } \\
\text { DEFESA }\end{array}$ & 13.113.315 & 8.730 .163 & $67 \%$ & 12.875 .404 & 11.114 .195 & $86 \%$ \\
\hline $\begin{array}{l}\text { MINISTERIO DA } \\
\text { INTEGRACAO } \\
\text { NACIONAL }\end{array}$ & 4.610 .180 & 2.793 .271 & $61 \%$ & 4.787 .478 & 3.217 .238 & $67 \%$ \\
\hline $\begin{array}{l}\text { MINISTERIO DO } \\
\text { TURISMO }\end{array}$ & 3.652 .438 & 570.000 & $16 \%$ & 3.652 .438 & 896.646 & $25 \%$ \\
\hline $\begin{array}{c}\text { MINISTERIO DO } \\
\text { DESENVOLVIMENTO } \\
\text { SOCIAL E COMBATE } \\
\text { À FOME }\end{array}$ & 4.051 .907 & 4.029 .056 & $99 \%$ & 3.482 .759 & 3.433 .986 & $99 \%$ \\
\hline $\begin{array}{l}\text { MINISTERIO DAS } \\
\text { CIDADES }\end{array}$ & 21.076.261 & 12.498 .812 & $59 \%$ & 21.080 .061 & 14.849 .199 & $70 \%$ \\
\hline $\begin{array}{l}\text { MINISTERIO DA } \\
\text { PESCA E } \\
\text { AQÜICULTURA }\end{array}$ & 524.837 & 214.000 & $41 \%$ & 524.837 & 218.298 & $42 \%$ \\
\hline $\begin{array}{c}\text { ENCARGOS } \\
\text { FINANCEIROS DA } \\
\text { UNIAO }\end{array}$ & 1.360 .426 & 672.511 & $49 \%$ & 1.360 .426 & 662.374 & $49 \%$ \\
\hline $\begin{array}{l}\text { TRANSFERENCIAS A } \\
\text { ESTADOS, DISTRITO } \\
\text { FEDERAL E } \\
\text { MUNICIPIOS }\end{array}$ & 41.350 & 8.000 & $19 \%$ & 41.350 & 8.000 & $19 \%$ \\
\hline TOTAL OFICIAL & 136.608 .759 & 100.407 .638 & $74 \%$ & 138.571 .403 & 108.868 .401 & $79 \%$ \\
\hline
\end{tabular}

Fonte: Anexo I do Decreto $n^{\circ} 7.455 / 2011$, alterado pelo Decreto $\mathrm{n}^{\circ}$ 7.622/2011 (foram considerados apenas os Decretos que alteraram a limitação de empenho e movimentação financeira) (elaborada pelo autor).

Analisando o contingenciamento do ano-calendário de 2011, necessário notar que o percentual de despesas disponíveis aumentou desde o primeiro para o último decreto de contingenciamento. $\mathrm{O}$ valor total disponibilizado para empenho, considerando todos os órgãos foi de $74 \%$ no primeiro contingenciamento e de $79 \%$ no segundo. Ainda, em grande parte dos órgãos, novamente o percentual disponível, seja no primeiro seja no segundo decreto de contingenciamento corresponde a um percentual muito abaixo do total de despesas aprovadas (com atualizações). Novamente há exemplos de extrema gravidade, como o Ministério do Turismo, para o qual foi inicialmente disponibilizado somente $16 \%$ e, ao final do exercício, apenas 25\%; bem como o do Ministério das Comunicações, com apenas $45 \%$, dentre outros.

Em termos totais, o decreto inicialmente contingenciou 36 bilhões em março e depois 29 bilhões em novembro. O primeio contingenciamento seguiu o indicado pelo Relatório Bimestral. Porém, o último Relatório ( $5^{\circ}$ Bimestre) apontou a necessidade de 
contingenciamento em 24 bilhões, abaixo do que foi determinado no decreto editado em novembro (29 bilhões). Verifica-se a evolução dos Relatórios na tabela abaixo:

Tabela 6. Evolução (ampliação ou redução) dos limites de empenho e movimentação financeira indicados para o Executivo pelo Relatório de Avaliação Bimestral em 2011. Em milhões.

\begin{tabular}{|c|c|c|c|c|c|c|}
\hline & $\begin{array}{c}\text { Decreto de } \\
\text { Programaçã } \\
\text { o (Fev/2011) }\end{array}$ & $1^{0}$ Bimestre & $2^{\circ}$ Bimestre & $3^{0}$ Bimestre & $4^{\circ}$ Bimestre & $5^{\circ}$ Bimestre \\
\hline $\begin{array}{c}\text { Ampliação/Redução } \\
\text { sugerido para a } \\
\text { limitação de } \\
\text { empenho e } \\
\text { movimentação } \\
\text { financeira do } \\
\text { Executivo }\end{array}$ & $\begin{array}{c}\mathrm{R} \$ \\
36.000,20\end{array}$ & $\mathrm{R} \$ 0,00$ & $\mathrm{R} \$ 0,00$ & $\mathrm{R} \$ 0,00$ & $-\mathrm{R} \$ 10,00$ & $-\mathrm{R} \$ 11.963,00$ \\
\hline $\begin{array}{l}\text { Total da Limitação } \\
\text { (soma da } \\
\text { ampliação/redução } \\
\text { do bimestre atual } \\
\text { com o totalizado do } \\
\text { bimestre anterior) }\end{array}$ & $\begin{array}{c}\mathrm{R} \$ \\
36.000,20\end{array}$ & $\mathrm{R} \$ 36.000,20$ & $\mathrm{R} \$ 36.000,20$ & $\mathrm{R} \$ 36.000,20$ & $\mathrm{R} \$ 35.990,20$ & $\mathrm{R} \$ 24.027,20$ \\
\hline
\end{tabular}

Fonte: Relatórios de Avaliação Bimestral do exercício de 2011 (elaborado pelo autor).

Mais uma vez, há uma distorção entre o efetivamente contingenciado e o que foi determinado no Relatório. O que se repete com ainda mais nitidez é que o baixo percentual de recursos disponibilizados para as despesas não obrigatórias reflete na execução ads despesas discricionárias, conforme se verifica:

Tabela 7. Dados da Execução Orçamentária das despesas discricionárias em 2011, contendo, por órgão, (i) percentual executado (metodologia do Siga Brasil); (ii) \% empenhado/liquidado (em relação ao autorizado); (iii) percentual pago em relação ao empenhado/liquidado; e (iv) percentual pago em relação ao autorizado

\begin{tabular}{ccccc}
\hline Órgão (Cod/Desc) & $\begin{array}{c}\% \\
\text { Executado }\end{array}$ & $\begin{array}{c}\% \\
\text { Liquidado }\end{array}$ & $\begin{array}{c}\text { \% Pago (sobre } \\
\text { liquidado) }\end{array}$ & $\begin{array}{c}\text { \% Pago (sobre } \\
\text { autorizado) }\end{array}$ \\
\hline PRESIDENCIA DA REPUBLICA & $53,1 \%$ & $70,1 \%$ & $62,8 \%$ & $45,6 \%$ \\
PRESIDENCIA DA REPUBLICA & $45,6 \%$ & $56,5 \%$ & $80,6 \%$ & $31,8 \%$ \\
$\begin{array}{c}\text { MINISTERIO DA } \\
\text { AGRICULTURA, PECUARIA E } \\
\text { ABASTECIMENTO }\end{array}$ & $38,1 \%$ & $64,5 \%$ & $49,3 \%$ & $50,8 \%$ \\
$\begin{array}{c}\text { MINISTERIO DA CIENCIA E } \\
\text { TECNOLOGIA }\end{array}$ & $53,4 \%$ & $85,9 \%$ & $59,1 \%$ & $67,8 \%$ \\
MINISTERIO DA FAZENDA & $70,3 \%$ & $87,8 \%$ & $77,2 \%$ & $59,4 \%$ \\
MINISTERIO DA EDUCACAO & $62,1 \%$ & $87,0 \%$ & $68,3 \%$ & $72,3 \%$
\end{tabular}




\begin{tabular}{|c|c|c|c|c|}
\hline $\begin{array}{c}\text { MINISTERIO DO } \\
\text { DESENVOLVIMENTO, } \\
\text { INDÚSTRIA E COMERCIO } \\
\text { EXTERIOR }\end{array}$ & $70,1 \%$ & $79,2 \%$ & $91,2 \%$ & $38,0 \%$ \\
\hline MINISTERIO DA JUSTICA & $42,7 \%$ & $54,5 \%$ & $69,7 \%$ & $20,3 \%$ \\
\hline $\begin{array}{l}\text { MINISTERIO DE MINAS E } \\
\text { ENERGIA }\end{array}$ & $25,8 \%$ & $28,0 \%$ & $72,7 \%$ & $74,6 \%$ \\
\hline $\begin{array}{l}\text { MINISTERIO DA PREVIDENCIA } \\
\text { SOCIAL }\end{array}$ & $75,0 \%$ & $88,4 \%$ & $84,3 \%$ & $69,8 \%$ \\
\hline $\begin{array}{l}\text { MINISTERIO DAS RELACOES } \\
\text { EXTERIORES }\end{array}$ & $70,2 \%$ & $71,3 \%$ & $97,8 \%$ & $84,2 \%$ \\
\hline MINISTERIO DA SAUDE & $79,3 \%$ & $96,9 \%$ & $86,9 \%$ & $33,1 \%$ \\
\hline $\begin{array}{l}\text { MINISTERIO DO TRABALHO E } \\
\text { EMPREGO }\end{array}$ & $42,0 \%$ & $63,0 \%$ & $52,5 \%$ & $36,1 \%$ \\
\hline $\begin{array}{l}\text { MINISTERIO DOS } \\
\text { TRANSPORTES }\end{array}$ & $47,1 \%$ & $79,4 \%$ & $45,4 \%$ & $28,1 \%$ \\
\hline $\begin{array}{l}\text { MINISTERIO DAS } \\
\text { COMUNICACOES }\end{array}$ & $33,7 \%$ & $44,1 \%$ & $63,6 \%$ & $21,5 \%$ \\
\hline MINISTERIO DA CULTURA & $31,1 \%$ & $68,0 \%$ & $31,7 \%$ & $30,5 \%$ \\
\hline $\begin{array}{l}\text { MINISTERIO DO MEIO } \\
\text { AMBIENTE }\end{array}$ & $32,4 \%$ & $39,4 \%$ & $77,4 \%$ & $54,6 \%$ \\
\hline $\begin{array}{c}47000 \text { - MINISTERIO DO } \\
\text { PLANEJAMENTO, ORCAMENTO } \\
\text { E GESTAO }\end{array}$ & $65,8 \%$ & $78,5 \%$ & $69,6 \%$ & $37,4 \%$ \\
\hline $\begin{array}{c}\text { MINISTERIO DO } \\
\text { DESENVOLVIMENTO AGRARIO }\end{array}$ & $43,9 \%$ & $70,7 \%$ & $52,9 \%$ & $10,3 \%$ \\
\hline MINISTERIO DO ESPORTE & $17,8 \%$ & $41,0 \%$ & $25,1 \%$ & $59,0 \%$ \\
\hline MINISTERIO DA DEFESA & $63,1 \%$ & $87,9 \%$ & $67,2 \%$ & $21,1 \%$ \\
\hline $\begin{array}{l}\text { MINISTERIO DA INTEGRACAO } \\
\text { NACIONAL }\end{array}$ & $32,4 \%$ & $58,0 \%$ & $36,3 \%$ & $5,3 \%$ \\
\hline MINISTERIO DO TURISMO & $14,7 \%$ & $34,1 \%$ & $15,5 \%$ & $95,7 \%$ \\
\hline $\begin{array}{c}\text { MINISTERIO DO } \\
\text { DESENVOLVIMENTO SOCIAL E } \\
\text { COMBATE À FOME }\end{array}$ & $94,6 \%$ & $98,1 \%$ & $97,5 \%$ & $8,3 \%$ \\
\hline MINISTERIO DAS CIDADES & $17,8 \%$ & $77,2 \%$ & $10,7 \%$ & $14,6 \%$ \\
\hline $\begin{array}{l}\text { MINISTERIO DA PESCA E } \\
\text { AQÜICULTURA }\end{array}$ & $15,0 \%$ & $33,0 \%$ & $44,3 \%$ & $0,0 \%$ \\
\hline $\begin{array}{l}\text { ENCARGOS FINANCEIROS DA } \\
\text { UNIAO }\end{array}$ & $22,8 \%$ & $43,9 \%$ & $80,0 \%$ & $64,5 \%$ \\
\hline $\begin{array}{l}\text { TRANSFERENCIAS A ESTADOS, } \\
\text { DISTRITO FEDERAL E } \\
\text { MUNICIPIOS }\end{array}$ & $84,7 \%$ & $64,8 \%$ & $99,5 \%$ & $1,3 \%$ \\
\hline $\begin{array}{l}\text { OPERACOES OFICIAIS DE } \\
\text { CREDITO }\end{array}$ & $4,4 \%$ & $87,3 \%$ & $1,5 \%$ & $57,7 \%$ \\
\hline TOTAL & $56,8 \%$ & $83,4 \%$ & $69,1 \%$ & $57,7 \%$ \\
\hline
\end{tabular}

Fonte: Portal Siga Brasil - Link: Execução Orçamentária - Subitem: Programação Financeira/ Contingenciamento - Planilha: "Despesa Discricionária Executivo - Fiscal e Seguridade - 2011”. (adaptada pelo autor).

A execução orçamentária ficou mais uma vez bastante prejudicada se comparada com os valores aprovados inicialmente, especialmente levando em conta o percentual executado conforme critérios do próprio Siga Brasil. Destaca-se, ainda, que o problema se 
encontra por vezes no baixo percentual de empenho, como se verifica nos casos do Ministério de Minas e Energia (28\%), Ministério do Meio Ambiente (39\%), Ministério da Pesca e Aquicultura (33\%); por vezes no baixo percentual de pagamento em relação às despesas já liquidadas, exemplos do Ministério dos Transportes (45\%), Ministério da Cultura (32\%), Ministério do Esporte (25\%), Ministério do Turismo (15\%), Ministério das Cidades (11\%). Constata-se que são raros os exemplos de órgão que tiveram o percentual executado acima de 75\%: Conselho Nacional de Justiça (91,6\%), Ministério da Previdência Social (75,05\%), Ministério da Saúde (79,28\%) e Ministério do Desenvolvimento Social e Combate à fome (94,63\%). Os exemplos ilustram que o quadro geral é preocupante quanto às despesas discricionárias no orçamento.

Por fim, quanto à realização de receitas, verifica-se que não houve problemas tão graves. A arrecadação total, em relação àquilo que foi previsto, ficou em torno de $87 \%$, conforme demonstra abaixo:

Tabela 8. Execução de Receitas do exercício de 2011, indicando, por tipo, (i) a receita prevista, (ii) a receita arrecadada, e (iii) o percentual arrecadado em relação ao previsto.

\begin{tabular}{cccc}
\hline Discriminação & Receita Prevista & $\begin{array}{c}\text { Receita Arrecadada } \\
\text { Líquida }\end{array}$ & $\begin{array}{c}\text { Percentual de } \\
\text { Arrecadação }\end{array}$ \\
\hline RECEITA TOTAL & $\mathbf{1 . 9 6 6 . 0 1 5 . 8 9 6 . 2 1 1}$ & $\mathbf{1 . 7 0 0 . 9 9 6 . 8 8 0 . 0 4 5}$ & $\mathbf{8 7 \%}$ \\
RECEITA & & 616.037 .016 .693 & $96 \%$ \\
ADMINISTRADA & 642.458 .766 .015 & 245.227 .992 .030 & $102 \%$ \\
$\begin{array}{c}\text { ARRECADAÇÃO } \\
\text { LÍQUIDA INSS }\end{array}$ & 239.787 .439 .926 & 115.647 .851 .812 & $107 \%$ \\
$\begin{array}{c}\text { RECEITAS NÃO } \\
\text { ADMINISTRADAS } \\
\text { RECEITA }\end{array}$ & 107.806 .107 .946 & 724.084 .019 .510 & $76 \%$ \\
$\begin{array}{c}\text { FINANCEIRA } \\
\text { NÃO INFORMADO }\end{array}$ & 949.969 .152 .649 & 0 & $0 \%$ \\
\hline
\end{tabular}

Fonte: Portal Siga Brasil - Link: Execução Orçamentária - Subitem: Receita - Planilha: Execução da Receita 2011 (adaptada pelo autor).

Comparando os anos de 2010 e 2011, nota-se que a arrecadação foi mais próxima do previsto em 2011 do que em 2010 (87\% em oposição a 84\%). No entanto, o percentual de execução foi um pouco menor em 2011 do que em 2010, o que denota uma desvinculação entre a expectativa de arrecadação e a expectativa de execução.

O excesso contingenciado no ano de 2011, sem relação com a frustração de receitas, foi objeto de crítica por Vander Gontijo, especialmente quanto às justificativas do Decreto no 7.445, de 01/03/2011, acima mencionado: “Convenientemente a Presidente da 
República não citou o artigo $9^{\circ}$ da LRF como base para o contingenciamento decretado (...) ao arrepio da LRF, introduziu na literatura nacional a figura da `reprogramação orçamentária, 216 .

O comportamento verificado nos anos de 2010 e 2011 segue nos anos seguintes.

\subsubsection{Exercício de 2012}

No exercício de 2012, o Poder Executivo editou o primeiro decreto de contingenciamento em 17 fevereiro de 2012 - Decreto $n^{\circ}$ 7.680/12. Como usualmente ocorre, foi efetuado o contingenciamento através do "Anexo I - limites de movimentação e empenho". Durante o ano, outros quatro decretos de programação financeira foram editados, porém, nenhum deles alterou o contingenciamento previsto no Anexo I do Decreto $\mathrm{n}^{\mathrm{o}}$ 7.680, de 17 de fevereiro de 2012. Abaixo os percentuais de disponibilidade, lembrando-se que a tabela contempla os valores de "outras despesas" (não obrigatórias) referentes ao único contingenciamento do ano.

Tabela 9. Dados comparativos entre os Decretos de Contingenciamento editados no exercício de 2012, contendo, por órgão, (i) as despesas não obrigatórias ("outras despesas") fixadas na Lei Orçamentária (acrescida de créditos adicionais), (ii) as despesas não obrigatórias (“outras despesas”) disponíveis, conforme limites de empenho e movimentação financeira, e (iii) o percentual de disponibilidade das despesas não obrigatórias ("outras despesas") em relação ao fixado em lei.

\begin{tabular}{|c|c|c|c|}
\hline \multirow[b]{3}{*}{ Órgão } & \multirow{2}{*}{\multicolumn{3}{|c|}{ Decreto 7.680 (fevereiro/2012) }} \\
\hline & & & \\
\hline & Despesa em Lei & Despesa Disponível & $\begin{array}{c}\% \\
\text { Disponível }\end{array}$ \\
\hline PRESIDENCIA DA REPUBLICA & 2.991.318.747 & 2.475 .009 .702 & $83 \%$ \\
\hline VICE-PRESIDÊNCIA DA REPÚBLICA & 5.023 .000 & 5.023 .000 & $100 \%$ \\
\hline ADVOCACIA GERAL DA UNIÂO & 251.896 .866 & 242.615 .406 & $96 \%$ \\
\hline $\begin{array}{l}\text { MINISTERIO DA AGRICULTURA, } \\
\text { PECUARIA E ABASTECIMENTO }\end{array}$ & 3.157 .611 .176 & 1.199.162.986 & $38 \%$ \\
\hline $\begin{array}{l}\text { MINISTERIO DA CIENCIA E } \\
\text { TECNOLOGIA }\end{array}$ & 6.631 .132 .256 & 5.144 .841 .964 & $78 \%$ \\
\hline MINISTERIO DA FAZENDA & 3.367 .242 .502 & 2.640 .257 .785 & $78 \%$ \\
\hline MINISTERIO DA EDUCACAO & 27.273.293.819 & 25.335.402.669 & $93 \%$ \\
\hline $\begin{array}{l}\text { MINISTERIO DO DESENVOLVIMENTO, } \\
\text { INDÚSTRIA E COMERCIO EXTERIOR }\end{array}$ & 1.264 .830 .385 & 702.867 .690 & $56 \%$ \\
\hline
\end{tabular}

${ }^{216}$ GONTIJO, Vander. Orçamento impositivo, contingenciamento e transparência. In: Cadernos Aslegis, n.39, p. 61-72, jan/abr 2010, p. 67. 


\begin{tabular}{|c|c|c|c|}
\hline MINISTERIO DA JUSTICA & 5.098 .352 .187 & 2.851 .064 .858 & $56 \%$ \\
\hline MINISTERIO DE MINAS E ENERGIA & 991.044 .080 & 772.447 .278 & $78 \%$ \\
\hline $\begin{array}{l}\text { MINISTERIO DA PREVIDENCIA } \\
\text { SOCIAL }\end{array}$ & 1.992 .350 .000 & 1.499 .531 .032 & $75 \%$ \\
\hline $\begin{array}{l}\text { MINISTERIO DAS RELACOES } \\
\text { EXTERIORES }\end{array}$ & 967.251 .755 & 1.118 .524 .710 & $116 \%$ \\
\hline MINISTERIO DA SAUDE & 20.346 .275 .013 & 14.873 .717 .283 & $73 \%$ \\
\hline $\begin{array}{l}\text { MINISTERIO DO TRABALHO E } \\
\text { EMPREGO }\end{array}$ & 1.179 .586 .460 & 900.493 .364 & $76 \%$ \\
\hline MINISTERIO DOS TRANSPORTES & 18.825 .924 .443 & 16.849 .839 .451 & $90 \%$ \\
\hline MINISTERIO DAS COMUNICACOES & 795.670 .461 & 450.468 .717 & $57 \%$ \\
\hline MINISTERIO DA CULTURA & 1.518.115.279 & 1.078 .030 .326 & $71 \%$ \\
\hline MINISTERIO DO MEIO AMBIENTE & 962.293 .064 & 765.172 .169 & $80 \%$ \\
\hline $\begin{array}{l}\text { MINISTERIO DO PLANEJAMENTO, } \\
\text { ORCAMENTO E GESTAO }\end{array}$ & 675.212 .251 & 555.022 .320 & $82 \%$ \\
\hline $\begin{array}{l}\text { MINISTERIO DO DESENVOLVIMENTO } \\
\text { AGRARIO }\end{array}$ & 3.460 .925 .087 & 2.266 .673 .680 & $65 \%$ \\
\hline MINISTERIO DO ESPORTE & 2.471 .817 .061 & 669.777 .999 & $27 \%$ \\
\hline MINISTERIO DA DEFESA & 13.699 .444 .621 & 10.380 .397 .879 & $76 \%$ \\
\hline $\begin{array}{l}\text { MINISTERIO DA INTEGRACAO } \\
\text { NACIONAL }\end{array}$ & 6.606 .200 .364 & 4.412 .824 .327 & $67 \%$ \\
\hline MINISTERIO DO TURISMO & 2.609.628.177 & 599.717 .579 & $23 \%$ \\
\hline $\begin{array}{l}\text { MINISTERIO DO DESENVOLVIMENTO } \\
\text { SOCIAL E COMBATE À FOME }\end{array}$ & 5.888 .997 .415 & 4.957.812.777 & $84 \%$ \\
\hline MINISTERIO DAS CIDADES & 20.741.307.572 & 17.419.057.643 & $84 \%$ \\
\hline $\begin{array}{l}\text { MINISTERIO DA PESCA E } \\
\text { AQÜICULTURA }\end{array}$ & 290.019 .217 & 213.725 .400 & $74 \%$ \\
\hline ENCARGOS FINANCEIROS DA UNIAO & 1.967 .282 .360 & 663.383 .716 & $34 \%$ \\
\hline $\begin{array}{l}\text { TRANSFERENCIAS A ESTADOS, } \\
\text { DISTRITO FEDERAL E MUNICIPIOS }\end{array}$ & 34.497 .130 & 12.500 .000 & $36 \%$ \\
\hline TOTAL OFICIAL & 156.203 .795 .865 & 121.193.816.710 & $78 \%$ \\
\hline
\end{tabular}

Fonte: Anexo I do Decreto 7.680/2012 (não houve alteração no Anexo I) (elaborada pelo autor).

No ano de 2011, tornou-se difícil a visualização dos contingenciamentos, já que apenas um decreto consolidou de forma explícita os montantes disponibilizados. Nos demais decretos veiculados durante o ano, não se pode notar alterações no Anexo I, o que, inclusive, dificulta a análise. De qualquer modo, os altos percentuais de contingenciamento se repetem em diversos órgãos. Interessante notar, ainda, que a rubrica da vice-presidencia teve $100 \%$ disponibilizado e a do Ministério das Relações Exteriores $116 \%$. A tabela não explica como foi possível disponibilizar mais do que o aprovado em orçamento. Presume- 
se que ou havia uma expectativa de abertura de créditos adicionais ou então um remanejamento, operações criticáveis em termos de planejamento e especialmente diante do quadro que se observa nos demais órgãos.

Veja-se que o contingenciamento total, de 35 bilhões acompanhou o que determinado pelo Relatório de Avaliação do $1^{\mathrm{o}}$ Bimestre. Porém, tendo em vista a indicação dos Relatórios do $2^{\circ}$ e $5^{\circ}$ Bimestre, os decretos que se seguiram deveriam ter modificado tal limite, alterando expressamente o Anexo I, o que não ocorreu, razão pela qual, ao menos explicitamente, não é possível verificar os descontingenciamentos por órgão. Veja-se a tabela abaixo, indicando a evolução de contingenciamento proposta pelos Relatórios de Avaliação de 2012:

Tabela 10. Evolução (ampliação ou redução) dos limites de empenho e movimentação financeira indicados para o Executivo pelo Relatório de Avaliação Bimestral em 2012.

\begin{tabular}{|c|c|c|c|c|c|}
\hline & $1^{\circ}$ Bimestre & $2^{\circ}$ Bimestre & $3^{\circ}$ Bimestre & $4^{\circ}$ Bimestre & $5^{\circ}$ Bimestre \\
\hline $\begin{array}{c}\text { Ampliação/Redução } \\
\text { sugerido para a } \\
\text { Limitação de empenho e } \\
\text { movimentação } \\
\text { financeira do Executivo }\end{array}$ & $\mathrm{R} \$ 35.010$ & $-\mathrm{R} \$ 1.315$ & $\mathrm{R} \$ 0$ & $\mathrm{R} \$ 0$ & $-\mathrm{R} \$ 8.408$ \\
\hline $\begin{array}{c}\text { Total da Limitação } \\
\text { (soma da } \\
\text { ampliação/redução do } \\
\text { bimestre atual com o } \\
\text { totalizado do bimestre } \\
\text { anterior) }\end{array}$ & $\mathrm{R} \$ 35.010$ & $\mathrm{R} \$ 33.695$ & $\mathrm{R} \$ 33.695$ & $\mathrm{R} \$ 33.695$ & $\mathrm{R} \$ 25.287$ \\
\hline
\end{tabular}

Fonte: Relatórios de Avaliação Bimestral do exercício de 2012 (elaborado pelo autor).

No tocante aos percentuais de execução orçamentária, empenho e pagamento, a tabela referente ao ano de 2012 mostra um comportamento um pouco distinto, uma vez que o percentual de empenho/liquidação ficou ainda mais baixo que nos anos anteriores, porém, quase que a totalidade do que foi empenhado/liquidado foi pago (98\%). Deixou-se, portanto, uma quantidade menor de restos a pagar relativos a despesas discricionárias, ao menos quando se comparam os períodos anteriores. Isso seria um bom indicativo de melhor planejamento. O passo seguinte seria equilibrar melhor os percentuais de empenho/liquidação.

De qualquer maneira, também no exercício de 2012, constata-se mais uma vez que vários órgãos seguem com uma inexecução orçamentária bastante significativa, já que o que foi pago permaneceu muito abaixo do que é aprovado para despesas discricionárias. Destaca-se, ainda, que alguns órgão estão subdivididos em dois, sendo os dados fornecidos 
de maneira distinta, o que dificulta a visualização, mas não impede perceber a baixa execução de despesas discricionárias.

Tabela 11. Dados da Execução Orçamentária das despesas discricionárias em 2012, contendo, por órgão, (i) percentual executado (metodologia do Siga Brasil); (ii) \% empenhado/liquidado (em relação ao autorizado); (iii) percentual pago em relação ao empenhado/liquidado; e (iv) percentual pago em relação ao autorizado

\begin{tabular}{|c|c|c|c|c|}
\hline Órgão (Cod/Desc) & $\begin{array}{c}\% \\
\text { Executado }\end{array}$ & $\begin{array}{c}\% \\
\text { Liquidado }\end{array}$ & $\begin{array}{l}\text { \% Pago (sobre } \\
\text { liquidado) }\end{array}$ & $\begin{array}{l}\text { \% Pago (sobre } \\
\text { autorizado) }\end{array}$ \\
\hline $\begin{array}{c}\text { CONSELHO NACIONAL } \\
\text { DE JUSTICA }\end{array}$ & $30,0 \%$ & $30,0 \%$ & $100,0 \%$ & $30,0 \%$ \\
\hline $\begin{array}{l}\text { PRESIDENCIA DA } \\
\text { REPUBLICA }\end{array}$ & $49,0 \%$ & $41,6 \%$ & $96,2 \%$ & $40,0 \%$ \\
\hline $\begin{array}{l}\text { PRESIDENCIA DA } \\
\text { REPUBLICA }\end{array}$ & $0,0 \%$ & $0,0 \%$ & 0 & $0,0 \%$ \\
\hline $\begin{array}{l}\text { ADVOCACIA-GERAL DA } \\
\text { UNIAO }\end{array}$ & $0,0 \%$ & $0,0 \%$ & 0 & $0,0 \%$ \\
\hline $\begin{array}{l}\text { MINISTERIO DA } \\
\text { AGRICULTURA, } \\
\text { PECUARIA E } \\
\text { ABASTECIMENTO }\end{array}$ & $31,2 \%$ & $30,0 \%$ & $80,5 \%$ & $24,1 \%$ \\
\hline $\begin{array}{l}\text { MINISTERIO DA CIENCIA } \\
\text { E TECNOLOGIA }\end{array}$ & $62,8 \%$ & $0,0 \%$ & $0,0 \%$ & $0,0 \%$ \\
\hline $\begin{array}{c}\text { MINISTERIO DA } \\
\text { CIENCIA, TECNOLOGIA E } \\
\text { INOVACAO }\end{array}$ & $45,1 \%$ & $51,0 \%$ & $88,4 \%$ & $45,1 \%$ \\
\hline $\begin{array}{l}\text { MINISTERIO DA } \\
\text { FAZENDA }\end{array}$ & $52,6 \%$ & $57,6 \%$ & $83,5 \%$ & $48,1 \%$ \\
\hline $\begin{array}{l}\text { MINISTERIO DA } \\
\text { EDUCACAO }\end{array}$ & $57,8 \%$ & $56,1 \%$ & $98,6 \%$ & $55,3 \%$ \\
\hline $\begin{array}{c}\text { MINISTERIO DO } \\
\text { DESENV.,IND. E } \\
\text { COMERCIO EXTERIOR }\end{array}$ & $66,7 \%$ & $67,2 \%$ & $99,4 \%$ & $66,7 \%$ \\
\hline $\begin{array}{l}\text { MINISTERIO DO } \\
\text { DESENVOLVIMENTO, } \\
\text { INDÚSTRIA E COMERCIO } \\
\text { EXTERIOR }\end{array}$ & $57,6 \%$ & $0,0 \%$ & $0,0 \%$ & $0,0 \%$ \\
\hline MINISTERIO DA JUSTICA & $35,4 \%$ & $30,2 \%$ & $99,5 \%$ & $30,0 \%$ \\
\hline $\begin{array}{l}\text { MINISTERIO DE MINAS E } \\
\text { ENERGIA }\end{array}$ & $44,6 \%$ & $39,9 \%$ & $93,5 \%$ & $37,3 \%$ \\
\hline $\begin{array}{c}\text { MINISTERIO DA } \\
\text { PREVIDENCIA SOCIAL }\end{array}$ & $76,6 \%$ & $89,5 \%$ & $85,7 \%$ & $76,6 \%$ \\
\hline $\begin{array}{c}\text { MINISTERIO DAS } \\
\text { RELACOES EXTERIORES }\end{array}$ & $89,7 \%$ & $89,7 \%$ & $100,0 \%$ & $89,6 \%$ \\
\hline MINISTERIO DA SAUDE & $74,8 \%$ & $78,4 \%$ & $99,6 \%$ & $78,2 \%$ \\
\hline $\begin{array}{c}\text { MINISTERIO DO } \\
\text { TRABALHO E EMPREGO }\end{array}$ & $45,1 \%$ & $36,4 \%$ & $96,3 \%$ & $35,1 \%$ \\
\hline $\begin{array}{l}\text { MINISTERIO DOS } \\
\text { TRANSPORTES }\end{array}$ & $35,0 \%$ & $21,9 \%$ & $99,3 \%$ & $21,7 \%$ \\
\hline $\begin{array}{l}\text { MINISTERIO DAS } \\
\text { COMUNICACOES }\end{array}$ & $26,0 \%$ & $22,7 \%$ & $82,8 \%$ & $18,8 \%$ \\
\hline $\begin{array}{l}\text { MINISTERIO DA } \\
\text { CULTURA }\end{array}$ & $33,4 \%$ & $27,9 \%$ & $94,8 \%$ & $26,4 \%$ \\
\hline
\end{tabular}




\begin{tabular}{|c|c|c|c|c|}
\hline $\begin{array}{c}\text { MINISTERIO DO MEIO } \\
\text { AMBIENTE }\end{array}$ & $53,8 \%$ & $52,9 \%$ & $98,6 \%$ & $52,1 \%$ \\
\hline $\begin{array}{c}\text { MINISTERIO DO } \\
\text { PLANEJAMENTO, } \\
\text { ORCAMENTO E GESTAO }\end{array}$ & $24,4 \%$ & $16,3 \%$ & $99,7 \%$ & $16,3 \%$ \\
\hline $\begin{array}{c}\text { MINISTERIO DO } \\
\text { DESENVOLVIMENTO } \\
\text { AGRARIO }\end{array}$ & $28,7 \%$ & $21,0 \%$ & $98,0 \%$ & $20,6 \%$ \\
\hline $\begin{array}{l}\text { MINISTERIO DO } \\
\text { ESPORTE }\end{array}$ & $14,8 \%$ & $8,0 \%$ & $96,2 \%$ & $7,7 \%$ \\
\hline MINISTERIO DA DEFESA & $53,7 \%$ & $50,2 \%$ & $98,3 \%$ & $49,3 \%$ \\
\hline $\begin{array}{l}\text { MINISTERIO DA } \\
\text { INTEGRACAO } \\
\text { NACIONAL }\end{array}$ & $27,5 \%$ & $20,3 \%$ & $96,0 \%$ & $19,5 \%$ \\
\hline $\begin{array}{l}\text { MINISTERIO DO } \\
\text { TURISMO }\end{array}$ & $15,8 \%$ & $6,8 \%$ & $99,4 \%$ & $6,8 \%$ \\
\hline $\begin{array}{c}\text { MINISTERIO DO } \\
\text { DESENVOLVIMENTO } \\
\text { SOCIAL E COMBATE À } \\
\text { FOME }\end{array}$ & $89,3 \%$ & $90,1 \%$ & $99,8 \%$ & $89,9 \%$ \\
\hline $\begin{array}{l}\text { MINISTERIO DAS } \\
\text { CIDADES }\end{array}$ & $20,8 \%$ & $15,1 \%$ & $97,8 \%$ & $14,7 \%$ \\
\hline $\begin{array}{c}\text { MINISTERIO DA PESCA E } \\
\text { AQUICULTURA }\end{array}$ & $24,7 \%$ & $25,5 \%$ & $97,1 \%$ & $24,7 \%$ \\
\hline $\begin{array}{l}\text { MINISTERIO DA PESCA E } \\
\text { AQÜICULTURA }\end{array}$ & $22,7 \%$ & $0,0 \%$ & $0,0 \%$ & $0,0 \%$ \\
\hline $\begin{array}{c}\text { CONSELHO NACIONAL } \\
\text { DO MINISTERIO } \\
\text { PUBLICO }\end{array}$ & $0,0 \%$ & $0,3 \%$ & $0,0 \%$ & $0,0 \%$ \\
\hline $\begin{array}{c}\text { ENCARGOS } \\
\text { FINANCEIROS DA UNIAO }\end{array}$ & $46,5 \%$ & $53,1 \%$ & $100,0 \%$ & $53,1 \%$ \\
\hline $\begin{array}{c}\text { TRANSFERENCIAS A } \\
\text { ESTADOS, DISTRITO } \\
\text { FEDERAL E MUNICIPIOS }\end{array}$ & $86,3 \%$ & $66,5 \%$ & $100,0 \%$ & $66,5 \%$ \\
\hline $\begin{array}{l}\text { OPERACOES OFICIAIS DE } \\
\text { CREDITO }\end{array}$ & $33,3 \%$ & $33,3 \%$ & $100,0 \%$ & $33,3 \%$ \\
\hline TOTAL & $52,4 \%$ & $53,1 \%$ & $98,0 \%$ & $52,0 \%$ \\
\hline
\end{tabular}

Fonte: Portal Siga Brasil - Link: Execução Orçamentária - Subitem: Programação Financeira/ Contingenciamento - Planilha: “Despesa Discricionária Executivo - Fiscal e Seguridade - 2012”. (adaptada pelo autor).

Ressalta-se, assim, que a diferença de comportamento está no fato de ter sido efetuado menos empenhos (no total 53\%, enquanto em 2010 o percentual de empenho foi de $86 \%$ e em 2011 de $83 \%$ ), de modo que o percentual de pagamento tenha sido maior, próximo ao que se efetivamente empenhou/liquidou (98\%). Porém, novamente, o percentual de execução ficou bem abaixo do previsto, sendo, em verdade, ainda mais baixo do que nos anos anteriores $(52,4 \%)$.

Por outro lado, no ano de 2012, com relação aos anos analisados, houve a maior aproximação da expectativa, arrecadação de $91 \%$ do que foi previsto: 
Tabela 12: Execução de Receitas do exercício de 2012, indicando, por tipo, (i) a receita prevista, (ii) a receita arrecadada, e (iii) o percentual arrecadado em relação ao previsto.

\begin{tabular}{cccc}
\hline Discriminação & Receita Prevista & $\begin{array}{c}\text { Receita Arrecadada } \\
\text { Líquida }\end{array}$ & $\begin{array}{c}\text { Percentual } \\
\text { Arrecadado }\end{array}$ \\
\hline RECEITA TOTAL & $\mathbf{2 . 1 5 0 . 4 5 8 . 8 6 7 . 5 0 7}$ & $\mathbf{1 . 9 4 9 . 2 9 6 . 9 8 8 . 6 7 2}$ & $\mathbf{9 1 \%}$ \\
$\begin{array}{c}\text { RECEITA ADMINISTRADA } \\
\text { ARRECADAÇÃO LÍQUIDA }\end{array}$ & 719.634 .587 .607 & 669.864 .471 .016 & $93 \%$ \\
$\begin{array}{c}\text { INSS } \\
\text { RECEITAS NÃO }\end{array}$ & 273.755 .165 .075 & 274.074 .961 .118 & $100 \%$ \\
ADMINISTRADAS & 132.550 .611 .147 & 149.075 .614 .007 & $112 \%$ \\
RECEITA FINANCEIRA & 1.023 .105 .166 .839 & 854.425 .184 .115 & $84 \%$ \\
NÃO INFORMADO & 1.413 .336 .839 & 1.856 .758 .417 & $131 \%$ \\
\hline
\end{tabular}

Fonte: Portal Siga Brasil - Link: Execução Orçamentária - Subitem: Receita - Planilha: Execução da Receita 2012 (adaptada pelo autor).

Portanto, o comportamento dos dados de 2012 reforça a enorme dificuldade em cumprir qualquer planejamento quanto às despesas discricionárias, mesmo quando as receitas mostraram uma maior arrecadação (em comparação com o previsto), ainda maior foi a inexecução dessas despesas. O fato de que nesse ano houve, ao menos aparentemente, uma pretensão de aproximar o empenhado do que efetivamente poderia ser pago, diminuindo-se restos a pagar, demonstra, por outro lado, que não se deve ter a menor expectativa de executar as despesas discricionárias previstas na lei orçamentária.

\subsubsection{Exercício de 2013}

Quanto ao exercício de 2013, o Poder Executivo editou o primeiro decreto de contingenciamento apenas em 02 de maio de 2013 - Decreto $n^{\circ} 7.995 / 13$. O Anexo I, que estabelece os limites de movimentação e empenho, foi alterado por duas vezes ao longo do ano. Primeiro, ainda em maio, pelo Decreto ${ }^{\circ}$ 8.021/13 e, depois, em julho, pelo Decreto $n^{\circ} 8.062 / 13$.

De se esclarecer que o orçamento de 2013 foi aprovado pela Lei ${ }^{\circ} 12.798 / 13$, que é de 04 de abril de 2013, o que justifica a tardia edição dos decretos com limitação de empenho. Ainda, duas observações são necessárias. Primeiro, o primeiro decreto, de 02 de maio de 2013, estabelecia um limite de disponibilidade até agosto, o qual se reproduz na 
tabela, e também um limite de disponibilidade até dezembro, o qual correspondia a 100\% da previsão e por isso não é considerado na presente. Segundo, com relação ao Decreto no 8.062/13, as alterações referentes ao Anexo I não vieram de forma consolidada, constando apenas os montantes de "redução dos limites de movimentação e empenho". Na tabela abaixo já se apresentam essas alterações de forma consolidada, reduzindo-se em relação ao que estava fixado no decreto anterior.

Tabela 13. Dados comparativos entre os Decretos de Contingenciamento editados no exercício de 2013, contendo, por órgão, (i) as despesas não obrigatórias ("outras despesas") fixadas na Lei Orçamentária (acrescida de créditos adicionais), (ii) as despesas não obrigatórias ("outras despesas") disponíveis, conforme limites de empenho e movimentação financeira, e (iii) o percentual de disponibilidade das despesas não obrigatórias ("outras despesas") em relação ao fixado em lei.

\begin{tabular}{|c|c|c|c|c|c|c|c|c|c|}
\hline \multirow[b]{2}{*}{ Órgão } & \multicolumn{3}{|c|}{ Decreto 7.995 (maio/2013) } & \multicolumn{3}{|c|}{ Decreto 8.021 (Maio/2013) } & \multicolumn{3}{|c|}{ Decreto 8.062 (Julho/2013) } \\
\hline & $\begin{array}{c}\text { Despesa em } \\
\text { Lei }\end{array}$ & $\begin{array}{c}\text { Disponível até } \\
\text { Agosto }\end{array}$ & $\%$ & $\begin{array}{c}\text { Despesa em } \\
\text { Lei }\end{array}$ & $\begin{array}{c}\text { Despesa } \\
\text { Disponível }\end{array}$ & $\%$ & $\begin{array}{c}\text { Despesa em } \\
\text { Lei }\end{array}$ & $\begin{array}{c}\text { Despesa } \\
\text { Disponível }\end{array}$ & $\%$ \\
\hline $\begin{array}{l}\text { PRESIDENCIA } \\
\text { DA REPUBLICA }\end{array}$ & 933.721 .205 & 920.600 .000 & $99 \%$ & 933.721 .205 & 734.703 .287 & $79 \%$ & 933.721 .205 & 668.074 .678 & $72 \%$ \\
\hline $\begin{array}{c}\text { VICE- } \\
\text { PRESIDÊNCIA DA } \\
\text { REPÚBLICA }\end{array}$ & 5.023 .000 & 5.023 .000 & $100 \%$ & 5.023 .000 & 4.500 .609 & $90 \%$ & 5.023 .000 & 3.818 .609 & $76 \%$ \\
\hline $\begin{array}{l}\text { ADVOCACIA } \\
\text { GERAL DA } \\
\text { UNIÂO }\end{array}$ & 253.292 .200 & 253.292 .200 & $100 \%$ & 253.292 .200 & 226.321 .917 & $89 \%$ & 253.292 .200 & 216.577 .608 & $86 \%$ \\
\hline $\begin{array}{l}\text { MINISTERIO DA } \\
\text { AGRICULTURA, } \\
\text { PECUARIA E } \\
\text { ABASTECIMENT. }\end{array}$ & 2.919.101.372 & 1.545.094.700 & $53 \%$ & 2.919 .101 .372 & 1.453 .422 .682 & $50 \%$ & 2.919 .101 .372 & 1.326 .130 .143 & $45 \%$ \\
\hline $\begin{array}{l}\text { MINISTERIO DA } \\
\text { CIENCIA E } \\
\text { TECNOLOGIA }\end{array}$ & 7.037.149.664 & 6.751 .965 .500 & $96 \%$ & 7.037 .149 .664 & 7.037.149.664 & $100 \%$ & 7.037.149.664 & 6.873 .923 .890 & $\mathbf{9 8 \%}$ \\
\hline $\begin{array}{l}\text { MINISTERIO DA } \\
\text { FAZENDA }\end{array}$ & 4.811.016.500 & 4.806 .016 .500 & $100 \%$ & 4.811.016.500 & 4.001 .895 .061 & $83 \%$ & 4.811.016.500 & 3.011 .845 .038 & $63 \%$ \\
\hline $\begin{array}{l}\text { MINISTERIO DA } \\
\text { EDUCACAO }\end{array}$ & 31.337.933.086 & 29.285 .532 .000 & $93 \%$ & 31.337 .933 .086 & 31.337 .933 .086 & $100 \%$ & 31.337 .933 .086 & 31.337 .933 .086 & $100 \%$ \\
\hline $\begin{array}{l}\text { MINISTERIO DO } \\
\text { DESENVOLVIME } \\
\text { NTO, INDÚSTRIA } \\
\text { E COMERCIO } \\
\text { EXTERIOR }\end{array}$ & 1.234 .925 .232 & 1.082 .379 .010 & $\mathbf{8 8 \%}$ & 1.234 .925 .232 & 982.753 .358 & $80 \%$ & 1.234 .925 .232 & 896.920 .119 & $73 \%$ \\
\hline $\begin{array}{l}\text { MINISTERIO DA } \\
\text { JUSTICA }\end{array}$ & 4.425 .128 .236 & 3.863 .284 .778 & $87 \%$ & 4.579 .062 .086 & 3.670 .489 .526 & $80 \%$ & 4.579 .062 .086 & 3.394 .545 .950 & $74 \%$ \\
\hline $\begin{array}{c}\text { MINISTERIO DE } \\
\text { MINAS E } \\
\text { ENERGIA }\end{array}$ & 979.161 .133 & 861.411 .133 & $88 \%$ & 979.161 .133 & 825.202 .332 & $84 \%$ & 979.161 .133 & 773.137 .591 & $79 \%$ \\
\hline $\begin{array}{l}\text { MINISTERIO DA } \\
\text { PREVIDENCIA } \\
\text { SOCIAL }\end{array}$ & 2.027.066.844 & 2.004 .861 .200 & $99 \%$ & 2.031 .066 .844 & 1.705 .316 .548 & $84 \%$ & 2.031 .066 .844 & 1.424 .644 .699 & $70 \%$ \\
\hline $\begin{array}{l}\text { MINISTERIO DAS } \\
\text { RELACOES } \\
\text { EXTERIORES }\end{array}$ & 950.027 .600 & 950.027 .600 & $100 \%$ & 951.527 .600 & 851.479 .081 & $89 \%$ & 951.527 .600 & 704.766 .915 & $74 \%$ \\
\hline $\begin{array}{l}\text { MINISTERIO DA } \\
\text { SAUDE }\end{array}$ & 21.689 .973 .847 & 17.061.426.732 & $79 \%$ & 21.689 .973 .847 & 21.689 .973 .847 & $100 \%$ & 21.689 .973 .847 & 21.689 .973 .847 & $100 \%$ \\
\hline $\begin{array}{c}\text { MINISTERIO DO } \\
\text { TRABALHO E } \\
\text { EMPREGO }\end{array}$ & 1.198 .677 .402 & 1.021 .320 .400 & $85 \%$ & 1.199 .877 .402 & 929.444 .558 & $77 \%$ & 1.199 .877 .402 & 869.612 .208 & $72 \%$ \\
\hline $\begin{array}{l}\text { MINISTERIO DOS } \\
\text { TRANSPORTES }\end{array}$ & 17.558.249.206 & 16.509 .065 .095 & $94 \%$ & 17.572 .759 .797 & 16.311 .048 .872 & $93 \%$ & 17.572 .759 .797 & 16.219 .189 .822 & $92 \%$ \\
\hline
\end{tabular}




\begin{tabular}{|c|c|c|c|c|c|c|c|c|c|}
\hline $\begin{array}{l}\text { MINISTERIO DAS } \\
\text { COMUNICACOES }\end{array}$ & 783.769 .720 & 767.919 .720 & $98 \%$ & 783.769 .720 & 732.279 .497 & $93 \%$ & 783.769 .720 & 696.565 .716 & $89 \%$ \\
\hline $\begin{array}{l}\text { MINISTERIO DA } \\
\text { CULTURA }\end{array}$ & 2.451 .520 .887 & 1.748 .957 .700 & $71 \%$ & 2.451 .520 .887 & 1.684 .399 .050 & $69 \%$ & 2.451 .520 .887 & 1.598 .462 .609 & $65 \%$ \\
\hline $\begin{array}{l}\text { MINISTERIO DO } \\
\text { MEIO AMBIENTE }\end{array}$ & 1.045 .686 .442 & 993.173 .200 & $95 \%$ & 1.045 .686 .442 & 912.733 .967 & $87 \%$ & 1.045 .686 .442 & 805.627 .364 & $77 \%$ \\
\hline $\begin{array}{l}\text { MINISTERIO DO } \\
\text { PLANEJAMENTO, } \\
\text { ORCAMENTO E } \\
\text { GESTAO }\end{array}$ & 1.077 .702 .728 & 1.077 .502 .728 & $100 \%$ & 1.077 .702 .728 & 920.528 .008 & $85 \%$ & 1.077 .702 .728 & 703.883 .235 & $65 \%$ \\
\hline $\begin{array}{l}\text { MINISTERIO DO } \\
\text { DESENVOLVIME } \\
\text { NTO AGRARIO }\end{array}$ & 3.588 .991 .900 & 2.988 .558 .963 & $83 \%$ & 3.588 .991 .900 & 2.701 .060 .843 & $75 \%$ & 3.588 .991 .900 & 2.557 .970 .049 & $71 \%$ \\
\hline $\begin{array}{l}\text { MINISTERIO DO } \\
\text { ESPORTE }\end{array}$ & 3.245.012.109 & 1.756 .531 .788 & $54 \%$ & 3.245 .012 .109 & 1.745 .023 .768 & $54 \%$ & 3.245 .012 .109 & 1.728 .993 .129 & $53 \%$ \\
\hline $\begin{array}{l}\text { MINISTERIO DA } \\
\text { DEFESA }\end{array}$ & 14.841 .933 .989 & 13.809 .775 .322 & $93 \%$ & 15.058 .774 .187 & 11.380 .947 .449 & $76 \%$ & 15.058.774.187 & 10.461 .514 .928 & $69 \%$ \\
\hline $\begin{array}{l}\text { MINISTERIO DA } \\
\text { INTEGRACAO } \\
\text { NACIONAL }\end{array}$ & 8.026 .543 .165 & 6.432 .307 .000 & $80 \%$ & 8.026 .543 .165 & 6.400 .294 .432 & $80 \%$ & 8.026 .543 .165 & 6.353 .766 .385 & $79 \%$ \\
\hline $\begin{array}{l}\text { MINISTERIO DO } \\
\text { TURISMO }\end{array}$ & 2.657 .281 .455 & 729.737 .900 & $27 \%$ & 2.657 .281 .455 & 689.892 .828 & $26 \%$ & 2.657 .281 .455 & 664.270 .849 & $25 \%$ \\
\hline $\begin{array}{l}\text { MINISTERIO DO } \\
\text { DESENVOLVIME } \\
\text { NTO SOCIAL E } \\
\text { COMBATE À } \\
\text { FOME }\end{array}$ & 6.556 .250 .455 & 6.432 .617 .700 & $98 \%$ & 6.556 .250 .455 & 6.556 .250 .455 & $100 \%$ & 6.556 .250 .455 & 6.518 .282 .589 & $99 \%$ \\
\hline $\begin{array}{l}\text { MINISTERIO DAS } \\
\text { CIDADES }\end{array}$ & 24.425 .748 .071 & 19.650 .772 .800 & $80 \%$ & 24.425 .748 .071 & 19.400 .683 .646 & $79 \%$ & 24.425 .748 .071 & 19.314 .164 .746 & $79 \%$ \\
\hline $\begin{array}{l}\text { MINISTERIO DA } \\
\text { PESCA E } \\
\text { AQÜICULTURA }\end{array}$ & 595.142 .408 & 263.725 .000 & $44 \%$ & 595.142 .408 & 244.522 .180 & $41 \%$ & 595.142 .408 & 231.039 .215 & $39 \%$ \\
\hline $\begin{array}{c}\text { ENCARGOS } \\
\text { FINANCEIROS DA } \\
\text { UNIAO }\end{array}$ & 941.865 .009 & 941.865 .009 & $100 \%$ & 941.865 .009 & 877.282 .105 & $93 \%$ & 941.865 .009 & 697.837 .113 & $74 \%$ \\
\hline $\begin{array}{c}\text { TRANSFERENC. A } \\
\text { ESTADOS, } \\
\text { DISTRITO } \\
\text { FEDERAL E } \\
\text { MUNICIPIOS } \\
\end{array}$ & 14.765 .000 & 14.715 .000 & $100 \%$ & 14.765 .000 & 13.121 .181 & $89 \%$ & 14.765 .000 & 12.713 .701 & $86 \%$ \\
\hline TOTAL OFICIAL & 172.427 .360 .612 & 148.917 .223 .437 & $86 \%$ & 172.868 .575 .181 & 150.124 .644 .105 & $87 \%$ & 172.868 .575 .181 & 145.804 .838 .869 & $84 \%$ \\
\hline
\end{tabular}

Fonte: Anexo I do Decreto 7.995/2013 (alterado pelo Decreto $n^{\circ}$ 8.021/2013, Decreto $n^{\circ}$ 8.062/2013) (elaborada pelo autor).

O quadro acima não demonstra muito diferença do que ocorreu nos anos anteriores. Ao longo do ano, não se identifica proporcionalidade entre os órgãos. Mesmo que no último contingenciamento tenham sido disponibilizadas menos despesas do que no primeiro contingenciamento, alguns órgãos aumentaram o disponível, caso do Ministério da Saúde, outros diminuíram significativamente (caso do Ministério da Fazenda).

Quanto aos Relatórios de Avaliação, de se destacar que não foi divulgado relatório para o $1^{\circ}$ Bimestre, possivelmente em decorrência da aprovação tardia do orçamento. No $2^{\circ}$ Bimestre, a indicação de limite para o Executivo ficou em 22 bilhões, sendo alterada para 26 bilhões no $3^{\circ}$ bimestre, e depois para 24 bilhões no $5^{\circ}$ bimestre. Comparando-os com os decretos, houve um contingenciamento em valores relativamente próximos ao indicado. 
Tabela 14. Evolução (ampliação ou redução) dos limites de empenho e movimentação financeira indicados para o Executivo pelo Relatório de Avaliação Bimestral em 2013. Em milhões.

\begin{tabular}{|c|c|c|c|c|c|}
\hline & $1^{\circ}$ Bimestre & $2^{\circ}$ Bimestre & $3^{\circ}$ Bimestre & $4^{\circ}$ Bimestre & $5^{\circ}$ Bimestre \\
\hline $\begin{array}{c}\text { Ampliação/Redução } \\
\text { sugerido para a } \\
\text { Limitação de empenho e } \\
\text { movimentação financeira } \\
\text { do Executivo }\end{array}$ & Sem avaliação & $\mathrm{R} \$ 22.287$ & $\mathrm{R} \$ 4.320$ & $\mathrm{R} \$ 0$ & $-\mathrm{R} \$ 2.201$ \\
\hline $\begin{array}{c}\text { Total da Limitação } \\
\text { (soma da } \\
\text { ampliação/redução do } \\
\text { bimestre atual com o } \\
\text { totalizado do bimestre } \\
\text { anterior) }\end{array}$ & $\mathrm{R} \$ 0,00$ & $\mathrm{R} \$ 22.287$ & $\mathrm{R} \$ 26.606$ & $\mathrm{R} \$ 26.606$ & $\mathrm{R} \$ 24.405$ \\
\hline
\end{tabular}

Fonte: Relatórios de Avaliação Bimestral do exercício de 2013 (elaborado pelo autor).

No tocante aos percentuais de execução orçamentária, nota-se um comportamento semelhante ao de 2010 e 2011, com um percentual de empenho/liquidação de $80 \%$, mas, por outro lado, um percentual bastante baixo no tocante ao pagamento: 54\%. E assim como já observado nos anos anteriores, a execução, especialmente de alguns órgãos, muito abaixo do previsto.

Tabela 15: Dados da Execução Orçamentária das despesas discricionárias em 2013, contendo, por órgão, (i) percentual executado (metodologia do Siga Brasil); (ii) \% empenhado/liquidado (em relação ao autorizado); (iii) percentual pago em relação ao empenhado/liquidado; e (iv) percentual pago em relação ao autorizado

\begin{tabular}{|c|c|c|c|c|}
\hline Órgão (Cod/Desc) & $\%$ Executado & $\begin{array}{c}\% \\
\text { Liquidado }\end{array}$ & $\begin{array}{c}\text { \% Pago } \\
\text { (sobre } \\
\text { liquidado) } \\
\end{array}$ & $\begin{array}{l}\text { \% Pago (sobre } \\
\text { autorizado) }\end{array}$ \\
\hline $\begin{array}{l}\text { CONSELHO NACIONAL DE } \\
\text { JUSTIÇA }\end{array}$ & $0 \%$ & $0 \%$ & $0 \%$ & $0 \%$ \\
\hline $\begin{array}{l}\text { PRESIDÊNCIA DA } \\
\text { REPÚBLICA }\end{array}$ & $58 \%$ & $65 \%$ & $63 \%$ & $41 \%$ \\
\hline $\begin{array}{c}\text { MINISTÉRIO DA } \\
\text { AGRICULTURA, PECUÁRIA } \\
\text { E ABASTECIMENTO }\end{array}$ & $32 \%$ & $72 \%$ & $36 \%$ & $26 \%$ \\
\hline $\begin{array}{l}\text { MINISTÉRIO DA CIÊNCIA E } \\
\text { TECNOLOGIA }\end{array}$ & $63 \%$ & $0 \%$ & $0 \%$ & $0 \%$ \\
\hline $\begin{array}{l}\text { MINISTÉRIO DA CIÊNCIA, } \\
\text { TECNOLOGIA E INOVAÇÃOO }\end{array}$ & $50 \%$ & $83 \%$ & $60 \%$ & $50 \%$ \\
\hline MINISTÉRIO DA FAZENDA & $41 \%$ & $50 \%$ & $74 \%$ & $37 \%$ \\
\hline $\begin{array}{l}\text { MINISTÉRIO DA } \\
\text { EDUCAÇÃO }\end{array}$ & $59 \%$ & $85 \%$ & $68 \%$ & $57 \%$ \\
\hline $\begin{array}{c}\text { MINISTÉRIO DO } \\
\text { DESENVOLVIMENTO, IND. } \\
\text { E COMÉRCIO EXTERIOR }\end{array}$ & $41 \%$ & $45 \%$ & $87 \%$ & $39 \%$ \\
\hline
\end{tabular}




\begin{tabular}{|c|c|c|c|c|}
\hline MINISTÉRIO DA JUSTIÇA & $40 \%$ & $71 \%$ & $48 \%$ & $35 \%$ \\
\hline $\begin{array}{l}\text { MINISTÉRIO DE MINAS E } \\
\text { ENERGIA }\end{array}$ & $7 \%$ & $9 \%$ & $60 \%$ & $6 \%$ \\
\hline $\begin{array}{c}\text { MINISTÉRIO DA } \\
\text { PREVIDÊNCIA SOCIAL }\end{array}$ & $71 \%$ & $81 \%$ & $86 \%$ & $69 \%$ \\
\hline $\begin{array}{c}\text { MINISTÉRIO DAS } \\
\text { RELAÇÕES EXTERIORES }\end{array}$ & $89 \%$ & $91 \%$ & $97 \%$ & $88 \%$ \\
\hline MINISTÉRIO DA SAÚDE & $77 \%$ & $91 \%$ & $89 \%$ & $81 \%$ \\
\hline $\begin{array}{c}\text { MINISTÉRIO DO } \\
\text { TRABALHO E EMPREGO }\end{array}$ & $18 \%$ & $22 \%$ & $50 \%$ & $11 \%$ \\
\hline $\begin{array}{l}\text { MINISTÉRIO DOS } \\
\text { TRANSPORTES }\end{array}$ & $44 \%$ & $88 \%$ & $34 \%$ & $30 \%$ \\
\hline $\begin{array}{l}\text { MINISTÉRIO DAS } \\
\text { COMUNICAÇÕES }\end{array}$ & $10 \%$ & $16 \%$ & $49 \%$ & $8 \%$ \\
\hline MINISTÉRIO DA CULTURA & $30 \%$ & $62 \%$ & $37 \%$ & $23 \%$ \\
\hline $\begin{array}{c}\text { MINISTÉRIO DO MEIO } \\
\text { AMBIENTE }\end{array}$ & $25 \%$ & $30 \%$ & $76 \%$ & $23 \%$ \\
\hline $\begin{array}{c}\text { MINISTÉRIO DO } \\
\text { PLANEJAMENTO, } \\
\text { ORÇAMENTO E GESTÃO }\end{array}$ & $58 \%$ & $86 \%$ & $59 \%$ & $51 \%$ \\
\hline $\begin{array}{c}\text { MINISTÉRIO DO } \\
\text { DESENVOLVIMENTO } \\
\text { AGRÁRIO }\end{array}$ & $30 \%$ & $82 \%$ & $30 \%$ & $25 \%$ \\
\hline MINISTÉRIO DO ESPORTE & $15 \%$ & $56 \%$ & $16 \%$ & $9 \%$ \\
\hline MINISTÉRIO DA DEFESA & $57 \%$ & $88 \%$ & $61 \%$ & $53 \%$ \\
\hline $\begin{array}{c}\text { MINISTÉRIO DA } \\
\text { INTEGRAÇÃO NACIONAL }\end{array}$ & $42 \%$ & $82 \%$ & $48 \%$ & $40 \%$ \\
\hline MINISTÉRIO DO TURISMO & $15 \%$ & $60 \%$ & $10 \%$ & $6 \%$ \\
\hline $\begin{array}{c}\text { MINISTÉRIO DO } \\
\text { DESENVOLVIMENTO } \\
\text { SOCIAL E COMBATE À } \\
\text { FOME }\end{array}$ & $89 \%$ & $97 \%$ & $93 \%$ & $90 \%$ \\
\hline MINISTÉRIO DAS CIDADES & $31 \%$ & $82 \%$ & $36 \%$ & $30 \%$ \\
\hline $\begin{array}{l}\text { MINISTÉRIO DA PESCA E } \\
\text { AQUICULTURA }\end{array}$ & $15 \%$ & $45 \%$ & $34 \%$ & $15 \%$ \\
\hline $\begin{array}{l}\text { CONSELHO NACIONAL DO } \\
\text { MINISTÉRIO PÚBLICO }\end{array}$ & $0 \%$ & $0 \%$ & $0 \%$ & $0 \%$ \\
\hline $\begin{array}{l}\text { GABINETE DA VICE- } \\
\text { PRESIDÊNCIA DA } \\
\text { REPÚBLICA }\end{array}$ & $61 \%$ & $71 \%$ & $86 \%$ & $61 \%$ \\
\hline $\begin{array}{c}\text { SECRETARIA DE } \\
\text { ASSUNTOS ESTRATÉGICOS }\end{array}$ & $61 \%$ & $72 \%$ & $85 \%$ & $61 \%$ \\
\hline $\begin{array}{l}\text { SECRETARIA DE AVIAÇÃO } \\
\text { CIVIL }\end{array}$ & $40 \%$ & $59 \%$ & $68 \%$ & $40 \%$ \\
\hline $\begin{array}{l}\text { ADVOCACIA-GERAL DA } \\
\text { UNIÃO }\end{array}$ & $82 \%$ & $93 \%$ & $89 \%$ & $82 \%$ \\
\hline $\begin{array}{c}\text { SECRETARIA DE DIREITOS } \\
\text { HUMANOS }\end{array}$ & $25 \%$ & $71 \%$ & $35 \%$ & $25 \%$ \\
\hline $\begin{array}{c}\text { SECRETARIA DE } \\
\text { POLÍTICAS PARA AS } \\
\text { MULHERES }\end{array}$ & $19 \%$ & $72 \%$ & $27 \%$ & $19 \%$ \\
\hline $\begin{array}{c}\text { CONTROLADORIA-GERAL } \\
\text { DA UNIÃO }\end{array}$ & $81 \%$ & $93 \%$ & $87 \%$ & $81 \%$ \\
\hline $\begin{array}{l}\text { SECRETARIA DE } \\
\text { POLÍTICAS DE PROMOÇÃO } \\
\text { DA IGUALDADE RACIAL }\end{array}$ & $41 \%$ & $57 \%$ & $72 \%$ & $41 \%$ \\
\hline
\end{tabular}




\begin{tabular}{ccccc} 
SECRETARIA DE PORTOS & $10 \%$ & $73 \%$ & $14 \%$ & $10 \%$ \\
ENCARGOS FINANCEIROS & $20 \%$ & $56 \%$ & $44 \%$ & $25 \%$ \\
$\begin{array}{c}\text { DA UNIÃO } \\
\text { TRANSFERÊNCIAS A }\end{array}$ & $96 \%$ & $91 \%$ & $99 \%$ & $90 \%$ \\
$\begin{array}{c}\text { ESTADOS, DISTRITO } \\
\text { FEDERAL E MUNICÍPIOS } \\
\text { OPERAÇÕES OFICIAIS DE } \\
\begin{array}{c}\text { CRÉDITO } \\
\text { RESERVA DE }\end{array}\end{array}$ & $27 \%$ & $99 \%$ & $28 \%$ & $28 \%$ \\
CONTINGÊNCIA & $0 \%$ & $0 \%$ & $0 \%$ & $0 \%$ \\
\hline TOTAL & $\mathbf{5 4 \%}$ & $80 \%$ & $68 \%$ & $54 \%$ \\
\hline
\end{tabular}

Fonte: Portal Siga Brasil - Link: Execução Orçamentária - Subitem: Programação Financeira/ Contingenciamento - Planilha: "Despesa Discricionária Executivo - Fiscal e Seguridade - 2013”. (adaptada pelo autor).

Considerando apenas os Ministérios, dezesseis ficaram abaixo com execução orçamentária de despesas discricionárias abaixo de $50 \%$ do previsto. Retoma-se aqui o comportamento de empenhar/liquidar muito mais do que efetivamente se pretende pagar. $\mathrm{E}$ ainda pior é que a lei orçamentária (para despesas discricionárias) permanece longe de ser executada próxima do previsto.

Por fim, quanto à previsão de receitas, verifica-se que o percentual de arrecadação foi de $87 \%$, mais uma vez um comportamento bastante distinto se comparado à execução de despesas discricionárias:

Tabela 16. Execução de Receitas do exercício de 2013, indicando, por tipo, (i) a receita prevista, (ii) a receita arrecadada, e (iii) o percentual arrecadado em relação ao previsto.

\begin{tabular}{cccc}
\hline Discriminação & Receita Prevista & $\begin{array}{c}\text { Receita Arrecadada } \\
\text { Líquida }\end{array}$ & $\begin{array}{c}\text { Percentual } \\
\text { Arrecadado }\end{array}$ \\
\hline RECEITA TOTAL & $\mathbf{R} \$ \mathbf{2 . 1 6 5 . 9 1 0 . 8 0 5 . 6 6 9 , 0 0}$ & $\mathbf{R} \$ \mathbf{1 . 8 8 4 . 5 6 6 . 5 2 4 . 6 1 4 , 2 2}$ & $\mathbf{8 7 \%}$ \\
RECEITA & $\mathrm{R} \$ 746.548 .460 .843,00$ & $\mathrm{R} \$ 716.795 .839 .380,28$ & $96 \%$ \\
$\begin{array}{c}\text { ADMINISTRADA } \\
\text { ARRECADAÇÃO }\end{array}$ & $\mathrm{R} \$ 310.507 .340 .115,00$ & $\mathrm{R} \$ 297.692 .923 .074,73$ & $96 \%$ \\
$\begin{array}{c}\text { LÍQUIDA INSS } \\
\text { RECEITAS NÃO }\end{array}$ & $\mathrm{R} \$ 150.709 .824 .535,00$ & $\mathrm{R} \$ 106.284 .888 .966,53$ & $71 \%$ \\
ADMINISTRADAS & & & \\
$\begin{array}{c}\text { RECEITA } \\
\text { FINANCEIRA }\end{array}$ & $\mathrm{R} \$ 912.513 .716 .361,00$ & $\mathrm{R} \$ 706.597 .159 .868,36$ & $77 \%$ \\
NÃO INFORMADO & $\mathrm{R} \$ 45.631 .463 .815,00$ & $\mathrm{R} \$ 57.195 .713 .324,32$ & $125 \%$ \\
\hline
\end{tabular}

Fonte: Portal Siga Brasil - Link: Execução Orçamentária - Subitem: Receita - Planilha: Execução da Receita 2013 (adaptada pelo autor). 


\subsection{Considerações gerais sobre os dados apresentados}

O objetivo da análise efetuada foi ilustrar com dados as críticas doutrinárias e as observações de diversos meios de comunicação sobre o contingenciamento. Dar um passo a mais em relação à bibliografia que criticava a aplicação do contingenciamento.

A acusação majoritária é no sentido de que o Executivo utiliza de forma arbitrária o referido instrumento de flexibilização orçamentária, o que significa, primeiro, a inobservância dos limites e parâmetros jurídicos na sua prática e, segundo, prejuízos a diversos aspectos da execução orçamentária, a exemplo da transparência, do planejamento, da legitimidade democrática e do controle.

Algumas considerações gerais sobre o comportamento verificado nos dados se fazem necessárias. Tais considerações levam em conta que a análise foi feita a partir de números gerais e finais, os quais, se não permitem conclusões numericamente precisas, possibilitam algumas reflexões ${ }^{217}$.

Em primeiro lugar, de se destacar que a execução orçamentária (considerando receita e despesa) seguiu comportamentos semelhantes nos exercícios analisados. Pode-se apontar, em suma, o seguinte:

(i) A receita total arrecadada em relação ao que foi estimado no orçamento foi, nos anos analisados (2010 a 2013), respectivamente de 84\%, 87\%, $91 \%$ e $87 \%$, em relação ao previsto. Veja-se que não se chegou ao estimado, porém, não houve uma distância drástica - diferença de ao menos $9 \%$ e no máximo de $16 \%$. Em média, arrecadou-se $87,3 \%$ do previsto (ou $12,7 \%$ a menos do que o previsto).

Tabela 17. Total de receita arrecadada em relação ao previsto nos anos de 2010 a 2013

\begin{tabular}{cccccc}
\hline Ano & 2010 & 2011 & 2012 & 2013 & Média \\
\hline $\begin{array}{c}\text { Percentual } \\
\text { Arrecadado }\end{array}$ & $84 \%$ & $87 \%$ & $91 \%$ & $87 \%$ & $\mathbf{8 7 , 3 \%}$ \\
\hline
\end{tabular}

${ }^{217}$ É certo que uma análise mensal e mais detalhada, considerando mais variáveis e mais comparações, permitiria conclusões numericamente mais precisas. Porém, se assim fosse, o objetivo do presente trabalho seria alterado. Pretende-se aqui uma discussão majoritariamente jurídica e não uma descrição estatística do tema. Entende-se que os números apresentados possibilitam apontar caminhos e um olhar mais profundo para o mecanismo do contingenciamento. Ademais, uma análise numericamente mais detalhada esbarraria também na dificuldade de obtenção de dados, seja por não estarem disponíveis, seja por não estarem classificados de forma comparável. Reteira-se que, a partir das diversas críticas e observações doutrinárias, a apresentação e análise dos dados visam dar um passo a mais na compreensão do contingenciamento e, consequentemente, do Direito Financeiro. 
(ii) Quanto aos montantes totais disponibilizados, considerando o percentual final (ou seja, a última alteração do Anexo $I$ do decreto de contingenciamento) para cada ano, também se notou um comportamento nos anos analisados: 80\%, 79\%, 78\% e 84\% disponibilizado em relação ao aprovado. Ou seja, do total aprovado, o Executivo disponibilizou, em média, $80 \%$. Olhando para esse número, não há um resultado drástico, especialmente considerando a arrecadação e os superavit primários. É, ainda, possível que haja montantes disponibilizados sem que haja previsão específica nos Decretos ou, então, montantes que embora "descontingenciados" não sejam efetivamente executados (empenhados, liquidados e pagos), mas cujos efeitos são apenas visualizados nas tabelas de execução.

O que se observa com preocupação, sem dúvida, é que os montantes disponibilizados para alguns órgãos estão muito abaixo do previsto. Citam-se como exemplos o Ministério do Turismo, com média de 31\%; o Ministério do Esporte com 41\%; e o Ministério da Agricultura com 54\% (cálculos realizados considerando as tabelas anteriores). Que planejamento é esperado para esses órgãos? Qual será o nível de realização das políticas públicas para esses mesmos órgãos?

(iii) Quanto à comparação entre as indicações de contingenciamento feitas pelos Relatórios de Avaliação Bimestral e o contingenciamento determinado nos Decretos, constata-se que este (contingenciamento efetivo) tem sido um pouco maior do que o sugerido. Ou seja, são disponibilizadas menos despesas do que o Relatório indica ser possível, sendo certo que nem sempre as indicações de ampliação dos limites (aumento das despesas disponíveis) são espelhadas nos Decretos. Aqui, há duas possibilidade, ambas preocupantes: ou os decretos de contingenciamento de fato não seguem as recomendações e análise dos relatórios, ou não há transparência na disponibilização dos gastos, já que não se consolidam em alterações no Anexo do decreto.

(iv) Quanto à execução das despesas, torna-se mais difícil identificar um comportamento uniforme. O que se pode constatar com segurança é que os percentuais de execução orçamentária das despesas discricionárias, seja 
considerando restos a pagar, seja considerando apenas o empenhado/liquidado, seja considerando os pagamentos do ano corrente, estão bem abaixo do que é aprovado na lei orçamentária anual. Em termos percentuais, estão baixos se comparado com o comportamento da arrecadação.

A tabela abaixo mostra os percentuais totais de execução (conforme metodologia oficial), percentuais de empenho/liquidação sobre autorizado, percentuais de pago sobre liquidado, e pago sobre autorizado, dos anos analisados. Mostra, ainda, a média referente aos valores totais nesses anos.

Em termos totais, verifica-se que, na média de 2010 a 2013, a execução (considerando restos a pagar) foi de 56\%, o empenhado/liquidado foi de $76 \%$ do autorizado e foi pago apenas $56 \%$ do autorizado. Uma observação interessante, já feita, é que no ano de 2012, o percentual empenhado/liquidado foi bem menor do que os demais anos (53\%), porém, quase a totalidade do que foi empenhado/liquidado foi pago (98\%), deixando quantidade menor de restos a pagar. Tal comportamento não se verificou nos demais anos.

Tabela 18. Evolução dos percentuais de execução, empenho e pagamento das despesas discricionárias do Executivo nos anos de 2010 a 2013 (elaborada pelo autor).

\begin{tabular}{ccccc}
\hline Ano & \% Executado & $\begin{array}{c}\text { \% Empenhado/ } \\
\text { Liquidado }\end{array}$ & $\begin{array}{c}\text { \% Pago (sobre } \\
\text { liquidado) }\end{array}$ & $\begin{array}{c}\text { \% Pago (sobre } \\
\text { autorizado) }\end{array}$ \\
\hline $\mathbf{2 0 1 0}$ & $59 \%$ & $86 \%$ & $71 \%$ & $61 \%$ \\
$\mathbf{2 0 1 1}$ & $57 \%$ & $83 \%$ & $69 \%$ & $58 \%$ \\
$\mathbf{2 0 1 2}$ & $52 \%$ & $53 \%$ & $98 \%$ & $52 \%$ \\
$\mathbf{2 0 1 3}$ & $54 \%$ & $80 \%$ & $68 \%$ & $54 \%$ \\
\hline Média & $\mathbf{5 6 \%}$ & $\mathbf{7 6 \%}$ & $\mathbf{7 7 \%}$ & $\mathbf{5 6 \%}$ \\
\hline
\end{tabular}

(v) Chama atenção, também, a ausência de linearidade e proporcionalidade na execução (ou mesmo na disponibilização) entre os órgãos do Executivo.

Não há uma proximidade de todos à média geral. Alguns estão bem próximos à média, outros bem abaixo e outros bem acima. Citam-se como exemplos: o Ministério do Esporte sempre com percentuais de execução ou pagamento muito baixos ${ }^{218}$ e, de outro lado, o Ministério do Desenvolvimento Social e de

\footnotetext{
${ }^{218}$ Causa estranheza pensar que, às vésperas da Copa do Mundo, as despesas discricionárias do orçamento do Ministério do Esporte continuem pouco executadas. Ocorre que, pelas informações do Ministro do Esporte, não há recursos do orçamento do Governo Federal na construção dos estádios (há financiamento do BNDES), e os recursos do orçamento federal utilizados são majoritariamente voltados para obras de infraestrutura, ou
} 
Combate à Fome com percentuais sempre altos (em parte explicados por ressalvas da LDO).

(vi) Ainda com relação aos efeitos do contingenciamento sobre cada órgão, é muito difícil identificar os critérios pelos quais o Executivo disponibiliza ou não recursos, o que, inclusive, confirma algumas análises no sentido de que o contingenciamento é utilizado para fins políticos, para controle do Legislativo e da base aliada.

(vii) De se esclarecer também a dificuldade na identificação do caminho seguido a partir do contingenciamento de recursos, especialmente porque não há retomada proporcional quando da recuperação da receita, conforme determina a Lei de Responsabilidade Fiscal ( $\operatorname{artigo} 9^{\circ}, \S 1^{\circ}$ ). Basta olhar para o "sobe e desce" das despesas, entre os órgãos, independentemente de ampliação ou redução do contingenciamento. Ou seja, mesmo que o órgão tenha sido atingido pelo decreto no início do ano, não há qualquer expectativa de que será contemplado por uma liberação de recursos no final do ano (mesmo que essa ocorra para os demais órgãos).

(viii) Por fim, comparam-se graficamente os percentuais de execução de receita e os percentuais de execução e de pagamento (em relação ao autorizado) de despesas discricionárias, no qual se verifica um significante espaço, indicando os efeitos do contingenciamento e da baixa execução orçamentária, em face do que é arrecadado.

seja, são oriundas de outros Ministérios (Conforme noticiado pelo Ministério do Esporte em http://esporte.gov.br/index.php/institucional/futebol-e-direitos-do-torcedor/copa-2014/noticias-copa2014/127-noticias-copa-2014/34307-governo-federal-detalha-investimentos-feitos-no-pais-para-a-copa-domundo. Acesso em 03/06/2014. Acesso em 03/06/2014). Ainda, conforme documento de detalhamento dos "Impactos Econômicos da Copa 2014" (dados de 2010), consta que seriam aplicados em infraestrutura e serviços diretamente do Orçamento Geral da União: 4,8 bilhões em aeroportos; 0,7 bilhões em portos; 2,0 bilhões em serviços de segurança e 0,5 bilhões em serviços de saúde (os demais recursos são de financiamento federal ou recursos da iniciativa privada). Dados obtidos em BRASIL, Ministério do Esporte. Impactos econômicos da realização da Copa 2014 no Brasil. 31/03/2010. Disponível em http://www.esporte.gov.br/arquivos/futebolDireitosTorcedor/copa2014/estudoSobreImpactosEconomicosCop aMundo2014.pdf. Acesso em 03/06/2014. 
Figura 1. Comparação entre percentual total arrecadado de receita e percentual executado e pago das despesas discricionárias do Executivo, nos anos de 2010 a 2013 (elaborada pelo autor) ${ }^{219}$.

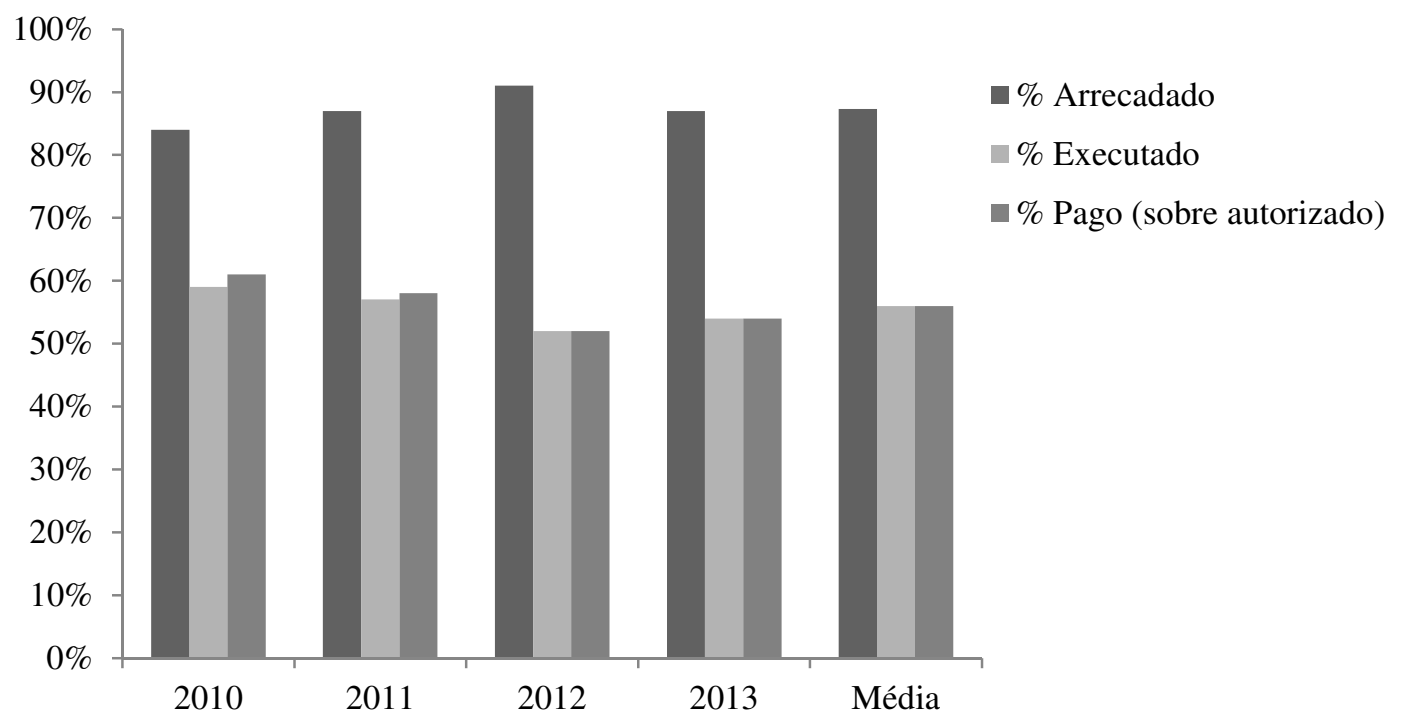

Da referida figura, o mais interessante de se notar é que a inexecução de despesas discricionárias não esteve relacionada à arrecadação. Na série analisada, tem-se que no ano de 2012, o percentual de arrecadação se aproximou ao máximo do previsto, ao passo que o percentual executado (despesas discricionárias) foi o menor na série. De outro lado, o percentual arrecadado em 2010 foi o menor, enquanto o executado (despesas discricionárias) foi o maior.

É bem verdade que a comparação não pode ser direta, em termos numéricos, já que não se considera o total de despesas, mas apenas as despesas discricionárias. Porém, a comparação pode ser avaliada em termos de comportamento. O que se quer apontar é que, de um lado, a receita arrecadada não tem uma grande variação em relação ao previsto, ao passo que a despesa discricionária essa sim apresenta uma grande variação, de forma recorrente. Daí se conclui que há evidentes problemas no planejamento, na transparência e no controle do gasto público, principalmente devido à falta de critérios. Nessa linha, os dados apresentados reforçam as suspeitas doutrinárias no sentido de que há descumprimento dos pressupostos legais para o uso do contingenciamento, o que exige adequações tanto na elaboração quanto na execução orçamentária.

\footnotetext{
${ }^{219}$ Lembra-se que o percentual executado está em conformidade com a metodologia oficial utilizada pelo SigaBrasil (considera restos a pagar), por isso há uma pequena diferença com o percentual pago.
} 


\subsection{Execução orçamentária e superavit primário}

Às considerações gerais sobre os dados apresentados, é importante adicionar mais um elemento, já mencionado ao longo do trabalho, mas que merece mais algumas reflexões. Trata-se do superavit primário.

Conforme já definido, o superavit primário é o resultado positivo entre receitas e despesas, excluídos os gastos com pagamento de juros da dívida. Em termos práticos, representa a economia feita pelo governo para pagamento da dívida, sendo um importante indicador da credibilidade e do controle das contas públicas pelo Governo perante o mercado. Basicamente, a análise do resultado primário, por excluir dos gastos totais os juros nominais devidos, servirá como medidor "de como as ações correntes do setor público afetam a trajetória de seu endividamento líquido" e, ainda, avaliam "a sustentabilidade da política fiscal em um dado exercício financeiro, tendo em vista o patamar atual da dívida consolidada e a capacidade de pagamento da mesma pelo setor público no longo prazo"220.

Os dados apresentados mostram um determinado comportamento quanto às receitas e às despesas discricionárias na série analisada: de um lado, a arrecadação aproxima-se do que foi previsto (média 87,3\%); de outro lado, a execução de despesas discricionárias fica muito abaixo do que se fixa inicialmente. Essa diferença de comportamento é também decorrente da busca por superavit primário ${ }^{221}$.

À primeira vista, esse comportamento poderia não ser um problema, já que o resultado primário positivo é de fato uma meta a ser alcançada. Porém, um olhar mais atento suscita algumas preocupações.

Primeiramente, porque quando as despesas são fixadas pela Lei Orçamentária Anual, já se sabe as metas de resultado que devem ser alcançadas (estas estão previstas em Anexo da Lei de Diretrizes Orçamentárias). Consequentemente, é possível uma melhor adequação entre as variáveis (despesas e metas fiscais) para que não se prossiga com a total incerteza acerca da execução das despesas discricionárias. Ou melhor, é necessário um ajuste entre esses elementos (despesas e metas fiscais), para que se evite a certeza de que as despesas discricionárias não serão executadas, a despeito de uma arrecadação razoavelmente próxima do que foi previsto.

\footnotetext{
${ }^{220}$ BRASIL. Secretaria do Tesouro Nacional. Metodologia de Cálculo do Superávit Primário. Disponível em http://www3.tesouro.fazenda.gov.br/hp/downloads/resultado/mnf_gv_central.pdf. Acesso em 31/05/2014.

${ }^{221}$ Ressalta-se que não foram utilizados dados que demonstrassem diretamente o resultado primário do governo, até porque o objetivo foi lançar um olhar sobre as despesas discricionárias, atingidas pelo contingenciamento, e não sobre o total de despesas.
} 
Novamente, embora os dados não demonstrem o superavit gerado em números ${ }^{222}$, eles demonstram que a administração pública federal arrecada próximo ao previsto (receitas) e fica muito longe do fixado quanto ao gasto (das despesas discricionárias). A repetição desse comportamento nos anos estudados evidencia problemas no planejamento, na transparência e no controle, temas aprofundados adiante. Mas não só. Em última instância, esses desajustes espelham a ampla possibilidade de inexecução de políticas públicas (ou adiamento ou parcial execução), ao passo que a obtenção de superavit primário continua como objetivo prioritário a ser alcançado (por vezes superado).

Não se pretende discutir a importância do superavit primário como indicador para a confiança da economia e para o controle da dívida. O que se destaca é a sua prevalência em detrimento das despesas discricionárias (que consolidam investimentos e políticas públicas) $)^{223}$.

Se os superavit primários são importantes para manter um equilíbrio na política fiscal e na relação entre dívida e PIB, de outro lado, significa que menos recursos estão sendo empregados na execução orçamentária dos demais órgãos e programas, ou seja, políticas públicas deixam de ser executadas e direitos deixam de ser concretizados. Há um conflito nas decisões orçamentárias, nem sempre claro nos processos democráticos, conforme coloca Élida Graziane Pinto ${ }^{224}$ :

Cumpre lembrar que a majoração dos gastos com o serviço da dívida, direta ou indiretamente, acarreta o contingenciamento de outras despesas, na medida em que faz contrair o montante disponível para executar as demais políticas públicas. Tudo isso é feito em nome de resultados fiscais primários positivos que garantiriam minimamente uma equação equilibrada entre o serviço da dívida e a possibilidade de sua expansão.

Mas como falar em processamento democrático e equilibrado da ampla competição por dotações orçamentárias que as políticas públicas travam entre si, se alguns dos motivos das oscilações no orçamento da União não são apresentados no curso dos processos discursivos que garantam o caráter público das decisões?

\footnotetext{
${ }^{222}$ Os dados apresentados não consideraram as despesas obrigatórias e despesas totais, razão pela qual não é possível afirmar que a diferença entre a receita arrecadada e despesa (discricionária) não executada correspondeu ao superávit primário. Aliás, a comparação está em termos percentuais. Para evidenciar o exato efeito do superávit, seria necessário uma análise em termos numéricos mais precisos e com outras variáveis em jogo. Esse não foi o objetivo. Buscou-se no trabalho focar na investigação de um comportamento problemático relativo ao gasto público.

${ }^{223}$ Certamente há aqui um elemento ideológico na escolha de maior ou menos superávit, maior ou menor déficit. Sobre o tema, vide ARVATE, Paulo Roberto. Instituições e resultados fiscais do governo federal. In BIDERMAN, Ciro; ARVATE, Paulo (orgs). Economia do Setor Público no Brasil. Rio de Janeiro: Elsevier, 2004. A partir de indicadores econômicos, o autor apresenta a influência da ideologia e da relação entre Executivo e Legislativo no resultado fiscal de países, incluindo o gasto do governo federal do Brasil.

${ }^{224}$ PINTO, Élida Graziane. Financiamento de Direitos Fundamentais: políticas públicas vinculadas, estabilização monetária e conflito distributivo no orçamento da União do pós-Plano Real. Belo Horizonte: Editora O Lutador, 2010, p. 21.
} 
Obviamente não se trata de uma discussão simples, porém, o que se nota é necessidade de alguns ajustes, especialmente porque, como dito, quando da elaboração e aprovação do orçamento federal, já estão previstas as metas fiscais (desde a LDO). Ou seja, quando se fixam as despesas discricionárias em um montante que nunca é executado , já se parte (ou se deveria partir) de uma meta fical.

Ao longo do exercício, o que se vê é que as despesas discricionárias são sempre consideravelmente inexecutadas, ao passo que as metas fiscais são alcançadas. Nos últimos anos, para o cumprimento das metas de resultado primário, é bem verdade, tem sido autorizada a dedução de despesas com o PAC (Programa de Aceleração do Crescimento), o que representa outro tipo de problema (criação de sub-orçamentos, já mencionada no capítulo anterior). Ainda que com essa autorização, estão sendo alcançadas as metas, conforme apontam os relatórios de Gestão Fiscal do TCU. No relatório para 2013, constou:

(...) o superávit primário da União teve meta reduzida para $\mathrm{R} \$ 73$ bilhões [dedução das despesas do PAC] e cumprida com folga de R \$ 1,7 bilhão. Entre os fatores que contribuíram para o alcance da meta reduzida, destacam-se: a limitação de empenho e movimentação financeira, também conhecida como contingenciamento, no valor de $\mathrm{R} \$ 24,7$ bilhões; a postergação de pagamento, via restos a pagar, de até $\mathrm{R} \$ 72,6$ bilhões; e as receitas atípicas de $\mathrm{R} \$ 46,3$ bilhões. ${ }^{225}$

Para 2012, foram feitas as mesmas observações e a conclusão foi que a "meta de superavit primário da União foi reduzida para R \$ 57,7 bilhões [dedução das despesas do PAC], e o seu cumprimento se deu com folga de R\$27,3 bilhões"226. Nesses dois anos, porém, houve sugestões do próprio TCU sugerindo melhoras na transparência e na metodologia do cálculo do resultado primário. Em 2011 e 2010 também houve cumprimento e superação das metas ${ }^{227}$.

\footnotetext{
${ }^{225}$ BRASIL, Tribunal de Contas da União. Relatório. Desempenho da Economia Brasileira. Gestão Fiscal. 2013. Disponível em http://portal2.tcu.gov.br/portal/page/portal/TCU/imprensa/noticias/noticias_arquivos/2_Desempenho\%20da \%20Economia\%20Brasileira\%20-\%20Gest\%C3\%A3o\%20Fiscal_web.pdf. Acesso em 03/06/2014.

${ }^{226}$ BRASIL, Tribunal de Contas da União. Relatório. Desempenho da Economia Brasileira. Gestão Fiscal. 2013. Disponível em http://portal2.tcu.gov.br/portal/page/portal/TCU/comunidades/contas/contas_governo/Contas2012/fichas/7.1 \%20-\%20Gest\%C3\%A3o\%20Fiscal_1.pdf. Acesso em 03/06/2014.

${ }^{227}$ Para 2011, conforme Anexo de Avaliação de Cumprimento das Metas do Ano anterior - 2011, o Governo Federal realizou superávit primário de $\mathrm{R} \$ 93,6$ bilhões no período de janeiro a dezembro de 2011, superando em $\quad \mathrm{R} \$ 1,9$ bilhão a meta do período". Disponível em http://www.planejamento.gov.br/secretarias/upload/Arquivos/sof/orcamento_13/Anexo_IV.2_Cumprimento_ Metas_Ano_Anterior.pdf. Acesso em 03/06/2014. Da mesma forma em 2010, conforme Avaliação de Cumprimento das Metas do Ano anterior - 2010, o superávit realizado pelo Governo Federal superou em R \$ 23,9 bilhões a meta estabelecida para o período. Disponível em
} 
Aliás, o cumprimento do superavit primário vem sendo alcançado desde anos anteriores, conforme dados de 1999 a 2005, apresentados por Élida Graziane Pinto, que conclui: "no período compreendido entre 2002 e 2005 repete-se tal fenômeno de contração fiscal acima das metas fiscais acordadas com o FMI - a partir do advento da LRF inscritas na LDO tal como dispõe o ar. $4^{\circ}$ da LC n. 101/2000"228.

Se, de um lado, o cumprimento reiterado dos resultados primários aponta para a existência de um Governo supostamente confiável na gestão da dívida, por outro lado, há um custo refletido nas políticas públicas, cuja gestão e execução não têm se mostrado transparente e planejada. Nessa linha, mais uma vez menciona-se Élida Graziane Pinto:

Considerando que o serviço da dívida líquida do setor público compõe o quadro das despesas orçamentárias e que, em torno de sua administração, são definidas e reformuladas várias políticas públicas, a discricionariedade de que goza o Executivo para administrar a dívida e, em especial, o financiamento de direitos fundamentais deve ser controlado diante dos casos concretos de remanejamento orçamentário. Não se questiona aqui o fato de que a dívida pública seja indiretamente utilizada como meio de absorção das disponibilidades financeiras no mercado e que essa seja uma estratégia de controle das pressões inflacionárias. O que não se pode perder de vista é que os juros que remuneram a dívida pública e a própria dívida são itens regulares do orçamento da União, ou seja, são despesas públicas que devem se ater aos limites legais e cuja motivação e finalidade podem, aliás, devem ser avaliadas desde o ponto de vista de sua conformidade com o texto constitucional vigente e com o preceito fundamental da máxima eficácia dos direitos fundamentais. ${ }^{229}$

Trata-se de preocupação que está diretamente relacionada ao contingenciamento, vez que é o principal mecanismo utilizado para se alcançar as metas fiscais. Aliada à obscuridade quanto aos critérios para o contingenciamento, tampouco há controle sobre o custeio do serviço da dívida (e consequentes reflexos no contingenciamento, desvinculações, aumento da carga tributária), especialmente "porque os gastos com o serviço da dívida não têm limite pré-determinado no ciclo orçamentário, podendo ser

http://www.planejamento.gov.br/secretarias/upload/Arquivos/sof/orcamento_13/Anexo_IV.2_Cumprimento_ Metas_Ano_Anterior.pdf. Acesso em 03/06/2014.

${ }_{228}$ PINTO, Élida Graziane. Financiamento de Direitos Fundamentais: políticas públicas vinculadas, estabilização monetária e conflito distributivo no orçamento da União do pós-Plano Real. Belo Horizonte: Editora O Lutador, 2010, p. 189.

${ }^{229}$ PINTO, Élida Graziane. Financiamento de Direitos Fundamentais: políticas públicas vinculadas, estabilização monetária e conflito distributivo no orçamento da União do pós-Plano Real. Belo Horizonte: Editora O Lutador, 2010, p. 21. 
expandidos discricionariamente, o debate jurídico político sobre o seu custo e sobre a origem dos recursos que lhe fazem frente não se abrem à sociedade"230.

Faz-se novamente a comparação: ao mesmo tempo em que o superavit primário é um importante indicador para o equilíbrio orçamentário e para o controle da dívida pública, não se pode, por outro lado, representar o objetivo máximo a ser buscado pelas finanças públicas, a qualquer custo, especialmente a partir das premissas da Constituição Federal de 1988, dentro de um novo paradigma do Direito Financeiro.

Nesse sentido, Fernando Facury Scaff, após constatar os efeitos do contingenciamentos na redução de gastos nas áreas da saúde e educação para antecipação de pagamentos de parcelas futuras dos juros e da dívida, afirma:

\begin{abstract}
Não se discute se o valor pago reduz ou não os juros da dívida e o grau de risco da economia brasileira. Discute-se que os Objetivos e os Fundamentos da República Brasileira estão sendo colocados em plano secundário pelos sucessivos governos brasileiros. Pagar a dívida pública é algo necessário, mas pagar a dívida futura como estratégia financeira em detrimento da melhoria das condições de vida da população, por certo não atende aos Objetivos estabelecidos na $\mathrm{Carta}^{231}$.
\end{abstract}

Ainda sobre o tema, Heleno Taveira Torres critica as formulações clássicas sobre o Direito Financeiro, no sentido de que não houve uma construção deste alinhado à Constituição Financeira do Estado Democrático de Direito instaurado com a Constituição de 1988. O mesmo autor exemplifica a partir do "mito do equilíbrio orçamentário, expressamente banido do texto constitucional desde a Emenda 1, de 1969, e não recepcionado pela Constituição de 1988, ao tempo que se presta como forte redutor da capacidade do Estado de realização dos objetivos constitucionais"232.

Há que se fazer uma ponderação entre essas escolhas, o que reclama uma interpretação menos rígida do equilíbrio orçamentário e do alcance das metas de superavit primário.

Nessa linha, válida a crítica de Fernando Facury Scaff e Francisco Sérgio Silva Rocha, no sentido de que o equilíbrio orçamentário não pode corresponder a uma "equação contábil-matemática com a finalidade de eliminar, sem um determinado critério, o déficit

\footnotetext{
${ }^{230}$ PINTO, Élida Graziane. Financiamento de Direitos Fundamentais: políticas públicas vinculadas, estabilização monetária e conflito distributivo no orçamento da União do pós-Plano Real. Belo Horizonte: Editora O Lutador, 2010, p. 25.

${ }^{231}$ SCAFF, Fernando Facury. Como a Sociedade Financia o Estado para a Implementação dos Direitos Humanos ?. In COUTINHO, Jacinto Nelson de Miranda; MORAIS, Jose Luis Bolzan de; STRECK, Lenio Luiz. (Org.). Estudos Constitucionais. São Paulo: Renovar, 2007, v. 1, p. 89.

${ }^{232}$ TORRES, Heleno Taveira. Teoria da Constituição Financeira. Tese apresentada ao Concurso de Títulos e Provas para o cargo de Professor Titular de Direito Financeiro. Faculdade de Direito da Universidade de São Paulo. São Paulo, 2014, p. 22.
} 
público". Deve-se, assim, considerar possível uma "política econômica que apresenta resultados destinados a superar momentos de crise ou o alcance de certas metas estabelecidas pela sociedade - tal como, no Brasil, a erradicação do analfabetismo" ${ }^{233}$. Por essa razão, o conceito de equilíbrio orçamentário deve estar relacionado à sustentabilidade financeira:

O conceito de equilíbrio orçamentário não pode ser entendido como uma camisa de força que obrigue os entes públicos a ter a mesma quantidade de receita e despesa, fechando estes números com plena identidade. Este conceito deve ser entendido como um dos muitos instrumentos de sustentabilidade financeira, de modo que o eventual desequilíbrio orçamentário anual seja uma ferramenta para o alcance de metas sociais democraticamente estabelecidas, sustentáveis a médio e longo prazo ${ }^{234}$.

A sujeição da execução orçamentária à rígida busca do superavit primário equivale, em parte, com o que parece ser uma tendência dos sistemas orçamentários contemporâneos, influenciados por uma determinada racionalidade econômica e, consequentemente, uma racionalidade de Estado, conforme aponta Nazaré da Costa Cabral. A autora fez uma retrospectiva sobre a evolução do pensamento econômico para verificar suas implicações nas finanças públicas e no papel intervencionista do Estado. Em seu estudo, busca demonstrar a influência decisiva da teoria das expectativas racionais para os sistemas orçamentais contemporâneos. Ao lado de outras, a teoria das expectativas racionais “ajudou a debilitação do keynesianismo nas economias de maior tradição liberal e ao ataque às tentações planificadoras que ele favorecera nas economias mistas do Ocidente" 235 . Dessa teoria decorreu "um enorme ceticismo em relação à eficácia da política de intervenção pública, a ideia de neutralidade das ações monetárias e financeiras”, as quais, por detrás, estão "centradas nos conceitos de credibilidade, consistência temporal e estabilidade" 236 .

${ }^{233}$ SCAFF, Fernando Facury; ROCHA, Francisco Sergio Silva. Equilíbrio Orçamentário e Sustentabilidade Financeira. In Revista dos Tribunais, vol. 925, p. 175, Nov/2012. Thomsom Reuters, 2012.

${ }^{234}$ Ibidem.

${ }^{235}$ CABRAL, Nazaré da Costa. Programa e decisão orçamental: da racionalidade das decisões orçamentais à racionalidade econômica. Coimbra: Almedina, 2008, p. 625.

${ }^{236}$ Conforme explica a autora, por trás dessa neutralidade, vislumbra-se uma outra face, de não-neutralidade: "pretenderiam os autores das expectativas racionais a mera definição, por parte dos policymakers, de um conjunto de regras estáveis, claras e bem conhecidas de todos, o que não andaria longe, ao fim e ao cabo, das regras de M. Friedman apontara, em 1948, à política governamental: $1^{a}$ fixação de uma taxa anual estável do aumento de massa monetária; $2^{a}$ fixação de uma taxa de despesas e de transferências governamentais que não varie em termos reais segundo o ciclo; $3^{a}$ fixação de taxas de fiscalidade estáveis, cujo objetivo no longo prazo seria o de equilibrar o orçamento do Estado. A partir desta aparente contraditoriedade ou ambiguidade entre as soluções de neutralidade/ não-neutralidade, é inaugurada uma nova etapa na história do pensamento econômico, como na da ação política: (...) um novo paradigma de política económica, caracterizada pela circunstância de ser tão necessária quanto minimalista e que irá (...) preocupar-se com o que sejam política antecipadas e não antecipadas e em cujo discurso abundará uma nova filosofia, centrada em conceitos muito 
Sem a pretensão de empreender críticas às teorias econômicas, o objetivo é apresentar suas influências para as decisões orçamentárias. O aspecto econômico (ou de política econômica) tem tido papel fundamental no orçamento.

No caso da racionalidade econômica advinda da prevalência da teoria das expectativas racionais, a consequência foi retirar a decisão que estava no "orçamentoplano" (há uma mitigação do planejamento) e a restituir ao mercado, especialmente em razão de três movimentos, destacados por Nazaré da Costa Cabral: reconhecimento das falhas do Estado (como mais perniciosas que as falhas de mercado), necessidade de reforma da gestão pública (substituindo o modelo burocrático pela lógica da gestão do setor privado) e elevação da credibilidade ao estatuto moral de modelo de comportamento aos próprios governos ${ }^{237}$.

No âmbito do Direito Financeiro, tal racionalidade teve influência decisiva na forma de encarar o orçamento, conforme explica a mesma autora:

De um lado, o orçamento vai abdicando da sua vocação ou predisposição
planeadora e decisional que tinha ostentado à luz dos sistemas integrados
e compreensivos de orçamentação. Por outro lado, o planeamento
econômico vai perdendo a importância e a força jurídica que lhe permita
determinar efetivamente o conteúdo do orçamento. (...) Na prática, resta
hoje pouco mais do que uma função informativa sobre as principais
opções em matéria política econômica e social de um dado Governo (...).
Isto resulta em uma certa desvitalização funcional do orçamento (...). O
orçamento torna-se um formato que incorpora decisões já tomadas, mas
nada decidindo, pelo menos nada que tenha grande relevância (nele se
contemplam apenas incrementos ou decrementos anuais $)^{238}$.

Em sentido semelhante, Gilberto Bercovici e Luís Fernando Massoneto descrevem que, em um primeiro momento, "a evolução do direito financeiro refletiu o protagonismo do Estado na organização do capitalismo no segundo pós-guerra, denotando integração progressiva entre a economia e as finanças públicas e legitimando a participação ativa do Estado no domínio econômico". Porém, esse quadro mudou nas últimas décadas do século XX com a contestação do padrão de financiamento público da economia. Consequentemente, "o paradigma constitucional que sustentara o Estado Social passou a ser frontalmente atacado, trazendo à tona questões que já pareciam superadas - a cisão

atraentes, como os da credibilidade, da consistência temporal e da estabilidade" (CABRAL, Nazaré da Costa. Programa e decisão orçamental: da racionalidade das decisões orçamentais à racionalidade econômica. Coimbra: Almedina, 2008, p. 331).

${ }^{237}$ CABRAL, Nazaré da Costa. Programa e decisão orçamental: da racionalidade das decisões orçamentais à racionalidade econômica. Coimbra: Almedina, 2008, p. 628.

${ }^{238}$ Ibidem, p. 573. 
entre economia e finanças públicas, a abstenção do Estado no domínio econômico e a pretensa neutralidade financeira propugnada pelos liberais" 239 .

Os mesmos autores também apontam que a mudança na atuação do Estado culminou em alterações no papel do Direito Financeiro. Ao passo que os orçamentos do Estado Social visavam fundamentalmente a garantia de direitos e a prestação de serviços públicos para a maioria da população; a partir dos anos 70 e 80, com a "financeirização do capitalismo" e a crise do setor público, o aumento dos gastos públicos passa a se relacionar com as despesas e com a política monetária, especialmente através de altas taxas de juros. Afirmam os mesmos autores que o déficit público para garantia do pleno emprego passa a ser o déficit público para a remuneração do capital:

Assim, nesta etapa, o direito financeiro, na organização do espaço político-econômico da acumulação, passa a servir a uma nova função do Estado - a tutela jurídica da renda, do capital e da sanção de ganhos financeiros privados, a partir da alocação de garantias estatais ao processo sistêmico de acumulação liderado pelo capital financeiro ${ }^{240}$.

Nesse ponto, tem-se a contraposição, de um lado, de uma perspectiva econômica do orçamento, submetido a uma racionalidade tal que lhe retirou a função de decidir, especialmente em questões extrafiscais (desvitalização funcional), reservando-lhe função meramente informativa ou, ainda, garantindo a remuneração do capital; de outro lado, está a perspectiva jurídica do orçamento, incorporado ao Estado Democrático de Direito e a um sistema de direitos fundamentais, cuja finalidade é dar efetividade à Constituição (mormente como instrumento de implementação desse Estado Democrático de Direito e dos direitos fundamentais).

Essas duas perspectivas entram em conflito em diversos momentos da execução e da elaboração orçamentária. Para ficar no contingenciamento, tal conflito se traduz na disputa entre a concretização dos direitos (que nada mais seria do que a maior execução do orçamento previsto) e o alcance ou superação das metas de superavit primário (rígido equilíbrio orçamentário).

Pelo que se tem apresentado, a face relacionada ao superavit primário tem se mantido firme às pressões pela concretização do Direito Financeiro, sendo fator primordial para o contingenciamento e a inexecução orçamentária. Bercovici e Mansueto falam em um impasse decorrente da "blindagem da Constituição Financeira e Agonia da

239 BERCOVICI, Gilberto; MASSONETTO, Luís Fernando. A Constituição Dirigente Invertida: A Blindagem da Constituição Financeira e a Agonia da Constituição Econômica. Boletim da Faculdade de Direito - Universidade de Coimbra. Suplemento. Coimbra, Portugal, v. XLIX, 2006, p. 59.

${ }^{240}$ Ibidem, p. 69. 
Constituição Econômica". Confirmando o que se está expondo, afirmam os autores que "a implementação da ordem econômica e da ordem social da Constituição de 1988 ficaram restritas, assim, às sobras orçamentárias e financeiras do Estado". Outros efeitos gerados ao gasto público são objeto do capítulo seguinte. 


\section{O CONTINGENCIAMENTO E OS EFEITOS NA EXECUÇÃO DO GASTO PÚBLICO}

\subsection{Considerações iniciais sobre os efeitos selecionados}

Pretendeu-se demonstrar no capítulo anterior que o contingenciamento tem sido um dos principais responsáveis pelos baixos percentuais de execução de despesas discricionárias do orçamento (proposto pelo Executivo e aprovado pelo Legislativo). Verificou-se que a inexecução do gasto público se dá em um grau muito superior à não realização das receitas. Ademais, o manejo dos gastos pelas seguidas reduções e ampliações dos limites de empenho e movimentação financeira nem sempre seguem as sugestões dos relatórios de avaliação bimestral e dificilmente se identifica proporcionalidade dentro dos órgãos do Poder Executivo.

A partir desse quadro, diversos problemas decorrentes da prática relativa ao contingenciamento poderiam ser suscitados. Selecionam-se quatro implicações, centrais à temática da concretização do Direito Constitucional Financeiro, considerando principalmente o seu "novo paradigma".

Em resumo, tem-se que a prática do contingenciamento tem trazido implicações negativas quanto (i) à realização de políticas públicas e consolidação dos direitos humanos; (ii) ao planejamento do gasto público; (iii) à transparência do gasto público; e (iv) à legitimidade democrática do gasto público.

No capítulo anterior, o foco foi nas implicações quantitativas na execução orçamentária. No presente capítulo, estudam-se as consequências "qualitativas" do contingenciamento. Em outras palavras, investiga-se em que medida o contingenciamento traz consequências negativas nesses diversos aspectos do gasto público (políticas públicas, planejamento, transparência e legitimidade). O objetivo é apontar os impactos não apenas em percentuais de inexecução e de disponibilização, mas os demais problemas por eles causados.

Antes de entrar em cada um dos temas escolhidos, de se apontar algumas notas sobre a escolha deles para análise do gasto público.

Em larga medida, a justificativa se confunde com alguns dos principais objetivos do Direito Financeiro, tal como explicitado no primeiro capítulo. Apontou-se que a concretização da Constituição Federal no âmbito do Direito Financeiro passa pela 
utilização do orçamento como mecanismo de implementação dos direitos sociais, pelo fortalecimento dos preceitos democráticos (garantindo transparência, legitimidade e controle do gasto público) e como meio de imprimir maior planejamento ao gasto.

A realização de políticas públicas é um dos meios pelo qual o Estado implementa os direitos humanos, especialmente os direitos sociais. Trata-se de objetivo e fundamento da própria Constituição Federal, conforme fixado no artigo $1^{\circ}$, quando prevê a dignidade humana como fundamento; e no artigo $3^{\circ}$, quando prevê como objetivo a construção de uma sociedade livre, justa e solidária, a erradicação da pobreza, a redução das desigualdades e a promoção do bem de todos. Tais objetivos se alcançam, dentre outros meios, pela execução do gasto público. Devem ser, portanto, preceitos observados pelo Direito Financeiro e pelos mecanismos de flexibilização orçamentária, dentre os quais o contingenciamento.

Nessa medida, se os índices de execução orçamentária (de despesas discricionárias) são muito baixos, haverá seguramente problemas na realização das políticas públicas e menor consolidação dos direitos sociais.

No tocante ao planejamento, embora esteja usualmente relacionado à elaboração das leis orçamentárias, especialmente dos planos plurianuais e da lei de diretrizes, e não propriamente à execução do gasto, é inegável que se na execução não se verifica minimamente o previsto nas leis, haverá uma frustração do planejamento. O planejamento de parte das despesas será inútil se não houver considerável execução. Basta pensar que o "planejamento de curto prazo", se é que assim se pode denominar a lei orçamentária anual, não tem sido observada.

As informações apresentadas apontam que é difícil se falar em qualquer planejamento de médio ou longo prazo se não há cumprimento da lei orçamentária, especialmente porque isso se verifica reiteradamente. Em outras palavras: se o previsto na lei orçamentária para um exercício é bastante desfigurado ao longo da execução, inclusive e principalmente pelo contingenciamento, isto significa que o planejamento não é respeitado. Assim, a conclusão é de que o contingenciamento influi também no planejamento, mais especificamente na sua implementação.

De se destacar, ainda, que o planejamento está positivado pelo Direito Financeiro, o que se extrai da necessidade de que a Lei Orçamentária Anual observe a Lei de Diretrizes 
Orçamentárias, a qual deve seguir o Plano Plurianual ${ }^{241}$. O próprio conteúdo que foi reservado a essas leis confirma o que se expõe.

Quanto à transparência, trata-se de critério cuja relevância tem sido reforçada por inovação de duas recentes leis: a Lei Complementar $n^{\circ} 131$, de 27 de maio de 2009, que modificou a Lei de Responsabilidade Fiscal no capítulo relativo à "transparência da gestão fiscal"; e a Lei de Acesso à Informação (Lei no 1.527, de 18 de novembro de 2011), que estabelece regras e procedimentos para garantir o acesso a informações, inclusive informações relativas às finanças públicas. São normas que demonstram a recente preocupação em se garantir maior transparência ao gasto público. Inegável que se configuram também objetivos já traçados na Constituição Federal (decorrente do princípio da publicidade e da previsão de acesso à informação) e também na Lei de Responsabilidade Fiscal, os quais agora se busca concretizar.

Ademais, a transparência relaciona-se ao tema tratado na medida em que, a partir do contingenciamento, impõe-se uma grande dificuldade no acompanhamento das despesas. Os seguidos "bloqueios" e "liberações" dos recursos, ampliações e reduções dos limites de movimentação e empenho, com critérios obscuros, impedem um acompanhamento mais preciso do gasto.

Por último, quanto à legitimidade democrática, se a Constituição Federal visa assegurar e aprofundar um regime democrático (conforme seu artigo $1^{\circ}$ ), é certo que a concretização do Direito Financeiro passa por um gasto público mais legítimo. Essa legitimidade se refere tanto à necessidade de uma participação mais efetiva do Legislativo, aspecto que já se discutia no "antigo paradigma" do Direito Financeiro, e também pela possibilidade de uma participação popular nas escolhas orçamentárias. Como conferir maior legitimidade democrática se, durante a execução, há profunda desconfiguração do orçamento aprovado pelo Legislativo? Como é possível o controle democrático, seja pelo Legislativo ou pelos cidadãos, se falta clareza quanto aos critérios de contingenciamento e liberação de recursos?

Ainda, importante mencionar que, ao menos em parte, os critérios selecionados se assemelham àqueles trazidos no Projeto de Lei do Senado $n^{\circ} 229$, de $2009^{242}$, que tramita

\footnotetext{
${ }^{241}$ Conforme Lei de Responsabilidade Fiscal, artigo 5: "O projeto de lei orçamentária anual, elaborado de forma compatível com o plano plurianual, com a lei de diretrizes orçamentárias e com as normas desta Lei Complementar (...)". Sobre o tema, vide ROCHA, Francisco Sérgio Silva. Orçamento e Planejamento: a relação de necessidade entre as normas do sistema orçamentário. In CONTI, José Maurício; SCAFF, Fernando Facury (coord.). Orçamentos Públicos e Direito Financeiro. São Paulo: Editora Revista dos Tribunais, 2011, pp. 729-749.
} 
no Congresso Nacional, e cujo objetivo é "fortalecer a gestão fiscal responsável", estabelecendo "normas gerais sobre plano, orçamento, controle e contabilidade pública, voltadas para a responsabilidade no processo orçamentário e na gestão financeira e patrimonial". Tal projeto foi denominado de Lei de Qualidade Fiscal.

Dentre as inovações propostas pelo projeto de lei em questão estão (i) o aperfeiçoamento do planejamento do gasto público (Título II), (ii) alterações das normas de transparência previstas na Lei de Responsabilidade Fiscal e (iii) o reforço da importância do Legislativo, com a obrigatoriedade de execução das emendas parlamentares (artigo 79). Veja-se que são três objetivos que se confundem com aqueles que se pretende aprofundar nesse estudo.

Conforme escreve Selene Peres Nunes, a ideia central da Lei de Qualidade Fiscal é “promover a qualidade do gasto público, com regras do tipo 'o que fazer e como`, ou seja, como atingir objetivos com o menor custo possível". Trata-se de função complementar à Lei de Responsabilidade Fiscal, mas com perspectiva diferente desta, "que trabalha com regras do tipo `não fazer`e está voltada para conter excessos de gastos e de dívida”243.

O projeto de lei traz algumas disposições acerca do contingenciamento, inclusive alterando o artigo $9^{\circ}$ da Lei de Responsabilidade Fiscal. Mais especificamente, o artigo 159 do PLS 229/09 dá nova redação ao artigo $9^{\circ}$ da Lei de Responsabilidade Fiscal, dispondo que a limitação de empenho será promovida pelos "titulares dos Poderes e órgãos autônomos de que trata o art. 20". O artigo 20 em referência lista, dentre os poderes, o Ministério Público, o Poder Legislativo, Poder Judiciário e a Defensoria Pública, além é claro do Poder Executivo ${ }^{244}$. Ao que consta, a nova redação visa tão somente esclarecer os

\footnotetext{
${ }^{242}$ BRASIL. Senado Federal. Projeto de Lei do Senado no 229, de 2009. Disponível em http://www.senado.gov.br/atividade/materia/detalhes.asp?p_cod_mate=91341. Acesso em 01/06/2013.

${ }^{243}$ NUNES, Selene Peres. Os 10 anos da LRF e o Projeto de Lei da Qualidade Fiscal. In Cadernos da Controladoria, Ano X, nº 02. Rio de Janeiro, 2010, p. 14. Disponível em http://www7.rio.rj.gov.br/cgm/comunicacao/publicacoes/cadernos/edicoes/2010_09/anexos/caderno_09_201 0.pdf. Acesso em 04/06/2013.

${ }^{244}$ Lei de Responsabilidade Fiscal (redação proposta pelo PLS 229):

“Artigo 20 (...)

$\S 2$ o Para efeito deste artigo, entende-se como órgão dotado de autonomia funcional-administrativofinanceira, na forma da Constituição Federal:

I - no Ministério Público:

a) o Conselho Nacional do Ministério Público;

b) o Ministério Público da União; e

c) os Ministérios Públicos dos Estados;

II- no Poder Legislativo:

a) Federal, as respectivas Casas e o Tribunal de Contas da União;

b) Estadual, a Assembléia Legislativa e os Tribunais de Contas;

c) do Distrito Federal, a Câmara Legislativa e o Tribunal de Contas

do Distrito Federal;

d) Municipal, a Câmara de Vereadores e o Tribunal de Contas do
} 
órgãos autônomos competentes para fazer contingenciamento de suas respectivas despesas, uma vez que a redação atualmente vigente já determina que a limitação de empenho seja efetuada pelos "Poderes e o Ministério Público".

As alterações mais relevantes, entretanto, estão nos artigos 78 e 79 do PLS 229/09. Tais artigos trazem especificações do que pode ou não ser contingenciado. Vale transcrever a norma:

Art. 78. Se for necessário efetuar a limitação de empenho e movimentação financeira de que trata $o$ art. $9^{\circ}$ da Lei Complementar $n^{\circ}$ 101, de 2000, o Poder Executivo apurará o montante necessário e informará a cada um dos órgãos referidos no art. 20 daquela lei, até o $20^{\circ}$ (vigésimo) dia após o encerramento do bimestre.

Parágrafo único. Não serão objeto de limitação de empenho e movimentação financeira, conforme o art. $9^{\circ}, \S 2^{\circ}$, da Lei Complementar $\mathrm{n}^{\circ} 101$, de 2000, as despesas:

I - relativas às obrigações constitucionais e legais do ente relacionadas em anexo da respectiva lei de diretrizes orçamentárias;

II - relacionadas como "Demais despesas ressalvadas" em Anexo da respectiva lei de diretrizes orçamentárias;

III - custeadas com recursos provenientes de doações e convênios; e

IV - constantes da lei orçamentária com o identificador de resultado primário.

Art. 79. No caso da União, as dotações incluídas na lei orçamentária por intermédio de emenda de bancada ou individual, nos limites indicados pelo art. 50, incisos I e II, desta Lei Complementar, devem ser obrigatoriamente executadas em sua totalidade durante o exercício financeiro.

$\S 1^{\circ}$ Caso se constate não ter havido a plena execução das dotações referidas no caput deste artigo, o balanço orçamentário da União deverá explicitar, caso a caso, as razões para o descumprimento deste artigo, admitidas apenas razões de ordem econômica, técnica ou ambiental.

$\S 2^{\circ}$ Caso o Tribunal de Contas da União considere que a razão alegada pelo Poder Executivo não justifica o descumprimento do disposto no caput deste artigo, o agente público responsável pela execução da despesa será pessoalmente responsabilizado, e passível de punição nos termos da lei orgânica do Tribunal de Contas da União.

O artigo 78 exclui das despesas contingenciáveis aquelas objeto de obrigações constitucionais e legais e outras despesas ressalvadas pela Lei de Diretrizes Orçamentárias, o que já estava previsto no $\S 2^{\circ}$ do artigo $9^{\circ}$ da Lei de Responsabilidade Fiscal. O que muda é que a norma inclui dentre as despesas não contingenciáveis aquelas custeadas com

Município, quando houver;

III - no Poder Judiciário:

a) Federal, os tribunais referidos no art. 92 da Constituição Federal;

b) Estadual, o Tribunal de Justiça e outros, quando houver;

IV - a Defensoria Pública Estadual.” 
recursos provenientes de doações e convênios e aquelas com identificador de resultado primário. Explica-se.

No tocante às despesas de convênio (inciso III do artigo 78), entende-se que o objetivo é impedir que esses valores, cuja finalidade é específica, sirvam para outra função ou não sejam executados para gerar superavit primário ${ }^{245}$.

Em relação ao não contingenciamento das despesas com identificador de resultado primário (inciso IV do artigo 78), entende-se que a norma visa proteger do contingenciamento o alcance das metas fiscais. Porém, não há clareza de quais despesas exatamente não poderiam ser contingenciadas. A própria definição de "identificador de resultado primário" não é suficiente para uma conclusão: "de caráter indicativo, tem como finalidade auxiliar a apuração do resultado primário previsto para o exercício (...) esse resultado é uma meta fiscal que avalia se o governo está gastando mais do que a arrecadação" 246 . Há diversos códigos para "identificador de resultado primário", o que se refere a despesas financeiras, o relativo a despesas obrigatórias ou também a despesas discricionárias $^{247}$, razão pela qual não é possível compreender com clareza o que de fato pretendeu a norma proposta.

O artigo 79, acima transcrito, por sua vez, pretende retirar das despesas contingenciáveis as dotações incluídas por emenda parlamentar. O projeto impõe que as despesas incluídas pelo Legislativo (emenda de bancada ou individual), dentro de determinados limites, sejam de execução obrigatória. Caso a norma seja descumprida, deve o Executivo explicitar as razões caso a caso, e o Tribunal de Contas da União apreciará as justificativas, podendo rejeitá-la e aplicar punições. Tal modificação é uma das formas de reforçar o papel do Poder Legislativo na execução do orçamento, o que busca garantir maior legitimidade ao gasto público, frente à concentração de poder no Executivo.

\footnotetext{
${ }^{245}$ Sobre a execução orçamentária dos convênios, menciona-se interessante "cartilha" elaborada pelo Tribunal de Contas da União: Brasil. Tribunal de Contas da União. Convênios e outros repasses. $4^{\mathrm{a}}$ Ed. Brasília: Secretaria-Geral de Controle Externo, 2013. Disponível em http://portal2.tcu.gov.br/portal/pls/portal/docs/2548956.PDF. Acesso em 04/06/2014.

${ }_{246}$ Conforme definido pelo Glossário do Portal do Orçamento. Disponível em http://www12.senado.gov.br/orcamento/glossario?b_start:int=60. Acesso em 04/06/2014

${ }^{247}$ Conforme Manual Técnico do Orçamento 2014, são as seguintes: (0) Financeira; (1) Primária e considerada na apuração do resultado primário para cumprimento da meta; (2) Primária e considerada na apuração do resultado primário para cumprimento da meta, sendo discricionária e não abrangida pelo PAC; (3) Primária e considerada na apuração do resultado primário para cumprimento da meta, sendo discricionária e abrangida pelo PAC; (4) Primária, constante do Orçamento de Investimento, e não considerada na apuração do resultado primário para cumprimento da meta, sendo discricionária e não abrangida pelo PAC; (5) Primária, constante do Orçamento de Investimento, e não considerada na apuração do resultado. (BRASIL. Ministério do Planejamento, Orçamento e Gestão. Secretaria de Orçamento Federal. Manual técnico de orçamento MTO. Edição 2014. Brasília, 2013, p. 71. Disponível em http://www.orcamentofederal.gov.br/informacoes-orcamentarias/manual-tecnico/MTO_2014.pdf. Acesso em 04/06/2014).
} 
Ainda sobre as alterações propostas pelo PLS 229/09, tem-se a inclusão no Decreto-lei no 2.848, do artigo 359-I, que prevê pena de reclusão, de 1 a 2 anos, e multa, para o titular do Poder ou órgão autônomo que "deixar de ordenar ou de promover, na forma e nos prazos previstos em lei, a limitação de empenho e movimentação financeira, no âmbito do respectivo Poder ou órgão autônomo, nos termos fixados na lei complementar e na lei de diretrizes orçamentárias".

Propõe-se pena de reclusão para o gestor público que não proceder ao contingenciamento de despesas quando deveria, levando-se ao âmbito criminal o alcance das metas fiscais. Há aqui certo exagero, vez que, se já há enorme dificuldades na avaliação do contingenciamento no âmbito dos órgãos especializados (Tribunal de Contas e controladorias), que raramente procedem a apreciações rígidas sobre o contingenciamento, o que dirá levar essa avaliação ao âmbito criminal.

Feitas as observações, retornando às justificativas para os itens selecionados, o que se quer apontar é que parte das alterações propostas pela "Lei da Qualidade Fiscal" está relacionada com os princípios e preceitos constitucionais de Direito Financeiro que aqui se estuda: princípio da transparência, planejamento e legitimidade democrática.

Por fim, também como justificativa, tem-se que os itens selecionados são recorrentemente relacionados pela doutrina ao contingenciamento, como será verificado ao longo do presente capítulo. Passa-se, então, a analisar cada um dos temas e sua relação com o contingenciamento.

\subsection{Os efeitos do contingenciamento na realização das políticas públicas e na consolidação dos direitos sociais}

Iniciou-se o presente trabalho mencionando-se o extenso rol de direitos consignados na Constituição Federal, dentre os quais estão não apenas liberdades individuais, mas também direitos sociais que, via de regra, exigem prestações positivas por parte do Estado. É por isso que o ordenamento jurídico nacional incorpora uma concepção do Direito não apenas como garantidor das liberdades individuais, mas também como implementador de políticas públicas, como escreve Fernando Facury Scaff ${ }^{248}$.

Por exigir uma atuação positiva do Estado, o que se dá via realização de políticas públicas, os direitos (especialmente os sociais) necessitam do emprego de recursos

248 SCAFF, Fernando Facury. Constituição Econômica Brasileira em seus 15 anos. Revista de Direito Público da Economia - RDPE, Belo Horizonte, v. 3, jul / set, 2003, p. 62 
públicos. Como afirmam Stephen Holmes e Cass Sustein, tanto direitos de $1^{\mathrm{a}}$ geração (como a liberdade), quanto direitos de $2^{\mathrm{a}}$ e $3^{\mathrm{a}}$ geração (como seriam os direitos sociais e econômicos) não podem ser protegidos sem gasto público - "os direitos custam dinheiro" 249 .

A própria Constituição Federal de 1988 (por vezes com a complementação do constituinte reformador) leva em consideração o "aspecto financeiro" dos direitos sociais, prevendo ela mecanismos de custeio. Mencionam-se os já referidos gastos mínimos com saúde e educação ${ }^{250}$ (implementados em sua maioria via vinculação de receitas a fundos). Cita-se também a previsão de contribuições sociais com arrecadação destinada à seguridade social $^{251}$. Tais aspectos não deixam dúvidas que a consolidação desses direitos depende da concretização do gasto público. É preciso que as mais diversas políticas públicas previstas cheguem à fase final do gasto.

$\mathrm{Na}$ análise que se tem feito, percebeu-se um grave problema na execução de parte dessas políticas públicas. Há mera previsão de políticas, sem a real possibilidade de que sejam realizadas, dados os elevados impactos do contingenciamento e os altos percentuais de inexecução de despesas discricionárias.

Os dados apresentados no capítulo anterior já possibilitariam essa conclusão. Ou seja, se os Ministérios não executam boa parte das despesas autorizadas (especialmente as discricionárias), é certo que diversos programas não são realizados.

Para ilustrar os efeitos sobre as políticas públicas, coloca-se uma lupa sobre alguns programas, demonstrando a gravidade da situação relativamente aos direitos sociais. Basta passar pelas planilhas de "Execução de despesas por função" 252 para se verificar que diversos programas ficam, em larga medida, inexecutados. Citam-se alguns exemplos relativos aos anos analisados neste trabalho (2010 a 2013) $)^{253}$.

Na função "Educação", o programa de "Enfrentamento da violência sexual contra crianças e adolescentes" (cod. 0073) teve uma dotação autorizada, em 2010, de R\$

\footnotetext{
${ }^{249}$ HOLMES, Stephen; SUNSTEIN, Cass R. The Cost of Rights - why liberty depend on taxes. New York: W.W.Norton \& Company, 1999, p. 15.

250 Artigo 212 da Constituição Federal c/c artigo 60, VIII do Ato das Disposições Constitucionais Transitórias (educação). Artigo 198, §§ $1^{\circ}, 2^{\circ}$ e $3^{\circ}$, da Constituição Federal (saúde).

${ }^{251}$ Artigo 195 da Constituição Federal.

252 Trata-se das planilhas de "Despesa Execução - por função", a qual pode corresponder à função "Educação", "Habitação”, "Indústria”, "Gestão Ambiental”, "Assistência Social”, "Defesa nacional”, dentre outras. Obtida no Portal do Orçamento. Disponível em http://www12.senado.gov.br/orcamento/loa. Acesso em 17/03/2014.

${ }^{253}$ A título exemplificativo, escolheram-se algumas funções em que se verificou a inexecução relevante, sendo certo que, pelos próprios dados gerais apresentados no capítulo anterior, trata-se esta de situação bastante comum na execução de despesas discricionárias.
} 
8.000.000,00, do qual apenas $\mathrm{R} \$ 2.207 .154,00$ foi liquidado, e apenas $\mathrm{R} \$ 899.845,00$ foi pago. Ou seja, do total, $27 \%$ foi liquidado e $11 \%$ pago. No ano seguinte, dos $\mathrm{R} \$$ 7.073.000,00 autorizados (conforme soma dos diversos subcódigos), somente R\$ 692.887,00 foram liquidados (9\% do autorizado) e $\mathrm{R} \$ 571.660,00$ foram pagos (8\% do autorizado). Em 2012 e 2013, não houve previsão de valores para tal programa.

Na função "Habitação", o programa de "Habitação de Interesse Social" (cod. 9991), teve em $2010 \mathrm{R} \$ 209.194 .702,00$ autorizados, porém, liquidou-se $43 \%$ disso (R\$ 91.557.575,00) e pagou-se apenas 7\% do autorizado ( $\mathrm{R} \$ 14.963 .194,00)$. Apesar da inexecução, em 2011, aumentou-se a despesa autorizada (passou para $\mathrm{R} \$ 285.673 .333,00$ ), mas em termos percentuais foi liquidado ainda menos, $41 \%$ ( $\mathrm{R} \$ 119.951 .254,00)$, e pagouse muito pouco: $\mathrm{R} \$ 12.266 .697,00$ (4\% do autorizado). Em 2012, a informação é de que não houve dotação para esse programa. E em 2013, foram pagos R 32.201.334.00 relativos a Restos a pagar.

Ressalta-se que o objetivo aqui é ilustrar os efeitos do contingenciamento e da inexecução orçamentária sobre as políticas públicas. O mesmo exercício foi feito por Eduardo Bastos Furtado de Mendonça, que apontou alguns programas previstos no orçamento, mas sem efetiva aplicação de recursos (ou com recursos insuficientes) ${ }^{254}$. É o que também fez Michel Haber Neto em relação ao direito à saúde. Vale mencionar as críticas deste autor sobre a prevalência dada ao pagamento da dívida, em detrimento da realização de políticas públicas no âmbito dos direitos sociais:

Vislumbra-se uma evidente inversão valorativa, pelo que: deixa-se a
implementação de políticas públicas voltadas à efetivação da saúde
pública à mercê da discricionariedade do Poder Executivo, que poderá,
mediante decreto, reter recursos destinados a este mister; mas o impede
de fazer o mesmo no que tange a cortes no pagamento do serviço da
dívida. Faz-se tábula rasa dos objetivos, prescritos nos incisos do artigo
$3^{\circ}$ da CF, e que devem ser perseguidos pela administração pública ${ }^{255}$.

Interessante apontar, ainda, a análise feita pelo mesmo autor acerca dos efeitos do contingenciamento sobre os gastos com saúde no ano de 2012. Conforme ele bem observa, o Decreto de contingenciamento em 2012 (Decreto $n^{\circ}$. 7.680/2012) "reteve" verbas destinadas à saúde em patamar que acabou por violar os gastos mínimos obrigatórias na área (conforme determinação da Lei Complementar $n^{\circ}$ 141/2012). A conclusão do autor

\footnotetext{
${ }^{254}$ MENDONÇA, Eduardo Bastos Furtado de. Constitucionalização das Finanças Públicas no Brasil. Rio de Janeiro: Renovar, 2010, p. 94.

${ }^{255}$ HABER NETO, Michel. A tributação e o financiamento do direito à saúde no Brasil. Dissertação de Mestrado em Direito. Faculdade de Direito da Universidade de São Paulo. São Paulo, 2012, p. 203.
} 
não poderia ser outra: “o Decreto de Contingenciamento viola a garantia constitucional do orçamento mínimo da saúde, pelo que não observa os gastos mínimos a serem realizados pela União Federal no exercício financeiro de 2012,256.

Problema semelhante foi constatado por Fernando Facury Scaff relativamente ao orçamento mínimo da educação (limite mínimo de aplicação de recursos na erradicação do analfabetismo e na manutenção e no desenvolvimento do ensino fundamental) do ano de 2005. A partir de Relatório do Tribunal de Contas da União, o autor verifica que que o contingenciamento afetou diretamente recursos que deveriam ser destinados à educação (dentre outras áreas), sem posterior recomposição dos empenhos originalmente previstos $^{257}$. Consequentemente, houve uma violação à norma constitucional que garante o orçamento mínino para a educação (artigo 212 da Constituição Federal).

Tem-se, assim, um grave problema gerado pelo contingenciamento relativamente à realização de políticas públicas. Se os direitos para os quais a Constituição prevê um "orçamento mínimo" sofrem com o contingenciamento, imagina-se quadro muito pior para os demais. É bastante comum verificar programas sem qualquer execução ou com execução de apenas metade do autorizado ou, ainda, com execução somente de restos a pagar. Trata-se de situação bastante prejudicial não só para a consolidação dos direitos, mas também para a transparência e legitimidade democrática do gasto público.

Como se disse, a consolidação de direitos implica na utilização de recursos (“direitos custam”). O que se demonstra é que a mera previsão desses direitos (ou de programas a eles relativos) no orçamento significa somente um pequeno passo rumo a sua concretização. O que de fato importa é o momento da execução orçamentária, no qual muitos programas ficam pelo caminho. Trata-se de situação que pode ser constatada tanto em órgãos menos afetados pelo contingenciamento e pela inexecução, como a Educação, e será muito mais grave em órgãos mais afetados pela inexecução, a exemplo de Turismo, Esporte e Cidades ${ }^{258}$.

Há muito a se avançar, portanto, na realização de políticas públicas para que direitos previstos se tornem direitos titularizados e, embora esse seja um claro objetivo da Constituição Federal de 1988, enfrenta-se o dilema entre as pretensões jurídico-

\footnotetext{
${ }^{256}$ Ibidem, p. 205.

257 SCAFF, Fernando Facury. Como a Sociedade Financia o Estado para a Implementação dos Direitos Humanos?. In COUTINHO, Jacinto Nelson de Miranda; MORAIS, Jose Luis Bolzan de; STRECK, Lenio Luiz. (Org.). Estudos Constitucionais. São Paulo: Renovar, 2007, v. 1, p. 88.

${ }^{258}$ Considerando as médias de 2010 a 2013 relativas ao percentual executado de despesas discricionárias (segundo critério do SIAFI), o Ministério da Educação está entre os cinco menos afetados (com percentual de $61 \%$ ). Dentre os mais afetados, estão Turismo e Esporte com 16\% cada; e Cidades com $23 \%$.
} 
constitucionais e as pressões econômico-políticas. Com pontuam Gilberto Bercovici e Luís Fernando Massoneto, “a constituição dirigente das políticas públicas e dos direitos sociais é entendida como prejudicial aos interesses do país, causadora última das crises econômicas, do déficit público e da ingovernabilidade". De outro lado, "políticas neoliberais de ajuste fiscal", visando garantir credibilidade e confiança perante o mercado financeiro internacional vincula toda a política brasileira, representando, assim, uma “constituição dirigente invertida" 259 .

\subsection{Os efeitos do contingenciamento no planejamento do gasto público}

O planejamento do gasto público está expressamente positivado no ordenamento jurídico brasileiro na Lei de Responsabilidade Fiscal que, ao definir gestão fiscal responsável, inclui o planejamento como um de seus pressupostos ${ }^{260}$.

Ademais, o processo orçamentário nacional, previsto constitucionalmente, é composto por três leis: o Plano Plurianual (PPA), com diretrizes, objetivos e metas da administração pública federal para as despesas de médio e longo prazo; a Lei de Diretrizes Orçamentárias (LDO), com metas e prioridades da para o exercício financeiro subsequente, e, finalmente, a Lei Orçamentária Anual, que fixa as despesas para o exercício financeiro seguinte.

A própria previsão de três leis orçamentárias explicita a necessidade de que o gasto público seja planejado. Observa-se, ainda, que a compatibilidade da LOA com o PPA e a LDO é determinação expressa do artigo $5^{\circ}$ da Lei de Responsabilidade Fiscal ${ }^{261}$.

O planejamento é, assim, não mero capricho constitucional, mas determinação a ser cumprida pelo legislador e pelo executor do orçamento. É certo que planejar os gastos no âmbito público não é tarefa fácil. Há tempos, enfrentam-se dificuldades na sua implementação.

259 BERCOVICI, Gilberto; MASSONETTO, Luís Fernando. A Constituição Dirigente Invertida: A Blindagem da Constituição Financeira e a Agonia da Constituição Econômica. Boletim da Faculdade de Direito - Universidade de Coimbra. Suplemento. Coimbra, Portugal, v. XLIX, 2006, p. 73.

260 “Art. $1^{\circ}, \S 1^{\circ} \mathrm{A}$ responsabilidade na gestão fiscal pressupõe a ação planejada e transparente, em que se previnem riscos e corrigem desvios capazes de afetar o equilíbrio das contas públicas, mediante o cumprimento de metas de resultados entre receitas e despesas e a obediência a limites e condições no que tange a renúncia de receita, geração de despesas com pessoal, da seguridade social e outras, dívidas consolidada e mobiliária, operações de crédito, inclusive por antecipação de receita, concessão de garantia e inscrição em Restos a Pagar".

261 "Art. $5^{\circ} \mathrm{O}$ projeto de lei orçamentária anual, elaborado de forma compatível com o plano plurianual, com a lei de diretrizes orçamentárias e com as normas desta Lei Complementar (...)". 
O planejamento previsto na Constituição Federal de 1988 é fruto de uma evolução das técnicas de elaboração orçamentária no Brasil, cujo início se deu com a criação do DASP (Departamento Administrativo de Serviço Público) em 1938, seguindo-se pela elaboração de diversos "planos de investimento governamental de longo prazo, como o Plano Especial de Obras Públicas e Aparelhamento da Defesa Nacional (1939), o Plano de Obras e Equipamentos (1943), o Plano SALTE (Saúde, Alimentação, Transporte e Energia - 1950) e o Programa de Metas (1956), dentre outros"262.

A dificuldade na consolidação de um gasto público planejado é também tema de intensa discussão doutrinária. E os problemas práticos não são poucos. Marcos José Mendes aponta que a racionalidade dessa sistemática, no qual a LOA representaria um desdobramento natural de um planejamento que se inicia com o PPA e passa pela LDO, acaba sendo distorcida, de forma que a execução do Orçamento, e não o planejamento, é onde se concentram os interesses do sistema político: "isso transformou o PPA em uma formalidade legal (...) e que tem pouca aplicabilidade prática e limitada influência na realidade ${ }^{, 263}$. Para o mesmo autor, há um foco no curto prazo, decorrente, dentre outras razões, de um regime político em que o Poder Executivo tem dificuldade para formar maioria no Congresso ${ }^{264}$.

As referidas críticas estão intrinsecamente relacionadas ao objeto deste trabalho. São problemas para o planejamento: a execução orçamentária sempre parcial, alterada pelo Executivo de forma unilateral e substancial, com concentração de liberação de recursos no final do exercício e sem critérios que permitam aferir se haverá dinheiro suficiente para a execução dos programas planejados.

Conforme dados apontados no capítulo anterior (ver Tabela 18 - Evolução dos percentuais de execução, empenho e pagamento das despesas discricionárias do Executivo nos anos de 2010 a 2013), com relação às despesas discricionárias, executou-se, entre 2010 e 2013 , em média, apenas $56 \%$ do que foi autorizado na lei orçamentária (somados os créditos adicionais). Como estabelecer um planejamento se quase metade (ou por vezes menos do que isso) do que foi "planejado" não é simplesmente cumprido ou, então, é adiado para anos posteriores?

\footnotetext{
${ }^{262}$ CONTI, José Maurício. Planejamento e Responsabilidade Fiscal. In SCAFF, Fernando Facury; CONTI, José Maurício. Lei de Responsabilidade Fiscal - 10 anos de Vigência - Questões Atuais. Florianópolis: Conceito Editorial, 2010, p. 42.

${ }^{263}$ MENDES, Marcos J. Sistema orçamentário brasileiro: planejamento, equilíbrio fiscal e qualidade do gasto público. Texto para discussão 39. Brasília: Consultoria Legislativa do Senado Federal, 2008, p. 10 ${ }^{264}$ Ibidem, p. 42.
} 
A análise foi feita com base nas despesas discricionárias, as quais contemplam grande parte dos investimentos. Daí a conclusão de que há enorme dificuldade em conduzir os investimentos nos níveis planejados. Como aponta Carlos Otávio Ferreira de Almeida, a utilização "excessiva" do contingenciamento compromete o planejamento das ações públicas "em especial por congelar, prioritariamente, despesas de investimentos, o que emperra o desenvolvimento (...) e por decorrência, há um enfraquecimento do PPA"265.

A situação é pior se o foco são Ministérios com execução muito abaixo da média, a exemplo do Ministério do Turismo e do Ministério do Esporte, que mostraram as piores médias de percentual executado (metodologia oficial) de despesas discricionárias nos últimos quatro anos: apenas $16 \%$ do autorizado. Impossível cogitar qualquer planejamento com percentuais tão baixos.

A mesma constatação foi feita por Élida Graziane Pinto, que questiona: “como pode haver limitação das ações de todo um Ministério da ordem de $80 \%$ dos recursos originalmente estipulados pela LOA para o mesmo?"266.

Outro problema relativo ao planejamento é a obscuridade de critérios para a retomada da execução orçamentária ao longo do exercício. Internamente ao Poder Executivo (entre as suas unidades orçamentárias) não se obedece a proporcionalidade em relação ao que foi limitado (conforme deveria ocorrer segundo o disposto no $\S 1^{\circ}$ do artigo $9^{\circ}$ da Lei de Responsabilidade Fiscal). Basta olhar para os comportamentos ilustrados nos decretos de contingenciamento editados ao longo do ano (conforme tabelas 1, 5, 9 e 13).

Toma-se como exemplo o ano de 2010, no qual os percentuais foram alterados por duas vezes (vide tabela 1). Embora do primeiro para o segundo decreto ampliou-se o contingenciamento, ou seja, diminuiu-se o disponível total, cada Ministério sofreu um comportamento distinto. Alguns se mantiveram estáveis, a exemplo do Ministério das Relações Exteriores. Em outros, aumentaram-se significativamente os recursos disponíveis, a exemplo do Ministério do Turismo (de 15\% para 28\%). Em outros, houve diminuições relevantes do disponível, a exemplo do Ministério da Fazenda, que foi de 85\% para $60 \%$ dos recursos disponíveis.

\footnotetext{
${ }^{265}$ ALMEIDA. Carlos Otávio Ferreira de. Planejamento Financeiro Responsável. In CONTI, José Maurício; SCAFF, Fernando Facury (coord.). Orçamentos Públicos e Direito Financeiro. São Paulo: Editora Revista dos Tribunais, 2011, p. 587.

266 PINTO, Élida Graziane. Financiamento de Direitos Fundamentais: políticas públicas vinculadas, estabilização monetária e conflito distributivo no orçamento da União do pós-Plano Real. Belo Horizonte: Editora O Lutador, 2010, p. 311.
} 
Desta forma, se não há como se prever se o órgão será contemplado com a "liberação" ou o "bloqueio" de recursos ao longo do ano, impossível se concretizar qualquer tipo de planejamento, nem mesmo no curto espaço de um exercício.

Nessa linha a crítica de Selene Peres Nunes que afirma: após todos os esforços de planejamento da elaboração das leis orçamentárias, surge, na fase de execução, o contingenciamento, "feito por órgão, institucionalmente, atendendo à lógica de cada ministro, de cada órgão; ele não é feito por programa e ação, o que já joga fora outra parte do planejamento; perde-se todo o esforço que foi feito na definição de prioridades por programas e ações" ${ }^{267}$. Segundo a autora, o contingenciamento não deveria ser por órgão (“institucional"), mas por programa, pela seguinte razão: "Se toda a despesa foi estruturada por programa, lá no PPA, por que se quebra a lógica no meio do caminho e se faz o contingenciamento institucional?"268.

É preciso destacar que os equívocos e as dificuldades do planejamento não são culpa exclusiva do contingenciamento. O contingenciamento também é resultado da ausência de um planejamento adequado e que acaba por intensificar sua utilização.

É preciso que se façam previsões mais adequadas de receita, avaliações mais rigorosas para créditos adicionais e para a inclusão de novas dotações no orçamento do exercício seguinte, além de se estabelecer critérios de prioridades para programas ou obras com execução iniciada, para que não fiquem pelo caminho por anos seguidos ${ }^{269}$.

Nesse sentido, tratando dos efeitos do contingenciamento, o economista Alexandre Schwartsman classifica o orçamento como uma "obra (ruim) de ficção", que já "chega inflado ao Congresso, que trata de inchá-lo um pouco mais, seja do lado das despesas, seja do lado da receita". Por tais razões, é apenas com o decreto de contingenciamento e programação que se estabelece de fato o que o governo pretende fazer, inclusive com "corte" de gastos. Porém, conclui o economista, o orçamento "corta vento", pois são

\footnotetext{
${ }^{267}$ NUNES, Selene Peres. Os 10 anos da LRF e o Projeto de Lei da Qualidade Fiscal. In Cadernos da Controladoria, Ano X, $\mathrm{n}^{\mathrm{o}}$ 02. Rio de Janeiro, 2010, p. 25. Disponível em http://www7.rio.rj.gov.br/cgm/comunicacao/publicacoes/cadernos/edicoes/2010_09/anexos/caderno_09_201 0.pdf. Acesso em 04/06/2013.

${ }^{268}$ Ibidem, p. 40.

${ }^{269}$ Propostas de incremento do planejamento do gasto público são feitas por NUNES, Selene Peres. Os 10 anos da LRF e o Projeto de Lei da Qualidade Fiscal. In Cadernos da Controladoria, Ano X, $\mathrm{n}^{\circ}$ 02. Rio de Janeiro, 2010. Disponível http://www7.rio.rj.gov.br/cgm/comunicacao/publicacoes/cadernos/edicoes/2010_09/anexos/caderno_09_201 0.pdf. Acesso em 04/06/2013.
} 
"gastos que existiam apenas no fantasioso mundo do Orçamento federal" 270 . Sem entrar na discussão político-econômica sobre a necessidade de cortar gastos, o fato é que há razão em se afirmar que, do ponto de vista prático, não há mínima expectativa de que os valores previstos no orçamento federal serão executados (ao menos quanto às despesas discricionárias). De fato, em larga medida, o orçamento funciona como uma mera peça de ficção, o que demonstra a fragilidade do planejamento.

Outra consequência da ausência de planejamento adequado, instrumentalizada e acirrada pelos reiterados e imotivados contingenciamentos, é o aumento de restos a pagar. Fica ainda mais difícil fazer um planejamento com uma grande quantidade de restos a pagar. Explica-se.

Com objetivo de garantir o resultado primário, posterga-se o pagamento de despesas para o ano seguinte, inscrevendo-se despesas em restos a pagar. Consequentemente, o planejamento do ano seguinte já começa afetado por despesas de anos anteriores, de programas anteriores e assim sucessivamente: “a inscrição 'abusiva' de Restos a Pagar implica a acumulação de obrigações em volume superior à real capacidade de pagamento. Assim, comprometem-se as receitas futuras com obrigações de orçamentos pretéritos e imobilizam o governo quanto ao orçamento corrente no início de cada

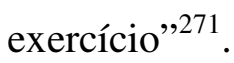

É ainda pior quando a inscrição de valores em restos a pagar é decorrente do receio do gestor público em perder recursos para o próximo ano. Sobre o tema, Gustavo Alves verifica que os contingenciamentos antecipados culminam em uma autorização tardia para o empenho e pagamento das despesas, fazendo com que o gestor, sem tempo para concretizar as despesas, inscreva-as como restos a pagar, "para não perder a dotação orçamentária e, ressalta-se, para não diminuir a base de cálculo de despesas que pauta a proposta orçamentária para o próximo exercício, num contexto de incrementalismo

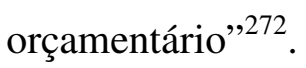

Essa é outra implicação dos reiterados contingenciamentos: a "retenção" dos recursos durante o exercício e a liberação apenas no final do ano, após a certeza do cumprimento das metas. Tal procedimento, segundo Carlos Otávio Ferreira de Almeida,

\footnotetext{
${ }^{270}$ SCHWARTSMAN, Alexandre. $O$ orçamento e o vento. Folha de São Paulo. Artigo disponível em http://www1.folha.uol.com.br/colunas/alexandreschwartsman/2014/02/1417921-o-orcamento-e-ovento.shtml. Acesso em 12/03/2014.

${ }^{271}$ ALVES, Gustavo Henrique Tardelli. O orçamento federal entre a realidade e a ficção: as armadilhas à transparência da despesa pública no Brasil. Monografia (especialização Curso de Orçamento Público). Instituto Serzedello Corrêa (ISC), 2012, p. 40.

${ }^{272}$ Ibidem, p. 39.
} 
"leva a sérias dúvidas quanto à qualidade do gasto e à observância do planejamento orçamentário, ensejando licitações aceleradas a preços oportunamente elevados pelos fornecedores" ${ }^{273}$. E, como já observado, quando não há tempo de efetuar o pagamento do gasto, haverá também inscrição de valores em restos a pagar, contribuindo para a acumulação de obrigações de anos anteriores que devem ser quitadas no ano posterior.

Sobre esse mesmo aspecto, Mansueto Almeida, Alexandre Manoel e Helder Rebouças destacam que, quando as previsões de receitas e despesas são "equivocadas" ou "inconsistentes", o contingenciamento "acaba postergando para muito próximo do final do ano a efetiva liberação de recursos, para que as unidades orçamentárias empenhem, liquidem e paguem as despesas orçadas". Surgem, então, os restos a pagar, decorrentes justamente da ausência de tempo hábil para executar várias dessas despesas ${ }^{274}$. Como já colocado, os restos a pagar concorrem com as despesas planejadas para o ano seguinte.

Observam os citados autores, economistas do IPEA, outra consequência danosa, qual seja, o aumento do endividamente para quitação dos restos a pagar. Endivida-se para pagar despesas de anos anteriores. Cria-se, então, um verdadeiro círculo vicioso, já que o incremento da dívida pressionará "o governo a obter mais superavit primário, inclusive por meio de novos contingenciamentos" $" 275$. Por sua vez, esses contingenciamentos aumentam os restos a pagar, obrigando o governo a se endividar e assim suscessivamente. Sem que haja ajustes na utilização do contingenciamento, tal círculo certamente impedirá avanços no planejamento.

Portanto, embora o planejamento esteja usualmente relacionado ao processo de elaboração da lei orçamentária, é essencial que também se discutam mudanças na execução, tendo em vista a forma como ela tem sido conduzida no âmbito federal. Uma aplicação do contingenciamento dentro de seus parâmetros legais e com maior explicitação dos critérios com que os recursos são limitados ou disponibilizados (inclusive dentro do Poder Executivo) contribuiria para melhorar o planejamento.

Se a aplicação do contingenciamento se aproximar do que previsto em lei, do “dever ser”, pode-se melhorar, inclusive, a elaboração da lei orçamentária.

\footnotetext{
273 ALMEIDA. Carlos Otávio Ferreira de. Planejamento Financeiro Responsável. In CONTI, José Maurício; SCAFF, Fernando Facury (coord.). Orçamentos Públicos e Direito Financeiro. São Paulo: Editora Revista dos Tribunais, 2011, p. 587

274 ALMEIDA, Mansueto; MANOEL, Alexandre; REBOUÇAS, Helder. "Os impasses do contingenciamento". Valor Econômico. São Paulo, 02 de março de 2012. Disponível em http://www.senado.gov.br/noticias/opiniaopublica/inc/senamidia/notSenamidia.asp?ud=20120302\&datNotici $\mathrm{a}=20120302 \& \operatorname{codNoticia}=663311 \&$ nomeOrgao $=\&$ nomeJornal $=$ Valor + Econ $\% \mathrm{C} 3 \% \mathrm{~B} 4 \operatorname{mico} \& \operatorname{codOrgaO}=272$ 9\&tipPagina=1. Acesso em 12/03/2014.

${ }^{275}$ Ibidem.
} 
Como coloca Élida Graziane Pinto, as despesas foram aprovadas como plano de uma determinada ação governamental, razão pela qual tal plano só não deveria ser cumprido com suficiente motivação. No entanto, “por vezes, o próprio Executivo não se compromete com o plano de ação e com os programas orçamentários que ele mesmo apresentou ao Legislativo por ocasião da proposta de lei de orçamento"276. É essa prática que se deve evitar.

\subsection{Os efeitos do contingenciamento na transparência do gasto público}

A transparência da coisa pública decorre das próprias formas republicana e democrática adotadas pela Constituição Federal. Se a "coisa" é pública e democrática, deve ser transparente, inclusive para se submeter ao controle. A Constituição Federal prevê o princípio da publicidade na administração pública (artigo 37) e o direito de acesso à informação (artigo $5^{\circ}, \mathrm{XIV}$ ), dos quais decorre a transparência.

Conforme destaca Regis Fernandes de Oliveira, "transparência significa que nada pode ficar escondido e às escuras, tudo deve ser público e subordinado aos procedimentos formais e sociais de controle" 277 .

O Brasil tem promovido alguns avanços rumo à transparência do gasto público. Em 2009, foi aprovada a Lei Complementar $n^{\circ} 131$, de 27 de maio de 2009, que modificou a Lei de Responsabilidade Fiscal, acrescendo-lhe o artigo 48-A, segundo o qual devem os entes da Federação disponibilizar informações referentes às despesas (todos os atos praticados pelas unidades gestoras no decorrer da execução da despesa, no momento de sua realização, com a disponibilização mínima dos dados referentes ao número do correspondente processo, ao bem fornecido ou ao serviço prestado, à pessoa física ou jurídica beneficiária do pagamento) e às receitas (o lançamento e o recebimento de toda a receita das unidades gestoras, inclusive referente a recursos extraordinários).

Em 2011, ocorreu a implementação da Lei de Acesso à Informação (Lei no 12.527/2011) que, dentre outros dados, busca assegurar acesso à "informação pertinente à

\footnotetext{
${ }^{276}$ PINTO, Élida Graziane. Financiamento de Direitos Fundamentais: políticas públicas vinculadas, estabilização monetária e conflito distributivo no orçamento da União do pós-Plano Real. Belo Horizonte: Editora O Lutador, 2010, p. 318.

277 OLIVEIRA, Regis Fernandes de. Curso de direito financeiro. $4^{\mathrm{a}}$ ed., ver., atual e ampliada. São Paulo: Revista dos Tribunais, 2011, p. 545.
} 
administração do patrimônio público, utilização de recursos públicos, licitação, contratos administrativos" 278 .

Não há dúvidas, portanto, que a transparência dos recursos públicos é um dos objetivos consagrados no ordenamento jurídico nacional, devendo ser premissa para e objetivo do Direito Financeiro.

Importa dizer que não basta a divulgação de números, é preciso poder compará-los, é necessário poder aferir critérios acerca da utilização dos recursos públicos. Nas palavras de Sergio Assoni Filho, "de nada adianta a simples divulgação (...) caso seu objeto venha veiculado a uma linguagem técnica e ininteligível ao cidadão comum, uma vez que é este seu legítimo destinatário"279.

Deve-se buscar ao máximo que a divulgação de dados permita conclusões que levem os controladores (institucionais ou populares) a pressionar contra gastos irregulares ou inadequados. Basile Christopoulos e Frederico Bastos apontam para a necessidade de um novo modelo de relacionamento entre cidadão e Estado, pautado na responsividade, accountability, confiança e transparência. Essa última precisa garantir não só a publicidade dos atos governamentais, mas especialmente deve propiciar que "os cidadãos sintam que fazem parte de um determinado grupo social e que seus governantes se preocupam em manter-lhes informados, de como as receitas auferidas com a tributação estão sendo gastos em benefício e de acordo com os anseios da sociedade" 280 .

Da mesma forma, Sergio Assoni Filho pontua que "a transparência da gestão fiscal não representa uma formalidade despicienda, mas sim tornar o cidadão apto à reflexão crítica e à avaliação sobre a forma como está sendo conduzida a atividade financeira estatal" $^{281}$.

Observa-se, assim, que a transparência não é um fim em si mesmo, mas um instrumento por meio do qual será possibilitado e incentivado o controle social, a verificação do atendimento dos anseios da sociedade e a reflexão sobre a condução da atividade estatal. Tal discussão passa também pelo contingenciamento.

Isso porque, o que se tem percebido tanto pelas análises doutrinárias quanto pelos dados da execução orçamentária é que o contingenciamento tem representado um relevante

\footnotetext{
${ }^{278}$ Artigo $7^{\circ}$, inciso VI da Lei ${ }^{\circ} 12.527 / 2011$.

${ }^{279}$ ASSONI FILHO. Sérgio. Transparência fiscal e democracia. Porto Alegre: Núria Fabris Ed., 2009, p. 198.

${ }^{280}$ CHRISTOPOULOS, Basile; BASTOS, Frederico Silva. Administração Tributária Eficiente, Democracia e Desenvolvimento: experiências internacionais sobre índices de transparência fiscal e sua utilidade para o Brasil. Revista Discente Direito GV, v. 1, p. 011-30, 2012.

${ }^{281}$ ASSONI FILHO. Sérgio. Transparência fiscal e democracia. Porto Alegre: Núria Fabris Ed., 2009, p. 198.
} 
entrave para a implementação da transparência. Não são poucas as dificuldades para se acompanhar o caminho do gasto público, desde a sua fixação na lei orçamentária anual até o seu efetivo pagamento.

Com baixos índices de execução orçamentária (especialmente em comparação com o orçamento aprovado), fica difícil acompanhar a execução de programas ou saber o real destino dos valores. Os reiterados contingenciamentos, aliados a remanejamentos de gastos, abertura de créditos adicionais, dentre outros instrumentos de flexibilização orçamentária, certamente dificultam essa análise. Por isso, repete-se aqui a mesma questão feita por Gustavo Alves: quando o gasto público diverge do orçamento previsto, mantémse o mesmo nível de transparência? ${ }^{282}$.

A partir dos dados disponíveis no Portal Siga Brasil (Portal do Orçamento), apresentados no presente trabalho, não é possível uma conclusão segura acerca do destino dos montantes não empenhados e também não pagos. É certo que parte do que foi previsto de fato não se tornou receita - já que a arrecadação não atinge $100 \%$ do previsto. Mas e o restante? Há geração de superavit primário, há inscrição de restos a pagar, há remanejamento para abertura de créditos adicionais?

Élida Graziane Pinto, analisando dados das décadas passadas, sugere que a resposta possa ser o cumprimento antecipado e majorado de superavit primário. Destaca a autora o "manejo abusivo da figura do contingenciamento" desde a década de 1990, especialmente quando o Executivo, "por meio de atos alheios à comprovação da frustração de receitas e do risco de afetação das metas fiscais, vem contingenciando discricionariamente elevados percentuais de despesas como mecanismo de cumprimento antecipado (e até majorado) da meta de superavit primário, 283 .

Pode-se extrair dessa conduta da Administração Pública uma tentativa de, postergando o pagamento de despesas, assegurar um cumprimento artificial da meta. Nessa linha esclarece Gustavo Alves que, como as despesas somente afetam o resultado quando pagas, "há um estímulo para que o governo retenha o pagamento das despesas do exercício

\footnotetext{
${ }^{282}$ ALVES, Gustavo Henrique Tardelli. O orçamento federal entre a realidade e a ficção: as armadilhas à transparência da despesa pública no Brasil. Monografia (especialização Curso de Orçamento Público). Instituto Serzedello Corrêa (ISC), 2012, p. 36.

${ }^{283}$ PINTO, Élida Graziane. Financiamento de Direitos Fundamentais: políticas públicas vinculadas, estabilização monetária e conflito distributivo no orçamento da União do pós-Plano Real. Belo Horizonte: Editora O Lutador, 2010, p. 307.
} 
para o ano seguinte, a fim de garantir o esforço fiscal apurado pelo resultado primário daquele exercício" ${ }^{284}$.

A falta de transparência não está relacionada apenas ao destino dos recursos não executados, mas também quanto aos próprios motivos do contingenciamento, conforme já se debateu neste estudo. Já se fez referência sobre a ausência de critérios transparentes na retomada da execução: internamente ao Executivo não se obedece a proporcionalidade em relação ao que foi limitado (inobservância do $\S 1^{\circ}$ do artigo $9^{\circ}$ da Lei de Responsabilidade Fiscal).

Essas conclusões são corroboradas por Vander Gontijo, que observa que a "discricionariedade" provoca o efeito indesejável de "escondimento da programação orçamentária em vigor após os ajustes determinados pelos decretos de contingenciamento ou de reprogramação orçamentária e financeira" ${ }^{285}$. É bastante prejudicial à transparência do gasto o procedimento utilizado no âmbito federal, descrito pelo citado autor:

O procedimento geralmente adotado consiste em solicitar que a autoridade ministerial ofereça ao Ministério do Planejamento o detalhamento da programação que deverá ser 'contingenciada' ou, mutatis mutandis, da que deverá permanecer no programa de trabalho. Essas informações não são publicadas ou tornadas disponíveis. Não entram no SIAFI como as que são decorrentes de remanejamento ou créditos adicionais. ${ }^{286}$

Ainda segundo Vander Gontijo, “depois de contingenciado, apenas algumas autoridades privilegiadas do Executivo têm conhecimento do que realmente 'restou' da Lei aprovada" $^{287}$. Essa constatação demonstra bem a falta de transparência que envolve o contingenciamento, tanto em relação à motivação quanto no tocante aos critérios para "liberação" de recursos. Impede-se, como já assinalado, um adequado planejamento para as políticas públicas. Impede-se também o exercício efetivo de controle pelo Legislativo e pela população.

Nesse sentido, é precisa a afirmação de Gustavo Alves, quando aponta que os prejuízos do contingenciamento (e consequente inscrição de elevados montantes de restos a pagar) não se limitam à dissociação entre orçamento e gasto, mas estão também relacionados à transparência da decisão sobre a despesa pública, que ordinariamente é

\footnotetext{
${ }^{284}$ ALVES, Gustavo Henrique Tardelli. $O$ orçamento federal entre a realidade e a ficção: as armadilhas à transparência da despesa pública no Brasil. Monografia (especialização Curso de Orçamento Público). Instituto Serzedello Corrêa (ISC), 2012, p. 37.

${ }^{285}$ GONTIJO, Vander. Orçamento impositivo, contingenciamento e transparência. In: Cadernos Aslegis, ${ }^{\circ}$ 39, p. 61-72, jan/abr 2010, p. 69.

${ }^{286}$ Ibidem, p. 69 (nota de rodapé $\mathrm{n}^{\circ} 19$ ).

${ }^{287}$ Ibidem, p. 70.
} 
materializada no processo legislativo orçamentário ${ }^{288}$. Ou seja, o prejuízo não é apenas em relação à realização das políticas públicas, ao planejamento e à transparência em si, mas todo esse conjunto dificulta o controle e a legitimidade democrática do gasto. Esse o tema do próximo item.

\subsection{Os efeitos do contingenciamento na legitimidade democrática do gasto público}

O contingenciamento, conforme se expôs, é ato a ser promovido pelo Poder Executivo via decreto. Ao contrário da fixação de despesas, que sempre deve passar pelo crivo do Poder Legislativo (exceto na situação dos créditos adicionais extraordinários), a sua indisponibilização é feita por ato unilateral do Executivo.

A exclusão do Legislativo dos processos de contingenciamento e descontingenciamento, aliado ao uso reiterado e imotivado desse mecanismo pelo Executivo, têm provocado um desequilíbrio na relação entre esses Poderes no âmbito orçamentário. Se há um déficit de participação do Legislativo na execução orçamentária, é natural concluir pela perda de controle democrático na concretização do gasto público.

Por mais críticas que se possam fazer ao Poder Legislativo, historicamente se verifica, desde as monarquias absolutistas, a importância da participação de outro Poder no debate orçamentário. Concentrar demasiadamente poderes sobre os recursos públicos não parece uma tendência republicana, tampouco democrática.

Neste passo, a despeito da iniciativa das leis orçamentárias ser da competência do Poder Executivo, o Poder Legislativo exerce função fundamental no sistema orçamentário brasileiro, competindo-lhe deliberar e aprovar a proposta orçamentária que lhe foi encaminhada $^{289}$. Conforme escreve José Maurício Conti, a iniciativa do Poder Executivo para propor as leis orçamentárias "é coerente com a organização e estrutura da Administração Pública, que tem o Chefe do Poder Executivo o responsável principal pela

\footnotetext{
${ }^{288}$ ALVES, Gustavo Henrique Tardelli. O orçamento federal entre a realidade e a ficção: as armadilhas à transparência da despesa pública no Brasil. Monografia (especialização Curso de Orçamento Público). Instituto Serzedello Corrêa (ISC), 2012.

${ }^{289}$ CONTI, José Maurício. Planejamento e Responsabilidade Fiscal. In SCAFF, Fernando Facury; CONTI, José Maurício. Lei de Responsabilidade Fiscal - 10 anos de Vigência - Questões Atuais. Florianópolis: Conceito Editorial, 2010, p. 125.
} 
sua condução" 290 . Porém, a iniciativa da proposta orçamentária, que consolida a fase administrativa de elaboração orçamentária, compreende apenas uma das etapas do orçamento. Há uma fase legislativa, com ampla possibilidade de participação do Poder Legislativo, ao menos em teoria.

No processo legislativo de elaboração do orçamento, há participação de comissões parlamentares, dentre as quais da Comissão Mista Permanente de Planos, Orçamentos Públicos e Fiscalização (CMO), a quem cabe "examinar e emitir parecer sobre os planos e programas nacionais, regionais e setoriais (...)" ${ }^{\text {"291 }}$. É no âmbito legislativo que se faz (i) a avaliação, fiscalização e controle da execução orçamentária; (ii) a avaliação da receita; (iii) a avaliação das informações sobre obras e serviços com irregularidades graves; e (iv) a admissibilidade de emendas ${ }^{292}$.

Ainda como funções do Legislativo, é possível realizar audiências públicas, com participação de Ministros de Estado, representantes dos órgãos de Planejamento, Orçamento e Fazenda e representantes dos demais órgãos do Poder Público. Essas audiências permitem municiar o Congresso de informações para intervir na elaboração orçamentária. As audiências públicas podem ser ainda em nível regional, com intuito de debater projetos de interesse de determinados Estados ou região geográfica.

A função que tem mais chamado atenção, entretanto, é a possibilidade de incluir emendas parlamentares ao orçamento, momento no qual se permite ao parlamentar estabelecer uma relação mais próxima com sua base eleitoral, ao menos em termos de financiamento de políticas públicas. É por meio dessas emendas que o parlamentar reserva recursos direcionados a projetos que beneficiem a população que o representa.

As normas sobre a elaboração do orçamento permitem, portanto, ampla participação do Legislativo na decisão sobre os recursos públicos, sendo esse um dos aspectos que confere legitimidade democrática ao gasto público. No entanto, a concretização da despesa pública não se limita a sua inclusão na Lei Orçamentária. Depois da elaboração, vem a execução, o contingenciamento e muitos dos problemas quanto à participação do Legislativo.

É nesse momento que se desequilibra a relação entre os Poderes no tocante ao gasto público: de nada adianta participar do debate e da alocação dos recursos no orçamento, se o

${ }^{290}$ CONTI, José Maurício. Iniciativa Legislativa em matéria financeira. In SCAFF, Fernando Facury; CONTI, José Maurício. Orçamentos Públicos e Direito Financeiro. São Paulo: Editora Revista dos Tribunais, 2011, p. 292.

${ }^{291}$ Artigo 166 da Constituição Federal.

${ }^{292}$ Conforme MENDONÇA, Eduardo Bastos Furtado de. Constitucionalização das Finanças Públicas no

Brasil. Rio de Janeiro: Renovar, 2010, pp. 25-41. 
Legislativo é excluído do principal mecanismo de interferência na execução orçamentária - o contingenciamento. A participação do Legislativo na decisão orçamentária é tema de intenso debate doutrinário.

Olhando para uma perspectiva histórica, Fernando Rezende e Armando Cunha analisaram os resultados da CPI do Orçamento e a atuação do Congresso pós-1988 (até 2003). Apontam os autores para um inicial "despreparo do Congresso Nacional para exercer novas prerrogativas que a Constituição de 1988 lhe havia reservado no capítulo orçamentário" ${ }^{293}$. Relatam inegáveis avanços na atuação do Legislativo, que, por exemplo, tornou-se mais "responsável e autônoma", com a publicização das discussões sobre reestimativas de receitas, bem como no reforço de sua capacidade técnica para dialogar com o Executivo. Entretanto, tais avanços se concentram na fase de elaboração do orçamento. Na execução orçamentária, os avanços ainda são poucos, e o contingenciamento segue sendo aplicado sem grandes controles e sem participação efetiva do Legislativo.

Olhando especificamente para a interferência do contingenciamento, Gabriel Lochagin questiona a quem deveria competir o controle do referido mecanismo. Concluiu o autor pela necessidade de participação do Legislativo, especialmente em razão de que tal Poder aprovou tanto a lei orçamentária anual quanto a Lei de Diretrizes Orçamentárias (e seus Anexos), razão pela qual teria competência técnica para influir na execução orçamentária. Na prática, porém, conforme constata o autor, há um controle parlamentar fraquíssimo, especialmente quando comparado com outros instrumentos de flexibilização orçamentária: "este controle fica reduzido a quase nada se tudo que o Poder Legislativo pode fazer é esperar o relatório da execução orçamentária para averiguar a decisão tomada pelo Poder Executivo" 294.

Sem exercer controle sobre o contingenciamento, tomado unilateralmente pelo Executivo, há impactos negativos na participação do Legislativo e, em consequência, na legitimidade democrática do orçamento.

Além da ausência de mecanismos específicos e mais claros para interferir no contingenciamento, a própria prática relativa a este instrumento de flexibilização orçamentária tem minado ainda mais as possibilidade de participação do Legislativo. Vejase que um dos principais problemas, já mencionados neste, estudo diz respeito à liberação

${ }^{293}$ REZENDE, Fernando; CUNHA, Armando. O Orçamento Público e a transição do poder. Rio de Janeiro: FGV, 2003, p. 57

${ }^{294}$ LOCHAGIN, Gabriel Loretto. A flexibilidade da execução orçamentária. Dissertação de Mestrado em Direito. Faculdade de Direito da Universidade de São Paulo. São Paulo, 2012. 
política de recursos a partir do contingenciamento. Essa característica dificulta ainda mais o exercício de controle pelo Legislativo. Aprofunda-se aqui o tema, referindo-se a diversos autores que observam e criticam a utilização do contingenciamento como forma de obtenção de apoio político.

José Maurício Conti aponta que a distorção no uso do contingenciamento, aliado à liberação oportuna de recursos públicos, "transformou o processo orçamentário em verdadeiro instrumento de 'compra' de apoio político do Legislativo por parte do Executivo" ${ }^{, 295}$. Conclui o mesmo autor que o instrumento, que deveria ser utilizado para gerenciar o fluxo de recursos, funciona como moeda de troca entre os Poderes por apoios políticos circunstanciais.

Marcos José Mendes, discutindo a baixa qualidade do gasto público, menciona como um dos fatores a dificuldade de o Executivo formar maioria no Congresso Nacional $^{296}$. Para mediar essa relação, o Executivo utiliza-se do orçamento e, mais especificamente, do controle sobre as emendas a partir do contingenciamento de gastos ${ }^{297}$. Segundo o autor, um dos grandes problemas está no fato de que o Executivo, desde logo, "faz o contingenciamento das verbas de modo a controlar as bases de apoio e manter o equilíbrio fiscal, mas executa parcialmente as demandas do Legislativo"298. Tal constatação demonstra a utilização do contingenciamento para fins e a partir de motivos que não aqueles previstos em lei.

A atuação do Executivo com vistas a dominar o Legislativo pelo contingenciamento também é mencionada por Cesar de Moraes Sabbag: "no modelo atual (que não se distingue dos orçamentos unilaterais do passado neste aspecto), as restrições financeiras funcionam como argumento de poder e eficiente artifício de controle político".

\footnotetext{
295 CONTI, José Maurício. Emendas ao Orçamento e o Desequilíbrio de poderes. Disponível em http://www.conjur.com.br/2012-jul-03/contas-vista-emendas-orcamento-desequilibrio-poderes. Acesso em 07/05/2013.

${ }^{296}$ MENDES, Marcos J. Sistema orçamentário brasileiro: planejamento, equilíbrio fiscal e qualidade do gasto público. Texto para discussão 39. Brasília: Consultoria Legislativa do Senado Federal, 2008, p. 42. ${ }^{297}$ Tendo em vista que as emendas do Legislativo provêm do corte de despesas ou da elevação da estimativa de receitas, a situação que ocorre é que "o Executivo subestima a receita porque sabe que o Congresso reestimará para cima" (...) "Depois o Executivo faz o contingenciamento das verbas, de modo a controlar a base de apoio e manter o equilíbrio fiscal. Mas executa parcialmente as demandas do Legislativo. Ao final do ano, a execução dos investimentos fica em um meio termo entre a proposta do Executivo e o desejo do Legislativo" (MENDES, Marcos J. Sistema orçamentário brasileiro: planejamento, equilíbrio fiscal e qualidade do gasto público. Texto para discussão 39. Brasília: Consultoria Legislativa do Senado Federal, 2008, pp. 14-15).

298 Ibidem, p. 15.
} 
Segundo o autor, os critérios para contingenciar e liberar recursos expressam "preferências pessoais, punições ou reconhecimentos" 299 .

Também tratando do controle de bases pelo Executivo, Maurício Barros afirma que uma das polêmicas em torno do contingenciamento diz respeito à "possibilidade de concessão de privilégios aos empenhos vinculados as chamadas 'bases aliadas' do Governo, bem como a possibilidade de utilização da execução do orçamento como instrumento de negociação com o Congresso Nacional"300.

Em pesquisa sobre a liberação de emendas parlamentares, Thiago Vesely conclui que "a liberação das emendas orçamentárias é realizada em lotes e negociada de forma coletiva pelos líderes partidários, que as utilizam como instrumento de controle dos liderados em prol da formação do presidencialismo de coalizão" ${ }^{\text {,301 }}$.

Em estudo sobre a atuação do Legislativo no processo orçamentário, Marcos Bezerra conclui que "enquanto dispositivo da administração governamental, o orçamento se presta, portanto, a implementação de práticas clientelistas por parte de deputados e senadores" ${ }^{302}$. O que se verifica é que essa característica é bastante incentivada e instrumentalizada pelo uso do contingenciamento, em conjunto com o baixo controle do Legislativo sobre a execução orçamentária.

Há que se admitir que um maior controle sobre a utilização do contingenciamento não resolve por inteiro os problemas da relação entre Executivo e Legislativo, inclusive no tocante às disputas orçamentárias. É, entretanto, um dos caminhos a serem perseguidos enquanto não se tem uma reforma política mais profunda ${ }^{303}$. De um lado, a prática do

299 SABBAG. Cesar de Moraes. Breves Considerações sobre deficiências estruturais do sistema orçamentário brasileiro. In CONTI, José Maurício; SCAFF, Fernando Facury (coord.). Orçamentos Públicos e Direito Financeiro. São Paulo: Editora Revista dos Tribunais, 2011, p. 456.

${ }^{300}$ BARROS, Maurício. Orçamento e Discricionariedade. In CONTI, José Maurício; SCAFF, Fernando Facury (coord.). Orçamentos Públicos e Direito Financeiro. São Paulo: Editora Revista dos Tribunais, 2011, p. 1001.

301 VESELY, Thiago Andrigo. Emendas orçamentárias como instrumento de coordenação no legislativo brasileiro. Monografia apresentada ao Programa de Pós-Graduação do Centro de Formação, Treinamento e Aperfeiçoamento da Câmara dos Deputados/CEFOR como parte da avaliação do Curso de Especialização em Política e Representação Parlamentar. Brasília, 2012, p. 36

${ }^{302}$ É bem verdade que o autor aponta que tal utilização é reforçada pelas normas orçamentárias que restringem a atuação do Legislativo e a alocação de recursos, mas aponta também para o problema dos vínculos políticos. E conclui: “a aprovação de emendas ao orçamento é um dos meios, não o único, através dos quais os parlamentares constroem e consolidam suas redes políticas. Além disso, observa-se que o atendimento dos pedidos de recursos, a busca de prestígio junto às bases eleitorais e o estabelecimento de compromissos através da aprovação de emendas orçamentárias não são coisas dissociadas do que os parlamentares, mas também lideranças locais, assessores parlamentares e outros concebem como sendo o exercício da política" (BEZERRA, Marcos O. Em nome das "bases”. Política, favor e dependência pessoal. Rio de Janeiro: Relume-Dumará, 1999, p. 79)

${ }^{303}$ Uma reforma política, com alterações no sistema eleitoral e de representação, poderia contribuir para melhorar a atuação do Legislativo no controle orçamentário. Entretanto, por uma escolha temática, não serão 
contingenciamento é uma consequência de um sistema político e eleitoral, com enormes problemas na governabilidade. De outro lado, o uso do contingenciamento reforça que essa relação entre os Poders seja mediada pelo "bloqueio" e "liberação" de recursos, sem critérios claros e muitas vezes afastados do interesse público.

Sobre o controle que poderia ser exercido pelo Legislativo, algumas propostas serão aprofundadas no capítulo seguinte. No presente tópico, pretendeu-se apenas demonstrar, por meio dos estudos apontados, a relação entre o contingenciamento e o déficit de legitimidade democrática do gasto público, especialmente decorrente da fraca atuação do Legislativo.

De se lembrar, entretanto, que a democracia não se limita (ou não deve se limitar) somente à atuação do órgão representativo, mas engloba (ou poderia englobar) também a atuação direta da população. Nesse sentido, embora não seja possível apontar efetivamente impactos negativos do contingenciamento na democracia direta (decorrente da atuação popular), é possível apontar algumas expectativas sobre a relação entre o contingenciamento e a participação popular no gasto público.

Vive-se um momento de aperfeiçoamento das instituições democráticas e do aumento das exigências por participação popular direta. Tais exigências não podem ser diferentes no âmbito do Direito Financeiro, que tem no orçamento participativo uma das formas de fortalecer a "legitimidade democrática direta" no gasto público.

Ocorre que o contingenciamento pode representar um indesejável obstáculo à concretização e ao fortalecimento do orçamento participativo. Essa observação representa antes uma preocupação com possíveis retrocessos na concretização de um orçamento mais democrático e mais legítimo, do que efetivamente uma constatação, até porque no presente trabalho não estão sendo analisados dados, tampouco mencionados estudos sobre este ponto específico ${ }^{304}$.

Verificou-se aqui que o contingenciamento tem forte impacto na execução do gasto público. São altos os índices de inexecução, são obscuros os critérios de "bloqueio" e "liberação" dos recursos, são distorcidos os motivos na utilização do contingenciamento. Transportando essas implicações para um mecanismo ainda frágil e de complexa

analisadas propostas específicas de reforma política, o que exigiria um estudo mais longo e próprio sobre o tema.

${ }^{304}$ Inclusive porque tal análise seria mais plausível no âmbito municipal, no qual o orçamento participativo tem maiores possibilidades de avançado. De qualquer forma, as conclusões tomadas para o orçamento como um todo causam preocupação quando se pensam em avanços democráticos mais ousados. 
implementação, que é o orçamento participativo, as previsões são as mais pessimistas possíveis.

O orçamento participativo é instrumento sem uma regulamentação geral, mas que conta com diversas iniciativas no país, especialmente em âmbito estadual e municipal ${ }^{305}$. Pode representar uma "política participativa em nível local que responda a demandas dos setores desfavorecidos por uma distribuição mais justa dos bens públicos". Tem também a importante função de buscar uma decisão mais descentralizada, muitas vezes com a criação de conselhos populares, com estímulo à formação de uma opinião pública e de um cidadão atento aos problemas locais, que eleja as prioridades e delibere sobre a alocação dos $\operatorname{recursos}^{306}$.

A aproximação da população das decisões sobre as políticas públicas via orçamento participativo pode ser inclusive um dos caminhos para suprir o déficit democrático existente no Legislativo. Nesse contexto, de aprofundamento dos debates políticos sobre a legitimidade, a participação popular nas decisões orçamentárias pode ser elemento fundamental. Peter Spink entende que, sem engajamento dos cidadãos, não há um orçamento público, mas, ao contrário, um orçamento privado que serve a grupos de interesses específicos. E por essa razão, diz o autor: “devemos priorizar e focalizar o processo de orçamento como o terreno privilegiado de disputa para a concretização da vida democrática e da inclusão social", utilizando as mais variadas técnicas e instrumentos possíveis $^{307}$.

Assim, deve o Direito Financeiro, em consonância com os seus demais objetivos, estimular e consolidar iniciativas de participação popular no orçamento, a fim de que se alcancem procedimentos mais adequados às deliberações populares. A despeito das dificuldades, o Brasil já foi modelo no cenário internacional, principalmente com o exemplo do orçamento participativo da cidade de Porto Alegre ${ }^{308}$.

No entanto, pensar o orçamento participativo unicamente como instrumento de elaboração orçamentária, esquecendo-se da execução, pode ser drástico. Isto porque,

\footnotetext{
305 Vide AVRITZER, Leonardo. Modelos de deliberação democrática: uma análise do orçamento participativo no Brasil. In: SANTOS, Boaventura de Sousa (org.). Democratizar a democracia: os caminhos da democracia participativa. Rio de Janeiro, Civilização Brasileira, 2002.

306 OLIVEIRA, Regis Fernandes de. Curso de direito financeiro. $4^{\mathrm{a}}$ ed., ver., atual e ampliada. São Paulo: Revista dos Tribunais, 2011, p. 411.

307 SPINK, Peter. Informação, transparência e cidadania - o controle da execução orçamentária pelo cidadão. In Cadernos de Gestão Pública e Cidadania, vol. 23. Junho de 2003, p. 03.

${ }^{308}$ Ver SANTOS, Boaventura de Sousa. Orçamento participativo em Porto Alegre: para uma democracia redistributiva. In: SANTOS, Boaventura de Sousa (org.). Democratizar a democracia: os caminhos da democracia participativa. Rio de Janeiro, Civilização Brasileira, 2002.
} 
seguindo o que se vê para o orçamento em geral, corre-se sério risco de não se atender minimamente ao que decidido a partir das deliberações populares. Se assim for, de nada adiantarão os avanços institucionais nos processos de elaboração e o engajamento da população. Se o contingenciamento atingir também o orçamento participativo, pode-se perder oportunidades importantes de se avançar democraticamente na decisão do gasto público.

A mesma preocupação é apresentada por Adilson Abreu Dallari: “de nada vale assegurar a participação popular no momento da elaboração do orçamento se, no decorrer do exercício financeiro, o Poder Executivo não tiver o dever de executar o que foi planejado mediante um processo de consulta pública (...)"309.

Lembra-se aqui de uma possível solução, que seria retirar do âmbito das despesas contingenciáveis aquelas decididas no orçamento participativo. Ter-se-ia, entretanto, mais um "sub-orçamento", com nível de execução diferenciada. Não seria o mais adequado. O melhor cenário é adequar o contingenciamento aos seus limites jurídicos e submeter todo o orçamento à mesma regra, seja ele "aprovado" pelo Legislativo ou por conselhos populares.

A observação que se pretende destacar diz respeito à importância da participação popular direta no âmbito orçamentário que, ainda em desenvolvimento, não pode ser tornar meramente lúdica, sem obrigatoriedade de o governante atender às decisões ${ }^{310}$. Se as deliberações populares seguirem o mesmo caminho do que se verifica para o Poder Legislativo, não influenciarão de fato o gasto público.

${ }^{309}$ DALLARI. Adilson Abreu. Orçamento Impositivo. In CONTI, José Maurício; SCAFF, Fernando Facury (coord.). Orçamentos Públicos e Direito Financeiro. São Paulo: Editora Revista dos Tribunais, 2011, p. 327.

310 OLIVEIRA, Regis Fernandes de. Curso de direito financeiro. $4^{a}$ ed., ver., atual e ampliada. São Paulo: Revista dos Tribunais, 2011, pp. 412/412. 


\section{O CONTROLE DO CONTINGENCIAMENTO}

\subsection{Aspectos gerais sobre o controle do contingenciamento}

O presente estudo fez análises quantitativas e qualitativas sobre os efeitos do contingenciamento na execução orçamentária, detacando-se problemas relativos à realização de políticas públicas, ao planejamento, à transparência e à legitimidade democrática do gasto público. Esses aspectos apontam para um distanciamento da prática do contingenciamento aos seus parâmetros e critério jurídicos.

Pretende-se agora, propor alguns caminhos para a solução ou amenização dos problemas que se têm discutido ao longo do trabalho.

Os caminhos para uma melhor aplicação do contingenciamento poderiam ser de diversos tipos. Poderia, por exemplo, ser de natureza eminentemente política, com os governos ou os representantes eleitos levando o orçamento mais a sério. Poder-se-ia, protestar diretamente ou por meio de representantes pela melhora na gestão dos recursos públicos e pela melhor aplicação do contingenciamento. Seria possível também pensar numa solução de natureza eminentemente econômica, propondo-se acabar com o superavit primário, não se importar com o crescimento da dívida ou, por outro lado, aumentar as receitas ou reduzir as despesas públicas. Não são esses os caminhos que se quer abordar.

Pretende-se pensar propostas de natureza eminentemente jurídica, embora haja uma forte intersecção com os âmbitos político, social e econômico, como quase tudo no Direito Financeiro. É certo que as propostas de caráter eminentemente jurídico trarão consequências nos âmbitos político e econômico. De qualquer modo, acredita-se que o Direito deve limitar as decisões políticas e econômicas. É o caso do contingenciamento, uma decisão com conteúdo político e econômico, mas com limites jurídicos.

Não se nega que deve ser reservado um espaço político e econômico acerca da decisão sobre o contingenciamento, mas o que se verifica atualmente é um abandono quase completo dos limites jurídicos. Assim como diversos outros instrumentos de flexibilização orçamentária, o contingenciamento apresenta uma abertura do sistema jurídico aos sistemas político e econômico, o que não permite dizer que inexistam limites jurídicos. No caso do contingenciamento, o limite têm cada vez mais se tornado simbólico e, por isso, impactado negativamente na concretização do Direito Financeiro. Daí, portanto, a necessidade de se pensar formas de controle sobre esse mecanismo. 
De se ressaltar que propor formas de controle na aplicação do contingenciamento não serve para retirar a flexibilidade inerente à condução do gasto e à implementação de políticas públicas. Não se pretende, igualmente, fazer prevalecer o binômio "pode/não pode" na discussão sobre "como se pode" alcançar os objetivos da administração pública, conforme interessante provocação de Diogo Coutinho. Para o mencionado autor, o Direito Administrativo "tem enfrentado dificuldades e limitações epistemológicas para se adaptar às metamorfoses do Estado e dos papéis de seu arcabouço jurídico na construção de políticas públicas" ${ }^{311}$.

Nessa linha, é preciso que o Direito não se limite a uma visão estanque, eminentemente negativa e voltada unicamente a limitar a discricionariedade. É necessário que ocupe diversas posições na implementação de políticas públicas: cristalizando opções políticas e determinando o que deve ser (Direito como objetivo); definindo tarefas, dividindo competências e articulando relações (Direito como arranjo institucional); funcionando como uma "caixa de ferramentas", oferecendo instrumentos para implementação dos fins da política (Direito como ferramenta); assegurando participação e accountability (Direito como vocalizador de demandas) ${ }^{312}$.

Além de identificar o que "pode/não pode”, ou seja, os limites jurídicos do contingenciamento, busca-se pensar, a partir de sua própria aplicação, em como estabelecer melhoras na implementação das políticas públicas, na relação entre os Poderes, no aumento da transparência e na participação democrática. Para isso, inevitável fazer críticas jurídicas à sua atual aplicação.

Feita essa breve digressão, passa-se a buscar soluções e a se apontar caminhos para um controle que exija uma aplicação mais adequada do contingenciamento, dentro de seus limites jurídicos. Não apenas de forma a limitar a discricionariedade do gestor público, mas também como forma de tornar o gasto público mais efetivo no atendimento aos direitos, melhor planejado, mais transparente e mais legítimo.

As propostas de controle são aqui pensadas a partir de três órgãos, que essencialmente possuem tal competência: Tribunal de Contas, Poder Legislativo e Poder Judiciário. Embora o Tribunal de Contas seja órgão auxiliar ao Poder Legislativo no controle externo das contas públicas, a análise será feita de forma separada para visualizar as competências distintas de cada um.

311 COUTINHO, Diogo R. O direito nas políticas públicas. P. 10. Artigo disponível em http://www.cebrap.org.br/v2/files/upload/biblioteca_virtual/item_766/14_05_12_16O_direito_nas_politicas_ publicas_FINAL.pdf. Acesso em 30/03/2014.

${ }^{312}$ Ibidem, p. 22. 
Divide-se, assim, o presente capítulo em três grandes tópicos, um para o controle de cada órgão, fazendo-se apontamentos de como cada um pode exercer o controle no âmbito orçamentário, em especial em relação ao contingenciamento.

\subsection{O Controle pelo Tribunal de Contas}

A Constituição Federal define, em seu artigo 71, que o controle externo das contas públicas, a cargo do Congresso Nacional, será exercido com o auxílio do Tribunal de Contas da União. Ao órgão compete, dentre outras funções, "apreciar as contas prestadas anualmente pelo Presidente da República, mediante parecer prévio (...)”, conforme inciso I do artigo 71 da Constituição Federal.

Para fins dessa competência, deve o Presidente da República fornecer as contas (através de balanços patrimoniais), bem como um relatório elaborado pelo sistema de controle interno do Poder Executivo ${ }^{313}$. Segundo o Regimento Interno do Tribunal de Contas, o relatório conterá informações sobre "o cumprimento dos limites e parâmetros estabelecidos pela Lei Complementar $n^{\circ} 101$, de 4/5/2000 - Lei de Responsabilidade Fiscal" ${ }^{\text {314 }}$. Portanto, se o contingenciamento tem limites e parâmetros estabelecidos na Lei de Responsabilidade Fiscal, deverá integrar o referido relatório, a ser apreciado pelo Tribunal de Contas.

Aliás, é expressa a preocupação do Tribunal de Contas em relação aos motivos e efeitos do contingenciamento na execução orçamentária, tanto que devem aparecer nos relatórios de gestão das unidades jurisdicionadas. Anualmente, o Tribunal de Contas divulga lista, prazos e orientações para apresentação e preenchimento do Relatório de Gestão pelas unidades jurisdicionadas (inclui Administração Direta e Indireta dos Poderes). Nos referidos relatórios, deve constar uma análise sobre os motivos e efeitos do contingenciamento, conforme se verifica, por exemplo das disposições da Portaria TCU $\mathbf{n}^{\circ}$ 175, de 09 de julho de $2013^{315}$. A referida Portaria, que estabeleceu as orientações para elaboração do conteúdo dos relatórios de gestão referentes ao exercício de 2013, faz duas menções (mais especificamente em seu Anexo Único) sobre a necessidade de análise do contingenciamento.

\footnotetext{
313 Artigo 221, parágrafo único do Regimento Interno do TCU.

${ }^{314}$ Artigo 228, parágrafo $2^{\circ}$, inciso III do Regimento Interno do TCU.

315 Nos anos de 2010, 2011 e 2012, eram semelhantes, nesse ponto, as disposições das Portarias que orientaram o preenchimento dos conteúdos dos relatórios de gestão.
} 
Primeiro, quando trata da "análise situacional" da "programação orçamentária e financeira" (item 2.2.2.1), esclarece que é preciso constar "informações que permitam um acompanhamento do desenvolvimento das escolhas efetivadas pelo governo para implementação da política", sendo analisados os "resultados relacionados aos objetivos fixados no PPA".

Essa análise de acompanhamento da programação orçamentária contemplará, dentre outros pontos, a execução de metas e seus fatores intervenientes, ou seja, "eventos que tenham prejudicado o desenvolvimento do objetivo, tais como dotação insuficiente ou contingenciamento nas ações concernentes ao objetivo (...), liberação de recursos orçamentários e financeiros fora dos prazos previstos (...)"316.

Verifica-se que o contingenciamento é reconhecidamente um fator que interfere no cumprimento do planejamento, na execução das metas, na implementação da política, razão pela qual a norma do tribunal considera "importante realçar as razões que motivaram as escolhas sobre quais programas e ações recairia, uma vez que as restrições orçamentárias e financeiras são estabelecidas para o órgão”. Há, portanto, orientação clara no sentido de que devem ser apreciados os motivos e os efeitos da decisão de contingenciar determinados programas.

Ainda sobre a Portaria TCU $\mathrm{n}^{\circ} 175$ e as orientações gerais para o relatório de gestão, quando esta trata da "análise crítica da realização de despesa" (item 4.1.3.7), impõe-se que essa análise deve consignar os efeitos do contingenciamento na gestão orçamentária, "destacando as consequências sobre os resultados planejados, bem como as razões que determinaram as escolhas sobre quais despesas as restrições recairiam". Mais uma vez a preocupação com os motivos e os resultados do contingenciamento.

Se de um lado, o Tribunal de Contas exige que as unidades relatem os efeitos do contingenciamento, de outro lado, questiona-se se, na prática, os relatórios de gestão fazem uma efetiva análise? Os órgãos seguem as orientações do Tribunal de Contas?

Para exemplificar, selecionam-se dois Ministérios: o mais afetado conforme média dos anos analisados (Ministério do Turismo) e o menos afetado de acordo com os mesmos critérios (Ministério do Desenvolvimento Social e Combate à Fome) ${ }^{317}$. Seleciona-se o último relatório, do ano de $2012^{318}$. Em ambos os Ministérios a constatação é a mesma,

\footnotetext{
316 Além do contingenciamento, outros fatores mencionados que atrapalham a execução são: não obtenção de licença ambiental, falta de estrutura, problemas na licitação, etc.

${ }^{317}$ Sempre considerando as despesas discricionárias, conforme explicações feitas no capítulo 03.

${ }^{318}$ Quando feita a pesquisa, ainda não haviam sido concluídos os relatórios do ano de 2013.
} 
com diferença de intensidade, mas sendo o contingenciamento apontado como principal responsável pela baixa execução orçamentária e pelo acumulo de restos a pagar.

No Relatório da Secretaria de Assistência Social (vinculada ao Ministério do Desenvolvimento Social e Combate à Fome) consta que "sob o aspecto orçamentáriofinanceiro, o contingenciamento de recursos obrigou o adiamento ou não execução de atividades previstas". Consta, ainda, o seguinte trecho: "a execução foi impactada pelo contingenciamento nas ações relacionadas a emendas parlamentares, havendo desbloqueio dos valores autorizados na LOA somente ao final do exercício"319.

No âmbito do Ministério do Turismo, em que a execução de despesas discricionárias foi muito baixa, há diversas críticas ao contingenciamento e à necessidade de se refazer o planejamento. Citam-se, por exemplo, alguns trechos do Relatório da Secretaria Nacional de Política de Turismo:

Outro fator contextual em 2012 foi o contingenciamento orçamentário ao qual foi submetido o Ministério do Turismo, e consequentemente a Secretaria Nacional de Políticas de Turismo, o que forçou inclusive a revisão de metas para algumas iniciativas previstas no Plano de Ação do Ministério, bem como orientou o processo de Revisão Anual do PPA.

O contingenciamento orçamentário imposto no início do exercício dificultou a execução e em alguns casos, comprometeu e alterou inclusive o planejamento feito por alguns departamentos para as ações sob sua responsabilidade.

(...) os limites estabelecidos no Decreto de Contingenciamento não permitiram a execução orçamentária da totalidade das ações programadas e incluídas pelo Congresso Nacional. Os limites estabelecidos no Decreto de Contingenciamento levaram o órgão a rever a sua forma de atuação frente às demandas do setor, inviabilizando a execução da totalidade do orçamento programado para algumas Ações Orçamentária ${ }^{320}$.

\footnotetext{
${ }^{319}$ BRASIL. Ministério do Desenvolvimento Social e Combate à Fome. Relatório de Gestão 2012 - Brasília, DF: MDS; Secretaria Nacional de Assistência Social, 2013. Disponível em

https://contas.tcu.gov.br/econtrole/ObterDocumentoSisdoc?codArqCatalogado=5931520\&seAbrirDocNoBro wser=1. Acesso em 19/02/2014. É bem verdade que no Relatório da Secretaria Executiva do MDS, observouse que "o Contingenciamento imposto pelo Decreto $\mathrm{n}^{\circ}$ 7.680, de 17 de fevereiro de 2012, não interferiu significativamente na execução do MDS”, como inclusive já se havia notado nos dados apresentados, porém, notaram-se efeitos preocupantes quanto ao planejamento do gasto.

${ }^{320}$ BRASIL. Ministério do Turismo. Relatório de Gestão 2012 - Brasília, DF. Secretaria Nacional de Políticas de Turismo, 2013. Disponível em

https://contas.tcu.gov.br/econtrole/ObterDocumentoSisdoc?codArqCatalogado=5930449\&seAbrirDocNoBro wser=1. Acesso em 19/02/2014. Não se mencionou aqui a Secretaria Executiva, pois esta é a menos afetada pelo contingenciamento em razão da natureza de suas despesas, voltadas à manutenção do órgão: “As despesas de responsabilidade da Secretaria-Executiva concentraram-se nas atividades de manutenção do órgão. Por esse motivo não houve contingenciamento de limite orçamentário, e observa-se uma execução bastante positiva o que se enquadra dentro da programação estabelecida para o exercício" (BRASIL. Ministério do Turismo. Relatório de Gestão 2012 - Brasília, DF. Secretaria Executivo, 2013. Disponível em https://contas.tcu.gov.br/econtrole/ObterDocumentoSisdoc?codArqCatalogado=5931562\&seAbrirDocNoBro wser=1. Acesso em 19/02/2014).
} 
Poder-se-ia citar inúmeros trechos de vários Ministérios, mas os exemplos ilustram que há uma avaliação dos efeitos do contingenciamento na execução orçamentária, inclusive atendendo a norma do Tribunal de Contas. Esses efeitos reforçam as conclusões acerca dos impactos negativos no planejamento e na realização das políticas públicas.

Porém, não é apenas a partir desses relatórios que o Tribunal de Contas verifica os efeitos negativos do contingenciamento sobre a execução orçamentária e a gestão dos recursos. Há também alguns julgados em que isso foi observado. Citam-se alguns exemplos recentes nos quais se encontrou a apreciação do contingenciamento pelo Tribunal de Conas.

Em novembro de 2013, o Senado Federal solicitou ao Tribunal de Contas da União informações relativas a obras públicas financiadas com recursos federais que se encontram paralisadas, ou seja, com seu andamento interrompido por mais de 1 ano, apontando, inclusive, as causas dessa paralisação ${ }^{321}$.

No relatório e na decisão exarada pelo Tribunal de $\operatorname{Contas}^{322}$, foram identificadas as causas das paralisações, sendo que a principal causa apontada foi o fluxo orçamentáriofinanceiro: $68,77 \%$ das obras inacabadas da União, $29,63 \%$ das obras inacabadas de Estados e Municípios com recursos da União e total de $39,75 \%^{323}$. Segundo o próprio acórdão, os problemas de "fluxo orçamentário-financeiro" são identificados como insuficiência de recursos já na elaboração da lei orçamentária, mas principalmente porque "na execução orçamentária ocorre uma realocação de recursos em virtude das limitações de empenho e de pagamento impostas pelo contingenciamento". Por isso, segundo descreve o próprio acórdão, "torna-se impossível cumprir os cronogramas de execução e as obras demoram múltiplas vezes o tempo necessário para serem concluídas, implicando em custos superiores aos inicialmente previstos, ou seja, causando prejuízo aos cofres públicos".

No acórdão citado, foram feitas diversas recomendações para a melhor execução das obras da União, dentre as quais se destaca:

A necessidade do Poder Executivo estabelecer critérios para regulamentar a contenção de recursos orçamentários e financeiros para os

\footnotetext{
${ }^{321}$ Conforme já discutido neste trabalho, cumpre observar que as obras são usualmente as mais afetadas pelo contingenciamento. Isto porque, há um valor mínimo a ser disponibilizado para que a obra se inicie ou prossiga. Ao contrário, em casos de compra de unidades, a exemplo de medicamentos ou outros materiais, o bloqueio de recursos pode ter como consequência a diminuição da quantidade, e não a total inviabilidade de cumprir o programa.

322 BRASIL. Tribunal de Contas da União. Plenário. Processo TC 032.114/2013-0. Acórdão no 46/2014. Relator Valmir Campelo. Julgado em 22/01/2014.

${ }^{323}$ Segundo o quadro constante do acórdão do TCU, esse é o principal fator responsável pelas obras inacabadas, sendo seguido de muito longe por problemas no projeto e execução da obra $(10,75 \%)$ e rescisão contratual (10,25\%). Menciona-se, ainda, que 24,50\% não tem motivo informado.
} 
empreendimentos componentes da Carteira de Projetos, de forma a viabilizar o cumprimento dos cronogramas definidos, com vistas a priorizar a aplicação de recursos nos empreendimentos em andamento; $(\ldots)^{324}$.

Mostra-se, portanto, que há uma preocupação do Tribunal com a falta de critérios do contingenciamento de recursos e os prejuízos causados na execução de obras públicas.

Confirmando as observações feitas ao longo do trabalho, de se mencionar também acórdão no qual o Tribunal de Contas da União fez importantes considerações sobre o acompanhamento da execução orçamentária e financeira da União em $2010^{325}$.

O relatório do acórdão reproduz análise da Secretaria de Macroavaliação Governamental (Semag), que analisou, dentre outros pontos, "a conformidade da execução de restos a pagar, as prioridades e metas fixadas na Lei de Diretrizes Orçamentárias, o contingenciamento orçamentário e financeiro e o comportamento do resultado primário". Destacam-se as seguintes ponderações sobre os impactos do contingenciamento:

(...) verifica-se a grande amplitude na distribuição da limitação orçamentária. Em que pese a média dos contingenciamentos ter sido próxima a $17 \%$, boa parte dos órgãos/unidades orçamentárias teve contingenciamento superior a um quarto dos recursos. Em cinco deles o volume contingenciado ainda permanece acima de $50 \%$. Se compararmos com outros exercícios, o forte contingenciamento em Ministérios como Cultura, Esporte e Turismo é recorrente, o que prejudica qualquer planejamento orçamentário que se pretenda fazer por ocasião da elaboração da proposta orçamentária.

Em posição oposta, alguns Ministérios bastante representativos em termos orçamentários apresentam percentuais de contingenciamento bem inferiores. É o caso de Saúde (2\%), Educação (5\%), Desenvolvimento Social (1\%) e Transportes (9\%).

O relatório bem aponta para os prejuízos no planejamento a partir dos reiterados contingenciamentos, bem como a grande diferença entre o previsto e o disponibilizado em diversos órgãos.

Nesse mesmo acórdão, o Tribunal de Contas, após ratificar as considerações da própria Semag, assevera para a necessidade de incorporar os impactos de desembolsos

\footnotetext{
${ }^{324}$ BRASIL. Tribunal de Contas da União. Plenário. Processo TC 032.114/2013-0. Acórdão no 46/2014. Relator Valmir Campelo. Julgado em 22/01/2014.

${ }^{325}$ BRASIL. Tribunal de Contas da União. Plenário. Processo 013.811/2010-0. Acórdão n ${ }^{\circ}$ 1143/2011. Relator Aroldo Cedraz. Julgamento em 11/05/2011.
} 
primários nas propostas orçamentárias, como forma de planejamento e com intuito de diminuir as limitações de movimentação e empenho durante a execução orçamentária ${ }^{326}$.

Novamente, sem pretender fazer uma revisão completa acerca dos julgamentos do Tribunal de Contas, o objetivo foi apontar que há uma percepção do Tribunal acerca dos problemas na aplicação desse instrumento de flexibilização orçamentária e suas consequências.

Como, então, poderia o Tribunal de Contas da União interferir para uma melhor aplicação do contingenciamento, pela sua aplicação dentro dos parâmetros jurídicos?

Além de algumas recomendações específicas que já ocorrem, uma das hipóteses seria a emissão de alertas, usual nos casos de descumprimento dos limites de dívida e de despesas com pessoal.

A emissão de alertas pode ser utilizada sempre que se constatar "fatos que comprometam os custos ou os resultados dos programas ou indícios de irregularidades na gestão orçamentária", conforme estabelece o artigo $59, \S 1^{\circ}$, inciso $\mathrm{V}$, da Lei de Responsabilidade Fiscal.

Por que não alertar o Executivo sobre irregularidades na aplicação do contingenciamento, já que, como se demonstrou, há consequências na gestão orçamentária, nos resultados dos programas e até nos custos das contratações?

O descumprimento do planejamento, a liberação de recursos no final do ano sem que haja tempo hábil para contratações adequadas, além da inobservância da proporcionalidade na liberação de recursos, são todos elementos que subsumem à situação descrita na norma.

Por fim, não se pode deixar de citar que o controle e a transparência das contas permitem a interferência das mais diversas organizações e também da população. $O$ artigo 73-A da Lei de Responsabilidade Fiscal estabelece que "qualquer cidadão, partido político, associação ou sindicato é parte legítima para denunciar ao respectivo Tribunal de Contas e ao órgão competente do Ministério Público o descumprimento das prescrições estabelecidas nesta Lei Complementar". Trata-se de outro mecanismo de controle, cuja utilização ainda precisa ser aprimorarada.

\footnotetext{
${ }^{326}$ As análises e recomendações são feitas considerando também a realização de receitas e o alcance das metas de resultado. O Tribunal não rechaça a importância do contingenciamento mas, mesmo levando em conta as as referidas variáveis, reconhece que há problemas em sua aplicação, conforme mencionado.
} 


\subsection{O controle pelo Poder Legislativo}

No capítulo anterior, algumas críticas foram feitas acerca da atuação do Legislativo na execução orçamentária. O Poder Legislativo analisa e aprova as propostas orçamentárias encaminhadas pelo Executivo, mas pouco participa de sua execução.

Poder-se-ia imaginar que o Congresso Nacional apenas atrapalharia a gestão do gasto público, impedindo o alcance de metas e resultados fiscais almejados pelo Poder Executivo. Porém, institucionalmente, há que se levar em conta a relevância de um controle democrático sobre o Executivo, que parece ter hoje a "chave dos cofres públicos". Como ainda se caminha lentamente rumo a mecanismos de democracia direta, o Legislativo, por mais problemas de representatividade que possa haver, é o órgão historicamente e institucionalmente desenhado para exercer tal controle.

No entanto, conforme se apontou em várias passagens deste trabalho, o contingenciamento tem sido utilizado para submissão do Legislativo perante o Executivo. Menciona-se novamente Gabriel Lochagin, que classifica como controle parlamentar fraquíssimo, aquele exercido sobre a execução orçamentária e o contingenciamento ${ }^{327}$. Reitera-se a opinião de José Maurício Conti acerca da distorção no uso do contingenciamento como instrumento de "compra" de apoio político do Legislativo por parte do Executivo ${ }^{328}$. São essas algumas das considerações já apontadas quando se tratou do déficit de legitimidade democrática do gasto público. Se naquele item o objetivo foi traçar um diagnóstico acerca dos efeitos do contingenciamento sobre essa legitimidade, agora o objetivo é traçar algumas possibilidades do que poderia representar um controle mais eficaz por parte do Poder Legislativo.

De se mencionar, inclusive, o entendimento de alguns autores no sentido de que a recuperação da participação do Legislativo é uma das formas de garantir maior qualidade ao gasto, especialmente no âmbito da legitimidade democrática. João Ricardo Catarino, em análise das finanças públicas dos Estados Europeus, entende ser necessário "melhorar o papel dos parlamentares nacionais no processo orçamental”. Propõe como medidas o aumento do período de discussão do projeto de lei orçamentária e o reforço da

\footnotetext{
${ }^{327}$ LOCHAGIN, Gabriel Loretto. A flexibilidade da execução orçamentária. Dissertação de Mestrado em Direito. Faculdade de Direito da Universidade de São Paulo. São Paulo, 2012.

328 CONTI, José Maurício. Emendas ao Orçamento e o Desequilíbrio de poderes. Disponível em http://www.conjur.com.br/2012-jul-03/contas-vista-emendas-orcamento-desequilibrio-poderes. Acesso em 07/05/2013.
} 
orçamentação como programa, o que aumentaria, por via reflexa, a participação dos cidadãos $^{329}$.

Outras propostas são apontadas por César de Moraes Sabbag, dentre as quais está a atribuição ao Legislativo de parcela da iniciativa dos projetos de leis orçamentárias, a revitalização da Comissão Mista do orçamento (que deveria discutir temas como endividamento, metas fiscais e investimentos prioritários) e, por fim, a anuência parlamentar para que determinado gasto não se realize. Essas modificações ajudariam a reduzir a feição antidemocrática do orçamento, resultante da "concentração de poderes no Executivo, da subalternidade parlamentar e do total afastamento popular do processo decisório",330.

Avançando no tema, pode-se pensar em um controle a partir das competências já existentes, bem como de algumas propostas de inovação normativa.

Na Constituição Federal, estão algumas competências do Poder Legislativo que poderiam ser utilizadas para fiscalização da execução orçamentária. Segundo o artigo 49 da Constituição Federal, é de competência exclusiva do Congresso Nacional:

(...)

IX - julgar anualmente as contas prestadas pelo Presidente da República e apreciar os relatórios sobre a execução dos planos de governo;

$\mathrm{X}$ - fiscalizar e controlar, diretamente, ou por qualquer de suas Casas, os atos do Poder Executivo, incluídos os da administração indireta; (...)

Dentro da competência do artigo 49, incisos IX e X, está a possibilidade de o Legislativo apreciar relatórios sobre a execução dos planos de governo e de fiscalizar e controlar os atos do Poder Executivo. Dos relatórios de gestão e das próprias informações sobre a execução orçamentária, verifica-se que os planos de governo, ao menos no tocante às despesas discricionárias, estão longe do que previsto e do que aprovado pelo próprio

\footnotetext{
${ }^{329}$ O professor português diagnostica o caso europeu da seguinte forma: "Na generalidade dos Estados europeus, como também noutras partes, o Orçamento do Estado é votado e aprovado nas assembléias representativas dos cidadãos. Todavia, há neste respeito um conjunto de melhorias que beneficiariam o processo orçamental propriamente dito, assim como o lugar do cidadão no sistema político. Assim, em primeiro lugar, o período para discussão da proposta orçamentária deveria ser alargado. Isso reforçaria a transparência orçamental e daria tempo suficiente para a análise da proposta do Governo. A existência de Comissões especializadas nas Assembléias legislativas nacionais não tem garantido, por si, uma análise suficientemente profunda das propostas dos Governos, permitindo-lhes fazer passar, com relativa facilidade, todas as suas medidas (CATARINO, João Ricardo. Processo Orçamental e sustentabilidade das finanças públicas: o caso europeu. In SCAFF, Fernando Facury; CONTI, José Maurício (coord.). Orçamentos Públicos e Direito Financeiro. São Paulo: Editora Revista dos Tribunais, 2011, p. 798.

${ }^{330}$ MORAES, Cesar de. Breves Considerações sobre deficiências estruturais do sistema orçamentário brasileiro. In CONTI, José Maurício; SCAFF, Fernando Facury (coord.). Orçamentos Públicos e Direito Financeiro. São Paulo: Editora Revista dos Tribunais, 2011, pp. 459-460.
} 
Legislativo. A competência do Legislativo, ao apreciar os relatórios, serviria, ao menos, como maneira de pressionar o Executivo por justificativas mais adequadas, incentivando uma execução orçamentária mais consistente do ponto de vista do planejamento e da transparência.

Conforme esclarecem João Batista Pontes e João Henrique Pederiva, “apreciar os relatórios sobre a execução dos planos de governo aponta para uma avaliação integrada da execução das leis orçamentárias, bem como do planejamento estatal subjacente ao conjunto do ordenamento jurídico brasileiro". Embora, segundo complementam os autores, integrantes da Consultoria Legislativa do Senado, tal apreciação não se enquadre estritamente no conceito de "julgamento", a apreciação se insere num contexto de aperfeiçoamento da democracia e da forma de agir do governo, configurando-se como “fonte de esclarecimentos de grande valor, podendo determinar, sugerir, apontar e exigir uma série de providências tendentes ao aperfeiçoamento, tanto dos planos e das políticas definidas, quanto do desempenho da administração pública"331.

Cita-se, ainda, como competência constitucionalmente estabelecida, a possibilidade de convocar Ministros de Estados ou titulares de órgãos subordinados à Presidência para prestarem informações, conforme artigo 50 da Constituição Federal ${ }^{332}$. Com amparo nessa competência, poderia o Congresso Nacional convocar titulares dos órgãos e Ministérios responsáveis pela execução orçamentária, para que esclareçam os motivos de contingenciamento, bem como os critérios sobre prioridades, bloqueio e liberação de recursos.

Verifica-se, assim, que possui o Legislativo alguns mecanismos institucionais para fortalecer o seu controle sobre a execução orçamentária, os quais foram inclusive ampliados na atual Constituição Federal.

O que se observa, entretanto, é que, apesar das determinações constitucionais no sentido de uma atuação compartilhada entre os Poderes, há um “amplo domínio do Poder Executivo à frente da definição das prioridades orçamentárias, especialmente na fase de

331 PONTES, João Batista Pontes; PEDERIVA, João Henrique. Contas Prestadas pelo Presidente da República: Apreciação do Congresso Nacional. Texto para discussão 14. Brasília: Consultoria Legislativa do Senado Federal, 2004, p. 08. Disponível em http://www12.senado.gov.br/publicacoes/estudoslegislativos/tipos-de-estudos/textos-para-discussao/td-14-contas-prestadas-pelo-presidente-da-republicaapreciacao-do-congresso-nacional. Acesso em 11/03/2014.

332 "Art. 50. A Câmara dos Deputados e o Senado Federal, ou qualquer de suas Comissões, poderão convocar Ministro de Estado ou quaisquer titulares de órgãos diretamente subordinados à Presidência da República para prestarem, pessoalmente, informações sobre assunto previamente determinado, importando crime de responsabilidade a ausência sem justificação adequada." 
execução do orçamento, valendo-se o mesmo de mecanismos que o permitem afastar-se das previsões contidas na peça orçamentária aprovada pelo Poder Legislativo"333.

Nada obstante, faz-se nova referência ao denominado projeto de "orçamento impositivo", já descrito neste trabalho ${ }^{334}$ e que propõe reforçar a atuação do Legislativo.

Lembra-se que tal projeto visa tornar "obrigatória" a execução das despesas decorrentes de emendas parlamentares (com algumas especificidades). Se houver problemas na arrecadação (e cumprimento de metas), é possível o contingenciamento de tais despesas.

Mais do que tornar as emendas parlamentares de "execução obrigatória", é interessante notar as alterações quanto ao papel do Legislativo na hipótese específica de “contingenciamento" dessas despesas ou, nos termos da redação proposta ao $§ 14$ do artigo 166 da Constituição Federal, "no caso de impedimento de ordem técnica, no empenho de despesa que integre a programação" (das emendas parlamentares).

Nesses casos de "impedimento de ordem técnica", o Executivo deve ao menos justificativas ao Legislativo. Assim: (i) em até 120 dias da publicação da lei orçamentária, todos os poderes, inclusive o Executivo, enviarão ao Poder Legislativo as justificativas do impedimento; (ii) após trinta dias desse prazo, é o Poder Legislativo que indica ao Poder Executivo o remanejamento da programação cujo impedimento seja insuperável; (iii) posteriormente, e até 30 de setembro, deve o Poder Executivo encaminhar projeto de lei sobre o remanejamento da programação cujo impedimento seja insuperável; (iv) por fim, até 20 de novembro (ou até trinta dias após o término do prazo anterior), o Executivo implementará o remanejamento proposto, apenas se o Congresso Nacional não deliberar sobre o projeto de remanejamento ${ }^{335}$.

Veja-se o reforço na participação do Legislativo no controle e nos remanejamentos em relação ao orçamento aprovado. O Legislativo passa a receber diretamente as justificativas de um possível contingenciamento e de não execução orçamentária. Trata-se de proposta importante, embora mereça críticas o fato de que as exigências referem-se apenas às despesas decorrentes de emendas parlamentares individuais. Seria relevante que houvesse um fortalecimento do controle e da atuação do Poder Legislativo sobre a

\footnotetext{
${ }^{333}$ DALLAVERDE, Alexandra Katia. As relações entre os poderes na gestão das Finanças Públicas. Porto Alegre: Nuria Fabris Editora, 2013, p. 219.

${ }^{334}$ BRASIL. Câmara dos Deputados. Proposta de Emenda à Constituição no 22A, de 2000 (n 565, de 2006, na Câmara dos Deputados), que propõe alteração do artigo 166 da Constituição Federal. Redação para o segundo turno.

${ }^{335}$ Trata-se da pretensão de inserir na constituição disposição semelhante àquela que foi trazida também pelo no artigo 52 da LDO 2014, também já mencionada no presente trabalho.
} 
execução de todo o orçamento, e não somente daquelas despesas que afetam diretamente e individualmente os interesses dos parlamentares.

Uma proposta mais ampla, também visando reforçar o orçamento aprovado pelo Legislativo, é o projeto descrito por Regis Fernandes de Oliveira. Segundo o autor, então deputado federal, o projeto de sua autoria limitava o contingenciamento do Executivo ao caso de não haver realização das receitas ${ }^{336}$. Assim, "se o montante das receitas equivale ao das despesas previstas, o cumprimento exato do orçamento torna-se obrigatório"337. Conforme o referido projeto, só não seria possível executar o orçamento previsto com autorização pelo Congresso Nacional, a partir de uma "solicitação, de iniciativa exclusiva do Presidente da República, para cancelamento ou contingenciamento, total ou parcial, de dotação",338.

Trata-se também de uma tentativa de reforçar o papel de controle do Legislativo sobre as contas públicas, na linha do que ocorre em outros países, a exemplo da Alemanha e dos Estados Unidos, tal como descrito por Gabriel Lochagin ${ }^{339}$. O autor analisou a impositividade do orçamento na Alemanha e nos Estados Unidos, mormente sob a perspectiva da participação do Legislativo na decisão do contingenciamento, apontando para relevantes diferenças em relação ao funcionamento do orçamento no Brasil.

$\mathrm{Na}$ Alemanha, em algumas situações, a liberação de recursos públicos orçamentários "bloqueados" exige o consentimento da Comissão de Orçamento do Parlamento. Em outros casos, é necessário também o consentimento de um comitê técnico

\footnotetext{
${ }^{336}$ Pela interpretação feita no presente trabalho, esta já é a determinação atual. Porém, o descumprimento reiterado e praticamente "institucionalizado" na execução orçamentária fez com que se entendesse necessário um esclarecimento sobre este aspecto.

${ }^{337}$ OLIVEIRA, Regis Fernandes de. Curso de direito financeiro. $4^{\mathrm{a}}$ ed., ver., atual e ampliada. São Paulo: Revista dos Tribunais, 2011, p. 376. Segundo o citado autor, "o projeto foi arquivado, como o são todos os projetos não apreciados em uma comissão até o fim da legislatura”.

338 Conforme Proposta de Emenda Constitucional no 22 de 2000, que inclui o artigo 165-A na Constituição Federal: “Art. 165-A. A programação constante da lei orçamentária anual é de execução obrigatória, salvo se aprovada, pelo Congresso Nacional, solicitação, de iniciativa exclusiva do Presidente da República, para cancelamento ou contingenciamento, total ou parcial, de dotação.

$\S 1^{\circ}$ A solicitação de que trata o caput deste artigo somente poderá ser formulada até cento e vinte dias antes do encerramento da sessão legislativa e será acompanhada de pormenorizada justificativa das razões de natureza técnica, econômico-financeira, operacional ou jurídica, que impossibilitem a execução.

$\S 2^{\circ}$ A solicitação poderá, ainda, ser formulada a qualquer tempo, nas situações que afetem negativamente a arrecadação da receita, de calamidade pública de grandes proporções, ou ainda nas previstas no art. 137, inciso II.

$\S 3^{\circ}$ Em qualquer das hipóteses, as solicitações tramitarão no Congresso Nacional em regime de urgência. $\S 4^{\circ}$ Não havendo deliberação do Congresso Nacional, no prazo de trinta dias, a solicitação será considerada aprovada.

$\S 5^{\circ}$ A não execução de programação orçamentária, nas condições previstas neste artigo, implica crime de responsabilidade. (...)"

${ }^{339}$ LOCHAGIN, Gabriel Loretto. A flexibilidade da execução orçamentária. Dissertação de Mestrado em Direito. Faculdade de Direito da Universidade de São Paulo. São Paulo, 2012.
} 
parlamentar. São os denominados contingenciamentos qualificado e duplamente qualificado.

Nos Estados Unidos, a formalização dos contingenciamentos presidenciais passou a observar alguns requisitos: "caso não deseje gastar o total dos fundos previstos para determinada despesa, o Presidente necessita propor ao Congresso a rescisão da dotação (rescission) (...) se quiser apenas atrasar o gasto, deveria propor seu diferimento (deferral)" ${ }^{340}$. Alexsandra Dallaverde também faz referência à legislação dos Estados Unidos, descrevendo a "Solicitação Governamental ao Congresso", por meio do qual o Executivo submete à autorização legislativa o cancelamento definitivo (rescission) ou o adiamento das despesas (deferral) ${ }^{\text {"341 }}$.

Sem pretender realizar um estudo comparado, tais exemplos demonstram a existência de mecanismos mais fortes de controle do Parlamento sobre a decisão de gastar ou não gastar. Essa decisão não fica limitada ao momento da elaboração do orçamento, mas se estende também à execução, permitindo um equilíbrio entre a vontade parlamentar e a política econômica e fiscal definida pelo Executivo.

Portanto, além das competências atuais do Legislativo, mais especificamente do Congresso Nacional, pouco utilizadas para fins de controle da aplicação do contingenciamento, estão em discussão propostas normativas voltadas a reforçar esse controle. Embora muitas vezes as discussões em curso no Brasil sejam voltadas para as despesas fixadas a partir de emendas parlamentares, um reforço da atuação do Legislativo seria desejável em todo o orçamento, no intuito de, dentre outras funções, pressionar por uma aplicação mais adequada do contingenciamento, dentro de seus parâmetros jurídicos.

\subsection{O Controle pelo Poder Judiciário}

\subsubsection{Breve revisão da relação entre Judiciário e orçamento}

A atuação do Poder Judiciário em face de questões orçamentárias é tema de grande debate. Discute-se tanto a possibilidade de decisões intervirem na programação orçamentária, quanto a possibilidade de o Judiciário efetuar o controle de legalidade e constitucionalidade das normas orçamentárias.

\footnotetext{
${ }^{340}$ Ibidem, p. 144.

${ }^{341}$ DALLAVERDE, Alexandra Katia. As relações entre os poderes na gestão das Finanças Públicas. Porto Alegre: Nuria Fabris Editora, 2013, p. 221.
} 
As decisões judiciais que de alguma forma tratam do orçamento movimentam a linha tênue que separa o âmbito político e o âmbito jurídico do gasto público. Se, de um lado, o Judiciário deve respeitar o conteúdo político do gasto público - essa decisão cabe ao Executivo e ao Legislativo; não pode, de outro lado, deixar de apreciar a legalidade e a constitucionalidade de tais decisões - os contornos jurídicos do gasto público. O limite nem sempre é claro e, consequentemente, o Poder Judiciário por vezes deixou de apreciar questões jurídicas indevidamente, e outras tantas, adentrou em questões políticas sobre as quais não teria competência para decidir. Esse o conflito que se pretende discutir.

No primeiro capítulo, ao tratar da natureza do orçamento, analisou-se a evolução jurisprudencial, no âmbito do Supremo Tribunal Federal, acerca da possibilidade de controle judicial da lei orçamentária. Concluiu-se no sentido de que atualmente há uma forte tendência favorável ao exercício do controle de constitucionalidade da lei orçamentária. De se lembrar que na Ação Direta de Inconstitucionalidade $n^{\circ} 4.048^{342}$, julgada em 2008, a decisão foi no sentido de que deve o Tribunal exercer sua função de fiscalização da constitucionalidade das leis, independente do caráter geral ou específico, concreto ou abstrato de seu objeto.

A decisão tomada na Ação Direta de Inconstitucionalidade nº 4.048 representou um avanço no tocante à observância das normas constitucionais de Direito Financeiro, por vezes descumpridas em razão de justificativas econômicas e políticas. A partir do momento em que o Supremo Tribunal Federal é também guardião das normas constitucionais de Direito Financeiro, há maiores chances de que os preceitos jurídicos em matéria orçamentária sejam concretizados. Isso não significa, entretanto, que está clara a distinção entre o que são os limites jurídicos e o que é o conteúdo político no âmbito orçamentário.

Essa é, entretanto, apenas um das faces da atuação judicial perante o gasto público. A relação entre Judiciário e orçamento é ainda mais comum quando o tema envolve o atendimento de demandas individuais e coletivas por direitos sociais, como saúde e educação, independentemente de previsão orçamentária. Ao garantirem direitos para um indivíduo ou uma coletividade, as decisões judiciais interferem na programação orçamentária. Trata-se de uma atuação constitucionalmente legítima? Ou, por outro lado, deveria o Judiciário se limitar ao controle de legalidade e constitucionalidade das normas

342 BRASIL. Supremo Tribunal Federal. Pleno. ADI 4.048/DF. Relatora Ministro Gilmar Mendes. Julgamento em 14/05/2008. 
orçamentárias? Algumas considerações sobre a relação entre Judiciário e orçamento são relevantes antes de tratarmos do controle judicial do contingenciamento.

Menciona-se, novamente, que a implementação do extenso rol de direitos sociais trazidos pela Constituição Federal de 1988 requer, além de tempo, emprego de recursos. São direitos que exigem prestações positivas do Estado, normalmente concretizadas através de políticas públicas.

Como os recursos são escassos, a implementação desses direitos implica nas denominadas escolhas trágicas. Ou seja, não serão contemplados instantaneamente todos os direitos de todas as pessoas - serão tomadas decisões que incluem uns e excluem outros. Um exemplo clássico se refere ao direito à saúde e a concessão de medicamentos pelo Estado. Uma vez que a lista de medicamentos do Sistema Único de Saúde é limitada, a inclusão de um determinado medicamento representa a alocação de recursos públicos para este fim em detrimento de gastos em outras áreas ou programas ou até em outro medicamento.

A previsão de direitos sociais (ou direitos que exigem prestações positivas) na Constituição Federal, aliada à escassez de recursos, levou muitos daqueles que não estavam contemplados pelas políticas públicas a buscar o Judiciário para tentar, de alguma forma, atribuir eficácia direta a tais direitos.

Como esclarece Fernando Facury Scaff ao tratar do direito à saúde, "na ânsia de implementar integralmente as normas constitucionais, vem ocorrendo no Brasil uma avalanche de decisões de todas as instâncias implementando diretamente o direito à saúde

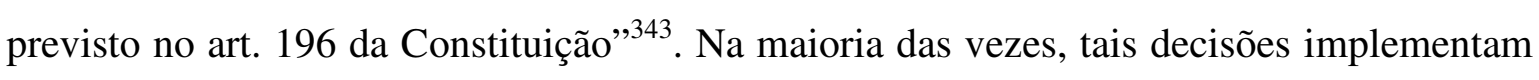
diretamente e de forma individual direitos que deveriam ser concretizados através de políticas públicas de caráter global e de acordo com alocações dos recursos no orçamento.

As decisões judiciais implicam que a escolha passe do âmbito do Executivo e do Legislativo para o Judiciário. Seguindo no exemplo do direito à saúde, são comuns as decisões que concedem tratamentos não previstos pelo SUS (Sistema Único de Saúde) a indivíduos que recorrem ao Poder Judiciário. Necessariamente serão retirados recursos de outros programas para atender aquele indivíduo: “com estas decisões, os programas e as políticas públicas de saúde têm sido bastante abalados financeiramente, e comprometida

\footnotetext{
343 SCAFF, Fernando Facury. A efetivação dos direitos sociais no Brasil: garantias constitucionais de financiamento e judicialização. In: Fernando Facury Scaff; Roberto Romboli; Miguel Revenga. (Org.). A Eficácia dos Direitos Sociais - I Jornada Internacional de Direito Constitucional Brasil/Espanha/Itália. 1 ed. São Paulo: QuartierLatin, 2009, v. 1, p. 35.
} 
sua capacidade de implementação - confundem-se direitos individuais com direitos sociais" 344 .

Na mesma linha é a consideração de Virgílio Afonso da Silva, para quem direitos sociais não podem ser encarados como os direitos individuais (civis e políticos), ou seja, “juízes não podem ignorar as políticas públicas já existentes nessas áreas, concedendo, de forma irracional e individualista, medicamentos, tratamentos de saúde ou vagas em salas de aula a todo aquele que recorrer ao Judiciário",345.

Tem-se, assim, o grande problema da implementação judicial dos direitos sociais: tratá-los de maneira individual, desconsiderando políticas públicas existentes. Essa prática certamente culmina em uma "captura orçamentária individual", o deve ser visto com extrema cautela, a fim de se evitar que a judicialização dos direitos sociais seja tratada como uma mera lide entre credor e devedor. Como bem pontua Virgílio Afonso da Silva, corre-se o risco de haver uma "simples transposição de uma racionalidade da tradição liberal, baseada quase que exclusivamente em relações bilaterais - normalmente entre um credor e um devedor - para a área dos direitos sociais"346.

Quando, então, seria possível a intervenção do Judiciário nas políticas públicas para garantia de direitos sociais?

Ingo Sarlet, aproximando-se das concepções de Alexy e Canotilho, entende que a solução deve ser calcada nas circunstâncias do caso concreto, uma vez ser impossível estabelecer uma pauta genérica e abstrata de diretrizes e critérios: "não há como resolver a problemática em termos de tudo ou nada". Sarlet propõe, assim, que deve ser reconhecido o direito subjetivo a prestações sempre que "os argumentos relativos à reserva de competência do Legislativo esbarrar no valor maior da vida e da dignidade da pessoa humana, ou nas hipóteses em que, da análise dos bens constitucionais colidentes resultar a prevalência do direito social prestacional", devendo ser sempre garantido um mínimo existencial. Trata-se de uma forma de interpretação, para a qual o autor invoca, inclusive, a busca do meio-termo e da justa medida ${ }^{347}$.

Embora a posição pretenda um meio-termo, uma justa medida, e apresenta avanços em relação às posições "tudo ou nada", reside ainda um problema: a garantia do mínimo

\footnotetext{
${ }^{344}$ Ibidem, p. 35.

${ }^{345}$ SILVA. Virgílio Afonso. O Judiciário e as políticas públicas: entre transformação social e obstáculo à realização dos direitos sociais. In: SOUZA NETO, Cláudio Pereira de; SARMENTO; Daniel. Direitos sociais: fundamentação, judicialização e direitos sociais em espécies. Rio de Janeiro: Lumen Juris, 2008, p. 588.

346 Ibidem, p. 588.

${ }^{347}$ SARLET, Ingo Wolfgang. A Eficácia dos Direitos Fundamentais. Porto Alegre: Livraria do Advogado, 2001, p. 324.
} 
existencial fica vinculada aos indivíduos que tem acesso ao Judiciário. Ao final, a ponderação entre a reserva de competência e a reserva do possível, de um lado, e o direito à vida e a dignidade da pessoa humana, de outro lado, apenas funcionará para os indivíduos que ingressam no Judiciário. Em última instância, haverá necessariamente captura de recursos por tais indivíduos, seguramente em detrimento de outros indivíduos, sem acesso ao Judiciário, cuja vida e dignidade também estão sendo afetadas.

Sem a pretensão de resolver a questão, propõe-se aqui que a atuação do Judiciário (e dos demais órgãos de controle) deva ser tratada a partir de outra perspectiva, centrada mais na coletividade e menos no indivíduo. O próprio Ingo Sarlet reconhece que "os direitos fundamentais devem ter sua eficácia valorada não só sob um ângulo individualista (...), mas também sob o ponto de vista da sociedade, da comunidade na sua totalidade, já que se cuida de valores e fins que esta deve respeitar e concretizar" ${ }^{\prime 348}$.

Não se pode abandonar a ideia de que qualquer que seja o posicionamento, haverá problemas, já que se está tratando de recursos escassos e escolhas trágicas. De qualquer modo, deve-se reconhecer que houve uma mudança de perspectiva na relação entre direitos e Justiça, decorrente da "valorização dos direitos fundamentais na condição de normas de direito objetivo", também denominada "autêntica mutação dos direitos fundamentais". Essa mudança é provocada principalmente pela "transição do modelo de Estado liberal para o do Estado social e democrático de Direito, como também pela conscientização da insuficiência de uma concepção dos direitos fundamentais como direitos subjetivos de defesa (...) $)^{\text {349 }}$.

Nem toda a atuação judicial é condenável. Não se abandona a ideia de que os direitos fundamentais, principalmente os direitos sociais, não se configuram como meras normas programáticas, sendo possível a atuação judicial nessa seara. Por outro lado, a atuação judicial via demandas individuais não é a forma juridicamente mais adequada para se garantir a efetividade dos direitos sociais, pois ignora os aspectos orçamentários e a dimensão coletiva que tais direitos envolvem. É por isso que haverá maior legitimidade na atuação do Judiciário, quanto mais forem considerados os aspectos orçamentários (afinal, o orçamento é discutido no âmbito do Legislativo e Executivo). E há um espaço para a atuação judicial mais legítima.

Há situações, por exemplo, em que a política pública está prevista, mas não é cumprida, a exemplo de um medicamente que está na lista oficial, mas que não é entregue

\footnotetext{
${ }^{348}$ Ibidem, p. 146.

${ }^{349}$ Ibidem, p. 151.
} 
em determinada região. Neste caso, as decisões judiciais obrigariam "a implementação de uma política pública estabelecida globalmente, e que estava sendo descumprida (...), não houve a usual transformação dos cofres públicos em plano de saúde privado"350.

Neste passo, a crítica que se pretende ao Judiciário diz respeito à sua atuação para garantir diretamente, imediatamente e individualmente os direitos sociais, ignorando aspectos orçamentários e de políticas públicas. Isso não significa excluir o Judiciário do controle das políticas públicas. Como defende Virgílio Afonso da Silva, é possível defender um determinado ativismo judicial (legitimidade para discutir políticas públicas), desde que se entenda que esse ativismo é limitado por uma série de razões estruturais e que, portanto, exigem mudanças, especialmente nos procedimentos judiciais, para que passe a ser "possível tratar os direitos sociais e sobre eles decidir de forma coletiva" 351 .

Tratar de forma individual esses direitos sociais tem por consequência a destinação de recursos de determinada área para atender a ordem judicial. Assim, o problema dessas decisões que, por exemplo, concedem tratamentos de saúde de maneira individual, é que se pratica uma justiça comutativa e não distributiva; faz-se microjustiça e não macrojustiça ${ }^{352}$. Como observa Virgílio Afonso da Silva, as decisões individuais no ambito do direito à saúde mesmo que consigam "resolver" alguns casos isolados, em um cenário de recursos escassos, o dinheiro necessariamente será retirado de outros programas para atender as decisões judiciais.

Seguindo novamente pelo exemplo do medicamento, ao invés de distribui-los de forma irracional a indivíduos, o Judiciário deveria ser capaz de um "diálogo constitucional", controlando as políticas públicas através da exigência de "explicações objetivas e transparentes sobre a alocação de recursos públicos por meio das políticas governamentais, de forma a estar apto a questionar tais alocações com os poderes políticos sempre que necessário for" ${ }^{\text {,353. }}$.

\footnotetext{
${ }^{350}$ SCAFF, Fernando Facury. A efetivação dos direitos sociais no Brasil: garantias constitucionais de financiamento e judicialização. In: Fernando Facury Scaff; Roberto Romboli; Miguel Revenga. (Org.). A Eficácia dos Direitos Sociais - I Jornada Internacional de Direito Constitucional Brasil/Espanha/Itália. 1 ed. São Paulo: QuartierLatin, 2009, v. 1, p. 42.

${ }^{351}$ SILVA. Virgílio Afonso. O Judiciário e as políticas públicas: entre transformação social e obstáculo à realização dos direitos sociais. In: SOUZA NETO, Cláudio Pereira de; SARMENTO; Daniel. Direitos sociais: fundamentação, judicialização e direitos sociais em espécies. Rio de Janeiro: Lumen Juris, 2008, p. 596.

${ }^{352}$ SCAFF, Fernando Facury. Direito à saúde e os tribunais. In: NUNES, António José Avelãs; SCAFF, Fernando Facury. Os tribunais e o direito à saúde. Porto Alegre: Editora Livraria do Advogado, 2011.

${ }^{353}$ SILVA. Virgílio Afonso. O Judiciário e as políticas públicas: entre transformação social e obstáculo à realização dos direitos sociais. In: SOUZA NETO, Cláudio Pereira de; SARMENTO; Daniel. Direitos sociais: fundamentação, judicialização e direitos sociais em espécies. Rio de Janeiro: Lumen Juris, 2008, p. 597.
} 
Aqui, parece haver um ponto de encontro entre as formas de atuação do Judiciário, não apenas como mero garantidor de direitos individuais, mas como órgão capaz de exercer o controle das políticas públicas e das normas de Direito Financeiro.

É justamente essa a atuação que se poderia exigir, por exemplo, em face da inexecução orçamentária e do contingenciamento: são previstos programas sem destinação efetiva de recursos - por que não exigir transparência sobre as razões de não terem sido implementados os programas e se exigir realização de políticas públicas previstas em lei orçamentária? É justificável a inexecução da política pública? Essa atuação não resolverá o problema de muitos, mas o pressuposto aqui é que os recursos são escassos e haverá escolhas trágicas. Ao menos nessa linha, pode-se avançar no debate sobre a gestão dos recursos.

O que se quer chamar atenção é que a relação entre decisões judiciais e orçamento muitas vezes tem sido vista apenas através do debate sobre a possibilidade de garantia de direitos individuais, porém, pode ser muito mais adequada se for vista do aspecto do controle das normas orçamentárias.

Nessa linha, outra possibilidade de atuação judicial fora de uma perspectiva individual dos direitos refere-se ao controle de normas que tredestinam recursos. Se o Judiciário julga que uma norma que tredestinou recursos da saúde para outras áreas é ilegal/inconstitucional, e obriga que a previsão orçamentária seja cumprida (ou só permita destinação diversa nos casos autorizados pela Lei de Responsabilidade Fiscal), o direito à saúde passa a ser cada vez mais efetivo para uma coletividade, com observância do próprio orçamento.

Nesse último caso, compatibilizam-se a decisão política do Executivo e do Legislativo, quando da elaboração e aprovação do orçamento, e a efetividade aos direitos sociais, dentro de uma perspectiva coletiva. $\mathrm{O}$ direito fundamental funciona mais como parâmetro para o controle de constitucionalidade dos atos normativos do que como fim último e direto de um pleito individual.

J. J. Gomes Canotilho, analisando a jurisprudência portuguesa, observa a dificuldade de implementação, via tribunais, de direitos que ficam "dependentes, na sua exata configuração e dimensão, de uma intervenção legislativa conformadora e concretizadora, só então adquirindo plena eficácia". O referido autor também concorda que deve haver atuação do Judiciário, na perspectiva de "controlar se a actuação legislativa socialmente densificadora de direitos sociais se pauta por critérios reais de realização 
gradual (...) ${ }^{354}$. Trazendo essa consideração para o contexto que ora se analisa, pode-se pensar que a inexecução de políticas públicas (em um nível muito abaixo do que o previsto no orçamento) é um critério real de que não há realização gradual dos direitos sociais, violando, por exemplo, a vedação ao retrocesso social ${ }^{355}$. Nesse sentido, o ato que impede a execução (via de regra o contingenciamento) seria passível de apreciação pelo Poder Judiciário.

Portanto, prosseguir somente com um olhar individual para os direitos sociais, essencialmente coletivos, faz com que o Direito Financeiro sirva somente a quem possui instrumentos para movimentar o Poder Judiciário - “o que, de certa forma, apenas mantém o privilégio existente, privatizando o espaço público por meio de soluções individuais; é o alargamento do jardim". Por isso, defende-se que o Direito Financeiro não deve buscar alargar o jardim, ou seja, o espaço privado, mas “a praça [espaço público] deve se erguer acima das soluções individuais" $" 356$.

Retornando ao objeto desse estudo, a relação entre Judiciário e contingenciamento também pode se dar sob duas perspectivas: uma de intervenção judicial no orçamento (na programação do gasto) e outra de controle da norma.

Quanto à primeira, tem-se que um aumento na concessão individual de direitos sociais via Judiciário, independentemente da previsão orçamentária, em certa medida, estimulará o uso do contingenciamento. Ora, se é necessário destinar recursos para finalidades não previstas no orçamento (porque houve decisão judicial), é certo que parte das despesas previstas não será executada. Por isso, haverá uma tendência de mais contingenciamentos quanto mais despesas imprevistas forem criadas pelo Poder Judiciário.

Quanto à segunda perspectiva, entende-se positiva que haja um controle do Judiciário sobre as normas orçamentárias, dentre as quais as relativas ao contingenciamento. Mostrou-se que é possível a atuação do Judiciário em face das leis

\footnotetext{
${ }^{354}$ CANOTILHO, J. J. Gomes. Direito Constitucional e Teoria da Constituição. $7^{\mathrm{a}}$ ed. Coimbra: Almedina, 2003, p. 520.

${ }^{355}$ Sobre o tema, vide TAVEIRA, Christiano de Oliveira; MARÇAL, Thaís Boia. Proibição do retrocesso social e orçamento: em busca de uma relação harmônica. Revista de Direito Administrativo, Rio de Janeiro, v. 264, set./dez. 2013. DEBRLI, Felipe. A aplicabilidade do princípio da proibição do retrocesso social no Direito Brasileiro. In SOUZA NETO, Claudio Pereira; SARMENTO, Daniel (coords.). Direitos Sociais: Fundamentos, Judicialização e Direitos Sociais em espécie. Rio de Janeiro: Editora Lumen Juris, 2010. SARLET, Ingo Wolfgang. Proibição de retrocesso, dignidade da pessoa humana e direitos sociais: manifestação de um constitucionalismo dirigente possível. In: Revista Eletrônica sobre a Reforma do Estado (RERE), Salvador, Instituto Brasileiro de Direito Público, $\mathrm{n}^{\circ}$ 15, setembro/outubro/novembro de 2008. Disponível em www.direitodoestado.com.br/rere.asp. Acesso em 28/02/2014.

356 SCAFF, Fernando Facury. O Jardim e a Praça ou a Dignidade Humana e o Direito Tributário e Financeiro. In: Heleno Taveira Tôrres. (Org.). Direito e Poder - Nas Instituições do Público e do Privado Contemporâneos - Estudos em Homenagem a Nelson Saldanha. São Paulo: Manole, 2005, p. 555.
} 
orçamentárias. Deve-se ter extrema cautela quando essa atuação envolvem pleitos individuais de direitos sociais. Porém, vê-se com bons olhos quando a atuação se dá a partir de uma perspectiva coletiva, envolvendo o controle de atos em face dos direitos sociais ou em face do próprio cumprimento das normas orçamentárias. Essa última perspectiva é que se admite como possível em relação ao contingenciamento. E diante disso questiona-se: esse controle em face do contingenciamento é, de alguma forma, feita pelo Judiciário brasileiro? É o que se pretende verificar no tópico seguinte.

\subsubsection{Controle judicial do contingenciamento: análise de casos}

Partindo das premissas acima fixadas, foi realizado um levantamento de dados na jurisprudência dos Tribunais Superiores, a partir do termo "contingenciamento",357. Desde logo, ressalta-se que se observou um controle muito tímido desse instrumento de flexibilização orçamentária.

No âmbito do Supremo Tribunal Federal, foram obtidos quatro resultados para acórdãos. Entretanto, apenas dois julgados têm pertinência com o tema ${ }^{358}$ : trata-se da Ação Direta de Inconstitucionalidade $n^{\circ}$ 2.153/ES e da Ação Direta de Inconstitucionalidade $n^{\circ}$ 2.022/ES.

\footnotetext{
${ }^{357}$ Metodologia utilizada: a pesquisa foi feita no âmbito do Supremo Tribunal Federal, Superior Tribunal de Justiça e Tribunais Regionais Federais, sempre utilizando apenas a palavra-chave "contingenciamento" para a pesquisa de acórdãos (de modo a excluir decisões monocráticas ou outros atos). A pesquisa foi feita em 17/03/2014, nos sítios do STF (http://www.stf.jus.br/portal/jurisprudencia/pesquisarJurisprudencia.asp), STJ (http://www.stj.jus.br/SCON/) e no portal de pesquisa unificada da Justiça Federal (http://www.jf.jus.br/juris/unificada), sendo neste último selecionados apenas os Tribunais Regionais Federais.

${ }^{358}$ Em um dos casos a palavra contingenciamento (bem como "contingenciado" e "contingenciar") aparece no texto relacionada à "reserva de contingência". Trata-se do caso em que se discutia a constitucionalidade de destinação da CIDE-combustíveis para outra finalidade que não a constitucionalmente prevista. Um dos argumentos dos autores da Ação era de que os recursos da CIDE estavam sendo destinados para a reserva de contingência (cerca de $40 \%$ segundo consta do acórdão), o que representaria violação à norma constitucional que prevê destinação específica para tais recursos. Em alguns trechos do julgado, os Ministros denominam de "recursos contingenciados", os recursos da CIDE destinados para a reserva de contingência. Não se trata, portanto, de contingenciamento no sentido de limitação de empenho e movimentação financeira. (BRASIL. Supremo Tribunal Federal. Pleno. ADI 2.925/DF. Relatora Ministra Ellen Gracie. Relator para acórdão Ministro Marco Aurélio. Julgamento 19/12/2003).

Em outro julgado, o termo "contingenciamento", embora estivesse se referindo a uma retenção de recursos, tampouco estava sendo utilizado no mesmo sentido que aqui se trata, ou seja, como limitação de empenho e movimentação financeira durante a execução orçamentária. Trata-se do julgamento da Emenda Constitucional $n^{\circ} 62 / 09$, que instituiu um regime especial de pagamento de precatórios e determinava que os entes constituíssem uma espécie de reserva de recursos (em percentuais da receita corrente líquida) para pagamento de precatórios. Essa reserva de recursos foi, no julgado do STF, denominada contingenciamento de recursos para pagamento de precatórios. (BRASIL. Supremo Tribunal Federal. Pleno. Ação Direta de Inconstitucionalidade no 4.425/DF. Relator Ministro Ayres Britto. Julgamento em 14/03/2013).
} 
Ambas as ações envolviam a mesma discussão, qual seja, a declaração de inconstitucionalidade de lei do Estado do Espírito Santo que determinava a retenção de salários de funcionários públicos por meio do contingenciamento de despesas. Inicialmente, houve suspensão da lei por decisão na $\mathrm{ADI} \mathrm{n}^{\circ}$ 2.022. A lei foi revogada e nova lei foi instituída com a mesma disposição, advindo o julgamento de medida cautelar na $\mathrm{ADI} \mathrm{n}^{\circ}$ 2.153. A decisão, por unanimidade, foi pela inconstitucionalidade da lei (julgamento em sede cautelar ${ }^{359}$ ), especialmente em razão, segundo voto do Relator Ministro Ilmar Galvão, de que "o contingenciamento, nos moldes do referido diploma legal, estabelece retenção que importa o pagamento de valores inferiores ao quantum nominal dos vencimentos (...) violando o princípio da irredutibilidade dos vencimentos" ${ }^{\text {}}{ }^{60}$.

De se notar que houve a declaração de inconstitucionalidade de um contingenciamento, em razão da violação de princípios constitucionais. Embora não envolvesse os vícios a que se aludiu nos capítulos anteriores, o Supremo Tribunal Federal exerceu o controle sobre uma hipótese de contingenciamento, mediante a verificação de afronta a princípios constitucionais, no caso o princípio da irredutibilidade de vencimentos $^{361}$.

No âmbito do Superior Tribunal de Justiça, utilizando-se o mesmo método já descrito, a pesquisa do termo "contingenciamento" gerou nove resultados. Porém, apenas em dois casos a palavra possui relação com a limitação de empenho e movimentação financeira na execução orçamentária ${ }^{362}$. Em um desses casos, o termo aparece meramente

\footnotetext{
${ }^{359}$ Após julgamento em sede cautelar, a lei do Estado do Espírito Santo foi novamente revogada. Por essa razão, a Ação perdeu seu objeto, foi extinta e arquivada pelo Supremo Tribunal Federal.

${ }^{360}$ BRASIL. Supremo Tribunal Federal. Ação Direta de Inconstitucionalidade. Medida Cautelar. ADI ${ }^{\circ}$ 2.153/ES. Relator Ministro Ilmar Galvão. Julgamento em 16/08/2000.

${ }_{361}$ É preciso ressalvar que a possibilidade de controle concentrado de constitucionalidade do contingenciamento remete, novamente, à discussão da necessidade ou não de que o ato tenha efeitos genéricos e abstratos, como já exposto, e também discussão sobre seu "caráter normativo". Tal tema ainda não está plenamente definido na jurisprudência do STF, sendo que a alegação de inconstitucionalidade do contingenciamento, no âmbito do controle concentrado, certamente passaria antes pela discussão de sua possibilidade e pela natureza e efeitos do ato. De se mencionar, ainda, que o STF já admitiu o controle concentrado de um "ato administrativo com caráter genérico e abstrato", conforme se verifica do trecho da seguinte ementa: “(...) 3. Ato administrativo com caráter genérico e abstrato. Possibilidade de controle concentrado de constitucionalidade. Precedentes." (BRASIL. Supremo Tribunal Federal. Pleno. Ação Direta de Inconstitucionalidade $n^{\circ}$ 3.401/SP. Relator Ministro Gilmar Mendes. Julgamento em 26/04/2006).

${ }^{362}$ Nos outros casos, o termo contingenciamento não aparece em seu sentido técnico-jurídico. Aparece, por exemplo, como sinônimo de estabelecer um "contingente" (porção de trabalhadores para que uma greve no serviço público não seja considerada abusiva). Por exemplo, nesse trecho: "a paralisação das atividades dos servidores (...), sem o contingenciamento do mínimo de pessoal necessário à realização das atividades essenciais, (...), atenta contra o Estado Democrático de Direito (...)"(BRASIL. Superior Tribunal de Justiça. Primeira Seção. Agravo Regimental na Petição n 7.933. Relator Ministro Castro Meira. Julgamento em 23/06/2010).
} 
de forma incidental ${ }^{363}$, enquanto que no outro é de fato objeto do julgado. Este último é o Agravo Regimental na Suspensão de Liminar de Sentença $\mathrm{n}^{\mathrm{o}} 1.120 / \mathrm{SP}^{364}$, no qual, a partir de ação civil pública proposta pelo Ministério Público Federal em face da União, questionou-se o contingenciamento de valores Fundo Nacional de Segurança e Educação no Trânsito.

Em primeira instância, o Ministério Público Federal obteve sentença favorável, determinando à União repassar e aplicar efetivamente os valores do referido fundo dentro de 30 dias. O Tribunal Regional Federal da $3^{\text {a }}$ Região determinou a suspensão da decisão e, após recurso, os autos foram ao Superior Tribunal de Justiça. Interessante notar os argumentos expostos de ambos os lados, o que demonstra os conflitos que se têm abordado nesse trabalho. Alega o Ministério Público Federal, conforme extraído do próprio acórdão:

A União, ilegalmente, vem retendo recursos que deveriam ser aplicados em programas de prevenção de acidentes e projetos de educação e segurança no trânsito visando a acumular recursos em caixa para atingir as metas de superávit primário. É inaceitável colocar essa meta acima de valores constitucionais como a vida e a saúde.

De outro lado, defende-se a União, conforme argumento acolhido pelo Superior Tribunal de Justiça, que:

Sem dúvida, os valores são muito altos, podendo, sim, afetar negativamente o superávit primário (...) Os recursos obtidos com o superávit primário, por outro lado, são utilizados para o pagamento dos juros da dívida pública e da própria dívida quando possível, viabilizando maiores investimentos pelo Estado. Essa operação é essencial, portanto, para a economia pública, sobretudo neste momento conturbado do mercado financeiro mundial, em que os investimentos revelam-se tímidos. Seguindo essa linha de raciocínio, com toda a certeza, o controle da economia na atualidade será positivo para o futuro da saúde e da segurança públicas e para os demais investimentos sociais e em infraestrutura, devendo-se preservar, com responsabilidade e diante do contexto econômico vigente, a possibilidade de bloqueio de determinadas despesas, e em determinados valores pela União com o propósito de evitar danos futuros à economia, à saúde pública, às políticas sociais, ao crescimento e ao desenvolvimento do País. Ademais, as campanhas de educação no trânsito não estão suspensas. Mesmo em volume inferior ao

O termo aparece também em julgados sobre a legalidade do Decreto $\mathrm{n}^{\mathrm{o}} 1.519 / 95$, que estabeleceu limitações no pagamento de "retribuições" aos servidores da CVM e da SUSEP. Porém, tampouco como sinônimo de limitação de empenho na execução orçamentária, razão pela qual também não serão analisados.

363 No Recurso em Mandado de Segurança $n^{\circ} 32.521 /$ RO, o contingenciamento é apenas referido incidentalmente. Trata-se de caso em que um candidato aprovado em concurso público questiona sua não nomeação dentro das vagas previstas. O contingenciamento ilegal pelo Executivo é um dos argumentos mencionados pelo Ministério Público para justificar a não nomeação, porém, tal argumento, vez que não comprovado, não foi analisado pelo acórdão. (BRASIL. Superior Tribunal de Justiça. Recurso em Mandado de Segurança no 32.521/RO. Primeira Turma. Relator Ministro Benedito Gonçalves. Julgado em 01/09/2011).

${ }^{364}$ BRASIL. Superior Tribunal de Justiça. Corte Especial. Agravo Regimental na Suspensão de Liminar de Sentença $n^{\circ}$ 1.120/SP. Relator Ministro Cesar Asfor Rocha. Julgamento em 18/08/2010. 
que se poderia eventualmente dispor, os gastos com propagandas educativas em jornais, televisões e placas nas ruas continuam, além da fiscalização efetuada diretamente pelos agentes públicos. Por último, a União bem lembrou em sua inicial que não haverá prejuízo irreparável ao DENATRAN, destinatário legal dos recursos, pois o contingenciamento não desfaz a vinculação da receita para o órgão, podendo, no futuro, ser utilizada nos projetos definidos na lei'. A propósito, sobre o tema, o parágrafo único do art. $8^{\circ}$ da Lei de Responsabilidade Fiscal ( $\mathrm{LC}^{\circ} 101$, de 4.5.2000) é claro ao impor que "os recursos legalmente vinculados à finalidade específica serão utilizados exclusivamente para atender ao objeto de sua vinculação, ainda que em exercício diverso daquele em que ocorrer o ingresso.

Interessante notar dois aspectos na argumentação do Tribunal: de um lado, há uma preocupação com as implicações políticas e econômicas da intervenção judicial no orçamento; de outro lado, o contingenciamento está, no caso, afetando valores vinculados e já arrecadados e, embora, o contingenciamento não necessariamente tredestine despesas para os fins originalmente previstos, nesse caso, parece ser este justamente o objetivo da União com o contingenciamento, até porque, um dos argumentos é o direcionamento desses valores para formação do superavit primário e pagamento dos juros da dívida. Nesse sentido, essa aplicação do contingenciamento seria ilegal, ao menos pela tredestinação de recursos vinculados.

Destaca-se o voto condutor do acórdão, que afirma ser a discussão sobre receitas que devem ser destinadas ao Fundo Nacional de Segurança e Educação no Trânsito, o qual é formado por "10\% (dez por cento) do total dos valores arrecadados destinados à Previdência Social, do Prêmio do Seguro Obrigatório de Danos Pessoais causados por Veículos Automotores de Via Terrestre - DPVAT" e pela "receita arrecadada com a cobrança das multas de trânsito". Ou seja, discute-se a aplicação de receitas arrecadadas para pagamento de juros da dívida.

Reconhece-se, novamente, que o pagamento de juros e a geração de superavit primário são relevantes para a economia, mas, repisa-se, há limites na aplicação do contingenciamento para essa finalidade. Se há um fundo formado por percentuais de receitas arrecadadas, não há outra possibilidade que não a de aplicar tais valores para o fim legalmente ou constitucionalmente previsto.

Passa-se, por fim, ao âmbito dos Tribunais Regionais Federais. Utilizando-se o mesmo método, a pesquisa com a palavra-chave "contingenciamento" apontou para o seguinte: 19 resultados no TRF da $1^{\text {a }}$ Região, 15 resultados no TRF da $2^{\mathrm{a}}$ Região, 10 resultados no TRF da $3^{\text {a }}$ Região, 3 resultados no TRF da $4^{\text {a }}$ Região e 4 resultados no TRF 
da $5^{\text {a }}$ Região ${ }^{365}$. Novamente, os acórdãos selecionados trouxeram tanto o termo no sentido técnico-jurídico que se busca - limitação de empenho e movimentação financeira na execução orçamentária -, quanto em outros sentidos, não técnicos e não relacionados à execução orçamentária.

De uma maneira geral, não se verificou no âmbito dos Tribunais Regionais Federais casos de controle sobre o contingenciamento. O termo, quando aparece no sentido buscado, é porque está sendo utilizado pelo Poder Público como argumento para justificar um descumprimento contratual (a exemplo de financiamentos da Caixa Econômica Federal e do BNDES) ou para justificar os efeitos negativos sobre as finanças públicas de uma decisão desfavorável à União. Explica-se, mencionando os casos encontrados.

No âmbito do Tribunal Regional Federal da $1^{\mathrm{a}}$ Região, apenas três decisões trouxeram o termo no contexto ora estudado. Em dois dos casos, o contingenciamento está mencionado para alegar prejuízo às contas públicas provocadas por uma determinada decisão, desfavorável à União, e que por essa razão deveria ser revista.

Em um dos casos, por meio de Agravo de Instrumento ${ }^{366}$, a União conseguiu reduzir multa a que foi condenada, dentre outras razões, porque a multa que havia sido imposta pelo descumprimento da decisão revelou-se "atentatória à economia pública". Esse ponto foi defendido a partir da decorrente necessidade de contingenciamento: a “fixação de multa em valor elevado e sem limitação constitui ônus excessivo ao Poder Público e à coletividade, impõe o contingenciamento e o remanejamento de recursos financeiros, em detrimento de outras políticas públicas de alta prioridade".

Na mesma linha, no julgamento de um Agravo Regimental em Suspensão de Segurança ${ }^{367}$, o contingenciamento constou como argumento de defesa da União contra liminar concedida que suspendia a cobrança da CPMF. O argumento foi acatado nos seguintes termos: "Evidente o impacto financeiro a ser causado pela decisão, com consequente desequilíbrio nas contas públicas em face do recente contingenciamento orçamentário de, aproximadamente, $48 \%$ (quarenta e oito por cento)".

\footnotetext{
${ }^{365}$ Pesquisa com o termo "contingenciamento" nos Tribunais Regionais Federais, através do link pesquisa unificada do Portal da Justiça Federal (http://www.jf.jus.br/juris/unificada). Pesquisa em 17/03/2014.

366 BRASIL. Tribunal Regional Federal da $1^{\text {a }}$ Região. Quinta Turma. Agravo de Instrumento $\mathrm{n}^{\circ}$ 200901000547643. Relator Desembargadora Federal Selene Maria de Almeida. Julgado em 03/11/2010.

${ }^{367}$ BRASIL. Tribunal Regional Federal da $1^{\text {a }}$ Região. Corte Especial. Agravo Regimental na Suspensão de Segurança no 200201000263734. Relator Desembargador Federal Catão Alves. Julgado em 19/09/2002.
} 
Ainda no âmbito do Tribunal Regional Federal da $1^{a}$ Região, o terceiro caso relacionado ao tema refere-se ao julgamento de Apelação Cível ${ }^{368}$, no qual o contingenciamento foi apontado para justificar o descumprimento contratual pela Caixa Econômica Federal no âmbito de um contrato de financiamento. O Tribunal entendeu, entretanto, por condenar a Caixa, sob o fundamento de que a existência de contingenciamento não permite o descumprimento contratual: "comprovado nos autos que a ré deixou de repassar os recursos do financiamento pactuado, nas épocas aprazadas, do que resultou atraso no cronograma de execução da obra financiada, induvidoso o nexo causal entre o fato do contingenciamento dos recursos e os prejuízos experimentados pela autora".

No Tribunal Regional Federal da $4^{\mathrm{a}}$ Região e no Tribunal Regional Federal da $3^{\mathrm{a}}$ Região, nenhuma das decisões envolvia a discussão sobre a legalidade ou constitucionalidade do contingenciamento no sentido que aqui se trata, razão pela qual não importa mencioná-las.

Nos demais Tribunais ( $2^{\mathrm{a}}$ e $5^{\mathrm{a}}$ Região), verificam-se decisões semelhantes àquelas do Tribunal Regional Federal da $1^{\mathrm{a}}$ Região, as quais se faz rápida referência.

No âmbito do Tribunal Regional Federal da $5^{\mathrm{a}}$ Região, dos quatro resultados, em três casos o termo aparecia no sentido de limite de empenho e movimentação. Os casos também tratavam de relações de financiamento envolvendo a Caixa Econômica Federal que, acusada de descumprimento de contrato, alegava como um dos motivos para tal o contingenciamento de recursos determinado pelo Ministério. Em um dos casos, a decisão foi no sentido de que a modificação contratual decorrente do contingenciamento não alterou a equação econômico-financeira do contrato e, por isso, não foi efetivamente rejeitado $^{369}$. Nos outros dois casos, o contingenciamento não foi acolhido como motivo para justificar o descumprimento contratual, sem maiores considerações acerca do instituto $^{370}$.

Igualmente, no Tribunal Regional Federal da $2^{\mathrm{a}}$ Região, constatou-se um caso com utilização do termo no sentido ora analisado, mais uma vez tratando de relação contratual

\footnotetext{
${ }^{368}$ BRASIL. Tribunal Regional Federal da $1^{\text {a }}$ Região. Sexta Turma. Apelação Cível no 199901000869084. Relator Desembargador Daniel Paes Ribeiro. Julgado em 24/06/2002.

${ }^{369}$ BRASIL. Tribunal Regional Federal da 5a Região. Quarta Turma. Apelação Cível no 200905000342949.

Relator Desembargador Federal Frederico Dantas. Julgado em 15/12/2009.

370 Trata-se dos seguintes casos: BRASIL. Tribunal Regional Federal da $5^{\text {a }}$ Região. Terceira Turma. Apelação Cível $n^{\circ}$ 200405000100087. Relator Desembargador Federal Paulo Roberto de Oliveira Lima. Julgado em 22/11/2007.

BRASIL. Tribunal Regional Federal da 5 Região. Primeira Turma. Apelação Cível no 200605000581359. Relator Desembargador Federal Francisco Wildo. Julgado em 09/08/2007.
} 
em financiamentos. No julgado, o contingenciamento foi argumento do BNDES para justificar descumprimento de contrato. A decisão novamente foi no sentido de não se acolher o argumento do órgão público ${ }^{371}$.

O que se pode notar da pesquisa realizada é que o contingenciamento no âmbito dos Tribunais Regionais Federais apareceu tão somente de forma incidental, usualmente como argumento do Poder Público.

Não se aprofundará a busca no âmbito dos Tribunais de Justiça, especialmente porque não se tem a pretensão de fazer uma revisão jurisprudencial do tema, mas apenas verificar se existe o controle judicial do contingenciamento, mormente em âmbito federal. Uma pesquisa nos Tribunais de Justiça escaparia a tal objetivo, seja pelo número de resultados, seja pelo foco do trabalho.

De qualquer forma, o levantamento de dados feito neste capítulo serviu para demonstrar que ainda é tímido o controle judicial sobre o contingenciamento, possivelmente também por falta de provocação. Isso não significa que ele não possa ocorrer. Há possibilidade de se identificar ilegalidades e inconstitucionalidades no decreto de contingenciamento, e a prática traz fortes indícios de que essas de fato ocorrem.

É bem verdade que declarar o contingenciamento ilegal ou inconstitucional não é uma decisão simples de ser implementada. Poderia representar, inclusive, uma crise entre os Poderes. Reconhecem-se também as dificuldades processuais - por exemplo, se controle concentrado ou difuso.

No entanto, já que as críticas e os problemas são recorrentemente apontados, e de fato existem, há que se avançar no controle desse instrumento. Não existe uma solução fácil para um problema tão complexo, mas alguns caminhos possíveis seriam: exigir esclarecimentos sobre os motivos dos reiterados contingenciamentos (por certo, vinculado ao que determina o artigo $9^{\circ}$ da Lei de Responsabilidade Fiscal); exigir transparência sobre os critérios de "liberação" e "bloqueio" dos recursos feito pelo contingenciamento, especialmente em face da previsão do artigo $9^{\circ}, \S 1^{\circ}$ da Lei de Responsabilidade Fiscal; exigir informações e justificativas para a não aplicação de recursos ou de aplicação insuficiente de recursos em programas previstos no orçamento (mromente quando por anos seguidos).

Sobre este último ponto, verifica-se que o Judiciário, majoritariamente, entende que o contingenciamento não é motivo para justificar o descumprimento de um contrato (de

\footnotetext{
${ }^{371}$ BRASIL. Tribunal Regional Federal da $2^{a}$ Região. Primeira Seção. Embargos Infringentes em Apelação Cível no 9702322464. Relator Desembargadora Federal Julieta Lidia Lunz. Julgado em 13/06/2002.
} 
financiamento, por exemplo). De outra parte, será que sempre o contingenciamento será motivo para justificar o descumprimento das políticas públicas e programas previstos na lei orçamentária? Obviamente há uma diferença na complexidade das duas situações, mas é inegável a necessidade de impor limites jurídicos na aplicação do contingenciamento.

Por fim, algumas propostas de controle também são indicadas por Élida Graziane Pinto, em sua análise sobre o financiamento dos direitos fundamentais. Citam-se duas delas, que teriam impacto direto no controle do contingenciamento:

Ajuizar ações populares para invalidar os atos (decretos) de contingenciamento preventivo de despesas que não estejam calcados nos motivos de fato e de direito admitidos em lei, a partir do que será possível questionar a consecução de superávits primários com base na inexecução arbitrária da lei do orçamento.

Requerer - no curso dos processos administrativos federais de execução orçamentária, na forma do que dispõem os arts. $2^{\circ}$, VII e 50, I da Lei $n^{\circ}$ 9.784/99 - a elucidação dos motivos do contingenciamento de despesas, já que haveria afetação de interesses inscritos na LOA e a apresentação do resultado da avaliação dos programas de ação governamental, tal como o exigem o art. 74 , I da CR/1988 e o art. 75, III da Lei $\mathrm{n}^{\circ}$ $4.320 / 64^{372}$.

Com intervenções nesse sentido, imagina-se, as previsões orçamentárias passariam a ser tratadas de forma mais séria, mais próximas da realidade e com mais densidade normativa. Se o Judiciário está incluído no controle das políticas públicas e do orçamento, então que atue para a aplicação de políticas públicas globais e pela inaplicação de atos que violem as normas de Direito Financeiro. Essas considerações vão ao encontro do que se entende ser uma intervenção mais adequada do Judiciário sobre o orçamento, tal como tratado no presente capítulo.

372 PINTO, Élida Graziane. Financiamento de Direitos Fundamentais: políticas públicas vinculadas, estabilização monetária e conflito distributivo no orçamento da União do pós-Plano Real. Belo Horizonte: Editora O Lutador, 2010, p. 390. 


\section{CONCLUSÕES}

Após o advento da democracia, com a Constituição Federal de 1988 e as amplaição das normas de Direito Financeiro (em nível constitucional e infraconstitucional), o estudo das Finanças Públicas tem enfrentado um novo desafio: a concretização das normas de Direito Financeiro. É nesse debate que se insere o presente trabalho, que pretendeu pensar em que medida as normas de Direito Financeiro têm sido respeitadas e contribuído para avanços institucionais e sociais; refletir se o Direito Financeiro tem tido força normativa suficiente para se impor frente aos interesses políticos e econômicos, pessoais e privados e dar maior rumo na gestão de recursos públicos. Por trás das discussões trazidas no presente estudo residem os questionamentos acerca da possibilidade de o Direito provocar mudanças na sociedade ou, ainda, como resume sociólogo Boaventura de Sousa Santos: “poderá o direito ser emancipatório? Ou: será que existe uma relação entre o direito e uma demanda por uma sociedade boa?"373.

Tais questões não podem deixar de ser pensadas levando em conta um novo paradigma para o Direito Financeiro, decorrente de sua constitucionalização e da relação entre orçamento e direitos fundamentais. Dentro desse novo paradigma, renovaram-se os desafios do Direito Financeiro, passando-se a encarar o orçamento como meio de dar efetividade à Constituição, em especial como instrumento de implementação do Estado Democrático de Direito e dos direitos fundamentais.

A partir de um corte metodológico, esses desafios foram enfrentados em um campo específico: a execução orçamentária e o contingenciamento, especialmente por se entender que se trata de momento crucial na concretização do Direito Financeiro, com inúmeras implicações para o gasto público. Esse o contexto que se inesriu este tabalho, que agora se conclui.

Primeiramente, há que se destacar que o contingenciamento é um instrumento de flexibilização orçamentária que possui parâmetros jurídicos a serem observados para sua aplicação. Além da observância dos mais diversos aspectos da elaboração e da execução orçamentária, há um pressuposto específico para sua utilização: o risco de não realização de receitas que ameace o cumprimento das metas fiscais, conforme previsão do caput do artigo $9^{\circ}$ da Lei de Responsabilidade Fiscal.

\footnotetext{
${ }^{373}$ SANTOS, Boaventura de Sousa. Poderá o direito ser emancipatório? In: Revista Crítica de Ciências Sociais, 65, Maio de 2003: 3-76. Disponível em http://www.boaventuradesousasantos.pt/media/pdfs/podera_o_direito_ser_emancipatorio_RCCS65.PDF. Acesso em 21/03/2014.
} 
Essa disposição mostra não apenas que existe um requisito específico para que a despesa pública prevista em lei não seja executada, mas denota também que se não verificada faticamente essa hipótese, será obrigatória a execução orçamentária ou, de outra parte, ilegal o decreto de contingenciamento.

Além de um requisito específico, outros parâmetros jurídicos também informam a aplicação do contingenciamento, dentre os quais (i) a necessidade de que, uma vez restabelecida a receita, as recomposições das dotações devem ser proporcionais; e (ii) a impossibilidade de contingenciamento das denominadas obrigações constitucionais e legais, além das destinadas ao serviço da dívida.

Se não há dúvidas de que existem limites jurídicos para a aplicação do contignenciamento, de outro lado, há dificuldades em ser verificar a observância desses limites na prática. A doutrina e os meios de comunicação já apontavam inúmeros indícios sobre uma prática do contingenciamento desvinculada de seus parâmetros jurídicos. Complementando a revisão bibliográfica, o levantamento de dados da execução orçamentária dos últimos quatro anos (2010 a 2013) deu mais um passo na análise do contingenciamento.

A partir dos dados apresentados, verifica-se um comportamento na execução orçamentária federal que confirma as suspeitas levantadas pela doutrina: enquanto a realização das receitas fica aproximadamente de $10 \%$ a $15 \%$ abaixo do previsto pela Lei Orçamentária Anual, a execução de despesas discricionárias fica quase 50\% abaixo do previsto na lei. Com pequena variação, esse comportamento se repetiu nos anos analisados, e demonstra um desajuste entre a previsão orçamentária e a pretensão de execução de despesas discricionárias. Menciona-se, por exemplo, que no ano em que a arrecadação mais se aproximou da previsão, foi menor o percentual de execução de despesas discircionárias; ao passo que no ano em a arrecadação mais se distanciou da previsão, foi maior o percentual de execução de despesas discircionárias.

Além do quadro geral, a situação mostra-se ainda mais problemática quando se olha para alguns órgãos do Poder Executivo, extremamente prejudicados pelo contingenciamento, com inexecução da ordem de $80 \%$ de seu orçamento de despesas discricionárias. O problema não está apenas no percentual elevado, mas também na ausência de proporcionalidade entre as limitações e liberações de recursos. Não é possível fazer nenhuma previsão se o órgão será ou não comtemplado pela liberação de recursos ao longo do exercício, mesmo que tenha sido atingido por um contingenciamento no início do 
ano. Inexiste critérios claros para os remanejamentos feitos unilateralmente pelo Executivo na Lei Orçamentária aprovada pelo Legislativo.

Ademais, os desajustes encontrados na execução orçamentária espelham a ampla possibilidade de não realização de políticas públicas (ou adiamento ou parcial execução) ao passo que a obtenção de superavit primário continua como objetivo prioritário a ser alcançado (por vezes superado). É bem verdade que os superavits primários são indicadores importantes para a política fiscal e para o controle da dívida pública, porém, significa que menos recursos estão sendo empregados na execução orçamentária dos demais órgãos e programas, ou seja, nas políticas públicas. Há um conflito nas decisões orçamentárias, que nem sempre está claro nos processos decisórios do orçamento. Aliada à falta de critérios para o contingenciamento e liberação de recursos, esse debate está afastado dos mecanismos democráticos e de controle.

Se a investigação empírica e os dados trazidos ao presente trabalho não possibilitam uma conclusão numericamente precisa sobre os impactos do contingenciamento na execução orçamentária, especialmente diante das inúmeras variáveis, conflitos de dados, diversas fontes de informações e classificação, seguramente permitem avançar na discussão de problemas que já eram apontados pela doutrina. Aliás, não apenas no aspecto quantitativo, verifica-se que os problemas na inexecução orçamentária decorrente do forte impacto do contingenciamento se traduz também em aspectos relevantes do gasto público..

Em primeiro lugar, verificam-se prejuízos na realização de políticas públicas. Se o orçamento previsto não é cumprido, é certo que muitos programas deixam de ser executados integralmente, sendo que parte das políticas previstas pela lei orçamentária não recebem qualquer recurso. É comum comum verificar programas sem qualquer execução ou com execução de apenas pequena parte do autorizado ou, ainda, com execução somente de restos a pagar.

Em segundo lugar, há prejuízos quanto ao planejamento do gasto público. É visível que o Executivo não se compromete com a programação da lei orçamentária. Se o "planejamento de curto prazo", consubstanciado na lei orçamentária anual, não é observado, haverá ainda menos chances de respeito aos planejamentos de médio ou longo prazo. A situação é mais grave se lançado um olhar para os órgãos do Executivo. Uma vez que não há proporcionalidade nem critérios no contingenciamento e descontingenciamento, não se sabe quais e quando os órgão serão contemplados pela liberação de recursos. É comum a liberação de recursos no final do ano, sem tempo hábil para execução, o que aumenta a quantidade de restos a pagar que, por decorrência, prejudicará o planejamento 
dos anos seguintes. Portanto, com a execução orçamentária afetada intensa e reiteradamente pelo contingenciamento, impossível a concretização de qualquer planejamento.

Em terceiro lugar, a mencionada ausência de critérios representa um problema para transparência do gasto público. Com os seguidos contingenciamentos e descontingenciamentos, sem observência de proporcionalidade, dificulta-se o acompanhamento do gasto.

Por fim, os reitados contingenciamentos, em conjunto com outros instrumentos de flexibilização orçamentária, permitem remanejamentos unilaterais pelo Executivo e, portanto, distorcem o orçamento aprovado pelo Legislativo. Ademais, aliado à falta de transparência, dificulta-se o exercício de controle pelos demais Poderes e a garantia de que haja mais legitimidade democrática ao gasto público.

Todos esses efeitos confirmam a hipótese levantada inicialmente de que a prática relacionada ao contingenciamento é um dos entraves para uma maior concretização do Direito Financeiro, pelos prejuízos aos diversos aspectos do gasto público.

São evidentes, portanto, os problemas decorrentes da utilização do contingenciamento sem observância de seus parâmetros legais. E um dos motivos para que essa prática seja reiterada (quase "institucionalizada") é o frágil controle exercicido sobre o Executivo no âmbito da execução orçamentária. A despeito de existirem instituições com competência para exercer o controle jurídico sobre o contingenciamento, o que se verifica é que este ainda é bastante tímido ou pouco efetivo. Há uma percepção dos três principais órgãos de controle (Tribunal de Contas, Poder Legislativo e Poder Judiciário) de que há problemas relativos ao uso do contingenciamento, porém, com poucas consequências práticas.

No Tribunal de Contas da União, a partir dos relatórios de gestão, há uma percepção dos prejuízos dos reiterados contingenciamento sobre o planejamento dos órgão orçamentários e a concretização das políticas. Há, ainda, recomendações desse Trbiunal para diminuir as limitações de movimentação e empenho durante a execução orçamentária, bem como para melhorar os critérios de uso do contingeniamento. Porém, do que se vê tais recomendações ainda não geraram um efeito prático. É preciso que o Tribunal de Contas se utilize de outros instrumentos para exigir uma melhor aplicação do contingenciamento, a exemplo da emissão de alertas, usual nos casos de descumprimento dos limites de dívida e de despesas com pessoal. 
No âmbito do Legislativo, embora haja a competência para apreciar relatórios sobre a execução dos planos de governo e de fiscalizar e controlar os atos do Poder Executivo, o que se verifica é o amplo domínio do Poder Executivo na execução do orçamento. Não apenas inexiste controle do Legislativo sobre o contingenciamento, mas o próprio contingenciamento é utilizado pelo Executivo para controlar politicamente o Legislativo. Há propostas normativas de tornar o orçamento impositivo e de exigir justificativas para a inexecução orçamentária, o que seria desejável e reforçaria a atuação do Legislativo. Porém, os projetos com tramitação mais avançada estão voltados unicamente para reforçar a atuação do Legislativo no tocante às emendas parlamentares, e não ao orçamento como um todo.

Por fim, no âmbito do Judiciário, nota-se uma evolução no controle de legalidade e constitucionalidade das leis orçamentárias, mas essa evolução ainda não avançou sobre outros atos, tal como os decretos de contingenciamento. O controle do Judiciário seria relevante, inclusive como forma de exigir motivação, transparência e critérios para os atos administrativos de contingenciamento.

Em suma, a despeito de haver parâmetros jurídicos para a aplicação do contingenciamento, o que se verifica é uma prática desvinculada das exigências normativas, o que provoca efeitos negativos na execução do gasto público, tanto do ponto de vista quantitativo, quanto do ponto de vista qualitativo. É preciso, portanto, que as instituições e os mecanismos de controle atuem de forma mais contundente em face da prática do contingenciamento.

O que se pretende é que o Direito possa ser um vetor de desenvolvimento social e institucional, a fim de que os "processos de inclusão" superem os "processos de exclusão". Por isso que a realização deste estudo teve como pressuposto a ideia de que o Direito vigente pode conduzir à sociedade rumo a melhores condições. Ele não necessariamente legitima e reforça as desigualdades. O que faz com que o Direito seja hegemônico é o uso específico que as classes e grupos dominantes lhes dão, como menciona Boaventura de Sousa Santos.

Especificamente quanto ao tema analisado, sugere-se que uma aplicação do contingenciamento dentro de seus limites e parâmetros jurídicos é um passo importante para melhorar a gestão dos recursos públicos, especialmente da perspectiva do planejamento, da transparência, da legitimidade democrática, do controle e da consolidação dos direitos sociais. Tais aspectos são justamente objetivos e valores do Direito Financeiro, cuja concretização encontra, como um dos obstáculos, a aplicação 
ilimitada do contingenciamento. Se a melhor aplicação do contingenciamento não resolve todos os problemas, certamente provocará avanços na gestão dos gastos públicos. Não é uma solução simples, até porque, retornando ao sociólogo português "enfrentamos problemas modernos para os quais não existem soluções modernas".

Nessa linha, as propostas devem ser movimentadas também por maior participação democrática, como já ocorrem as pressões pela melhor aplicação dos recursos públicos, pela realização de políticas públicas no âmbito dos direitos sociais, pela transparência na gestão dos recursos - temas que perpassam o contingenciamento. É certo, e isso não se esqueceu, a implementação de todos esses anseios custa e precisa ser financiado. É esse financiamento que não se pode deixar de discutir - financiamento e aplicação dos recursos ou Direito Tributário e Direito Financeiro:

Como o Direito Financeiro suportará a pressão do Estado Social e de todas suas promessas, se o Direito Tributário não der respostas adequadas para sua implementação? Todos voltaremos a cuidar de nossos jardins, internos a nossos lares, deixando a praça, o espaço público, abandonado? (...) É imprescindível que seja realizado o equilíbrio entre o espaço do jardim e da praça, do âmbito privado e do público, do Direito Financeiro e do Direito Tributário, de forma dinâmica, permitindo que o Estado Social cumpra suas promessas de construção de uma sociedade livre, justa e solidária - palavras que não podem constituir-se em um Cavalo de Tróia para a manutenção infinda do status quo, postergando a plenitude da dignidade da pessoa humana. ${ }^{374}$

São essas algumas das discussões que se pretendeu trazer. São essas as perspectivas do que se espera do Direito Financeiro, cuja concretização deve ser continuamente perseguida. O trabalho acadêmico na área do Direito Financeiro terá maior sucesso se conseguir, a partir da tradução de dados e dos estudos relativos às finanças públicas, trazer para a praça e para o espaço público, o debate sobre a melhor aplicação dos recursos que, consequentemente, podem levar à construção de uma sociedade mais livre, justa e solidária.

\footnotetext{
${ }^{374}$ SCAFF, Fernando Facury. O Jardim e a Praça ou a Dignidade Humana e o Direito Tributário e Financeiro. In: Heleno Taveira Tôrres. (Org.). Direito e Poder - Nas Instituições do Público e do Privado Contemporâneos - Estudos em Homenagem a Nelson Saldanha. São Paulo: Manole, 2005, p. 556.
} 


\section{REFERÊNCIAS BIBLIOGRÁFICAS}

ALMEIDA, Carlos Otávio Ferreira de. Planejamento Financeiro Responsável. In CONTI, José Maurício; SCAFF, Fernando Facury (coord.). Orçamentos Públicos e Direito Financeiro. São Paulo: Editora Revista dos Tribunais, 2011.

ALMEIDA, Mansueto; MANOEL, Alexandre; REBOUÇAS, Helder. "Os impasses do contingenciamento”. Valor Econômico. São Paulo, 2 de março de 2012.

ALTHUSSER, Louis. Ideologia e aparelhos ideológicos do Estado. $3^{\mathrm{a}}$ ed. Lisboa: Presenca, 1980.

ALVES, Gustavo Henrique Tardelli. $O$ orçamento federal entre a realidade e a ficção: as armadilhas à transparência da despesa pública no Brasil. Monografia (especialização Curso de Orçamento Público). Instituto Serzedello Corrêa (ISC), 2012.

ARVATE, Paulo Roberto. Instituições e resultados fiscais do governo federal. In BIDERMAN, Ciro; ARVATE, Paulo (orgs.). Economia do Setor Público no Brasil. Rio de Janeiro: Elsevier, 2004.

ASSONI FILHO. Sérgio. Transparência fiscal e democracia. Porto Alegre: Núria Fabris Ed., 2009.

ÁVILA. Humberto. Teoria dos princípios: da definição à aplicação dos princípios jurídicos. $4^{\mathrm{a}}$ ed. São Paulo: Editora Malheiros, 2005.

AVRITZER, Leonardo. Modelos de deliberação democrática: uma análise do orçamento participativo no Brasil. In: SANTOS, Boaventura de Sousa (org.). Democratizar a democracia: os caminhos da democracia participativa. Rio de Janeiro, Civilização Brasileira, 2002.

BANDEIRA DE MELLO, Celso Antônio. Curso de Direito Administrativo. 20a edição. São Paulo: Malheiros, 2006.

BARROS, Maurício. Orçamento e Discricionariedade. In CONTI, José Maurício; SCAFF, Fernando Facury (coord.). Orçamentos Públicos e Direito Financeiro. São Paulo: Editora Revista dos Tribunais, 2011.

BERCOVICI, Gilberto; MASSONETTO, Luís Fernando. A Constituição Dirigente Invertida: A Blindagem da Constituição Financeira e a Agonia da Constituição 
Econômica. Boletim da Faculdade de Direito - Universidade de Coimbra. Suplemento. Coimbra, Portugal, v. XLIX, p. 57-77, 2006.

BEREIJO, Alvaro R. Estudio preliminar. In LABAND, Paul. Derecho presupuestario. Madrid: Instituto de Estudios Fiscales, 1979.

BEZERRA, Marcos O. Em nome das "bases”. Política, favor e dependência pessoal. Rio de Janeiro: Relume-Dumará, 1999.

BONAVIDES, Paulo. Curso de Direito Constitucional. 25 $5^{\mathrm{a}}$ ed. São Paulo: Malheiros, 2010.

BRASIL. Ministério do Desenvolvimento Social e Combate à Fome. Relatório de Gestão 2012 - Brasília, DF: MDS; Secretaria Nacional de Assistência Social, 2013. Disponível em

https://contas.tcu.gov.br/econtrole/ObterDocumentoSisdoc? codArqCatalogado=593152 0\&seAbrirDocNoBrowser=1. Acesso em 19/02/2014.

BRASIL. Ministério do Planejamento, Orçamento e Gestão. "Classificações Orçamentárias". Disponível em http://www.planejamento.gov.br/secretaria.asp?cat=51\&sub=130\&sec=8. Acesso em $10 / 06 / 2012$

. Ministério do Planejamento, Orçamento em Gestão. Informações Orçamentárias. Desvinculação das Receitas da União. Disponível em http://www.planejamento.gov.br/editoria.asp?p=imprensa\&ler=t478. Acesso em 24/03/2014.

- Ministério do Planejamento, Orçamento e Gestão. Secretaria do Orçamento Federal. Perguntas Frequentes. O que é contingenciamento?. Disponível em http://www.orcamentofederal.gov.br/perguntasfrequentes/4.como-faco-para-mecadastrar-no-curso-de-orcamento-publico-da-escola-virtual-sof. Acesso em 24/03/2014. 
BRASIL. Ministério do Planejamento, Orçamento e Gestão. Secretaria de Orçamento Federal. Manual técnico de orçamento MTO. Edição 2014. Brasília, 2013, p. 71. Disponível em http://www.orcamentofederal.gov.br/informacoesorcamentarias/manual-tecnico/MTO_2014.pdf. Acesso em 04/06/2014.

BRASIL. Ministério do Turismo. Relatório de Gestão 2012 - Brasília, DF. Secretaria Nacional de Políticas de Turismo, 2013. Disponível em https://contas.tcu.gov.br/econtrole/ObterDocumentoSisdoc? $\operatorname{codArqCatalogado=593044}$ 9\&seAbrirDocNoBrowser=1. Acesso em 19/02/2014. - Ministério do Turismo. Relatório de Gestão 2012 -- Brasília, DF. Secretaria $\begin{array}{llll}\text { Executivo, } & 2013 . & \text { Disponível }\end{array}$ https://contas.tcu.gov.br/econtrole/ObterDocumentoSisdoc?codArqCatalogado=593156 2\&seAbrirDocNoBrowser=1. Acesso em 19/02/2014

BRASIL. Secretaria do Tesouro Nacional. Metodologia de Cálculo do Superávit Primário. Disponível em http://www3.tesouro.fazenda.gov.br/hp/downloads/resultado/mnf_gv_central.pdf. Acesso em 31/05/2014.

BRASIL. Senado Federal. Glossário do Portal do Orçamento. Disponível em http://www9.senado.gov.br/portal/page/portal/orcamento_senado/Glossario. Acesso em 28 de maio 2012. . Senado Federal. Comissão Diretora. Parecer no 1.265/2013. Anexo. Redação, para o segundo turno, da Proposta de Emenda à Constituição no $22 \mathrm{~A}$, de $2000\left(\mathrm{n}^{\circ} 565\right.$, de 2006, na Câmara dos Deputados). Disponível em http://legis.senado.leg.br/mateweb/arquivos/mate-pdf/140049.pdf. Acesso em $25 / 11 / 2013$. 
. Senado Federal. Projeto de Lei do Senado n ${ }^{\circ} 229$, de 2009. Disponível em http://www.senado.gov.br/atividade/materia/detalhes.asp?p_cod_mate=91341. Acesso em 01/06/2013.

BRASIL. Câmara dos Deputados. Comissão Especial destinada a proferir parecer à proposta de Emenda à Constituição no 565-A, DE 2006, do Senado Federal. Emenda Substitutiva Global (Do Sr. Domingo Sávio e Outros). Justificativa. Disponível em http://www.camara.gov.br/proposicoesWeb/prop_mostrarintegra;jsessionid=3E2ADA8 0F8FF4F0E660BD611B6DF14EE.node1? codteor=1096674\&filename=EMC+18/2013 +PEC56506+\%3D\%3E+PEC+565/2006. Acesso em 24/03/2014.

BRASIL. Superior Tribunal de Justiça. Corte Especial. Agravo Regimental na Suspensão de Liminar de Sentença n ${ }^{\circ}$ 1.120/SP. Relator Ministro Cesar Asfor Rocha. Julgamento em 18/08/2010.

. Superior Tribunal de Justiça. Primeira Turma. Recurso em Mandado de Segurança n 32.521/RO. Relator Ministro Benedito Gonçalves. Julgado em 01/09/2011.

BRASIL. Supremo Tribunal Federal. Pleno. ADI 691 MC/TO. Relator Ministro Sepúlveda Pertence. Julgamento em 22/04/1992.

. Supremo Tribunal Federal. Pleno. Ação Direta de Inconstitucionalidade nº 939/DF. Relator Ministro Sydney Sanches. Julgamento em 15/12/1993.

—. Supremo Tribunal Federal. Pleno. Ação Direta de Inconstitucionalidade nº 1640 QO. Relator Ministro Sydney Sanches. Julgamento em 12/02/1998. . Supremo Tribunal Federal. Ação Direta de Inconstitucionalidade. Medida Cautelar. ADI n ${ }^{\circ}$ 2.153/ES. Relator Ministro Ilmar Galvão. Julgamento em 16/08/2000. - Supremo Tribunal Federal. Pleno. Ação Direta de Inconstitucionalidade $\mathrm{n}^{\circ}$ 2.925/DF. Relatora Ministra Ellen Gracie. Relator para acórdão Ministro Marco Aurélio. Julgamento em 19/12/2003. 
- Supremo Tribunal Federal, Pleno, Ação Direta de Inconstitucionalidade $\mathrm{n}^{\circ}$

3.401/SP. Relator Ministro Gilmar Mendes. Julgamento em 26/04/2006.

. Supremo Tribunal Federal. Pleno. Medida Cautelar na Ação Direta de

Inconstitucionalidade $n^{\circ}$ 2.238-5/DF. Relator Ministro Ilmar Galvão. Relator para Acórdão Ministro Carlos Britto. Julgamento em 09/08/2007.

- Supremo Tribunal Federal. Pleno. Ação Direta de Inconstitucionalidade $\mathrm{n}^{\circ}$

4.048/DF. Relator Ministro Gilmar Mendes. Julgamento em 14/05/2008.

_. Supremo Tribunal Federal. Primeira Turma. Recurso Extraordinário no 351.750/RJ.

Relator Ministro Marco Aurélio. Relator para acórdão Ministro Carlos Britto. Julgamento em 17/03/2009.

- Supremo Tribunal Federal. Segunda Turma. Agravo Regimental no Recurso

Extraordinário n ${ }^{o}$ 581.352/AM. Relator Ministro Celso de Mello. Julgamento em $29 / 10 / 2013$

BRASIL. Tribunal de Contas da União. Plenário. Processo nº 012.781/2004-2. Acórdão no 183/2005. Relator Ministro Benjamin Zymler. Julgamento em 02/03/2005.

. Tribunal de Contas da União. Plenário. Processo no $013.811 / 2010-0$. Acórdão $n^{\circ}$

1143/2011. Relator Aroldo Cedraz. Julgamento em 11/05/2011.

. Tribunal de Contas da União. Plenário. Processo TC 032.114/2013-0. Acórdão no

46/2014. Relator Valmir Campelo. Julgado em 22/01/2014.

_. Tribunal de Contas da União. Convênios e outros repasses. $4^{\mathrm{a}}$ Ed. Brasília:

Secretaria-Geral de Controle Externo, 2013. Disponível em http://portal2.tcu.gov.br/portal/pls/portal/docs/2548956.PDF. Acesso em 04/06/2014.

BRASIL. Tribunal Regional Federal da $1^{\text {a }}$ Região. Quinta Turma. Agravo de Instrumento

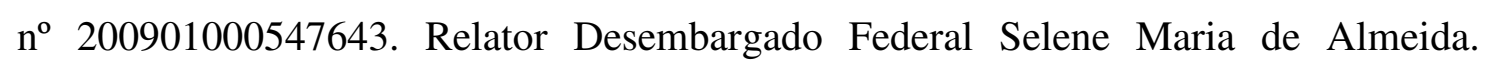
Julgado em 03/11/2010. 
. Tribunal Regional Federal da $1^{\mathrm{a}}$ Região. Corte Especial. Agravo Regimental na

Suspensão de Segurança nº 200201000263734. Relator Desembargador Federal Catão Alves. Julgado em 19/09/2002.

— Tribunal Regional Federal da $1^{\mathrm{a}}$ Região. Sexta Turma. Apelação Cível $\mathrm{n}^{\mathrm{o}}$ 199901000869084. Relator Desembargador Daniel Paes Ribeiro. Julgado em 24/06/2002.

BRASIL. Tribunal Regional Federal da $2^{\mathrm{a}}$ Região. Primeira Seção. Embargos Infringentes em Apelação Cível nº 9702322464. Relator Desembargadora Federal Julieta Lidia Lunz. Julgado em 13/06/2002.

BRASIL. Tribunal Regional Federal da $5^{\mathrm{a}}$ Região. Quarta Turma. Apelação Cível $\mathrm{n}^{\mathrm{o}}$ 200905000342949. Relator Desembargador Federal Frederico Dantas. Julgado em $15 / 12 / 2009$.

. Tribunal Regional Federal da $5^{\mathrm{a}}$ Região. Terceira Turma. Apelação Cível $\mathrm{n}^{\mathrm{o}}$ 200405000100087. Relator Desembargador Federal Paulo Roberto de Oliveira Lima. Julgado em 22/11/2007.

- Tribunal Regional Federal da 5a Região. Primeira Turma. Apelação Cível no 200605000581359. Relator Desembargador Federal Francisco Wildo. Julgado em 09/08/2007.

CABRAL, Nazaré da Costa. Programa e decisão orçamental: da racionalidade das decisões orçamentais à racionalidade econômica. Coimbra: Almedina, 2008.

CAMPOS, Francisco. Orçamento - Natureza jurídica. In: Revista de Direito Administrativo 71/324 jan./mar. 1963.

CANOTILHO, J. J. Gomes. Constituição Dirigente e vinculação do legislador. $2^{\mathrm{a}}$ ed. Coimbra: Coimbra Editora, 2001. . Direito Constitucional e Teoria da Constituição. $7^{\mathrm{a}}$ ed. Coimbra: Almedina, 2003. . Estudos sobre direitos fundamentais. Coimbra: Coimbra Editora, 2004. 
CARVALHO, André Castro. Vinculação de Receitas Públicas. São Paulo: Quartier Latin, 2010.

. Direito Constitucional Financeiro e Direito Orçamentário Substantivo. In CONTI, José Maurício; SCAFF, Fernando Facury (coord.). Orçamentos Públicos e Direito Financeiro. São Paulo: Editora Revista dos Tribunais, 2011.

CATARINO, João Ricardo. Processo Orçamental e sustentabilidade das finanças públicas: o caso europeu. In SCAFF, Fernando Facury; CONTI, José Maurício. Orçamentos Públicos e Direito Financeiro. São Paulo: Editora Revista dos Tribunais, 2011.

CHAUÍ, Marilena. O que é ideologia. São Paulo: Brasiliense, 2004.

CHRISTOPOULOS, Basile; BASTOS, Frederico Silva. Administração Tributária Eficiente, Democracia e Desenvolvimento: experiências internacionais sobre índices de transparência fiscal e sua utilidade para o Brasil. Revista Discente Direito GV, v. 1, p. 011-30, 2012.

CHRISTOPOULOS, Basile. Controle de constitucionalidade de normas orçamentárias: o uso de argumentos consequencialistas nas decisões do Supremo Tribunal Federal. Tese de Doutorado. Faculdade de Direito da Universidade de São Paulo. São Paulo, 2014.

CINTRA, Antônio Carlos de Araújo. Motivo e Motivação do Ato Administrativo. São Paulo: Editora Revista dos Tribunais, 1979.

CONTI, José Maurício (coord.). Orçamentos Públicos. A Lei nº 4.320/64 comentada. $2^{\text {a }}$ ed. São Paulo: Editora Revista dos Tribunais, 2010.

CONTI, José Maurício. A autonomia Financeira do Poder Judiciário. São Paulo: MP Editora, 2006.

. Planejamento e Responsabilidade Fiscal. In SCAFF, Fernando Facury; CONTI, José Maurício. Lei de Responsabilidade Fiscal - 10 anos de Vigência - Questões Atuais. Florianópolis: Conceito Editorial, 2010.

Iniciativa Legislativa em matéria financeira. In SCAFF, Fernando Facury; CONTI, José Maurício. Orçamentos Públicos e Direito Financeiro. São Paulo: Editora Revista dos Tribunais, 2011. 
- Emendas ao Orçamento e o Desequilíbrio de poderes. Disponível em http://www.conjur.com.br/2012-jul-03/contas-vista-emendas-orcamento-desequilibriopoderes. Acesso em 07/05/2013.

CORTI, Horacio. Derechos fundamentales y presupuesto publico. In CONTI, José Maurício; SCAFF, Fernando Facury (coord.). Orçamentos Públicos e Direito Financeiro. São Paulo: Editora Revista dos Tribunais, 2011.

Derecho Financiero. Buenos Aires: Alberto Perrot, 1997.

COUTINHO, Diogo R. O direito nas políticas públicas. P. 10. Artigo disponível em http://www.cebrap.org.br/v2/files/upload/biblioteca_virtual/item_766/14_05_12_16O_ direito_nas_politicas_publicas_FINAL.pdf. Acesso em 30/03/2014.

DALLARI. Adilson Abreu. Orçamento Impositivo. In CONTI, José Maurício; SCAFF, Fernando Facury (coord.). Orçamentos Públicos e Direito Financeiro. São Paulo: Editora Revista dos Tribunais, 2011.

DALLAVERDE, Alexandra Katia. As relações entre os poderes na gestão das Finanças Públicas. Porto Alegre: Nuria Fabris Editora, 2013.

DEBRLI, Felipe. A aplicabilidade do princípio da proibição do retrocesso social no Direito Brasileiro. In SOUZA NETO, Claudio Pereira; SARMENTO, Daniel (coords.). Direitos Sociais: Fundamentos, Judicialização e Direitos Sociais em espécie. Rio de Janeiro: Editora Lumen Juris, 2010.

DI PIETRO. Maria Sylvia Zanell. Direito Administrativo. 23ª ed. São Paulo: Atlas, 2010.

DUARTE, Tiago. A lei por detrás do orçamento: a questão constitucional da Lei do Orçamento. Coimbra: Almedina, 2007.

ENGELS, Friedrich. Carta a Starkenburg, de 2 de janeiro de 1984. Disponível em http://www.scientific-socialism.de/FundamentosCartasMarxEngels250194.htm. Acesso em $07 / 12 / 2012$.

FOUCAULT, Michel. A verdade e as formas jurídicas. Rio de Janeiro: PUC, 2008.

FREUD, Sigmund. O mal-estar na cultura. Tradução de Renato Zwick; revisão técnica e prefácio de Márcio Seligmann-Silva; Ensaio Bibliográfico de PauloEndo e Edson Sousa. Porto Alegre: L\&PM, 2010.

GASPARINI, Diogenes. Direito Administrativo. 12ª edição. São Paulo: Saraiva, 2007. 
HARNECKER, Marta. Os conceitos elementais do materialismo histórico. Apresentação de Louis Althusser. Santiago, 1973.

HOBBES, Thomas. Leviatã. Coleção Os Pensadores. São Paulo: Editora Nova Cultura, 2010.

HUME, David. Tratado da natureza humana - uma tentativa de introduzir o método experimental de raciocínio nos assuntos morais. São Paulo: Editora UNESP, 2005.

GOMES, Claudia Cristina Aires. O impacto da edição de medidas provisórias no orçamento público. Monografia (especialização). Instituto Serzedello Corrêa, do Tribunal de Contas da União, Centro de Formação, Treinamento e Aperfeiçoamento (Cefor), da Câmara dos Deputados e Universidade do Legislativo Brasileiro (Unilegis), do Senado Federal. Curso de Especialização em Orçamento Público, 2008.

GONTIJO, Vander. Orçamento impositivo, contingenciamento e transparência. Cadernos ASLEGIS. Janeiro/Abril, 2010. Disponível em http://www.aslegis.org.br/aslegis/images/stories/PDF/orcamento-impositivo.pdf

GRAU, Eros Roberto. A ordem econômica na Constituição de 1988, 10ª ed. São Paulo; Malheiros, 2005.

HABER NETO, Michel. A tributação e o financiamento do direito à saúde no Brasil. Dissertação de Mestrado em Direito. Faculdade de Direito da Universidade de São Paulo. São Paulo, 2012.

HESSE, Konrad. A Força Normativa da Constituição. Trad. de Gilmar Ferreira Mendes. Porto Alegre: Sergio Antonio Fabris Editor, 1991.

HOLMES, Stephen; SUNSTEIN, Cass R. The Cost of Rights - why liberty depend on taxes. New York: W.W.Norton \& Company, 1999.

LAPATZA, Jose Ferreiro. Derecho Financiero y Ordenamiento Jurídico: una aproximación metodologica al estudio del DerechoFinanciero. In: RDP ${ }^{\circ} 18$, out-dez. 1971.

LOCHAGIN, Gabriel Loretto. A flexibilidade da execução orçamentária. Dissertação de Mestrado em Direito. Faculdade de Direito da Universidade de São Paulo. São Paulo, 2012. 
MACHADO, Antônio Alberto. Ensino jurídico e mudança social. $2^{\mathrm{a}}$ ed. São Paulo: Expressão Popular, 2009.

MARTINS, Marcelo Guerra. As vinculações das receitas públicas no orçamento. A Desvinculação das Receitas da União (DRU). As contribuições e a referibilidade. In CONTI, J. Maurício; SCAFF, Fernando F. (coords.). Orçamentos públicos e direito financeiro. São Paulo: Revista dos Tribunais, 2011.

MARX, Karl. Crítica da filosofia do direito de Hegel. Trad. de Rubens Enderle e Leonardo de Deus. São Paulo: Boitempo, 2005.

MEIRELLES, Hely Lopes. Direito administrative municipal brasileiro. São Paulo: RT, 1989.

MELO, Carlos Antonio de Almeida. Mecanismos de proteção e concretização constitucional: proposta de uma ação de concretização da Constituição. In SCAFF, Fernando Facury (org.). Constitucionalizando Direitos: 15 anos da Constituição Brasileira de 1988. Rio de Janeiro: Renovar, 2003.

MENDES, Marcos J. Sistema orçamentário brasileiro: planejamento, equilíbrio fiscal e qualidade do gasto público. Texto para discussão 39. Brasília: Consultoria Legislativa do Senado Federal, 2008.

MENDONÇA, Eduardo Bastos Furtado de. Constitucionalização das Finanças Públicas no Brasil. Rio de Janeiro: Renovar, 2010.

MORAES, Cesar de. Breves Considerações sobre deficiências estruturais do sistema orçamentário brasileiro. In CONTI, José Maurício; SCAFF, Fernando Facury (coord.). Orçamentos Públicos e Direito Financeiro. São Paulo: Editora Revista dos Tribunais, 2011.

NEVES, Marcelo. Luhmann, Habermas e o Estado de Direito. In: Revista de Cultura e Política, no 37, 1996.

A Constitucionalização Simbólica. São Paulo: WMF Martins Fontes, 2007.

NUNES, Selene Peres. Os 10 anos da LRF e o Projeto de Lei da Qualidade Fiscal. In Cadernos da Controladoria, Ano X, no 02. Rio de Janeiro, 2010. Disponível em http://www7.rio.rj.gov.br/cgm/comunicacao/publicacoes/cadernos/edicoes/2010_09/an exos/caderno_09_2010.pdf. 
OCTAVIANI. Alessandro. A bênção de Hamilton na semiperiferia: ordem econômicosocial e os juros da dívida pública interna. In CONTI, José Maurício; SCAFF, Fernando Facury (coord.). Orçamentos Públicos e Direito Financeiro. São Paulo: Editora Revista dos Tribunais, 2011.

OLIVEIRA, Regis Fernandes de. Curso de direito financeiro. $4^{\mathrm{a}}$ ed., ver., atual e ampliada. São Paulo: Revista dos Tribunais, 2011. . Gastos públicos. São Paulo: Editora Revista dos Tribunais, 2012,

PINHEIRO. Luis Felipe Valerim. Rumo ao Orçamento Impositivo: a delimitaçào das ações administrativas pelas leis orçamentárias. In CONTI, José Maurício; SCAFF, Fernando Facury (coord.). Orçamentos Públicos e Direito Financeiro. São Paulo: Editora Revista dos Tribunais, 2011.

PINTO, Élida Graziane. Financiamento de Direitos Fundamentais: políticas públicas vinculadas, estabilização monetária e conflito distributivo no orçamento da União do pós-Plano Real. Belo Horizonte: Editora O Lutador, 2010.

. Discricionariedade, contingenciamento e controle orçamentário. In: Revista de Gestão e Tecnologia. V. 6, $\mathrm{n}^{\mathrm{o}}$ 2. 2006. Disponível em http://revistagt.fpl.edu.br/get/search/authors/view?firstName=\%C3\%89lida\%20Grazian e\&middleName=\&lastName=Pinto\&affiliation=\&country=. Acesso em 05/05/2013.

PONTES, João Batista Pontes; PEDERIVA, João Henrique. Contas Prestadas pelo Presidente da República: Apreciação do Congresso Nacional. Texto para discussão 14. Brasília: Consultoria Legislativa do Senado Federal, 2004, p. 08. Disponível em http://www12.senado.gov.br/publicacoes/estudos-legislativos/tipos-de-estudos/textospara-discussao/td-14-contas-prestadas-pelo-presidente-da-republica-apreciacao-docongresso-nacional. Acesso em 11/03/2014.

REZENDE, Fernando; CUNHA, Armando. O Orçamento Público e a transição do poder. Rio de Janeiro: FGV, 2003.

ROCHA, Francisco Sérgio Silva. Orçamento e Planejamento: a relação de necessidade entre as normas do sistema orçamentário. In CONTI, José Maurício; SCAFF, Fernando Facury (coord.). Orçamentos Públicos e Direito Financeiro. São Paulo: Editora Revista dos Tribunais, 2011, pp. 729-749. 
SABBAG. Cesar de Moraes. Breves Considerações sobre deficiências estruturais do sistema orçamentário brasileiro. In CONTI, José Maurício; SCAFF, Fernando Facury (coord.). Orçamentos Públicos e Direito Financeiro. São Paulo: Editora Revista dos Tribunais, 2011.

SADECK, Francisco; GERIN, Alvaro; VALLE, Bruno. Contingenciamento: necessidade tributária ou instrumento da política econômica. Nota Tecnica $\mathrm{n}^{\circ}$ 98. INESC, Maio/2005. Disponível em: http://www.inesc.org.br. Acesso em 10/03/2014.

SANTI, Eurico Marcos Diniz De; PISCITELLI, Tathiane dos Santos. Análise da destinação dos recursos da CPMF no período de 2001 a 2006. In: Cadernos Direito GV, v. 05, p. 09-31, 2008.

SANTOS, Boaventura de Sousa. Orçamento participativo em Porto Alegre: para uma democracia redistributiva. In: SANTOS, Boaventura de Sousa (org.). Democratizar a democracia: os caminhos da democracia participativa. Rio de Janeiro, Civilização Brasileira, 2002.

. Poderá o direito ser emancipatório? In: Revista Crítica de Ciências Sociais, 65, Maio de 2003: 3-76. Disponível em http://www.boaventuradesousasantos.pt/media/pdfs/podera_o_direito_ser_emancipator io_RCCS65.PDF. Acesso em 21/03/2014.

SARLET, Ingo Wolfgang. A Eficácia dos Direitos Fundamentais. Porto Alegre: Livraria do Advogado, 2001.

- Proibição de retrocesso, dignidade da pessoa humana e direitos sociais: manifestação de um constitucionalismo dirigente possível. In: Revista Eletrônica sobre a Reforma do Estado (RERE), Salvador, Instituto Brasileiro de Direito Público, no 15 , setembro/outubro/novembro de 2008, p. 08. Disponível em www.direitodoestado.com.br/rere.asp. Acesso em 28/02/2014.

SCAFF, Fernando Facury; ROCHA, Francisco Sergio Silva. Equilíbrio Orçamentário e Sustentabilidade Financeira. In Revista dos Tribunais, vol. 925, p. 175, Nov / 2012. Thomsom Reuters, 2012.

SCAFF, Fernando Facury; MAUÉS, Antonio G. Moreira. Justiça Constitucional e Tributação. São Paulo: Dialética, 2005. 
SCAFF, Fernando Facury. Para além dos direitos fundamentais do contribuinte: o STF e a vinculação das contribuições. In: Luís Eduardo Schoueri. (Org.). Direito Tributário Homenagem a Alcides Jorge Costa. São Paulo: QuartierLatin, 2003, v. 2, p. 1125-1146 . Constituição Econômica Brasileira em seus 15 anos. Revista de Direito Público da Economia - RDPE, Belo Horizonte, v. 3, jul / set, p. 67-101, 2003.

Direitos Humanos e a Desvinculação das Receitas da União - DRU. In: Octávio Campos Fischer. (Org.). Tributos e Direitos Fundamentais. 1a ed. São Paulo: Dialética, 2004, p. 63-79.

- Como a Sociedade Financia o Estado para a Implementação dos Direitos Humanos ?. In COUTINHO, Jacinto Nelson de Miranda; MORAIS, Jose Luis Bolzan de; STRECK, Lenio Luiz. (Org.). Estudos Constitucionais. São Paulo: Renovar, 2007, v. 1, p. 71-100.

A efetivação dos direitos sociais no Brasil: garantias constitucionais de financiamento e judicialização. In: Fernando Facury Scaff; Roberto Romboli; Miguel Revenga. (Org.). A Eficácia dos Direitos Sociais - I Jornada Internacional de Direito Constitucional Brasil/Espanha/Itália. 1 a ed. São Paulo: QuartierLatin, 2009, v. 1, p. 2253.

O Jardim e a Praça ou a Dignidade Humana e o Direito Tributário e Financeiro. In: Heleno Taveira Tôrres. (Org.). Direito e Poder - Nas Instituições do Público e do Privado Contemporâneos - Estudos em Homenagem a Nelson Saldanha. São Paulo: Manole, 2005.

Direito à saúde e os tribunais. In: NUNES, António José Avelãs; SCAFF, Fernando Facury. Os tribunais e o direito à saúde. Porto Alegre: Editora Livraria do Advogado, 2011.

Direitos Fundamentais e Orçamento: despesas sigilosas e o direito à verdade.

In CONTI, J. Maurício; SCAFF, Fernando F. (coords.). Orçamentos públicos e direito financeiro. São Paulo: Revista dos Tribunais, 2011, pp. 215-231.

SCHOPENHAUER, Arthur. O mundo como vontade e representação. Trad. M. F. Sá Correia. Rio de Janeiro: Contraponto, 2001.

SCHWARTSMAN, Alexandre. O orçamento e o vento. Folha de São Paulo. Artigo disponível 
http://www1.folha.uol.com.br/colunas/alexandreschwartsman/2014/02/1417921-oorcamento-e-o-vento.shtml. Acesso em 12/03/2014.

SEGUNDO, Hugo de Brito Machado. Contribuições e Federalismo. São Paulo: Dialética, 2005.

SILVA. Virgílio Afonso. O Judiciário e as políticas públicas: entre transformação social e obstáculo à realização dos direitos sociais. In: SOUZA NETO, Cláudio Pereira de; SARMENTO; Daniel. Direitos sociais: fundamentação, judicialização e direitos sociais em espécies. Rio de Janeiro: Lumen Juris, 2008.

SOARES, Onildo Rodrigues. Os Impactos que decretos de contingenciamento causam ao desempenho das agências reguladoras federais. Trabalho de Pós-Gradução. PPGA. Universidade de Brasília. 2009.

SPINK, Peter. Informação, transparência e cidadania - o controle da execução orçamentária pelo cidadão. In Cadernos de Gestão Pública e Cidadania, vol. 23. Junho de 2003

TAVARES, André Ramos. Curso de direito constitucional. São Paulo: Saraiva, 2002.

TAVEIRA, Christiano de Oliveira; MARÇAL, Thaís Boia. Proibição do retrocesso social e orçamento: em busca de uma relação harmônica. Revista de Direito Administrativo, Rio de Janeiro, v. 264, set./dez. 2013.

TORRES, Heleno Taveira. Teoria da Constituição Financeira. Tese apresentada ao Concurso de Títulos e Provas para o cargo de Professor Titular de Direito Financeiro. Faculdade de Direito da Universidade de São Paulo. São Paulo, 2014.

VALDÉS, Ernesto Garzón. Introdución. In: El derecho como objeto e instrumento de transformación. Seminario en Latinoamerica de Teoria Constitucional e Politica (SELA 2002). Buenos Aires: Editores del Puerto, 2003

VESELY, Thiago Andrigo. Emendas orçamentárias como instrumento de coordenação no legislativo brasileiro. Monografia apresentada ao Programa de Pós-Graduação do Centro de Formação, Treinamento e Aperfeiçoamento da Câmara dos Deputados/CEFOR como parte da avaliação do Curso de Especialização em Política e Representação Parlamentar. Brasília, 2012.

XAVIER. Antonio Lobo. Orçamento como lei: contributo para a compreensão de algumas especificidades do Direito Orçamental Português. Coimbra, 1990. 
WEBER, Max. Economia e Sociedade. Volume 01. Brasília: Editora UnB, 1991.

ZANCHIM, Kleber Luiz. Arts. 12 a 21. In CONTI, José Maurício (coord.). Orçamentos

Públicos. A Lei $n^{o} 4.320 / 64$ comentada. $2^{\text {a }}$ ed. São Paulo: Editora Revista dos Tribunais, 2010. 


\section{REFERÊNCIAS - NOTÍCIAS VEICULADAS EM MEIOS DE COMUNICAÇÃO}

BELAT, Thaís. Programa de violência contra mulher aplica apenas $31 \%$ dos recursos de 2013. Portal Contas Abertas. Disponível em http://www.contasabertas.com.br/website/arquivos/7796. Acesso em 24/03/2014.

DIÁRIO REGIONAL. Câmara de São Caetano aprova Orçamento para 2013 de R\$ 1,035 bi. Portal do Diário Regional. Disponível em: http://www.diarioregional.com.br/2012/11/28/sua-regiao/politica-abc/politica-saocaetano-do-sul/camara-de-sao-caetano-aprova-orcamento-para-2013-de-r-1035-bi/. Acesso em 08/12/2012.

DUTRA, Marina. Contingenciamento na Agricultura prejudica "Defesa Agropecuária". Portal Contas Abertas. Disponível em http://www.contasabertas.com.br/website/arquivos/6599. Acesso em 24/03/2014.

ESTADO DE MINAS. Dinheiro da saúde só no papel. Portal Contas Abertas. Disponível em http://www.contasabertas.com.br/website/arquivos/sobrecontas/dinheiro-da-saudeso-no-papel. Acesso em 24/03/2014.

FERREIRA, João Sette Whitaker. Apostila didática: alguns elementos de reflexão sobre conceitos básicos de planejamento urbano e urbano-regional. Disponível em: http://www.fau.usp.br/docentes/depprojeto/j_whitaker/aposplan.html. Acesso em $08 / 12 / 2012$.

FOLHA DE S PAULO. Contingenciamento Fatal. Disponível em http://www1.folha.uol.com.br/fsp/opiniao/fz3105200503.htm. Acesso em 05/05/2013.

JUNQUEIRA, Caio. Governo prepara ação no STF contra orçamento impositivo. Valor Econômico. Disponível em http://www.valor.com.br/brasil/3166018/governo-preparaacao-no-stf-contra-orcamento-impositivo. Acesso em 25/03/2014.

LUGULO, Marise. Adoção do orçamento impositivo não é inconstitucional, afirma juiz. Portal da Câmara dos Deputados. Disponível em http://www2.camara.leg.br/camaranoticias/noticias/ADMINISTRACAOPUBLICA/444230-ADOCAO-DO-ORCAMENTO-IMPOSITIVO-NAO-EINCONSTITUCIONAL,-AFIRMA-JUIZ.html. Acesso em 25/03/2014. 
MENEZES, Dielle. Secretaria de Políticas para Mulheres executou apenas $40 \%$ dos recursos de 2013. Portal Contas Abertas. Disponível em http://www.contasabertas.com.br/website/arquivos/7931. Acesso em 25/03/2014.

MENEZES, Dielle. Contingenciamento afeta programa para combate ao uso de drogas. Portal Contas Abertas. Disponível em http://www.contasabertas.com.br/website/arquivos/520. Acesso em 24/03/2014.

MENEZES, Dielle; DUTRA, Marina. Manifestações "cobram” R\$ 160 bilhões que deixaram de ser investidos em 10 anos. Portal Contas Abertas. Disponível em http://www.contasabertas.com.br/website/arquivos/552. Acesso em 24/03/2014.

PATU, Gustavo; COLON, Leandro. Folha de São Paulo. Governo faz liberação atípica de verna no dia de acordão na CPI. Disponível em http://www1.folha.uol.com.br/fsp/poder/44658-governo-fez-liberacao-atipica-de-verbano-dia-de-acordao-na-cpi.shtml. Acesso em 05/05/2013.

PEREIRA, Juvenal. Entenda como funciona o orçamento municipal. Portal da Câmara Municipal. Disponível em http://www.camara.sp.gov.br/index.php?option=com_content $\&$ view=article $\& i d=2670$ : conheca-o-orcamento-municipal-\&catid=65: materias-especiais $\&$ Itemid $=160 . \quad$ Acesso em 08/12/2012. 


\section{SITES CONSULTADOS}

www.contasabertas.com.br

www.jf.jus.br/juris/unificada

www.orcamentofederal.gov.br/informacoes-orcamentarias

www.planalto.gov.br/legislacao

www.planejamento.gov.br

www.stf.jus.br

www.stj.jus.br

www.tcu.gov.br

www.tesouro.fazenda.gov.br/pt/siafi

www9.senado.gov.br/portal/page/portal/orcamento_senado/SigaBrasil

www12.senado.gov.br/orcamento/loa 